UNIVERSIDADE DE SÃO PAULO

ESCOLA DE COMUNICAÇÕES E ARTES

DEPARTAMENTO DE COMUNICAÇÕES E ARTES

\title{
Revista Comunicação \& Educação - a emergência de uma interface entre duas áreas do conhecimento
}

Juliana Winkel Marques dos Santos

Dissertação apresentada ao Programa de Pós-Graduação em Ciências da Comunicação, Área de Concentração Teoria e Pesquisa em Comunicação, Linha de Pesquisa Estética e História da Comunicação, da Escola de Comunicações e Artes da Universidade de São Paulo, como exigência parcial para obtenção do título de Mestre em Ciências da Comunicação, sob a orientação da Profa. Dra. Maria Cristina Castilho Costa.

São Paulo

Agosto de 2012

Juliana Winkel Marques dos Santos 


\title{
Revista Comunicação \& Educação - a emergência de uma interface entre duas áreas do conhecimento
}

\author{
Juliana Winkel Marques dos Santos
}

Dissertação apresentada ao Programa de Pós-Graduação em Ciências da Comunicação, Área de Concentração Teoria e Pesquisa em Comunicação, Linha de Pesquisa Estética e História da Comunicação, da Escola de Comunicações e Artes da Universidade de São Paulo, como exigência parcial para obtenção do título de Mestre em Ciências da Comunicação, sob a orientação da Profa. Dra. Maria Cristina Castilho Costa. 
MEMBROS DA BANCA EXAMINADORA 
Dois anos e meio de estudos, pesquisas e discussões são capazes de provocar mudanças profundas na visão e na forma de pensar de um estudante e pesquisador. Descobre-se, então, o verdadeiro sentido subjacente às próprias escolhas: promover transformações em si mesmo e, em consequência, no mundo ao redor.

Agradeço, aqui, a todos os que foram fundamentais para que mais esse caminho pudesse ter início, se desenvolver e se concretizar. Aos meus pais Erika e Wilson, meus primeiros e mais importantes alicerces; a meu irmão André, como eles, presença imprescindível em cada passo da caminhada. A todos os meus familiares pelo apoio constante e presente.

A Carlos Cruz, Donato Medeiros e Silvio Toni, pelo incentivo aos primeiros passos desta etapa. Aos colegas e amigos de todos os dias na Associação Amigos do Guri: Aieda Freitas, Cauê Marchetti, Ceci Amorim, Marcelo Santana, Marcelo Bolzan e, em especial, a Monica Souza e Renata Truzzi, que tornaram possível, no cotidiano de nosso trabalho, que também este projeto seguisse adiante.

Àqueles sem cuja presença, apoio e amizade não haveria inspiração para prosseguir: Amanda Kartanas, Ana Luisa Néca, Ana Paula Coronato, Camila Conti, Celeste Toledo, Claudia Mello, Claudia Nascimento, Cyntia Tagliatelli, Fabiana Bettoni, Fernanda Favaro, Fernando Augusto, Francine Machado, Gabriela Oliveira, Lilian Nakashima, Luciano Favaro, Mara Romanin, Mariana Franchi, Marina Assis, Marina Segre, Milena Martinez, Nancy Passos, Paula Chiuratto, Paula Rodrigues, Rodrigo Fonseca, Rodrigo Masuda, Taís Coppini, Tatiana Dicenzo, Valquiria Boccato.

Aos colegas e amigos do curso de Mestrado e a outros que surgiram ao longo do caminho, contribuindo para que ele fosse realizado de forma mais rica e gratificante: Daniela Bertocchi, Larissa Barreto, Isabella Bruni, Paulo Lima.

A Antonio Muci, responsável pelas mais belas surpresas deste período. 
À equipe da revista Comunicação \& Educação e do Departamento de Comunicações e Artes da ECA - em especial Carolina Boros, Consuelo Ivo, Cristine Vargas, Jackeline Pithan, Kelly Sinhorini, Marcelo Gomes e Sandra Alonso Caixeta pela presença e apoio em todos os momentos, sem os quais não teria sido possível concluir este trabalho.

Aos professores das disciplinas realizadas durante o curso: Adilson Citelli, Alice Mitika Koshiyama, Ismar Soares e Maria Immacolata Vassalo de Lopes - e ainda às professoras Maria Aparecida Baccega e Ruth Ribas Itacarambi, por contribuírem com novas formas de ver e interpretar o mundo.

À minha orientadora, professora Maria Cristina Castilho Costa, por mais este período de enriquecimento pessoal, profissional e acadêmico no qual tive a oportunidade de aprender muito e sempre mais, sob todos os aspectos.

Que as transformações promovidas no pensamento possam se refletir em trabalho conjunto e realizações também no dia-a-dia. A todos, muito obrigada. 
$\mathrm{O}$ presente trabalho discute $\mathrm{o}$ surgimento, emergência e consolidação da interface entre a comunicação e a educação - seus processos, bases conceituais e aplicações - à luz da análise editorial da revista Comunicação \& Educação, publicação semestral dedicada à discussão desse tema, editada pela Escola de Comunicações e Artes da Universidade de São Paulo. Por meio do acompanhamento da trajetória da revista, pretende-se mostrar como se reflete, nesta, a própria evolução do campo de que trata, e que também ajuda a construir.

\section{Palavras-chave}

Comunicação; educação; análise editorial; cidadania; interface.

The current work discusses the appearance, emergence and consolidation of the interface between communication and education - its processes, conceptual basis and applications - in the light of the editorial analysis of the magazine Communication \& Education, a semiannual publication dedicated to the discussion of this subject, edited by the Arts and Communications School of São Paulo University. By following the magazine's trajectory, there is the intention to show how it reflects on it, the real evolution of the field it deals with, and that also helps to build it.

\section{Keywords}

Communication; education; editorial analysis; citizenship; interface. 


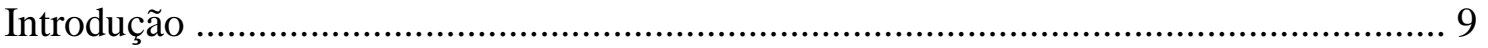

1. Objeto de Estudo: Revista Comunicação \& Educação .............................................. 12

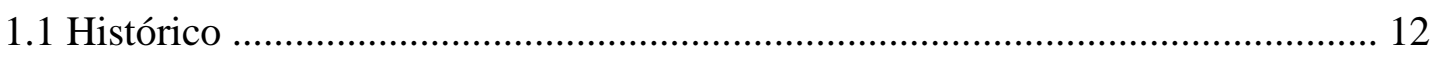

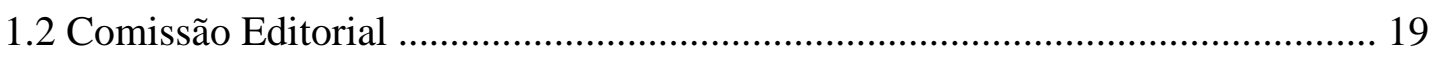

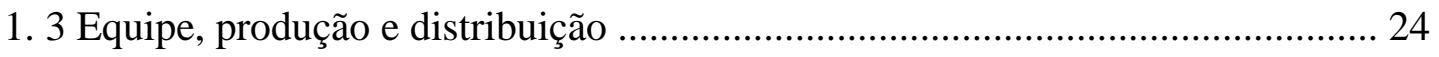

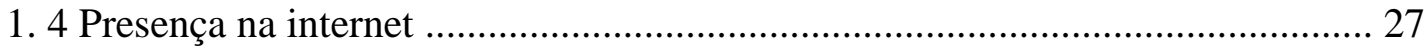

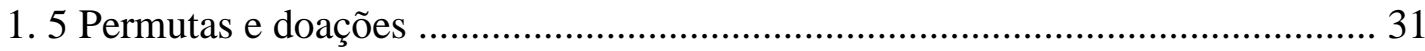

1. 6 Definição do perfil editorial ………………………………………………..... 35

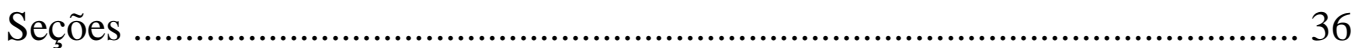

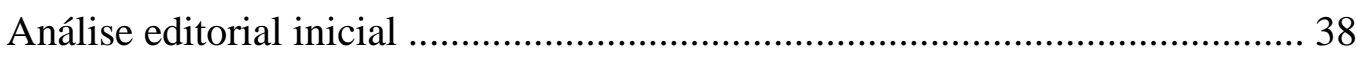

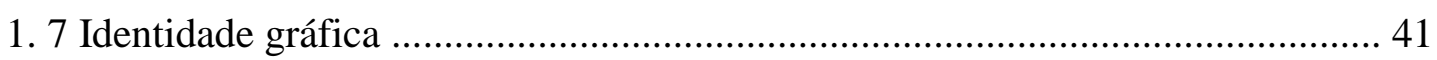

1.8 Avaliação QUALIS e credenciamento USP ....................................................... 45

1.9 A revista e o curso de Licenciatura em Educomunicação .................................... 48

2. Formulação do problema da pesquisa ................................................................ 50

3. Referências teóricas da pesquisa …………………………................................. 52

3.1 História, cotidiano e identidade …………………………………………...... 52

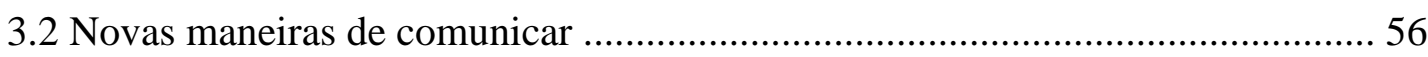

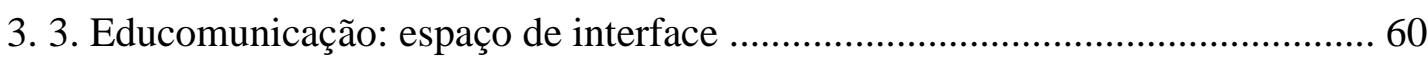

Educomunicação e linguagem: revendo os processos educacionais ................... 62

Educomunicação e "Ecossistema Comunicativo" ............................................... 65

Educom como política pública ........................................................................ 67

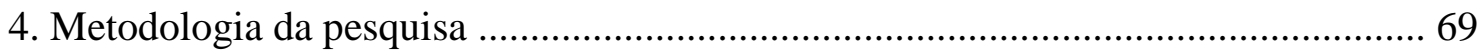

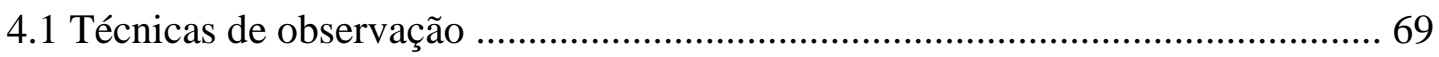

A análise de enquadramento ………………………………............................ 70

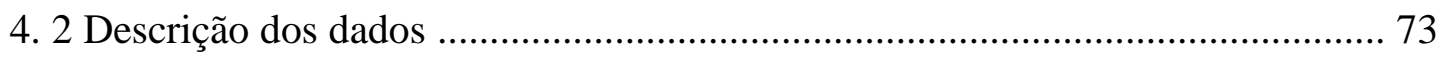

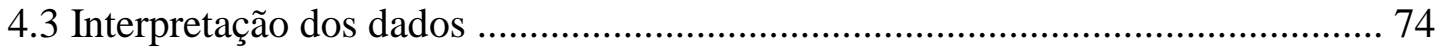

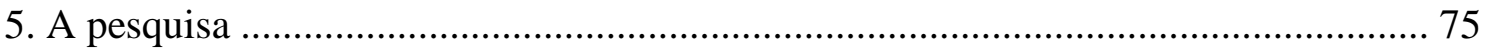

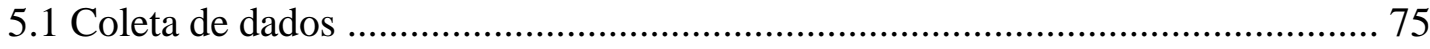

5.1.1 Observação Direta .................................................................................. 75

5.1.2 Pesquisa Bibliográfica ……………………………………………… 75

5.1.3 Entrevistas em profundidade .................................................................... 75 


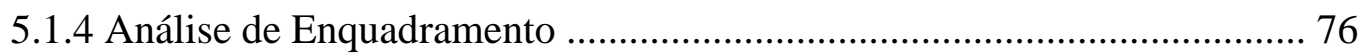

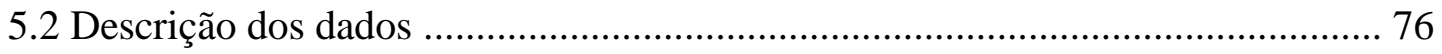

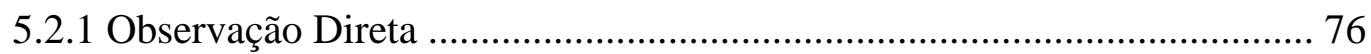

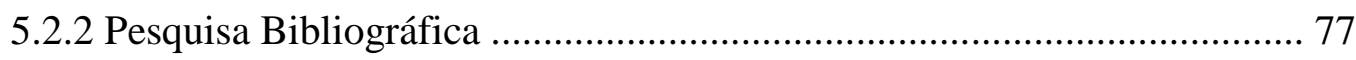

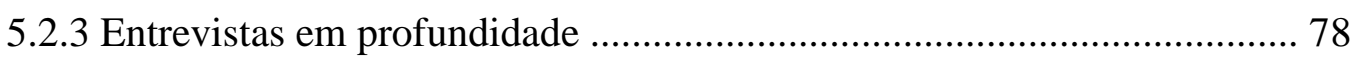

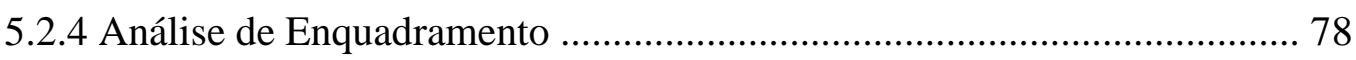

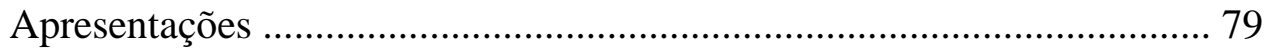

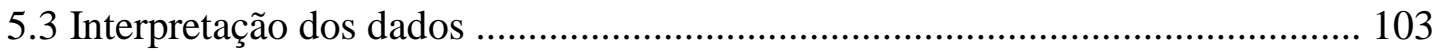

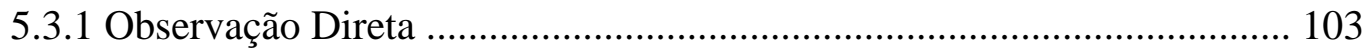

5.3.2 Pesquisa Bibliográfica ....................................................................... 104

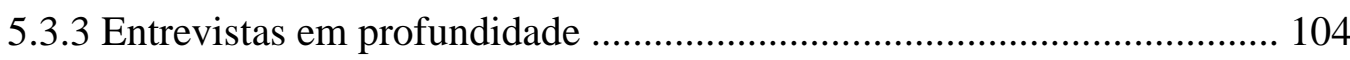

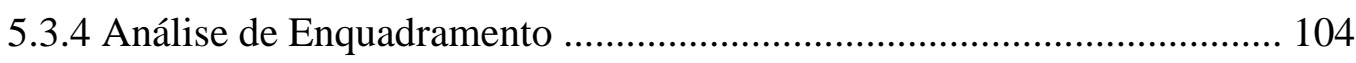

Artigos Nacionais …....................................................................... 107

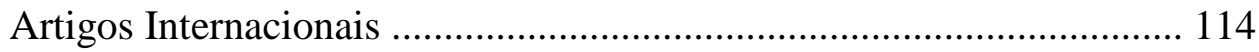

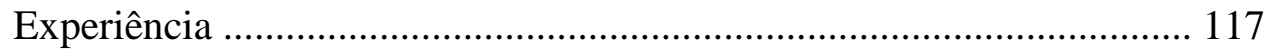

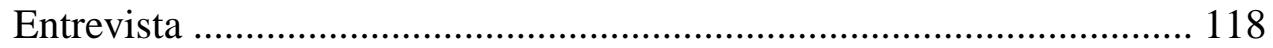

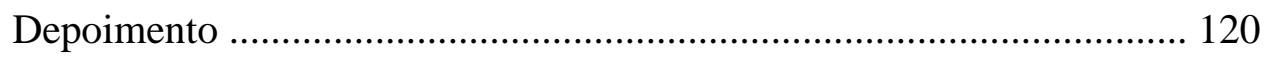

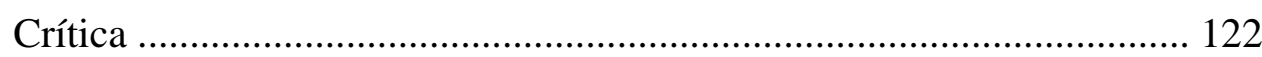

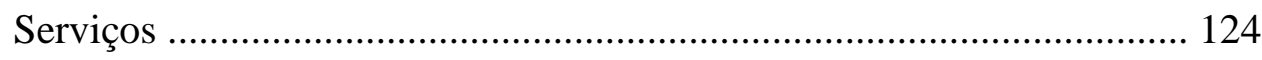

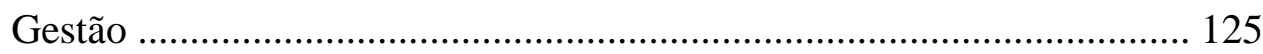

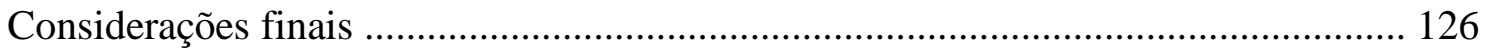

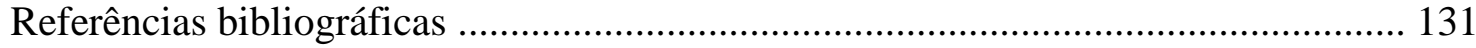

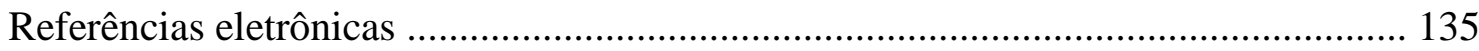

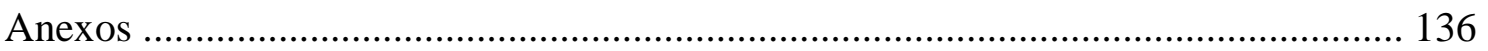

Anexo 1 - Ficha técnica de Comunicação \& Educação ...................................... 152

Anexo 2-Conteúdo integral das entrevistas em profundidade ............................ 139

Anexo 3 - Reproduções de capas de Comunicação \& Educação .......................... 153

Anexo 4 - Ocorrência de temas por seção (autores e palavras-chave) ................... 159 
Desde o início de minha atuação profissional como jornalista, estive envolvida com o trabalho junto a publicações e instituições ligadas à educação. A afinidade com a prática relacionada a esta área do saber surgiu já durante a faculdade de jornalismo e se fortaleceu por meio do trabalho desenvolvido em instituições que, dentro de suas especificidades, promoviam o desenvolvimento de atividades tanto nos campos comunicacional como educacional. Entre as experiências relacionadas, estiveram o trabalho como repórter e redatora, de 1999 a 2001, na revista eletrônica IntegrAção, publicada pela Fundação Getúlio Vargas e especializada em gestão do Terceiro Setor; a atuação, entre 2004 e 2007, na revista Almanaque Brasil, com foco em cultura brasileira e educação; o trabalho como analista de comunicação, entre 2007 e 2008, na Fundação Abrinq pelos Direitos da Criança, voltada aos direitos da infância e da adolescência; e, desde 2009 até o momento, a atuação na Associação Amigos do Guri, organização gestora do Projeto Guri, que oferece ensino musical gratuito a cerca de 50 mil jovens e adolescentes em mais de 350 Polos distribuídos pelo Estado de São Paulo.

O contato com diferentes realidades e com públicos heterogêneos, seja para escrever matérias especializadas, planejar e executar ações de comunicação ou elaborar e editar conteúdo destinado a atividades educacionais, reforçou o desejo por conhecer mais sobre a interface entre comunicação e educação, assim como a convicção sobre as importantes possibilidades de atuação conjunta dessas duas áreas. Após alguns anos de trabalho no mercado, decidi aliar a experiência aprendida na prática ao conhecimento acadêmico mais aprofundado. Esse caminho começou a ser trilhado, entre os anos de 2004 e 2005, através do curso de pós-graduação lato sensu em Gestão de Processos Comunicacionais do Departamento de Comunicações e Artes da ECA/USP.

À época, o curso tinha por objetivo:

Formar profissionais capazes de atuar no campo da comunicação, de maneira integrada: sem a fragmentação das diversas opções profissionais (publicidade, relações públicas, jornalismo etc.), das quais 
não prescinde e com as quais interage, esse profissional - gestor da comunicação - será capaz de articular as diversas mídias e os diversos suportes da comunicação, da interpessoal àquela que a sofisticação da tecnologia permite, mobilizando todas essas facetas em função dos objetivos de uma empresa, de uma instituição ou de uma escola. ${ }^{1}$

Após concluído o curso de pós-graduação, passei a colaborar na produção de conteúdo para a revista Comunicação \& Educação, ligada ao referido curso publicação que é objeto desta pesquisa de Mestrado. Como colaboradora da revista, tive a oportunidade de participar da realização e do planejamento de suas edições desde o ano de 2006, através das seções Entrevista, Depoimento e Endereços úteis na internetalém de contribuir com a edição e revisão de artigos acadêmicos. A elaboração das matérias, assim como o acompanhamento do processo de produção da publicação, foram determinantes para ampliar minha visão acerca da relação entre comunicação e educação, assim como para me aproximar de reflexões e exemplos práticos de trabalhos que utilizassem seus conceitos para integrar as mais diversas áreas do saber.

Como resultado desta trajetória, surgiu o projeto que originou esta pesquisa, que tem, por um de seus objetivos, analisar a identidade e evolução editorial da revista dentro do momento histórico em que foi criada - assim como sua contribuição para a consolidação da interface entre a educação e a comunicação, como uma nova área de pesquisa e atuação. Como será aprofundado a seguir, a revista Comunicação \& Educação surgiu em um momento particular da história do país, juntando-se às reflexões acerca do papel que a educação formal e informal, os meios de comunicação e os movimentos de mobilização social exercem, juntos, na formação de um novo perfil de cidadão. O presente trabalho, desta forma, pretende mostrar como a revista tem se relacionado, ao longo de quase duas décadas, com esse novo momento das práticas comunicacionais e educacionais que se afirma não só no Brasil, mas em toda a América Latina e em outras partes do mundo.

Ao contrário de esgotar o assunto, devido à natureza do trabalho e à abrangência e importância do tema, a pesquisa realizada aqui pretende, a partir da análise do

\footnotetext{
${ }^{1}$ Conforme definições do curso no endereço eletrônico http://www.eca.usp.br/departam/cca/cca/pos/lato/pos gestao.htm. Acesso em 03.06.2011.
} 
universo interno da revista, dar sua contribuição para a observação do processo histórico que se desenrolou fora dela ao longo dos últimos dezoito anos. Os temas, linhas teóricas e abordagens percorridos oferecem importante oportunidade de reflexão acerca dos panoramas político e social mundiais, com foco, especialmente, no Brasil e nos países da América Latina. Dessa forma, reforça-se também o importante papel de registro e participação na história, que a comunicação preza, aliado à formação de pessoas mais preparadas para serem agentes dessa mesma história - um dos papéis fundamentais da educação. 


\subsection{Histórico}

A revista Comunicação \& Educação foi criada em 1994 como publicação específica do curso de pós-graduação lato sensu Gestão de Processos Comunicacionais - que deu origem ao atual curso de especialização Educomunicação: Comunicação, Mídias e Educação - organizado também em 1994 pelo Departamento de Comunicações e Artes (CCA) da ECA/USP. A criação do curso de pós-graduação refletia o momento pelo qual passavam a área de pesquisa em comunicação e a própria Escola de Comunicações e Artes. Diante do movimento geral que se delineava dentro do ensino acadêmico, de priorização do conhecimento técnico, os professores do Departamento de Comunicações e Artes defendiam a necessidade de se reforçar as bases teóricas da formação dos profissionais - evidenciando o conteúdo reflexivo dos cursos e, ao mesmo tempo, aumentando ao máximo o intercâmbio de conhecimentos entre a universidade e a sociedade civil, assim como entre os pesquisadores e docentes da própria USP. A professora Maria Aparecida Baccega, à época chefe do Departamento, explica:

Sempre consideramos que os conteúdos que dávamos no CCA - nós éramos professores vindos das áreas de Letras, de Sociologia, de Filosofia, de Matemática etc. - eram indispensáveis ao profissional. Tínhamos uma relação com o mercado, mas não de submissão. Relação de intercâmbio. (...) Começamos a fazer planos - resolvemos montar um curso, que passou a ter o nome de Gestão de Processos Comunicacionais. (...) O Departamento passou a ter, então, dois cursos de pós-graduação: a pós-graduação stricto sensu e a pós-graduação lato sensu. $^{2}$

\footnotetext{
${ }^{2}$ FIGARO, Roseli. Dez anos de Comunicação \& Educação. Comunicação \& Educação, ano 10, n. 3. São Paulo, ECA/USP, 2005. p. 331.
} 
Embora tenha passado por mudanças e adequações em seu currículo, ao longo de quinze anos de atividades, o curso Gestão da Comunicação manteve seus objetivos principais:

a) Estudar as relações entre Comunicação, Cultura e Educação, sistematizando os conhecimentos sobre o tema fornecidos pelas áreas das Teorias da Comunicação, Teorias da Arte e Filosofias da Educação.

b) Identificar, na prática social, os espaços profissionais abertos a partir dos processos comunicacionais oriundos da inter-relação Comunicação Social/Cultura/Educação.

c) Discutir o uso dos recursos da Comunicação/Cultura no processo de ensino aprendizagem.

d) Contribuir para formar gestores de comunicação na educação formal e nãoformal. $^{3}$

Como forma de dar voz às discussões suscitadas dentro do universo abordado pelo curso, foi criada a revista Comunicação \& Educação. Adilson Citelli, um dos editores da revista desde o ano de 2004, detalha:

O curso de gestão cumpria, de um lado, uma finalidade de agregação dos professores em torno de um projeto que tinha tudo a ver com o Departamento - já que o curso de Gestão tinha essa preocupação formativa, claro que numa modalidade mais condensada - e que surgiu com características muito distintas mesmo dos cursos de lato sensu ou especialização que existiam, que eram cursos mais tópicos, com informação mais dirigida - enquanto nós estávamos preocupados com a formação mais global do aluno, ou seja, em dar a ele uma fundamentação maior na área da comunicação, da cultura, das artes. A partir disso, se articula imediatamente o curso com a revista, que passa a ser o lugar em que se pode ampliar esse debate que não era possível ao Departamento estritamente falando, por uma questão até mesmo institucional. O curso surgia com uma marca do Departamento, caracterizando o Departamento. E a revista podia ser, agora, porta-voz

\footnotetext{
${ }^{3}$ Disponível em http://www.eca.usp.br/gestcom/pdf/programadocurso.pdf. Acesso em 30.04.2012.
} 
desse debate, indicando o interesse do Departamento em discutir temas como o da Gestão da Comunicação, da Comunicação e Educação e assim por diante. Tanto é que a revista nasce dentro do Curso de Gestão. $^{4}$

A preocupação em intensificar este debate, por meio de uma revista especializada, também foi suscitada pelas intensas mudanças que se faziam notar no próprio modelo comunicacional vivenciado à época pela sociedade:

Em 1994, por exemplo, ainda não existia internet na escola. Fazíamos pesquisa com professores naqueles anos em um mundo muito diferente. Quase ninguém tinha computador. A telefonia móvel praticamente inexistia. Porém, verificava-se que essa "terceira onda" informáticomidiática que estava surgindo, para usar a expressão de Pierre Levy, iria desembocar na escola necessariamente. E isso não poderia ocorrer, enfim, numa perspectiva tecnicista, simplesmente trocando o projetor de slides pelo datashow. Queríamos mobilizar o debate junto aos educadores e comunicadores para darmos conta dessa nova singularidade que as mídias estavam trazendo, e que as novas tecnologias estavam propondo - mas queríamos dialogar com quem estava na ponta do processo, não apenas com quem estava na universidade. Dessa forma, seguimos um projeto político-editorial que contempla o diálogo com um universo profissional, social e cultural maior do que aquele estrito ao mundo da universidade, da pósgraduação, etc. $^{5}$

Citelli destaca também a conjuntura política e social vivida pelo país, importante na percepção da necessidade da nova publicação:

Vivíamos um momento forte de redemocratização e achávamos que uma publicação poderia ajudar, também, na reconstituição desse país que vinha surgindo a partir da Constituição de 1988 , ou seja, a partir

\footnotetext{
${ }^{4}$ Entrevista concedida pelo professor Adilson Citelli em 12.01.2012, em São Paulo/SP.

${ }^{5}$ Idem.
} 
daquilo que, teoricamente ou tecnicamente, era dado como o fim da Ditadura Militar. Naquele momento, muitos dos professores queriam ter uma inserção pública maior, um debate mais próximo com a sociedade dar a conhecer o que se fazia aqui, ampliar a participação e a discussão. Esses pontos justificam, contextualmente, a ideia da criação da revista. ${ }^{6}$

A proposta de realizar uma publicação de linha editorial aberta, reunindo em seu conselho editorial professores de diversos departamentos da USP, foi também uma tentativa de reforçar o diálogo mútuo entre as diferentes linhas de pesquisa da Escola de Comunicações e Artes - que vinha, naquele momento, vivenciando um movimento de centralização das atividades em departamentos autônomos e independentes - além de evidenciar a necessidade e viabilidade da aproximação entre a academia e o campo onde os conhecimentos poderiam ser aplicados, como assinala Cristina Costa, também editora da revista desde 2004:

É importante lembrar que, no Departamento, os professores envolvidos com a revista estiveram envolvidos também em projetos de aplicação de suas ideias e propostas pedagógicas - como o Educom.radio e o Educom.TV. O professor Ismar, a professora Roseli, o professor Adilson, a professora Baccega, eu, trabalhamos nesses projetos. Então, inevitavelmente, também a história do Departamento acabou influenciando neste enfoque. Houve uma resposta da sociedade civil no sentido de saber para que servia aquilo que dizíamos que sabíamos. ${ }^{7}$

Essas características gerais justificam a criação da revista nos moldes em que foi concebida. Desde esse momento, um dos grandes desafios propostos pela publicação foi o de unir a reflexão, expressa pela presença de pesquisas e artigos acadêmicos, com o conteúdo facilmente aplicável ao cotidiano de educadores e comunicadores, por meio de seções que aliassem aquele formato aos moldes jornalísticos de apuração e redação. Sendo assim, da mesma forma que estabelece canais para a publicação científica das pesquisas no campo da comunicação e educação, é também um apoio às atividades didáticas dos educadores, estimulando-os a utilizar a comunicação e a mídia em

\footnotetext{
${ }^{6}$ Entrevista concedida pelo professor Adilson Citelli em 12.01.2012, em São Paulo/SP.

${ }^{7}$ Entrevista concedida pela professora Maria Cristina Castilho Costa em 10.01.2012, em São Paulo/SP.
} 
atividades docentes - refletindo, discutindo e ressignificando os conteúdos midiáticos. Sua proposta editorial é dialogar com o público leitor sobre o espaço, já constituído, onde Educação e Comunicação se encontram. ${ }^{8}$ Nas palavras de Ismar de Oliveira Soares:

A convicção de seus promotores residia na perspectiva de que uma abertura da área da comunicação para um diálogo fecundo com o setor educativo viria facilitar, ao longo de um período de tempo, a renovação de referenciais e procedimentais do modus operandi dos dois campos envolvidos no processo: o da comunicação e o da educação. Eminentemente acadêmica, pois nascia no espaço de uma universidade, a revista, escrita majoritariamente por pesquisadores, definiu como política editorial inegociável o diálogo com o professor do ensino básico. Isso implicava o estilo a ser adotado e a presença do professor como autor, no relato de suas experiências. A publicação assumia seu perfil de intelectual orgânico coletivo. ${ }^{9}$

Além de espelhar a produção relacionada a esses dois temas dentro e fora da ECA, afirmando a intenção de unidade e diálogo conjuntos na própria Universidade, a revista também teve papel determinante na discussão geral sobre esta área de interface dentro do mercado de trabalho, abrindo espaço para o estabelecimento de um curso de Licenciatura em Educomunicação - conceito a ser discutido mais adiante por este trabalho -, administrado pelo Departamento de Comunicações e Artes e cuja primeira turma, composta por 30 alunos das mais diversas formações, teve início em fevereiro de 2011. De acordo com Ismar Soares, o curso “destina-se a preparar profissionais para atender a demandas provenientes tanto do campo da educação formal (magistério) quanto do campo das práticas comunicativas empreendidas pelos diversos setores da sociedade (mídia, organizações do terceiro setor, empresas e escolas)". ${ }^{10}$

\footnotetext{
${ }^{8}$ BACCEGA, Maria Aparecida. Do mundo editado à construção do mundo. Comunicação \& Educação, ano 1, n.1. São Paulo, ECA/USP, 1994. p. 7.

9 SOARES, Ismar de Oliveira. A contribuição da revista Comunicação \& Educação para a criação da Licenciatura em Educomunicação. Comunicação \& Educação, ano 14, n. 3. São Paulo, ECA/USP, 2009. p. 8.

${ }^{10}$ Idem. p. 9.
} 
Para a professora e matemática Ruth Ribas Itacarambi, responsável pela seção Atividades em Sala de Aula da revista Comunicação \& Educação - portanto, especializada em estabelecer a relação entre o conteúdo teórico e as possibilidades de atividades práticas oferecidas pela revista - o novo curso é uma forma de estimular a discussão centrada não na educação ou na comunicação, mas percebendo a intersecção dos dois campos como uma perspectiva nova de atuação.

Na área de matemática, por exemplo, temos diversas vertentes de ensino e pesquisa, mas não temos matemática aplicada à educação. E quando os alunos vão lidar com isso depois, em sua vida profissional, se sentem despreparados, pois falta fundamentação e não sabem onde podem buscá-la. Por isso é fundamental a troca de conhecimentos entre pessoas e organizações. O próprio curso de Gestão já abriu muito as perspectivas dos dois campos para isso. ${ }^{11}$

O fortalecimento do diálogo entre as duas áreas motivou também a reformulação, no ano de 2011, do próprio curso Gestão da Comunicação, que a partir do ano seguinte passou a ser direcionado especificamente à área de Educomunicação. A mudança, de acordo com a direção do Departamento de Comunicações e Artes, foi proveniente de cinco grandes movimentos pedagógicos realizados pela ECA em torno do tema:

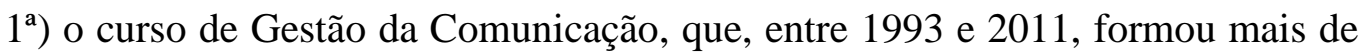
600 especialistas;

$2^{\mathrm{a}}$ ) a criação e manutenção da Revista Comunicação \& Educação, um dos três periódicos mais utilizados pelos pesquisadores do campo da comunicação em teses acadêmicas;

$\left.3^{a}\right)$ os cursos de aperfeiçoamento, extensão e especialização em Educomunicação, implementados pelo Núcleo de Comunicação e Educação (NCE), atendendo, desde o ano 2000, a mais de 30 mil pessoas em todo o país;

\footnotetext{
${ }^{11}$ Entrevista concedida pela professora Ruth Ribas Itacarambi em 26.01.2012, em São Paulo/SP.
} 
$4^{a}$ ) os projetos de consultoria a governos (em nível municipal, estadual e federal) para a implementação do conceito da Educomunicação como política pública, incluindo, entre estas experiências, a assessoria ao Ministério do Meio Ambiente em seu programa de Educomunicação Socioambiental (a prática educomunicativa nas 350 áreas de preservação ambiental do país) e ao Ministério da Educação (a implementação de cursos a distância para mais de dez mil professores no Estado de São Paulo) e, finalmente,

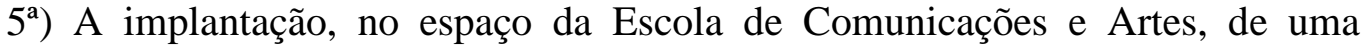
Licenciatura em Educomunicação. ${ }^{12}$

O posicionamento de Comunicação \& Educação acompanhou todas as mudanças promovidas pelo Departamento. Em 2011, durante a reformulação do Curso Gestão da Comunicação para dar origem ao novo Curso de Especialização Lato Sensu Educomunicação: comunicação, mídias e educação, a revista passou, por fim, à responsabilidade do próprio Departamento de Comunicações e Artes, como forma de garantir sua sustentabilidade durante o período de transição e formação de novas turmas do Curso. O ajuste foi propício também do ponto de vista conceitual, já que a produção da publicação, a essa altura, representava não apenas o Curso de Especialização já citado, mas o Departamento de Comunicações e Artes de maneira geral.

Sua periodicidade, a partir de então, passou de quadrimestral para semestral mais afinada, portanto, ao planejamento das atividades dos profissionais de educação, que normalmente organizam semestralmente os cronogramas e temas a serem trabalhados junto aos alunos. As mudanças, porém, não influíram no propósito editorial inicial de refletir a teoria e sistematizar experiências, como explica Baccega:

A revista se chama "Comunicação \& Educação" porque esse é um campo que tem que formular teorias a respeito de produção de sentido. A produção de sentido tem um pé em cada um desses dois lugares. Compete a nós fazer com que as questões de comunicação e educação entrem na escola, ao invés de serem discutidas no recreio ou em outros

\footnotetext{
12 Disponível em http://www.cca.eca.usp.br/especializacao/1222. Acesso em 30.04.2012.
} 
lugares - porque, de uma forma ou de outra, elas são sempre discutidas. ${ }^{13}$

\section{2 Comissão editorial}

Os professores que conceberam a linha editorial da revista foram os mesmos que idealizaram o curso Gestão da Comunicação - e, portanto, tiveram como propósito trabalhar para que a publicação pudesse se aproximar da trajetória e dos temas tratados no curso. Segue um breve perfil de cada um deles. ${ }^{14}$

\section{Adilson Odair Citelli}

Atual editor da revista Comunicação \& Educação, ao lado da professora Maria Cristina Castilho Costa. Possui graduação em Letras pela Universidade de São Paulo (1973), onde também realizou mestrado (1982) e doutorado (1990), ambos na área de Literatura Brasileira. Em 1995 fez livre docência pela ECA/USP, com tese sobre a inter-relação entre comunicação e educação. Em 2007 assumiu o cargo de Professor Titular junto ao Departamento de Comunicações e Artes da ECA/USP, onde já vinha lecionando dentro dos programas de graduação e pós-graduação. Ministra cursos e orienta dissertações e teses nas áreas de Comunicação e Linguagem, com ênfase nas sub-áreas de comunicacão/educacão, Educomunicação e comunicação/linguagem. É ainda pesquisador do Conselho Nacional de Desenvolvimento Científico e Tecnológico (CNPq). Entre os inúmeros artigos e livros de sua autoria já publicados, destacam-se os títulos Linguagem e persuasão (Ática); Comunicação e educação: a linguagem em movimento (SENAC); Palavras, meios de comunicação e educação (Cortez) e Educomunicação. Construindo uma nova área de conhecimento (Org.com Cristina Costa, Paulinas).

\section{Ismar de Oliveira Soares}

Atual Chefe do Departamento de Comunicações de Artes da ECA, integrante da Comissão de Publicação e do Conselho Editorial da revista. Bacharel em Geografia, Licenciado em História pela Faculdade Salesiana de Filosofia, Ciências e Letras de

\footnotetext{
${ }^{13}$ Entrevista concedida pela professora Maria Aparecida Baccega em 27.04.2012, em São Paulo/SP.

14 Os perfis foram elaborados com base em informações da plataforma Lattes (http://lattes.cnpq.br/) e de pesquisa complementar e bibliográfica específica.
} 
Lorena, SP (1965) e jornalista formado pela Faculdade Cásper Líbero (1970). Mestre (1980) e Doutor em Ciências da Comunicação (1986) pela Universidade de São Paulo, com pós-doutorado, em 2000, pela Marquette University Milwaukee, WI, USA. Coordena, desde 1996, o NCE - Núcleo de Comunicação e Educação da ECA/USP. Foi pesquisador da Fundação de Amparo à Pesquisa do Estado de São Paulo (FAPESP) entre 1997 e 1999, tendo concluído, por meio deste trabalho, que a Educomunicação pode ser considerado um campo emergente. Promoveu, em 2002, o Projeto Educom.TV (curso online para dois mil professores do Estado de São Paulo, sobre o emprego da linguagem audiovisual na escola sob a perspectiva da Educomunicação). Promoveu, entre 2001 e 2004, o Projeto Educom.rádio (formação de 11 mil professores e alunos da rede municipal de ensino de São Paulo para o uso educomunicativo da linguagem radiofônica no espaço escolar). Presidiu, entre 2001 e 2009, a UCIP - Union Catholique Internationale de la Presse, com sede em Genebra, Suíça. Durante o mesmo período, foi membro do Pontifício Conselho para as Comunicações do Vaticano. Atualmente é avalista de projetos de pesquisa da FAPESP na área da Educomunicação, além de professor titular da Universidade de São Paulo. É ainda membro de Comitê Gestor da Lei Educom da Prefeitura do Município de São Paulo e Supervisor do Projeto Mídias na Educação, do Ministério da Educação no Estado de São Paulo. Coordenou também a implementação da Licenciatura em Educomunicação junto à Escola de Comunicações e Artes da USP.

\section{Maria Aparecida Baccega}

Fundadora e primeira editora, entre 1994 e 2003, da revista Comunicação \& Educação; atual membro de seu Conselho Editorial e de sua Comissão de Publicação. Livre Docente em Comunicação pela Escola de Comunicações e Artes da USP, atualmente aposentada. Docente, pesquisadora e orientadora do Programa de Mestrado Comunicação e práticas de consumo da Escola Superior de Propaganda e Marketing SP - do qual foi coordenadora adjunta de 2003 a 2007. Professora e pesquisadora da Escola de Comunicações e Artes, tendo lecionado nos cursos de graduação e pós-graduação stricto e lato sensu. Entre outros cargos, foi Chefe do Departamento de Comunicações e Artes da ECA entre 1992 a 1996. Entre os anos de 1993 e 2003, coordenou a equipe fundadora do Curso de Gestão da Comunicação, tendo sido também Coordenadora do curso, além de docente e orientadora. Pesquisadora do Centro de Pesquisa de Telenovela e do Centro de Pesquisa Comunicação e Trabalho, ambos da USP; do 
Núcleo de Pesquisa Comunicação e Práticas de Consumo, da ESPM-SP; e do OBITEL (Observatório Iberoamericano de Ficção Televisiva), que congrega países da América Latina e Europa Ibérica, além da Itália. É ainda membro do Conselho Editorial de diversas revistas acadêmicas, entre as quais a revista Comunicação, Mídia e Consumo, editada pelo programa de Mestrado da ESPM. Oferece vasta contribuição aos campos da Comunicação e Educação por meio de artigos e obras diversas, entre as quais Palavra e discurso (Ática); Comunicação e linguagem (Moderna); Televisão e escola: uma mediação possível? (Senac); Gestão de processos comunicacionais (org.) (Atlas) e Comunicação e culturas do consumo (org.) (Atlas).

\section{Maria Lourdes Motter (in memoriam)}

Graduada em Letras, Língua Portuguesa e Literatura e bacharel em Lingüística pela Universidade de São Paulo. Pela mesma instituição, obteve o título de mestre em Lingüística e doutora em Ciências da Comunicação. Foi Professora Livre-Docente do Departamento de Comunicações e Artes da Escola de Comunicação e Artes da USP, ministrando cursos de graduação e pós-graduação (lato e stricto sensu) de 1989 a 2007. Atuou no Conselho de Editores e na Comissão de Publicação da revista Comunicação \& Educação, sendo responsável, de 1994 a 2007, pela seção Bibliografia sobre Telenovela Brasileira. Atuou como parecerista da Fundação de Amparo à Pesquisa do Estado de São Paulo (FAPESP) e do Conselho Nacional de Desenvolvimento Científico e Tecnológico (CNPq), além de avaliadora de projetos do Programa de Apoio à Instalação de Doutores no Estado da Bahia. Foi vice-coordenadora e pesquisadora do Núcleo de Pesquisa de Telenovela da ECA/USP, além de coordenadora do Núcleo de Pesquisa Ficção Seriada da Sociedade Brasileira de Estudos Interdisciplinares da Comunicação (Intercom). É autora das obras Ficção e História (Arte e Ciência) e Ficção e Realidade (Alexa Cultural), além de inúmeros artigos em periódicos especializados e participações em publicações diversas e anais de eventos.

\section{Solange Martins Couceiro de Lima}

Possui graduação em História (1968), mestrado em Antropologia (1971) e doutorado em Ciências da Comunicação, todos pela Universidade de São Paulo (1984). Professora Assistente da USP, integra o Conselho Editorial e a Comissão de Publicação da revista Comunicação \& Educação. Coordenou projetos e escreveu diversos artigos, contribuições e textos na área de antropologia, com ênfase em antropologia das 
populações afro-brasileiras. Atua, principalmente, em atividades relacionadas aos seguintes temas: mulher, família, mulher negra, evolucionismo e racismo. É autora das obras O negro na televisão de São Paulo (FFLCH - USP) e Bibliografia sobre o negro brasileiro (ECA/USP - CODAC/USP).

\section{Virgílio B. Noya Pinto (in memoriam)}

Historiador, comunicador e Professor Doutor Titular do Departamento de Comunicações e Artes da ECA/USP durante a década de 1990. Integrante do Conselho Editorial e da Comissão de Publicação da revista Comunicação \& Educação. Autor de inúmeras contribuições para o campo da comunicação e da história, como Comunicação e Cultura Brasileira (Ática); O Ouro Brasileiro e o Comércio Anglo-Português (Nacional) e Século XX: uma análise precoce (ECA/USP).

A esta equipe, mais tarde, se somariam outros docentes que teriam participação ativa na trajetória da revista. São eles:

\section{Maria Cristina Castilho Costa}

A partir de 2003, assume a editoria da revista Comunicação \& Educação, ao lado do professor Adilson Citelli. Possui bacharelado e licenciatura em Ciências Sociais pela Pontifícia Universidade Católica de São Paulo (1973) e mestrado (1985) e doutorado (1990) em Ciências Sociais (Antropologia Social) pela Universidade de São Paulo. É livre docente em Ciências da Comunicação pela Escola de Comunicações e Artes da USP. Preside a Comissão de Pesquisa da ECA/USP, além de coordenar o Curso de Especialização Lato Sensu Educomunicação: comunicação, mídias e educação. É também coordenadora do NPCC - Núcleo de Pesquisa em Comunicação e Censura da USP e do Projeto Temático Comunicação e Censura - Análise teórica e documental de processos censórios a partir do Arquivo Miroel Silveira da ECA/USP, com apoio da FAPESP. Tem experiência na área de sociologia com ênfase em artes e comunicação, atuando principalmente junto aos seguintes temas: comunicação, arte, educação, sociologia e comunicação digital. É autora de inúmeros artigos e diversas obras relacionadas a esses campos, como Teatro e Censura - Vargas e Salazar (EDUSP/FAPESP); Censura em cena (EDUSP) e Sociologia: Introdução à Ciência da Sociedade (Moderna). 


\section{Maria Immacolata Vassallo de Lopes}

Possui graduação em Ciências Sociais, mestrado e doutorado em Ciências da Comunicação pela Universidade de São Paulo e pós-doutorado pela Universidade de Florença, Itália. É professora titular da Escola de Comunicações e Artes da USP. Sua experiência concentra-se na área de comunicação, com ênfase em epistemologia da comunicação, teoria da comunicação e metodologia da pesquisa em comunicação. Atua principalmente nos seguintes temas: campo da comunicação, recepção da comunicação, ficção televisiva e metodologia da comunicação. É coordenadora do Programa de PósGraduação em Ciências da Comunicação da USP, do Centro de Estudos de Telenovela da USP e do Centro de Estudos do Campo da Comunicação da USP. Criadora e coordenadora da rede de pesquisa internacional OBITEL - Observatório IberoAmericano da Ficção Televisiva e da rede de pesquisa OBITEL-Brasil. Foi representante da área de Comunicação no CNPq (2004-2007). É integrante do Conselho Curador da Sociedade Brasileira de Estudos Interdisciplinares da Comunicação (Intercom), como ex-presidente da entidade. Exerce atualmente a Presidência da IBERCOM - Associação Ibero-Americana de Comunicação (2012-2015). É também diretora de MATRIZes, Revista do Programa de Pós-Graduação em Ciências da Comunicação da USP, e membro do conselho editorial de diversos periódicos nacionais e internacionais - entre elas a revista Comunicação \& Educação. É pesquisadora do $\mathrm{CNPq}$ e autora de livros e artigos publicados nacional e internacionalmente em sua área.

\section{Roseli Aparecida Figaro Paulino}

Atuou como colaboradora regular e Editora Executiva da revista Comunicação \& Educação do número 2 ao número 26 e, atualmente, faz parte de seu Conselho Editorial. É graduada em Jornalismo pela Faculdade de Comunicação Social Cásper Líbero (1981), possui e mestrado (1993) e doutorado (1999) em Ciências da Comunicação pela Universidade de São Paulo e pós-doutorado pela Universidade de Provence, França (2007). É professora do Programa de Pós-Graduação em Ciências da Comunicação da Universidade de São Paulo, vice-chefe do Departamento de Comunicações e Artes e coordenadora do Grupo de Pesquisa Comunicação e Trabalho, além de pesquisadora do Núcleo de Pesquisa Comunicação e Censura - Análise teórica e documental de processos censórios a partir do Arquivo Miroel Silveira. Tem experiência na área de comunicação com ênfase em linguagem verbal e teorias da comunicação, atuando principalmente nos seguintes temas: comunicação e mundo do trabalho, gestão da 
comunicação, e comunicação/educação. Entre os títulos de sua autoria, estão Teatro, comunicação e sociabilidade: uma análise da censura ao teatro amador em São Paulo (Balão Editorial) e Relações de Comunicação no mundo do trabalho (Anna Blume).

\section{3 Equipe, produção e distribuição}

A viabilização da revista Comunicação \& Educação veio, inicialmente, através de uma prática pouco usual entre as publicações acadêmicas: a parceria com uma editora comercial, neste caso a Editora Moderna, que publicou e distribuiu a revista durante suas primeiras 15 edições.

A alternativa de procurar editoras que trouxessem suporte econômico e financeiro à revista foi bastante pioneira, ao menos dentro da ECA, com segurança. A revista tem uma tiragem relativamente baixa para os padrões industriais das editoras. Dessa forma, a relação foi estabelecida devido ao interesse dessas empresas em manter um vínculo com a Universidade de São Paulo. Foi uma troca civilizada entre a Universidade, que fornecia a massa crítica da revista, sustentabilidade e imagem positiva, e a Editora, que por seu turno podia ampliar seu catálogo e, sobretudo, se colocar à disposição de um público importante do ponto de vista da formação de opinião, que eram os professores e pesquisadores. Isso permitiu que a revista tivesse a presença que tem hoje, já que faz parte do QUALIS de várias outras áreas - desde letras até ciências da saúde, que aparentemente não teria nada a ver com comunicação e educação, porém está lá por essa ser uma revista que circula no universo da área de saúde. Isto revela que a publicação têm uma abrangência além das áreas mais estritas da comunicação e da educação. $^{15}$

Esta parceria foi fundamental para garantir a sustentabilidade da produção da publicação, que, como também explica Citelli, procurava estabelecer, editorialmente,

\footnotetext{
${ }^{15}$ Entrevista concedida pelo professor Adilson Citelli em 12.01.2012, em São Paulo/SP.
} 
um diálogo entre o ambiente acadêmico e os profissionais envolvidos nos campos da comunicação e da educação.

Queríamos uma revista para fazer uma interlocução social mais ampla, que pudesse ter até um poder ampliado de negociação política no momento histórico de então. Buscávamos um diálogo mais próximo com os professores das redes públicas ou privadas de nível fundamental e de nível médio. Não seria possível, com esse target e essa preocupação editorial, fazer uma revista estritamente acadêmica. (...) Ela deveria cumprir parcialmente uma função acadêmica, por meio da publicação de textos nacionais e internacionais ligados às áreas de pesquisa da Universidade, ao lado de textos que ampliassem o diálogo com os setores sociais formados por professores e educadores no sentido amplo do termo, permitindo a esse circuito social entender melhor a presença da comunicação no mundo que surgia naquele momento.

Uma vez estabelecida a parceria, foi criado, dentro da Editora, um departamento exclusivo para gerar assinaturas da revista - ação que se reverteu em um número aproximado de três mil assinantes, considerado acima da média entra as publicações de caráter acadêmico. ${ }^{16}$ Foi organizada, também, uma agenda de divulgação em escolas e eventos ligados às duas áreas, além da distribuição em livrarias - procedimento não comumente adotado pela empresa, que comercializava seus livros diretamente junto às escolas. A produção de conteúdo caberia, sempre, ao Departamento de Comunicações e Artes da ECA, especialmente na figura da prof. Maria Aparecida Baccega, que esteve à frente da Comissão Editorial da revista até o ano de 2003.

No início, não tínhamos secretária, editora, nada disso. O material passava por pareceristas e depois era editado e revisado por mim. Depois de algum tempo, passaram a integrar a equipe uma secretária e a professora Roseli Figaro, então minha orientanda, que nos ajudou

\footnotetext{
${ }^{16}$ PIRES, Suzana Simões Ribeiro. Comunicação \& Educação - novas propostas de gestão da comunicação. 2005. Dissertação (Pós-graduação em Gestão de Processos Comunicacionais) Departamento de Comunicações e Artes da Escola de Comunicações e Artes da Universidade de São Paulo. p. 65.
} 
muito. O processo de elaboração da revista sempre foi bastante sofrido, sem grande respaldo financeiro, mas sempre de muito êxito. ${ }^{17}$

A partir de então, foi reservada uma sala no prédio central da ECA para acolher o arquivo da revista e sua equipe de elaboração, formada por uma jornalista, uma assistente editorial e uma estagiária. A sustentabilidade da publicação, relacionada às despesas de tradução dos textos (quando necessário), ao pagamento de parte da equipe de produção e aos custos com materiais de escritório, durante a primeira parceria, foi garantida pela Editora Moderna e, nos contratos com as demais editoras, pelo próprio curso Gestão de Processos Comunicacionais. À Editora caberia, sempre, a diagramação final da publicação de acordo com o projeto gráfico escolhido pela ECA, assim como a distribuição dos exemplares e ações de divulgação.

Desde o início, ficou estabelecido que ninguém interferiria no processo editorial da revista. $O$ trabalho das editoras se limitava ao trabalho gráfico. O sucesso da revista se deve a várias coisas, mas sobretudo (...) ao fato de ela ter sido feita, inteira, sempre aqui. Isso é uma conquista muito difícil e nós obtivemos. ${ }^{18}$

Da edição de número 16 em diante, a publicação passou a ser distribuída pela Editora Segmento, em uma parceria que se estendeu até seu número 22, em janeiro de 2002. A revista passou, então, a ser editada pela Editora Salesiana, até seu número 27. Seguiu-se uma pausa de um ano e cinco meses na publicação das edições, retomadas em 2005 por meio da parceria com a Editora Paulinas, em vigor até os dias atuais.

Atualmente, a tiragem de mil exemplares da publicação é distribuída, principalmente, entre pesquisadores e professores de ensino fundamental, médio e universitário; alunos de graduação e pós-graduação no Brasil, América Latina, Europa e Estados Unidos; e profissionais que trabalham junto aos meios de comunicação e a atividades comunicacionais envolvendo a educação. O preço da assinatura anual da revista é de $\mathrm{R} \$ 55,00$ - cinquenta e cinco reais. Para fazer chegar a publicação a esse

${ }^{17}$ Entrevista concedida pela professora Maria Aparecida Baccega em 27.04.2012, em São Paulo/SP.

${ }^{18}$ FIGARO, Roseli. Dez anos de Comunicação \& Educação. ano 10, n. 3. São Paulo, ECA/USP, 2005. p. 338. 
público e aos alunos da Licenciatura em Educomunicação, o Departamento de Comunicações e Artes da ECA adquire quatrocentos volumes de cada edição, distribuídos também entre os autores e o Conselho Editorial da revista.

\section{4 Presença na internet}

Em 1999, quatro anos depois da criação da publicação, foi lançado também o site da revista (www.eca.usp.br/comueduc), com o objetivo de disponibilizar resumos dos artigos já publicados e informações sobre os autores participantes de cada edição, além de um banco de dados acessado via busca por palavras-chave.

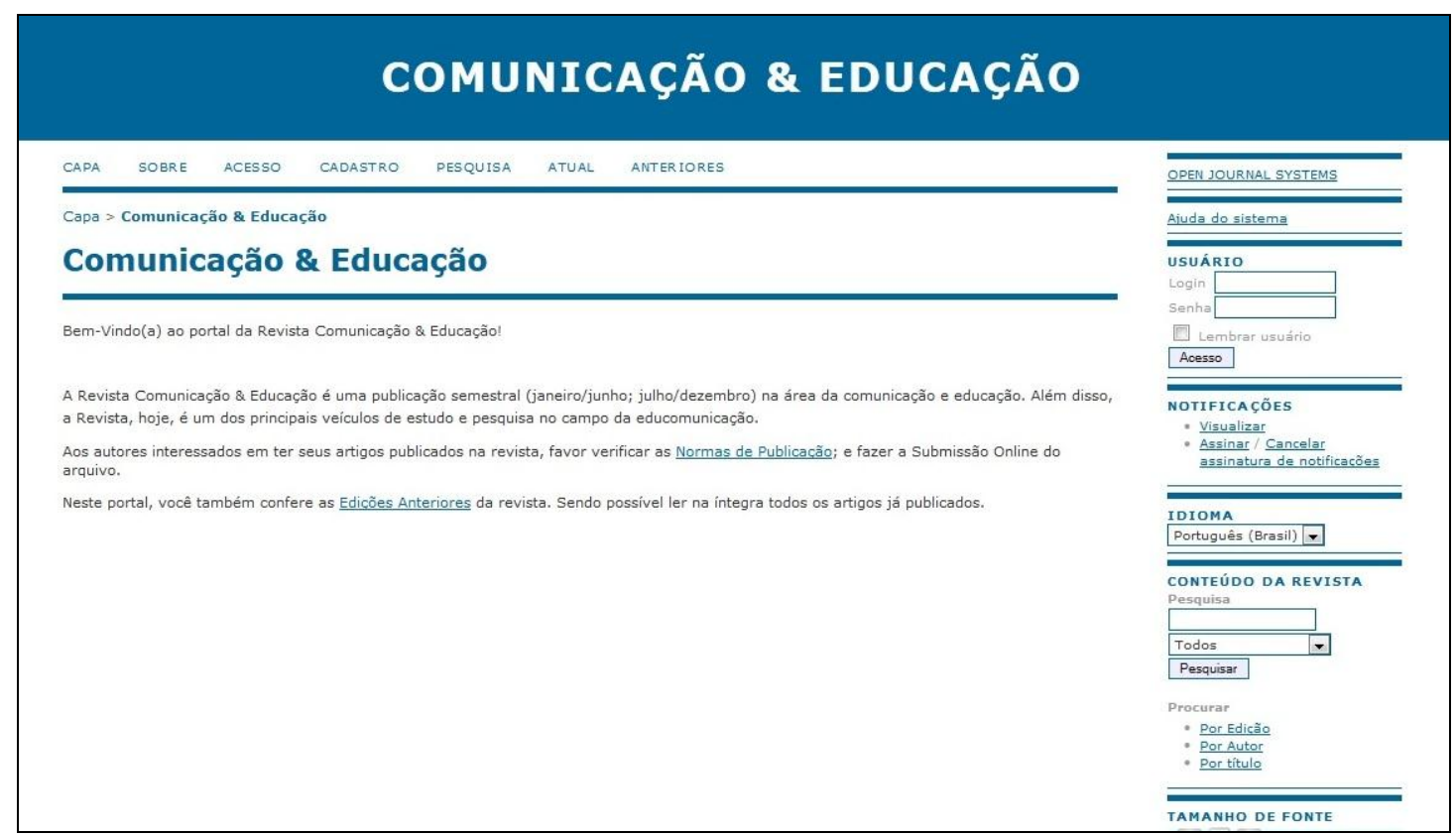

Ilustração 3. Homepage do site atual da revista Comunicação \& Educação (http://www.usp.br/comиeduc2/index.php/comиeduc). Acesso em 20.06.2012.

O site passou por duas reformas gráficas e sistemáticas nos anos de 2002 e 2005. Atualmente, está em andamento uma migração completa de conteúdo, devido à adoção de nova interface para a página virtual da revista (conforme imagem acima). Enquanto esta migração não é finalizada, os textos publicados entre 1994 e 1999 podem ser consultados no portal Univerciência (http://www.revistas.univerciencia.org/). Do Univerciência veio também, no ano de 2010, um importante indicativo da procura da revista pelos leitores no ambiente online: entre os 21 títulos de publicações da área de comunicação disponibilizados para consulta no portal, Comunicação \& Educação 
ocupava, à época da medição, o primeiro lugar em número de acessos - tendo registrado, de dezembro de 2008 a julho de 2009, 10.390 pageviews e 32.805 downloads de artigos.

A estatística é citada com destaque pela professora Maria Cristina Castilho Costa no editorial da edição de janeiro/abril de 2010. "Informação importante desse levantamento estatístico mostra que os textos mais antigos são ainda os mais consultados pelos visitantes. Isso significa que a revista Comunicação \& Educação, em importante portal de periódicos de comunicação, mantém expressiva liderança em visitas, acessos e downloads." 19

Da mesma forma, a inclusão da publicação no Portal USP de Periódicos Credenciados (http://www.revistasusp.sibi.usp.br/scielo.php) - lançado em 2008 com acesso ao texto completo das revistas produzidas pela Universidade e credenciadas pelo Programa de Apoio às Publicações Científicas Periódicas da Instituição - é sinal de reconhecimento do serviço prestado pela revista junto ao estudo acadêmico da interface entre comunicação e educação. A revista está presente, ainda, dentro do Portal de Periódicos da Coordenação de Aperfeiçoamento de Pessoal de Nível Superior (CAPES), como será detalhado mais adiante. Baccega evidencia o significado da presença no ambiente online - que, segundo ela, não significa prejuízo à importância da revista enquanto publicação impressa:

Disponibilizar o conteúdo da revista na internet não significa prejudicar as vendas da edição impressa, por exemplo. Pelo contrário, tenho a impressão de que estar na internet é uma publicidade para a revista. As pessoas ficam conhecendo e, se realmente se interessarem, começam a aguardar a publicação - até porque, devido ao perfil e tamanho dos textos, ainda são poucos os leitores que lêem um artigo inteiro com a atenção necessária na internet. Por isso, acho que sempre haverá lugar para a revista impressa e, nesse sentido, pode ser que o site funcione como uma peça publicitária. ${ }^{20}$

\footnotetext{
19 COSTA, Maria Cristina Castilho. Dificuldades e prazeres de uma publicação. Comunicação \& Educação, ano 15, n. 1, 2010. pp. 7-8.

${ }^{20}$ Entrevista concedida pela professora Maria Aparecida Baccega em 27.04.2012, em São Paulo/SP.
} 


\begin{tabular}{|c|c|c|c|c|c|c|c|c|c|}
\hline Revistas & 2008 & & & & 2009 & & & & Total \\
\hline & Dez. & Jan. & Fev. & Mar. & Abr. & Maio & Jun. & Jul. & \\
\hline Comunicação \& Educação & 1.161 & 829 & 1.112 & 875 & 760 & 1.556 & 1.475 & 2.622 & 10.390 \\
\hline Galáxia & 1.096 & 560 & 923 & 1.880 & 1.057 & 1.001 & 687 & 726 & 7.930 \\
\hline Libero & 1.001 & 235 & 266 & 534 & 688 & 1.584 & 1.331 & 798 & 6.437 \\
\hline Revista FAMECOS & 996 & 180 & 218 & 516 & 577 & 1.202 & 1.234 & 1.085 & 6.008 \\
\hline Anagrama & - & $\ldots$ & $\cdots$ & -- & $\cdots$ & 46 & 530 & 1.446 & 1.794 \\
\hline Comunicaçẩo \& Sociedade & 991 & 146 & 195 & 496 & 414 & 1.146 & 1.033 & 865 & 5.286 \\
\hline Comunicação, Midia e Consumo & 988 & 325 & 368 & 459 & 451 & 739 & 668 & 785 & 4.783 \\
\hline Rastros & 979 & 98 & 281 & 704 & 390 & 282 & 348 & 529 & 3.611 \\
\hline Media e Jornalismo & 945 & 16 & 90 & 601 & 416 & 591 & 441 & 443 & 3.543 \\
\hline Em Questão & 1.025 & 131 & 163 & 401 & 278 & 463 & 340 & 454 & 3.255 \\
\hline Organicom & 963 & 105 & 210 & 409 & 195 & 291 & 342 & 262 & 2.777 \\
\hline Fronteiras & 966 & 102 & 138 & 273 & 235 & 216 & 273 & 485 & 2.688 \\
\hline Estudos em Jornalismo e Mídia & 963 & 64 & 114 & 263 & 205 & 313 & 302 & 357 & 2.581 \\
\hline Verso e Reverso & $\cdots$ & 203 & 254 & 410 & 344 & 380 & 424 & 494 & 2.509 \\
\hline $\begin{array}{l}\text { Acervo On-Line de Midia } \\
\text { Regional }\end{array}$ & 985 & 85 & 115 & 290 & 187 & 224 & 170 & 277 & 2.333 \\
\hline Contracampo & 950 & 39 & 30 & 229 & 210 & 162 & 238 & 303 & 2.161 \\
\hline E-Com & 996 & 135 & 131 & 171 & 152 & 179 & 162 & 199 & 2.125 \\
\hline MATRIZES & 950 & 41 & 79 & 163 & 147 & 226 & 189 & 169 & 1.964 \\
\hline OBServatorio & 949 & 24 & 29 & 66 & 37 & 59 & 342 & 97 & 1.603 \\
\hline REBEJ & 923 & 12 & 52 & 64 & 101 & 96 & 47 & 72 & 1367 \\
\hline Rumores & -- & $\ldots$ & -- & -- & $\ldots$ & $\ldots$ & -- & 229 & 229 \\
\hline TOTAL & 17.827 & 3.330 & 4.768 & 8.850 & 7.374 & 12.156 & 11.840 & 12.792 & 78.937 \\
\hline
\end{tabular}

Ilustração 1. Distribuição mensal das visitas ao Portal Univerciencia.org - dez.2008/jul.2009²1

${ }^{21}$ FERREIRA, Sueli Mara Soares Pinto; TARGINO, Maria das Graças. Métricas alternativas de avaliação do impacto e do uso de revistas eletrônicas: estudo em ciências da comunicação. In: FERREIRA, Sueli Mara Soares Pinto; TARGINO, Maria das Graças (orgs.). Acessibilidade e visibilidade de revistas científicas eletrônicas. São Paulo: Senac/CENGAGE, 2010. p. 32. 


\begin{tabular}{|c|c|c|c|c|c|c|c|c|c|}
\hline \multirow{2}{*}{ Revistas } & \multicolumn{4}{|c|}{2008} & \multicolumn{4}{|c|}{2009} & \multirow{2}{*}{ Total } \\
\hline & Dez. & Jan. & Fev. & Mar. & Abr. & Maio & Jun. & Jut. & \\
\hline $\begin{array}{l}\text { Comunicaçăo \& } \\
\text { Educaçăo }\end{array}$ & 3.782 & 4. 117 & 2.663 & 4.337 & 3.084 & 1.923 & 4.661 & 8.238 & 32.805 \\
\hline Revista FAMECOS & 1.923 & 2.296 & 1.186 & 2.973 & 2.426 & 1.893 & 3.381 & 6.428 & 22.506 \\
\hline Galáxia & 1.500 & 2.971 & 2.375 & 4.156 & 2.759 & 2.200 & 2.505 & 3.544 & 22.010 \\
\hline $\begin{array}{l}\text { Comunicação, Midia e } \\
\text { Consumo }\end{array}$ & 894 & 1.696 & 855 & 1.409 & 1.382 & 1.783 & 2.215 & 3092 & 13.326 \\
\hline Libero & 787 & 976 & 891 & 1.319 & 1.300 & 1.843 & 2.084 & 2.620 & 11.820 \\
\hline Em Questāo & 1.285 & 1.028 & 670 & 1.591 & 1.465 & 1.224 & 1.397 & 2.434 & 11.094 \\
\hline $\begin{array}{l}\text { Comunicaçäo \& } \\
\text { Sociedade }\end{array}$ & 717 & 668 & 638 & 1.271 & 1.139 & 1.483 & 1.771 & 2.127 & 9.814 \\
\hline Anagrama & $\ldots$ & - & _. & 125 & 966 & 1.559 & 2.508 & 3.436 & 8.594 \\
\hline $\begin{array}{l}\text { Estudios em Jomalismo } \\
\text { e Midia }\end{array}$ & 207 & 997 & 463 & 1.309 & 821 & 897 & 1.258 & 1.882 & 7.834 \\
\hline Fronteirgs & 655 & 715 & 545 & 1.028 & 967 & 670 & 1.155 & 2.018 & 7.749 \\
\hline Rastros & 494 & 512 & 580 & 1.291 & 762 & 473 & 819 & 1.218 & 6.149 \\
\hline Media e Jomalismo & 115 & 182 & 339 & 865 & 864 & 1.055 & 1.158 & 1436 & 6.014 \\
\hline Orgenicom & 349 & 301 & 340 & 624 & 325 & 427 & 623 & 505 & 3.494 \\
\hline Contracampo & 226 & 274 & 121 & 523 & 423 & 335 & 611 & 788 & 3.301 \\
\hline Verso e Roverso & 175 & 287 & 208 & 458 & 380 & 418 & 614 & 811 & 3.051 \\
\hline MATRIZES & 121 & 270 & 194 & 456 & 376 & 433 & 468 & 670 & 2.988 \\
\hline $\begin{array}{l}\text { Acenvo On-Line de } \\
\text { Midila Regional }\end{array}$ & 273 & 281 & 186 & 407 & 337 & 303 & 359 & 738 & 2.884 \\
\hline OBServalorio & 307 & 359 & 164 & 390 & 274 & 278 & 394 & 715 & 2.871 \\
\hline E-Com & 383 & 360 & 221 & 379 & 336 & 277 & 338 & 526 & 2.820 \\
\hline REBE $J$ & 117 & 191 & 152 & 284 & 319 & 320 & 214 & 321 & 1.918 \\
\hline Rumores & - & - & - & - & - & 2 & 16 & 793 & 811 \\
\hline TOTAL & 14.310 & 18.481 & 12.791 & 25.183 & 20.705 & 19.796 & 28.449 & 44.138 & 183.853 \\
\hline
\end{tabular}

Ilustração 2: Número de downloads do Portal Univerciencia.org por revista - dez. 2008/jul. 2009. ${ }^{22}$

${ }^{22}$ FERREIRA, Sueli Mara Soares Pinto; TARGINO, Maria das Graças. Métricas alternativas de avaliação do impacto e do uso de revistas eletrônicas: estudo em ciências da comunicação. In: FERREIRA, Sueli Mara Soares Pinto; TARGINO, Maria das Graças (orgs.). Acessibilidade e visibilidade de revistas científicas eletrônicas. São Paulo: Senac/CENGAGE, 2010. p. 47. 


\section{5 Permutas e doações}

\section{Permutas}

Desde sua criação, a revista constitui-se também em importante veículo de comunicação, intercâmbio e relacionamento com outras Faculdades e Universidades de ciências humanas e de comunicação. Uma demonstração desta troca de conhecimentos está na lista de permutas de suas edições com as publicações das seguintes instituições brasileiras e estrangeiras:

\section{Estrangeiras}

- Biblioteca-Hemeroteca da Universidad Pedagógica Nacional - Bogotá, Colômbia

- Centro de Documentaciòn - Depto de Estudios de la Comunicación Social Universidade de Guadalajara - Guadalajara, México

- Chasqui - Revista Latinoamericana de Comunicación - Centro Internacional de Estudios Superiores de Comunicación para América Latina (CIESPAL) - Quito, Ecuador

- Comunicar - Revista Científica Iberoamericana de Comunicación y Educación Grupo Comunicar - Colectivo Andaluz de Educación y Comunicación - Huelva, Espanha

- Inmediaciones de la Comunicación - Facultad de Comunicación y Diseño

- Revista Comunicación y Sociedad - Buenos Aires, Argentina

- Revista Contacto Directo - Facultad de Ciencias de la Comunicación - Universidad Privada Antenor Orrego (UPAO) - Trujillo, Peru

- Revista Convergencia - Universidad Autónoma del Estado de México, Toluca, México

- Revista Educación - Pontifícia Universidad Catolica del Peru - Lima, Peru

- Revista Espacio Aberto - Faculdade de Humanidades e Educação da Universidad del Zulia - Maracaibo, Venezuela

- Revista Quórum Acadêmico - Centro de Investigação da Comunicação e da Informação (CICI) da Faculdade de Humanidades e Educação da Universidad del Zulia - Maracaibo, Venezuela 
- Revista Tékhne - Instituto Politécnico do Cavado e do Ave (IPCA) - Barcelos, Portugal

- Revista Comunicación y Médios - Instituto de la Comunicación y Imagen de la Universidad de Chile - Santiago de Chile, Chile

\section{Brasileiras}

- Anima - Unidade Via Corpvs - Faculdade Integrada do Ceará (FIC) - Fortaleza, Ceará, Brasil

- Aprender - Caderno de Filosofia e Psicologia da Educação - Edições UESB (Universidade Estadual do Sudoeste da Bahia) - Itapetinga, BA, Brasil

- Cambiassu - Departamento de Comunicação Social da Universidade Federal do Maranhão (UFMA) - São Luís, Maranhão, Brasil

- Comunicação \& Tecnologia - Editora FUPAC (Fundação Presidente Antônio Carlos e UNIPAC - Universidade Presidente Antônio Carlos) - Barbacena, MG, Brasil

- Communicare - Biblioteca Prof. José Geraldo Vieira - Faculdade Cásper Líbero São Paulo, SP, Brasil

- Comunicarte - Instituto de Artes, Comunicações e Artes - Pontifícia Universidade Católica de Campinas (Puccamp) - Campinas, SP, Brasil

- Contemporaneum - Cadernos de Pós-graduação - Biblioteca Prof. Nicolass Gerardus Plasschaert - Fundação Educacional de Divinópolis da Universidade da Universidade do Estado de Minas Gerais (FUNEDI/UEMG) - Divinópolis, Minas Gerais, Brasil

- Em Questão - Faculdade de Biblioteconomia e Comunicação - Biblioteca Setorial Universidade Federal do Rio Grande do Sul (UFRGS) - Porto Alegre, RS, Brasil

- Estudos da Comunicação - Sistema Integrado de Bibliotecas - Pontifícia Universidade Católica do Paraná (PUCPR) - Curitiba, PR, Brasil

- Estudos Da Linguagem - Universidade Estadual do Sudoeste da Bahia (UESB) Itapetinga, BA, Brasil

- Filosofazer - Instituto Superior de Filosofia Berthier (IFIBE) - Passo Fundo, RS, Brasil

- Floema - Caderno de Teoria e História Literária - Universidade Estadual do Sudoeste da Bahia (UESB) - Itapetinga, BA, Brasil

- Kairós - Faculdade de Ciências Humanas e Saúde - Pontifícia Universidade Católica de São Paulo (PUC-SP) - São Paulo, SP, Brasil 
- Linguagem \& Ensino - Curso de Mestrado em Letras - Universidade Católica de Pelotas - Pelotas, RS, Brasil

- Rastros - Revista do Núcleo de Estudos em Comunicação - Núcleo de Estudos em Comunicação Social (NECOM) - Instituto Superior e Centro Educacional Luterano Bom Jesus (IELUSC) - Joinville, SC, Brasil

- Revista Brasileira de Estudos Pedagógicos - Instituto Nacional de Estudos e Pesquisas Educacionais Anísio Teixeira (INEP) - Brasília, DF, Brasil

- Revista de Ciências da Educação - Centro Universitário Salesiano de São Paulo (Unisal) - São Paulo, SP, Brasil

- Revista de Educação Pública - Centro de Tecnológicas e Documentação Educacionais (CETEDE) - Instituto de Educação da Universidade Federal de Mato Grosso (UFMT) - Cuiabá, MT, Brasil

- Revista de Estudos Universitários - Universidade de Sorocaba (Uniso) - Sorocaba, SP, Brasil

- Revista Famecos - Editora Universitária EDIPUCRS - Faculdade de Comunicação Social da Pontifícia Universidade Católica do Rio Grande do Sul (PUCRS) - Porto Alegre, RS, Brasil

- Trabalho, Educação e Saúde - Biblioteca Emília Bustamante - Escola Politécnica de Saúde Joaquim Venâncio - Fundação Oswaldo Cruz - Rio de Janeiro, RJ, Brasil

- Tradução e Comunicação - Revista Brasileira de Tradutores - Centro Universitário Ibero-americano - Unibero - Biblioteca Gilberto Freire - São Paulo, SP, Brasil

\section{Doações}

As doações de exemplares da revista são realizadas a partir de solicitações por escrito. Por meio desse sistema, a publicação está presente nas seguintes instituições do Brasil e exterior:

\section{Estrangeiras}

- Universitat Autònoma de Barcelona - Servei de Biblioteques - Intercanvi (Barcelona, Espanha)

- Universidad Santiago Cali - Biblioteca Santiago Cadena Copete (Cali, Colômbia)

- Red Iberoamericana de Revistas de Comunicación y Cultura (Buenos Aires, Argentina) 


\section{Brasileiras}

- Biblioteca Nacional (Rio de Janeiro, RJ, Brasil)

- Pontifícia Universidade Católica (São Paulo, SP, Brasil)

- Revista Latinoamericana de Ciencias de la Comunicación - ALAIC (São Paulo, SP, Brasil)

- Universidade de São Paulo - Instituto de Psicologia (São Paulo, SP, Brasil)

- Comitê Gestor da Internet no Brasil (São Paulo, SP, Brasil)

- Universidade Luterana do Brasil - ULBRA (Canoas, RS, Brasil)

- Universidade Cidade de São Paulo - Unicid (São Paulo, SP, Brasil)

- Centro Universitário Nove de Julho - Uninove (São Paulo, SP, Brasil)

- Universidade Ibirapuera (São Paulo, SP, Brasil)

- Universidade São Judas Tadeu - USJT (São Paulo, SP, Brasil)

- Universidade São Marcos (São Paulo, SP, Brasil)

- Organização não-governamental de Promoção Social JAE - Juventude Associada de Eugenópolis (Eugenópolis, MG, Brasil)

- Secretaria Municipal de Educação (São Paulo, SP, Brasil)

- Universidade do Sagrado Coração - USC (Bauru, SP, Brasil)

- Senado Federal (Brasília, DF, Brasil)

- Instituto Fernand Braudel de Economia Mundial (São Paulo, SP, Brasil)

- Museu de Arte Contemporânea (São Paulo, SP, Brasil)

- Centro Dragão do Mar Arte e Cultura (Fortaleza, CE, Brasil)

- Escola Superior de Administração, Marketing e Comunicação de Uberlândia ESAMC (Uberlândia, MG, Brasil)

- Universidade Católica de Pernambuco (Recife, PE, Brasil)

- Universidade do Estado do Rio Grande do Norte - Programa de Pós-Graduação em Letras - PPGL (Mossoró, RN, Brasil)

- Universidade Federal de Campina Grande (Campina Grande, PB, Brasil)

- Centro Pastoral Educacional e Assistencial Dom Carlos - CPEA (Palmas, PR, Brasil)

- Universidade Federal de Lavras (Lavras, MG, Brasil)

- Universidade de Taubaté - UNITAU (Taubaté, SP, Brasil)

- Faculdade São Geraldo (Cariacica, ES, Brasil)

- Faculdade de Tecnologia de Jundiaí - Centro de Educação Estadual Paula

Souza (Jundiaí, SP, Brasil)

- Polícia Militar do Estado de São Paulo (São Paulo, SP, Brasil) 
- Faculdade do Sul da Bahia - FASB (Teixeira de Freitas, BA, Brasil)

- Pontifícia Universidade Católica de Minas Gerais (Belo Horizonte, MG, Brasil)

- Pontifícia Universidade Católica de Minas Gerais - Campus de Poços de Caldas (Poços de Caldas, MG, Brasil)

- Universidade Federal da Grande Dourados - UFGD (Dourados, MS, Brasil)

\section{6 Definição do perfil editorial}

Uma das especificidades de Comunicação \& Educação é trazer, ao lado dos artigos que refletem pesquisas na área, também conteúdo voltado à prática ou em formato jornalístico - entrevistas, críticas, depoimentos, indicações de links na internet e, inclusive, uma seção de poesia voltada ao trabalho nos espaços comunicativos ou educativos.

Ao contrário de alguns dos outros periódicos científicos, Comunicação \& Educação não é uma simples reunião de ensaios; tem uma estrutura complexa, com diversas seções, cada uma com um perfil editorial, uma finalidade, um trabalho de pesquisa, uma forma de diálogo com o leitor. Cada seção tem sua especificidade - para Artigos Nacionais, muitos originais são recebidos, lidos, comentados pelos pareceristas, retornando, por vezes, ao autor para necessários ajustes. Essa triagem faz com que possamos divulgar sempre temas novos, atualizados, pertinentes e sérios. ${ }^{23}$

A opção por esse modelo editorial foi sustentada de forma proposital, trazendo tanto vantagens quando estranhamento inicial, como explica Costa:

O hibridismo da revista é um calcanhar de Aquiles. Muitas vezes fomos cobrados por não fazermos uma revista científica, ou seja, sem preocupação conceitual. Mas existem várias maneiras de construir um conceito, e não necessariamente só através de teoria - mas também do movimento da prática. É uma opção que temos nos recusado a

\footnotetext{
${ }^{23}$ COSTA, Cristina. Dificuldades e prazeres de uma publicação. Comunicação \& Educação, ano 15, n.
} 1, 2010. pp. 7-8. 
modificar, porque a pressão é para que a revista fique cada vez mais acadêmica, mais formal, rigorosa, dar voz àquelas pessoas que sempre tiveram voz. Mas, dentro do possível, temos procurado ser fiéis a nosso propósito. $^{24}$

Buscando trabalhar sempre com textos inéditos, Comunicação \& Educação não possui números temáticos, sendo sua pauta definida de acordo com o fluxo das colaborações recebidas. Por vezes, especialistas são chamados a discutir temas específicos definidos pela comissão editorial.

\section{Seções}

Comunicação \& Educação foi dividida em seções que refletem o caráter transdisciplinar das áreas que discute. Atualmente, o conteúdo da revista é distribuído em Editorial, Apresentação, Artigos Nacionais, Artigos Internacionais, Gestão da Comunicação, Depoimento, Entrevista, Crítica, Experiência, Poesia, Resenhas e Atividades em Sala de Aula.

O Editorial e a Apresentação abrem cada novo número da revista. Normalmente, as duas seções trazem o ponto de vista da comissão editorial sobre os temas apresentados, além de elencar os principais assuntos da edição. A seção de Artigos Nacionais, por sua vez, traz a visão de comunicadores, pesquisadores e educadores brasileiros a respeito de temas relacionados ao espaço comunicação/educação. Já os estudos e reflexões produzidos no exterior, de repercussão internacional, fazem parte da seção de Artigos Internacionais - que conta, em alguns números, com trabalhos publicados na revista Communication Research Trends, editada pelo Centre for the Study of Communication and Culture da Universidade Saint Louis, EUA - traduzidos com exclusividade para a língua portuguesa.

As seções de caráter jornalístico da revista são representadas por quatro diferentes seções: Entrevista - na qual profissionais, professores e pesquisadores de destaque nas áreas de comunicação e educação falam sobre seu trabalho e referências;

\footnotetext{
${ }^{24}$ Entrevista concedida pela professora Maria Cristina Castilho Costa em 10.01.2012, em São Paulo/SP.
} 
Crítica - trazendo análises opinativas sobre a produção dos meios de comunicação de massa; Depoimento - na qual personalidades, artistas ou profissionais representativos nas áreas de propaganda, televisão, rádio, dramaturgia, imprensa ou literatura falam sobre sua carreira e história; e Resenhas - em que professores ou especialistas em áreas como audiovisual, dramaturgia, comunicação, educação e literatura analisam obras específicas.

A aplicabilidade dos conceitos teóricos é destaque das seções Experiência - em que professores e educadores relatam atividades na interface comunicação/educação realizadas em sala de aula ou em instituições de educação não-formal - e Gestão, criada para dar visibilidade aos projetos de destaque ligados ao curso de pós-graduação dentro do qual nasceu a revista.

A seção Poesia, por sua vez, traz e analisa a produção poética de importantes escritores brasileiros, incentivando os educadores a utilizá-los em suas atividades. Por fim, a seção Atividades em Sala de Aula sintetiza um dos princípios da publicação, que é o de sugerir atividades práticas baseadas nos temas abordados na edição. A escolha de uma autora da área de ciências exatas como colaboradora fixa desta seção - a professora Ruth Ribas Itacarambi, educadora aposentada do Instituto de Matemática e Estatística da USP (IME/USP) e pesquisadora e professora das Faculdades Osvaldo Cruz - reflete o desejo de reforçar a multidisciplinaridade e o diálogo da revista com os diferentes campos do saber. Em suas palavras:

Esse trabalho é guiado por uma proposta pedagógica, que é a proposta de Paulo Freire. Poderíamos ter várias propostas pedagógicas - uma mais tecnicista, outra mais construtivista, mas nesse caso preferimos uma proposta dialógica. A idéia das atividades é fazer um paralelo com o diálogo, sem que isso seja algo impositivo. Temos, por exemplo, cuidado com os verbos: "propomos, orientamos, sugerimos". Deixamos que o professor escolha o momento mais adequado de aplicar as ações em sala de aula. ${ }^{25}$

\footnotetext{
${ }^{25}$ Entrevista concedida pela professora Ruth Ribas Itacarambi em 26.01.2012, em São Paulo/SP.
} 
Ao longo da trajetória da revista, as seções foram também sendo revisitadas e reformuladas de acordo com a necessidade dos campos. As seções Referências Bibliográficas e Videografia, por exemplo, a partir do ano de 2012 deram origem à seção Resenhas, focada na análise de obras artísticas ou comunicacionais diversas; também as seções Serviços - criada para indicar experiências ou organizações ligadas à área educacional - e Endereços úteis na internet - trazendo links de páginas de interesse ligadas à comunicação e educação - foram criadas por necessidade de acompanhar as tendências do trabalho e da discussão dos temas em determinados períodos, sendo substituídas por outras conforme a evolução das discussões.

\section{Análise editorial inicial}

Ao início da presente pesquisa, eram de conhecimento do Departamento de Comunicações e Artes alguns dados que mostram o perfil e a evolução da revista durante sua primeira década. Durante este período - assim como nos subsequentes - a seção de Artigos Nacionais tem predominância em volume de textos publicados, correspondendo a 79,8\% do volume total de textos entre 1994 e $2003 .{ }^{26}$

Segue a relação de chamadas de capa dos números já publicados, evidenciando o histórico de temas tratados pela revista:

$\boldsymbol{n}^{\circ} \mathbf{1}$, ano I, setembro/dezembro 1994 - Leitura crítica da comunicação

$\boldsymbol{n}^{\circ}$ 2, ano I, janeiro/abril 1995 - Jornal Eletrônico; Televisão educativa; Comunicação e LDB

$n^{\circ}$ 3, ano I, maio/agosto 1995 - Ensino a distância; Educação e cidadania; Telenovela, ficção e história

$\boldsymbol{n}^{\circ}$ 4, ano II, setembro/dezembro 1995 - Cinema e Carla Camurati; Imprensa e petroleiros; Telenovela e Lauro César Muniz

n5, ano II, janeiro/abril 1996 - Agências de notícias; Educação a distância; Imprensa: um dilema ético

n6, ano II, maio/agosto 1996 - Projeto TV Escola; Educação na internet; Rádio:

${ }^{26}$ PIRES, Suzana Simões Ribeiro. Comunicação \& Educação - novas propostas de gestão da comunicação. 2005. Dissertação (Pós-graduação em Gestão de Processos Comunicacionais) Departamento de Comunicações e Artes da Escola de Comunicações e Artes da Universidade de São Paulo. p. 24. 
presença cotidiana

$n^{\circ}$ 7, ano III, setembro/dezembro 1996 - Televisão e criança; O humor da charge política; Jânio de Freitas: jornalista

n'8, ano III, janeiro/abril 1997 - Educação e exclusão; Violência e política na TV; Videogame e os discursos não-didáticos

n9, ano III, maio/agosto 1997 - Comunicação plural; Em cena - José Wilker; Multimeios e cidadania

$\boldsymbol{n}^{\circ}$ 10, ano IV, setembro/dezembro 1997 - Guillermo Orozco; História e imagem; No tempo da TV artesanal

$\boldsymbol{n}^{\circ} \mathbf{1 1}$, ano IV, janeiro/abril 1998 - TV Cultura; J. Martín-Barbero; Conhecimento e informação

$\boldsymbol{n}^{\circ}$ 12, ano IV, maio/agosto 1998 - Frida Kahlo, Estudos de recepção; Uma pedagogia para os meios

$n^{\circ}$ 13, ano V, setembro/dezembro 1998 - Multiculturalismo; Comunicação no Mercosul; Telenovela: arte do cotidiano

$\boldsymbol{n}^{\circ} \mathbf{1 4}$, ano V, janeiro/abril 1999 - Arte-educação; Internet no ensino; Tecnologia e sociabilidade

$n^{\circ}$ 15, ano V, maio/agosto 1999 - Educação e cidadania; Tecnologia, imagem e escola; Sujeito, comunicação e cultura

$\boldsymbol{n}^{\circ}$ 16, ano VI, setembro/dezembro 1999 - Armand Mattelart; Rádio na era digital; Escola: ciência e tecnologia

$\boldsymbol{n}^{\circ} 17$, ano VI, janeiro/abril 2000 - Discurso da propaganda; Telenovela: nova linguagem; Comunicação e práticas escolares

$n^{\circ} \mathbf{1 8}$, ano VI, maio/setembro 2000 - Identidades e globalização; Novas tecnologias na escola; Rádio a serviço da comunidade

$n^{\circ}$ 19, ano VII, setembro/dezembro 2000 - Educomunicação: um campo de mediações; Ação política e propaganda eleitoral: instrumentos da democracia; Propaganda eleitoral, jornalismo e construção da agenda pública (Entrevista com Luís Gonzalez) $\boldsymbol{n}^{\circ}$ 20, ano VII, janeiro/abril 2001 - As mediações e a perspectiva do receptor; Comunicação na União Européia; Trabalho e educação a distancia $\boldsymbol{n}^{\circ}$ 21, ano VII, maio/agosto 2001 - Teatro brasileiro; Escola e televisão; Educação para os meios

$\boldsymbol{n}^{\circ}$ 22, ano VIII, setembro/dezembro 2001 - Comunicação: identidade e identidades em Portugal; Futuros e utopias da Modernidade; História em quadrinhos 
$\boldsymbol{n}^{\circ}$ 23, ano VIII, janeiro/abril 2002 - Política cultural na contemporaneidade; Violência e globalização; Jornal, jogos e brincadeiras

$\boldsymbol{n}^{\circ} \mathbf{2 4}$, ano VIII, maio/agosto 2002 - TV, criança e violência; Representação e imagem; Arte em São Paulo

$\boldsymbol{n}^{\circ}$ 25, ano IX, setembro/dezembro 2002 - Educação, máquinas e redes; Cinema, vídeo e televisão; Ensino e arte

$\boldsymbol{n}^{\circ}$ 26, ano IX, janeiro/abril 2003 - Telenovela e identidades sociais; Educação a distância; Tecnologia digital

$\boldsymbol{n}^{\circ} 27$, ano IX, maio/agosto 2003 - Material educativo: a experiência de aprendizado; Receptores mais críticos, TV de melhor qualidade; Filosofia de Paulo Freire e práticas cognitivas no Jornalismo.

A partir de 2005, atendendo a demandas normativas da Coordenação de Aperfeiçoamento de Pessoal de Nível Superior (CAPES), órgão do Governo Federal ligado ao Ministério da Educação, a numeração das revistas foi reiniciada e suas capas passaram a contar com uma manchete principal, seguida de três ou quatro chamadas menores. Seguem as chamadas principais dos números seguintes:

$\boldsymbol{n}^{\circ} \mathbf{1}$, ano X, janeiro/abril 2005 - A Casa de Detenção

$\boldsymbol{n}^{\circ} \mathbf{2}$, ano X, maio/agosto 2005 - Heródoto Barbeiro

$\boldsymbol{n}^{\circ} \mathbf{3}$, ano X, setembro/dezembro 2005 - Dez anos de Comunicação \& Educação

$\boldsymbol{n}^{\circ} \mathbf{1}$, ano XI, janeiro/abril 2006 - Gestão da Comunicação

$\boldsymbol{n}^{\circ} \mathbf{2}$, ano XI, maio/agosto 2006 - Elifas Andreato

$\boldsymbol{n}^{\circ}$ 3, ano XI, setembro/dezembro 2006 - Guillermo Orozco Gómez

$\boldsymbol{n}^{\circ} \mathbf{1}$, ano XII, janeiro/abril 2007 - Comunicação e memória em tempos de repressão

$\boldsymbol{n}^{\circ} \mathbf{2}$, ano XII, maio/agosto 2007 - Entrevistando Cao Hamburguer

$\boldsymbol{n}^{\circ}$ 3, ano XII, setembro/dezembro 2007 - A África no cinema e nos currículos escolares $n^{\circ} \mathbf{1}$, ano XIII, janeiro/abril 2008 - O trânsito entre culturas e as práticas de comunicação e educação

$\boldsymbol{n}^{\circ} \mathbf{2}$, ano XIII, maio/agosto 2008 - Imprensa e ideologia: a cobertura do governo brasileiro pelos jornais britânicos

$\boldsymbol{n}^{\circ}$ 3, ano XIII, setembro/dezembro 2008 - Bicentenário da imprensa desafia sociedade a promover inclusão cognitiva

$\boldsymbol{n}^{\circ} \mathbf{1}$, ano XIV, janeiro/abril 2009 - O cotidiano revelado na poesia de Adélia Prado 
$\boldsymbol{n}^{\circ}$, ano XIV, maio/agosto 2009 - Conflitos internacionais: o jornalismo de Kapuscinski

$\boldsymbol{n}^{\circ} \mathbf{3}$, ano XIV, setembro/dezembro 2009 - USP: uma licenciatura para a Educomunicação

$\boldsymbol{n}^{\circ} \mathbf{1}$, ano XV, janeiro/abril 2010 - Linguagens da comunicação e desafios educacionais $\boldsymbol{n}^{\circ} 2$, ano XV, maio/agosto 2010 - Comunicação e escola: pesquisando jovens professores

$\boldsymbol{n}^{\circ}$ 3, ano XV, setembro/dezembro 2010 - Banda larga e TV digital no Brasil $\boldsymbol{n}^{\circ} \mathbf{1}$, ano XVI, janeiro/junho 2011 - Televisão e educação: Novos formatos, novos profissionais

$\boldsymbol{n}^{\circ} \mathbf{2}$, ano XVI, julho/dezembro 2011 - Meios públicos e alternativos para a democracia participativa $\boldsymbol{n}^{\circ} \mathbf{1}$, ano XVII, janeiro/junho 2012 - Roland Barthes e o signo fotográfico

Com base na observação desta relação, e de acordo com uma análise dos temas abordados pela revista, percebe-se grande ênfase, durante os primeiros anos da publicação, ao tema audiovisual - à época um dos recursos de comunicação mais presentes no cotidiano dos alunos, constituindo-se, portanto, num dos principais desafios aos educadores, que perfaziam uma reflexão constante a respeito de suas potencialidades, pontos negativos e benefícios. Ao longo da trajetória revista, o tema foi dando lugar a outros, a exemplo dos meios de comunicação digitais e novas mídias, como veremos na análise dos artigos a partir da segunda década de sua existência.

\section{7 Identidade gráfica}

Conforme o desenrolar da história da revista e suas diferentes parcerias editoriais, também o aspecto gráfico da publicação passou por modificações. Seu layout inicial foi escolhido por meio de concurso promovido entre os alunos da USP, com participação de todas as unidades, tendo o projeto vencedor sido proposto por estudantes da Faculdade de Arquitetura e Urbanismo (FAU/USP). Podemos observar que os logotipos da USP, ECA e CCA são destacados na parte esquerda da revista, estabelecendo relação direta entre as instituições e a publicação. 


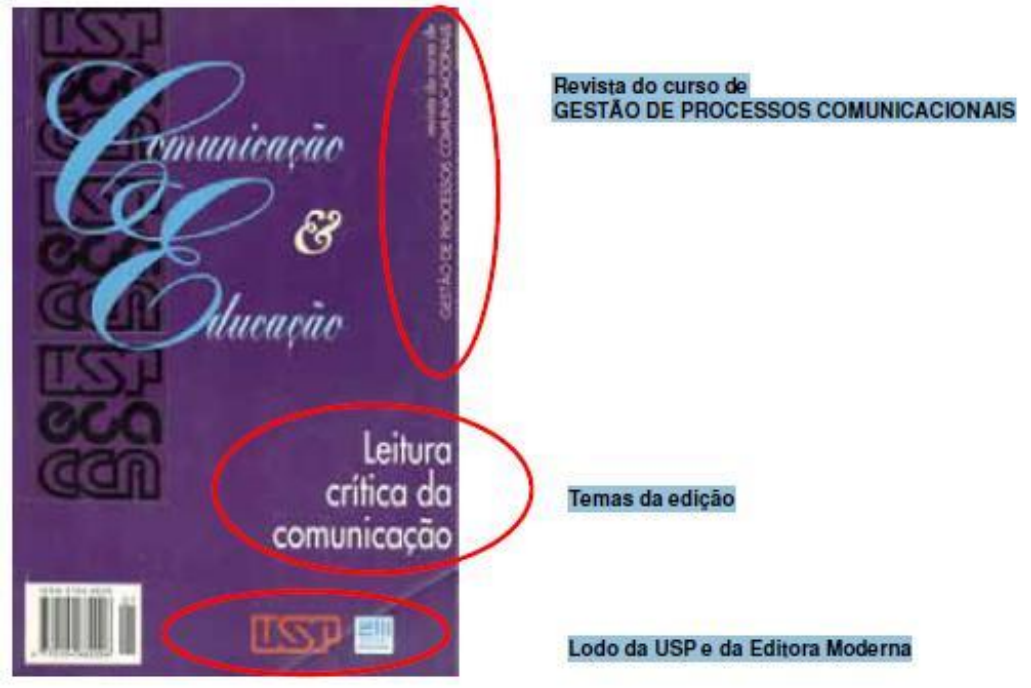

Variaçōes de cores (número 2 ao número 10)
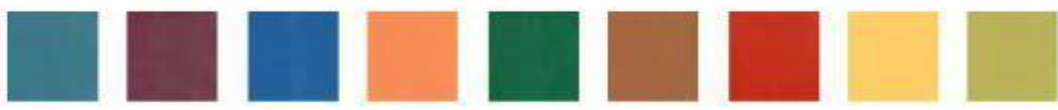

Ilustração 4. Capa do primeiro número da revista Comunicação \& Educação ${ }^{27}$

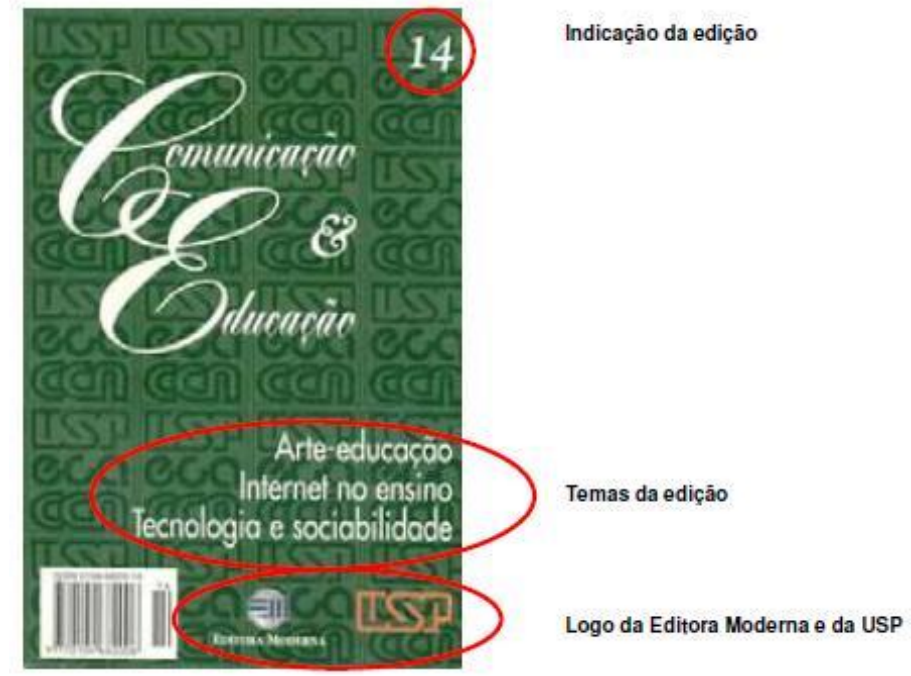

Variaçōes de cores ( do número 11 ao número 15)
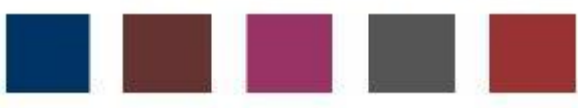

Ilustração 5. Projeto gráfico da revista do número 11 ao $15^{28}$

27 PIRES, Suzana Simões Ribeiro. Comunicação \& Educação - novas propostas de gestão da comunicação. 2005. Dissertação (Pós-graduação em Gestão de Processos Comunicacionais) Departamento de Comunicações e Artes da Escola de Comunicações e Artes da Universidade de São Paulo. p. 18.

${ }^{28}$ Idem. p. 19. 
A partir da edição de número 11, as marcas da USP, da ECA e do Departamento de Comunicações e Artes (CCA) passaram a integrar, no plano de fundo, toda a capa da revista. O logotipo da Editora também foi modificado e reorganizado graficamente em relação ao logotipo da USP.

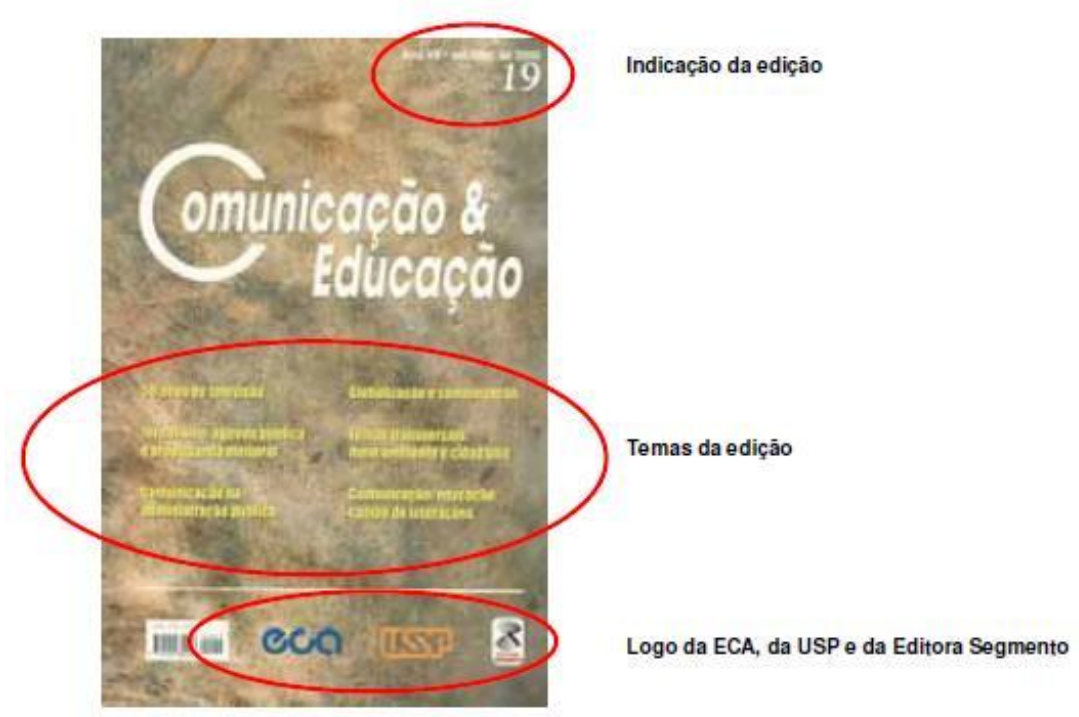

Ilustração 6. Projeto gráfico da revista a partir do número $19^{29}$

Do número 19 em diante, já em parceria com a Editora Segmento, o layout passou por mudanças mais significativas - envolvendo a fonte utilizada no logotipo da revista, o uso de duas cores na capa e a uma nova organização gráfica da relação dos temas presentes em cada número. A ECA passou a assinar a publicação juntamente com a USP e a editora parceira.

Novamente, o layout da revista foi modificado em 2005, quando esta passou a ser editada pela Editora Paulinas após uma pausa de 17 meses. A numeração dos exemplares foi, nesta ocasião, retomada a partir do número 1, conforme normativa da CAPES. Elaborada pela Midiamix Editora Ltda. - empresa gerida por Ebenezer de Menezes, ex-aluno do curso de Gestão da Comunicação - a nova proposta gráfica buscou um padrão que pudesse tornar a leitura mais agradável, utilizando recursos normalmente usados em revistas comerciais, como os títulos em colunas verticais e a maior incidência de espaços em branco.

\footnotetext{
${ }^{29}$ PIRES, Suzana Simões Ribeiro. 2005. Dissertação (Pós-graduação em Gestão de Processos Comunicacionais) - Departamento de Comunicações e Artes da Escola de Comunicações e Artes da Universidade de São Paulo. p. 21.
} 


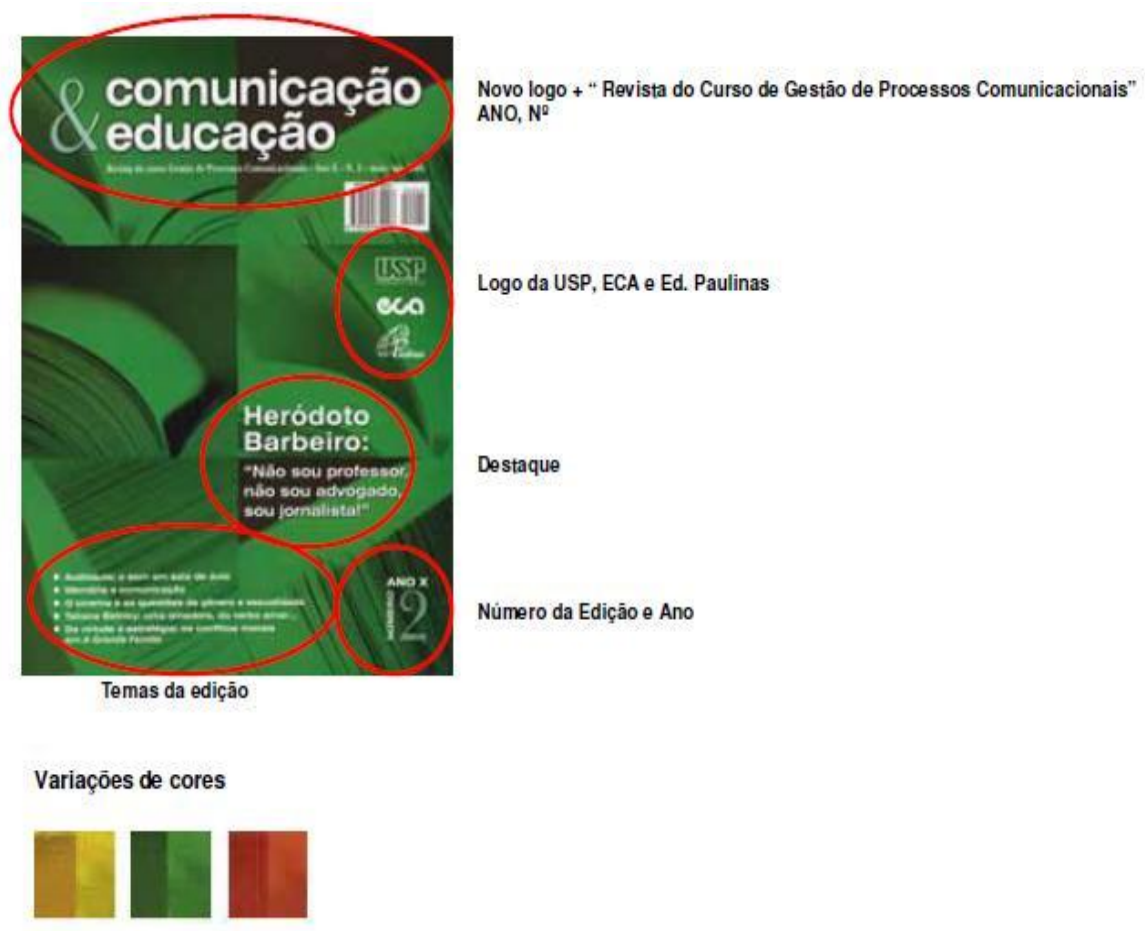

Ilustração 7. Projeto gráfico da revista Comunicação \& Educação a partir do número $28^{30}$

A partir de 2009, a revista assumiu a aparência gráfica atual, com base em novo projeto gráfico criado pela Midiamix Editora: as fontes do título e das chamadas foram revistas e escolhidos quatro assuntos constantes da edição para receberem destaque na capa, um deles em manchete. Outros elementos gráficos, como os logotipos das instituições parceiras e o número indicativo da edição, foram realocados, além da própria imagem de fundo ter sido reformulada.

Atualmente, a revista circula no tamanho de $21,0 \mathrm{~cm}$ x $28,0 \mathrm{~cm}$ (formato final fechado e refilado), com capa em quatro cores em papel supremo $250 \mathrm{~g}$ com plastificação. Seu miolo é impresso em duas cores, em papel off-set $75 \mathrm{~g}$. Possui acabamento em costura e brochura e uma média de 150 páginas por número.

\footnotetext{
${ }^{30}$ PIRES, Suzana Simões Ribeiro (2005). 2005. Dissertação (Pós-graduação em Gestão de Processos Comunicacionais) - Departamento de Comunicações e Artes da Escola de Comunicações e Artes da Universidade de São Paulo. p. 23.
} 


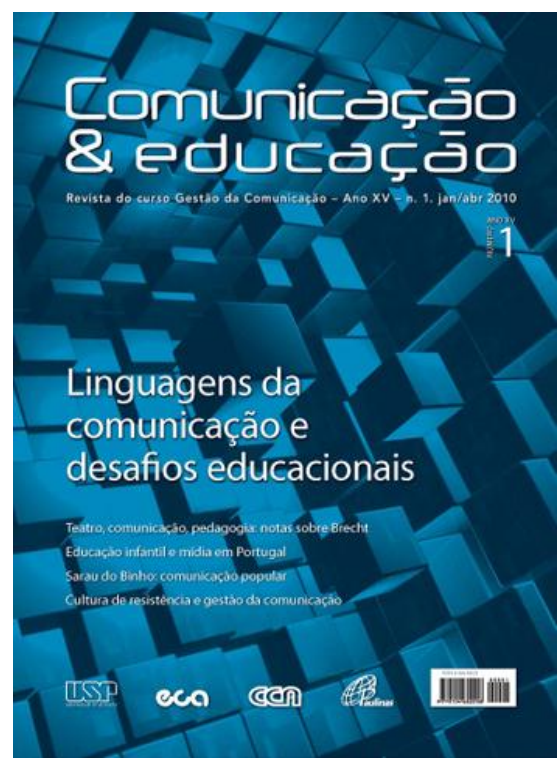

Ilustração 8. Projeto gráfico atual de Comunicação \& Educação

\subsection{Avaliação QUALIS e credenciamento USP}

A produção nacional de publicações acadêmicas é regulada pela Lei Nacional de Diretrizes e Bases (LDB) de 20 de dezembro de 1996, que prevê em seu Capítulo IV, Artigo 43, parágrafo III, que a educação superior tem por finalidade incentivar $o$ trabalho de pesquisa e investigação científica, visando o desenvolvimento da ciência, da tecnologia e da criação e difusão da cultura, e, desse modo, desenvolver o entendimento do homem e do meio em que vive. No parágrafo seguinte, a Lei estabelece que as instituições de ensino devem promover a divulgação de conhecimentos culturais, científicos e técnicos que constituem patrimônio da humanidade e comunicar o saber através do ensino, de publicações ou de outras formas de comunicação. ${ }^{31}$

A avaliação dos cursos de pós-graduação stricto sensu em todos os estados do país é uma atribuição da Coordenação de Aperfeiçoamento de Pessoal de Nível Superior (CAPES), realizada com o objetivo de manter o padrão nacional de excelência acadêmica. Em 2001, a CAPES lançou o portal Periódicos (www.periodicos.capes.gov.br), disponibilizando um acervo de aproximadamente dez mil revistas nacionais e internacionais, além de dezenas de bases de dados com resumos

\footnotetext{
${ }^{31}$ Lei Nacional de Diretrizes e Bases (LDB). Disponível em http://portal.mec.gov.br/arquivos/pdf/ldb.pdf. Acesso em 05.05.2012.
} 
de documentos em todas as áreas do conhecimento e fontes de informação de acesso gratuito via internet.

Todas as publicações listadas no portal foram avaliadas de acordo com o critério QUALIS, estabelecido pela CAPES - prevendo, entre outras coisas, a publicação de artigos de professores, pesquisadores ou alunos de programas de pós-graduação avaliados pela própria Coordenação. A avaliação QUALIS, realizada anualmente, classifica os trabalhos publicados pelos docentes com base nas informações fornecidas pelos programas, por meio do sistema de coleta de dados, e avaliadas por comissões de consultores especializados nas diversas áreas do conhecimento. A partir desses dados, as diversas publicações são enquadradas em estratos indicativos de qualidade - A1, o mais elevado; A2; B1; B2; B3; B4; B5; e C, com peso zero. ${ }^{32}$ Somente constam do portal Periódicos as publicações com nota "A" ou "B".

Avaliada dentro da área de Ciências Sociais Aplicadas, Comunicação \& Educação possui atualmente a classificação B. Em sua última avaliação, obteve nota "B2”. Citelli considera este resultado como fruto de uma escolha editorial da própria comissão criadora da revista:

\begin{abstract}
A revista é B2, mas poderia ser $B 1$ ou superior, se alterássemos um pouco sua rota editorial. E teríamos plenas condições de fazê-lo, pois a revista tem estrutura para isso. Mas seguimos um projeto políticoeditorial que contempla o diálogo com um universo profissional, social e cultural maior do que aquele estrito ao mundo da universidade, da pósgraduação, etc. Até porque já há muitas revistas, mesmo na área de comunicação, que se pretendem ou são acadêmicas. Dessa forma, preferimos preservar as características originais da publicação. ${ }^{33}$
\end{abstract}

Ao lado desta análise, e de acordo com Costa, constar da avaliação QUALIS foi também um esforço fundamental à própria constituição da revista, ajudando-a a se

\footnotetext{
${ }^{32}$ Informações disponíveis em http://www.capes.gov.br/servicos/sala-de-imprensa/36-noticias/2550capes-aprova-a-nova-classificacao-do-qualis. Acesso em 05.05.2012. A definição detalhada dos estratos qualificativos do QUALIS pode ser acessada no endereço http://www.anped.org.br/docs_capes/definicao_estratos_290908.pdf. Acesso em 23.07.2012.

${ }^{33}$ Entrevista concedida pelo professor Adilson Citelli em 12.01.2012, em São Paulo/SP.
} 
aproximar, com sua linha editorial particular, também do diálogo com a comunidade acadêmica. É resultado, ainda, da construção de uma relação de proximidade crescente com os leitores, atestada por outras pesquisas, como afirma Soares:

\begin{abstract}
É importante ressaltar que essa coerência foi sentida também pelo público leitor, que acabou por fazer uso constante da revista em seus estudos e na preparação de suas dissertações e teses. Foi o que constatou a pesquisa $\mathrm{O}$ campo da comunicação e suas referências: experimento metodológico para a produção de indicadores bibliométricos (2009), coordenada por Margarida M. Krunsch, ao identificar a revista Comunicação \& Educação como a mais referendada, dentre as revistas brasileiras, em pesquisas acadêmicas no campo da comunicação em 2004, mantendo-se entre as três primeiras até o presente momento. ${ }^{34}$
\end{abstract}

Além de contribuir de forma decisiva na construção do espaço para a discussão da interface entre a comunicação e a educação, a revista também influenciou o próprio andamento da estrutura de estudo e ensino das duas áreas, como veremos a seguir. Nas palavras de Baccega:

A revista realmente foi a mais forte responsável pela implantação dos estudos de comunicação e educação no Brasil. Nós avançamos muito nesse campo. Ainda falta muito, mas acho que a revista dá esse enorme orgulho para nós, para o curso de Gestão. A nova graduação do Departamento, inclusive, advém dos resultados dessa revista. Plantamos um projeto que deu frutos, com qualidade e originalidade. E veio esse curso, que eu gostaria muito que existisse por bastante tempo, e as pessoas começassem compreender realmente do que estamos falando. ${ }^{35}$

\footnotetext{
${ }^{34}$ SOARES, Ismar de Oliveira. A contribuição da revista Comunicação \& Educação para a criação da Licenciatura em Educomunicação. Comunicação \& Educação, ano 14, n. 3. São Paulo, ECA/USP, 2009. p. 17.

${ }^{35}$ Entrevista concedida pela professora Maria Aparecida Baccega em 27.04.2012, em São Paulo/SP.
} 


\subsection{A revista e o curso de Licenciatura em Educomunicação}

Com base no perfil descrito acima, pode-se concluir que a revista Comunicação \& Educação, a partir das discussões propostas a cada edição e do espaço estabelecido para a reflexão e o diálogo entre os campos, contribuiu também para o fortalecimento do conceito de Educomunicação, do qual trataremos à frente, e caracterizado pela interface entre os campos da comunicação e da educação.

A criação do curso de Licenciatura em Educomunicação, cuja primeira turma iniciou as aulas em fevereiro de 2011, é resultado de um projeto pedagógico já intentado pelo Departamento de Comunicações e Artes há cerca de duas décadas, nascido em conjunto com o curso de pós-graduação em Gestão da Comunicação e com a própria revista Comunicação \& Educação.

Havia, sim, o desejo de criar o que seria uma licenciatura ou um bacharelado com o tempo. Chegamos a encaminhar projetos entre a data de criação da revista e a aprovação do curso de Educomunicação. Eles tinham o título, naquele momento, de Comunicação e Educação absolutamente conectado com o título da revista. A palavra Educomunicação veio a posteriori. As pessoas que criaram o curso de Educomunicação são pessoas que vêm, nesses 20 anos, trabalhando no sentido de colocar o debate sobre as relações de comunicação e educação num patamar que, obviamente, transcende as questões afeitas às tecnologias, de mediações tecnológicas. Essa perspectiva nos acompanhou desde a criação da revista: a linha de traduzir as relações entre comunicação e educação num terreno mais ligado à cultura, às relações sociais, aos novos sensórios. É uma tendência que se manteve dentro do Departamento. ${ }^{36}$

O fortalecimento da discussão sobre a interface entre a comunicação e a educação, ao longo dos anos, criou condições propícias para que, finalmente, fosse concretizado o projeto inicial de estruturação do curso. Iniciativas de trabalho conjunto

\footnotetext{
${ }^{36}$ Entrevista concedida pelo prof. Adilson Citelli em 12.01.2012, em São Paulo/SP.
} 
entre os dois campos, tanto do ponto de vista das políticas públicas como de organizações da sociedade civil, tornaram mais natural a percepção geral da sociedade a respeito da existência de um profissional com formação específica, capacitado a compreender as singularidades desta área de interface.

Dessa forma, entrou em atividade, a partir de 2011, a primeira turma do curso de Licenciatura em Educomunicação da Escola de Comunicações de Artes da USP. A iniciativa soma-se a outro curso de graduação especificamente voltado à Educomunicação existente no país - o curso de Bacharelado em Educomunicação, organizado em 2010 pela Universidade Federal de Campina Grande, no estado da Paraíba.

No curso ministrado na ECA/USP, e organizado com a colaboração da Faculdade de Educação da USP, optou-se pela modalidade de Licenciatura com o objetivo de formar profissionais que possam atuar em ambientes envolvendo tanto o ensino formal como não formal, sejam eles escolas, ONGs ou diferentes espaços de mídia - em atividades ligadas ao magistério, à consultoria de projetos educomunicativos ou à pesquisa de temas relacionados à interface comunicação/educação/tecnologias da informação. Para completar a formação dos alunos, o curso prevê, além das atividades acadêmicas, também o acompanhamento de projetos que tenham a Educomunicação como referencial teórico-metodológico. Os egressos do curso estarão também habilitados à prática docente, como professores de comunicação para o Ensino Médio, assim como para o exercício de consultorias junto aos órgãos governamentais, à mídia, ao sistema educacional (fundamental, médio e superior) e ao terceiro setor, em programas e projetos relacionados às diferentes interfaces entre comunicação, tecnologias de informação e educação.

O curso já nasceu com uma relação de 4.3. candidatos por vaga na seleção promovida pela Fundação Universitária para o Vestibular (FUVEST) - a segunda maior correlação candidato/vaga na modalidade das Licenciaturas fornecidas pela USP. Ao analisar o perfil e os interesses dos estudantes e docentes, nota-se que coincidem com os temas tratados pela revista Comunicação \& Educação - e é, precisamente, para estes profissionais que a revista hoje produz conhecimento e abre espaço de reflexão. Agora com periodicidade semestral, ela tem papel estratégico, também, como material de 
apoio às disciplinas da Licenciatura, sempre reforçando a convergência entre as diversas áreas do saber em uma discussão conjunta.

Se observarmos o curso, veremos que está fortemente ancorado em algo que poderíamos, genericamente, chamar de áreas de formação geral sociabilidade, sociologia, antropologia, não necessariamente com esses títulos, mas espalhadas pelo currículo. Então, imaginamos que essa nova licenciatura se coloque numa perspectiva maior, mais humanista, mais indagativa sobre a natureza das técnicas, sobre o sentido da inclusão dessas técnicas e desses temas de representação social, como no caso da educação. É isso que anima a criação do curso de Educomunicação nos termos em que ele está organizado. ${ }^{37}$

\section{FORMULAÇÃO DO PROBLEMA DA PESQUISA}

Este breve histórico sintetiza o objeto de estudo e as principais informações disponíveis durante a preparação para a pesquisa. A partir desses dados, pretende-se mostrar como a revista reflete a evolução e fundamentação da interface entre a comunicação e a educação - sendo ela, como mostram as estatísticas, uma das publicações mais lembradas pelos pesquisadores e uma das principais referências teóricas para o trabalho envolvendo os dois campos.

Dessa forma, a análise da publicação e do desenvolvimento dos temas nela tratados, neste trabalho, está relacionada à observação, em grande medida, do próprio desenvolvimento da relação entre comunicação e educação - e, especialmente, da forma como tem sido abordada dentro da universidade e dos órgãos educacionais com os quais dialoga.

\footnotetext{
${ }^{37}$ Entrevista concedida pelo prof. Adilson Citelli em 12.01.2012, em São Paulo/SP.
} 
Pretende-se, assim, analisar:

- Como a publicação, com base em seu modelo editorial, efetiva sua contribuição para a consolidação desta área de interface, com base nos temas propostos, conteúdos e abordagens;

- Como se dá o desenvolvimento editorial da revista, relacionado à conseqüente contribuição aos campos de estudo que aborda.

Como indicativos para o desenvolvimento desta análise, iremos observar de que modo, e com que ocorrência, a revista trata de temas como comunicação e mídia, educação, ciências da comunicação e políticas públicas ligadas à comunicação e educação, assim como de outras relacionadas direta ou indiretamente a esses assuntos.

Ressaltamos que o próprio objeto de estudo se constitui, a um só tempo, um veículo de informação e também de crítica acerca da relação entre comunicação e educação, discutindo seus efeitos enquanto influencia e é influenciado por seu desenvolvimento. Dessa forma, também é, ele próprio, veículo de análise pelo qual pesquisadores de diversas vertentes se detém sobre um objeto de estudo maior - ou seja, a interface entre a comunicação e a educação. Esta característica do próprio objeto contribui para enriquecer a pesquisa e lançar novos desafios ao seu percurso. 


\section{REFERÊNCIAS TEÓRICAS DA PESQUISA}

\section{1. História, cotidiano e identidade}

Para contextualizar o panorama social e histórico que nos trouxe até as presentes questões, e dentro do qual desenvolvem os temas tratados pela revista e a própria publicação, faremos uma breve reflexão acerca do desenvolvimento da comunicação e de sua importância na construção dos diversos papéis sociais.

O avanço das tecnologias de informação - processo histórico constante que tem sido sentido, de forma mais aguda e por maior parte da população mundial, no último século - se configura a partir de uma complexa rede de relações humanas, indo além das mudanças de caráter técnico e afetando todos os aspectos de nossa cultura. $\mathrm{O}$ alcance mundial dos meios de comunicação contribui para reforçar a sensação de que vivemos, contemporaneamente, em uma cultura também global, subseqüente à cultura de massa consolidada em meados do século XX. Os fragmentos culturais, elementos identificadores de cada grupo humano, entram em contato e se interligam, tornando-se, ao mesmo tempo, fatores de desagregação e também de condução a uma nova cultura híbrida. ${ }^{38}$ Nas palavras de Hall:

O sujeito, previamente vivido como tendo uma identidade unificada e estável, está se tornando fragmentado; composto não só de uma única, mas de várias identidades, algumas vezes contraditórias ou nãoresolvidas. Correspondentemente, as identidades, que compunham as paisagens sociais "lá fora" e que asseguravam nossa conformidade subjetiva com as "necessidades" objetivas da cultura, estão entrando em colapso, como resultado de mudanças estruturais e institucionais. ${ }^{39}$

Concorrendo com as tradições familiares, a organização social, as orientações políticas e as particularidades regionais que formam identidades pessoais, está a influência cada vez mais forte dos meios de comunicação, que, ultrapassando a esfera

\footnotetext{
${ }^{38}$ MARTIN-BARBERO, Jesús. Dos Meios às Mediações. Rio de Janeiro: UFRJ, 1997.

${ }^{39}$ HALL, Stuart. A identidade cultural na pós-modernidade. Rio de Janeiro: DP\&A, 2001, p. 12.
} 
pública, dialogam diretamente com a constituição social do receptor. De acordo com Baccega, instituições e pessoas selecionam o que vamos ouvir, ver ou ler; fazem a montagem do mundo que conhecemos. ${ }^{40}$

Aos poucos, o amplo e complexo sistema comunicacional em que estamos imersos - publicidade, jornais, televisão, meios digitais - vai reforçando e legitimando os elementos constituintes do cotidiano comum. Os símbolos econômicos, políticos e sociais, naturalizados pelas mensagens midiáticas, passam a ser confundidos com a própria essência da vida cotidiana, não passíveis de questionamentos ou avaliações mais profundas - e passando também a constituir, mediante comportamentos e atitudes, a própria identidade social de cada indivíduo - em uma estranha dialética na qual, ao buscar expressar ou construir sua consciência individual, ele exprime, na verdade, um conjunto de códigos, condutas, vocabulários e ações característicos do contexto social em que se desenvolveu.

Na vida cotidiana, o indivíduo se reproduz diretamente enquanto indivíduo e reproduz indiretamente o complexo social. (...) Este ser genérico, co-participante do coletivo, da humanidade, se encontra em potência, nem sempre realizável. Na vida cotidiana só se percebe o singular. $^{41}$

Sutilmente, a construção cotidiana de identidades vai também construindo a própria história: como define Agnes $\mathrm{Heller}^{42}$, “a vida cotidiana não está 'fora' da história, mas no 'centro' do acontecer histórico - é a verdadeira essência da substância social. Da mesma forma, e muitas vezes a despeito das intenções individuais, os efeitos produzidos pela cotidianidade conferirão sentido e sentidos à vida humana, forjando indivíduos tanto no seu "ser particular" quanto no seu "ser genérico".

Analisando aquilo que faz o dia-a-dia dos cidadãos, chegamos ao discurso do próprio tempo, sempre em mutação e renovação, trazendo os questionamentos próprios de cada momento histórico. Nas palavras de Certeau:

\footnotetext{
${ }^{40}$ BACCEGA, Maria Aparecida. Do mundo editado à construção do mundo. Comunicação \& Educação, ano 1, n.1. São Paulo, ECA/USP, 1994. p. 7.

${ }^{41}$ FALCÃO, Maria do Carmo. Cotidiano: conhecimento e crítica. São Paulo: Cortez, 1989. p. 25.

${ }^{42}$ HELLER, Agnes. O cotidiano e a história. São Paulo: Paz e Terra, 2000. p. 20.
} 
Cada tempo 'novo' dá lugar a um discurso que considera 'morto' aquilo que o precedeu, recebendo um 'passado' já marcado pelas rupturas anteriores. $^{43}$

Desta forma, pode-se relacionar a noção de cotidiano com a matéria-prima para a própria construção dos registros históricos. Ele ultrapassa, assim, a condição de "pano de fundo" para os acontecimentos mais contundentes - tradicionalmente dignos de maior registro e estudo pela historiografia - assumindo o status estruturador e reafirmador da própria história social e cultural, gerando os eventos que culminarão nos fatos históricos marcantes. E, se o cotidiano pode ser considerado usina de processos que desencadearão momentos de virada histórica, podemos considerar também os meios de comunicação como os veículos que, por natureza, se encarregam não apenas de noticiar esses processos, como de moldá-los e registrá-los para que sejam lembrados de acordo com uma interpretação específica. Nesse sentido, a comunicação deve ser vista, também, como um sistema de mediação de ideologias, estruturada para viabilizar as atividades produtivas ${ }^{44}$ e a organização social vigente - ou aquela que se pretende alcançar. Da mesma forma, os controladores dos meios de produção seriam também os controladores dos canais de comunicação, sujeitando a audiência a processos comunicacionais padronizados.

Esse sistema, no entanto, não deve ser considerado fechado a ponto de eliminarem-se as possibilidades de mudança por meio dos próprios meios comunicativos - como mostra Lopes ${ }^{45}$ ao discutir alguns princípios da abordagem gramsciana de análise da comunicação. De acordo com essa perspectiva, existem características específicas que regem a absorção da mensagem pelas diferentes classes sociais, não podendo a comunicação ser considerada, em si mesma, um processo isento de transformação social - o que dependeria do uso que as diferentes classes fariam da mensagem.

Se o cotidiano é fator determinante na construção e amadurecimento dos processos históricos, podemos concluir que, embora cadenciado por costumes, hábitos e

\footnotetext{
${ }^{43}$ CERTEAU, Michel de. A Escrita da História. São Paulo: Forense, 2006. p. 15.

${ }^{44}$ LOPES, Maria Immacolata Vassalo. Pesquisa em Comunicação. São Paulo: Loyola, 2003.

${ }^{45}$ Idem. p. 67.
} 
rotinas muitas vezes tidos como aprisionantes, este mesmo cotidiano traz em si, também, as oportunidades de mudança da história.

Toda a reprodução que ultrapassa o imediato na vida cotidiana deixa de ser cotidiana. (...) Esta passagem ocorre, como diz Agnes Heller, quando se rompe com a cotidianidade; quando um projeto, uma obra ou um ideal convoca a inteireza de nossas forças e então suprime a heterogeneidade. ${ }^{46}$

Apesar da resistência natural ao surgimento de novas tendências sociais, observa-se que a chave para os grandes acontecimentos históricos - geralmente protagonizados por um pequeno grupo de indivíduos que "catalisa" os processos e necessidades de mudança de sua época - reside ainda nas relações humanas que se constroem cotidianamente. Podemos concluir que as experiências vividas no cotidiano têm papel determinante na formação da consciência de cidadania e da inserção individual dentro do espaço coletivo. O processo revolucionário, ou antes, libertador da rotina, torna-se acessível por meio de atividades que privilegiem a expressão individual e a afirmação do papel tanto social quanto pessoal - por exemplo, através da mobilização em grupos de luta, da apropriação dos canais de expressão, do fortalecimento das redes sociais e, igualmente importante, da mudança do ponto de vista individual com relação ao próprio papel social e capacidade de mudança.

Os meios de comunicação, por exemplo, veiculam estilos de vida como a forma de viver. Entretanto, cada indivíduo deve ter a sua forma de viver. (...) Essa revolução interna é traço essencial para a existência da cidadania. Todavia, sua construção depende também de outras dimensões. É preciso haver uma educação para a cidadania. (...) É preciso criar espaços para reivindicar os direitos, mas é preciso também estender o conhecimento a todos, para que saibam da possibilidade de reivindicar. ${ }^{47}$

\footnotetext{
${ }^{46}$ FALCÃO, Maria do Carmo. Cotidiano: conhecimento e crítica. São Paulo: Cortez, 1989. p. 25.

${ }^{47}$ COVRE, Maria de Lourdes Manzini. O que é cidadania. São Paulo: Brasiliense, 2006. pp. 65-66.
} 
Desta forma, concluímos que a revolução social e coletiva passa, antes, pela revolução e conscientização individuais. O espaço a conquistar por meio da afirmação da cidadania, porém, é reforçado de forma fundamental pelas condições propiciadas por uma educação conscientizadora, que possibilite ao sujeito ser o agente de um processo contínuo - modificado, ampliado e aprimorado pela participação coletiva.

Informação não é conhecimento. O conhecimento implica crítica. Ele se baseia na inter-relação e não na fragmentação. (...) O conhecimento é um processo que prevê a condição de reelaborar o que vem como um “dado”, possibilitando que não sejamos meros reprodutores; inclui a capacidade de elaborações novas, permitindo reconhecer, trazer à superfície o que ainda é virtual, o que, na sociedade, está ainda mal desenhado, com contornos borrados. Para tanto, o conhecimento prevê a construção de uma visão que totalize os fatos, inter-relacionando todas as esferas da sociedade, percebendo que o que está acontecendo em cada uma delas é resultado da dinâmica que faz com que todas interajam, dentro das possibilidades daquela formação social, naquele momento histórico; permite perceber, enfim, que os diversos fenômenos da vida social estabelecem suas relações tendo como referência a sociedade como um todo. ${ }^{48}$

\section{2. Novas maneiras de comunicar}

Como anteriormente citado, também o jornalismo e os meios de comunicação em geral se vincularam à vida cotidiana por meio da periodicidade e da ênfase na atualidade das notícias. Ao tornar sistemática a produção e transmissão de informações, estabeleceu-se a difusão informacional como uma atividade subordinada não somente à rotina de produção industrial, mas também integrada ao capitalismo. Por fim, no atual momento de grande trânsito e confluência de informações, o ideal de visibilidade facilmente deriva para a superexposição, substituindo a "cegueira das trevas" pela "cegueira do excesso de luzes". 49

\footnotetext{
${ }^{48}$ BACCEGA, Maria Aparecida. Conhecimento, informação e tecnologia. Comunicação \& Educação, ano 5, n. 11. São Paulo, ECA/USP, 1998. p. 8.

${ }^{49}$ MORETZOHN, Sylvia. Pensando contra os fatos. Jornalismo e cotidiano: do senso comum ao
} 
Com o advento dos meios de comunicação interativos - tendo como maior representante a internet -, por sua vez, o emissor torna-se, ao mesmo tempo, também interpretante e gerador da mensagem. ${ }^{50}$ Por si só, a rede mundial de computadores permite não só o acesso seletivo a infinitos canais de informação, como apresenta, em sua própria linguagem, uma flexibilidade inédita em outras mídias. Essa possibilidade favorece o acesso não-linear e a maior inter-relação entre temas, cujo contato propicia, ainda, a relativização de conceitos específicos e o enriquecimento interpolitransdisciplinar da informação. ${ }^{51}$ Tal possibilidade passou a influenciar o modo de expressão e de identidade de toda a sociedade. Nas palavras de Costa:

Emerge na década de 1970 uma sociedade automatizada, integrada e globalizada, cujas relações se estabelecem sob a forma de redes descentralizadas, multidirecionais e integradas por polos que constituem posições individuais. Esse sistema em rede assume os mais diversos desenhos em diferentes níveis da sociedade - dentro das empresas, no comércio local e internacional, no mercado financeiro, nas articulações políticas e nas comunicações. A Internet é o mais amplo e conhecido exemplo dessas redes. ${ }^{52}$

No novo sistema de trabalho e difusão de informações, a comunicação, portanto, tem sua função radicalmente revista. Mais do que um instrumento de apoio ao processo produtivo ou formador de cultura, passa a ser, ela própria, elemento integrador e criador desses processos. Os atuais canais de comunicação, ao mesmo tempo em que abrem caminho para manifestações comunicacionais cada vez mais individualizadas, são também capazes de atrair, para um mesmo conteúdo, perfis muito diferentes de audiência, porém igualmente exigentes em suas expectativas. Como assinada Citelli:

Ao movimentar o mundo das palavras, os veículos de comunicação fazem mais do que lançar mão de um mediador técnico capaz de apresentar pensamentos ou embelezar idéias. Trata-se, antes de tudo, de criar alternativas e escolhas facultadas por este ou aquele termo, esta ou

\footnotetext{
senso crítico. Rio de Janeiro: Revan, 2007. p. 29.

${ }^{50}$ SFEZ, Lucien. A comunicação. São Paulo: Martins Fontes, 2007.

${ }^{51}$ MORIN, Edgar. A cabeça bem-feita. Rio de Janeiro: Bertrand Brasil, 2000.

${ }^{52}$ COSTA, Maria Cristina Castilho. Ficção, Comunicação e Mídias. São Paulo: SENAC, 2000. p. 78.
} 
aquela maneira de elaborar o enunciado, e, por decorrência, a informação, o conhecimento, em casos-limite, o saber. (...) A linguagem verbal é ao mesmo tempo constituinte dos sujeitos, mediadora das relações entre seres humanos e deles com a sociedade, registro da presença de tensões ideológicas, arena onde são travadas as lutas envolvendo desde diferentes interesses de grupos e classes, chegando às formas de mando e construção do poder. ${ }^{53}$

Concluímos, assim, que os novos canais de comunicação, ao pretensamente "dar voz a todos", também traduzem em si o conceito de "pulverização" característico do sistema capitalista contemporâneo, diluindo manifestações-símbolo dos diversos processos sociais e econômicos, bem ao gosto da era da "acumulação flexível" - que Castells $^{54}$ relaciona, também, com um novo paradigma de predomínio da informação sobre a energia como força impulsionadora.

Dentro desse modelo, torna-se cada vez mais complexo o desafio de cumprir, a imediaticidade dos fatos e, ao mesmo tempo, conservar o distanciamento necessário a uma análise crítica. Faz-se necessário, então, um "cotidiano exercício de suspensão" para que se possa aproximar deste ideal, tal como descrito por Georg Lukács - e citado por Moretzohn ${ }^{55}$ - a respeito do trabalho de reflexão que, ao retornar ao cotidiano, pode transformar o pensamento, intensificando o senso crítico. E, assim como não é neutra a produção dos meios de comunicação, também os receptores de suas mensagens são igualmente complexos e multifacetados. Dessa forma, somente a discussão e reflexão a respeito dos conteúdos possibilitarão o desenvolvimento da crítica aos meios de comunicação e a compreensão de sua influência na sociedade, assim como a capacidade de utilização dos recursos comunicacionais da maneira mais eficaz e construtiva possível.

Esses processos contemporâneos impactam de forma direta a maneira como a comunicação é vivenciada também no ambiente educacional. Segundo Citelli:

\footnotetext{
${ }^{53}$ CITELLI, Adilson. Palavras, meios de comunicação e educação. São Paulo: Cortez, 2006. p. 41.

${ }^{54}$ CASTELLS, Manuel. A sociedade em rede. São Paulo: Paz e Terra, 1999.

${ }^{55}$ MORETZOHN, Sylvia. Pensando contra os fatos. Jornalismo e cotidiano: do senso comum ao senso crítico. Rio de Janeiro: Revan, 2007. p. 32
} 
O movimento geral de ressignificação da escola, que deverá incluir, necessariamente, o diálogo com os 'concorrentes' mediáticos e as novas tecnologias - sempre considerando o problema na perspectiva das ampliações culturais - enfrenta, contudo, alguns óbices que poderiam ser agrupados em torno de dois grandes núcleos articulados: um conceitual e outro operacional. ${ }^{56}$

Sob esse ponto de vista, e considerando que a aprendizagem é, acima de tudo, um processo social, a educação deve privilegiar, além das informações transmitidas pelo educador, também a contribuição do próprio educando, compreendida de acordo com seu próprio referencial. Da mesma forma, deve-se levar em conta a comunicação do grupo entre si e suas contribuições para a formação de cada um individualmente. É desejável a integração contextualizada e local dos meios e recursos de informação e aprendizagem para que seja potencializada a mensagem educativa, de acordo com as necessidades e características culturais dos grupos trabalhados. Assim, estará se considerando a comunicação não como mero instrumento, mas como autêntico componente educacional - contribuindo para que se fortaleça um novo campo do saber, marcado pela utilização dos meios como prática de expressão e afirmação da cidadania.

Já não se trata mais de discutir se devemos ou não usar os meios no processo educacional ou de procurar estratégias de educação para os meios; mas sim de constatar que eles são os educadores primeiros, pelos quais passa a construção da cidadania. É desse lugar que devemos nos relacionar com eles, esclarecendo qual cidadania nos interessa. (...) Por essas e incontáveis outras razões, podemos perceber como fundamental a construção do campo comunicação/educação. Ele inclui, mas não se resume a, educação para os meios, leitura crítica dos meios, uso da tecnologia em sala de aula, formação do professor para o trato com os meios etc. etc. Ele se rege, sobretudo, pela construção da cidadania, pela inserção neste mundo editado, com o qual todos convivemos, no qual todos vivemos e que queremos modificar. ${ }^{57}$

\footnotetext{
${ }^{56}$ CITELLI, Adilson. Outras linguagens na Escola. São Paulo: Cortez, 2000. p. 23

${ }^{57}$ BACCEGA, Maria Aparecida. Da comunicação à comunicação/educação. Comunicação \& Educação, 21, ano VIII, p. 10-11
} 


\section{3. Educomunicação: espaço de interface}

Embora sejam inúmeras as discussões, ainda, a respeito do conceito e da aplicação das práticas comunicativas em ambiente educacional - em relação ao campo de trabalho ao qual pertencem, às suas formas de aplicabilidade ou a suas bases teóricas - a necessidade e a presença dos instrumentos comunicativos nesse ambiente já é consenso entre profissionais de ambas as áreas. Partindo de iniciativas, a princípio, isoladas de educadores especialmente ligados ao ensino da língua mãe, ou passando por projetos de organizações comunitárias na busca da afirmação da identidade e da expressão de crianças e jovens, a aproximação entre ensino e mídia foi se fortalecendo ao longo dos anos em todo o mundo, e também na América Latina e no Brasil, até se tornar mais do que uma estratégia de integração entre professores, alunos e ambiente - e espelhando, de fato, a intensificação de um processo histórico e social que tem marcado a humanidade durante a última metade de década.

A chamada geração de "nativos digitais", jovens que já nasceram "plugados" e desenvolveram a capacidade de interação e de múltipla atenção aos canais comunicacionais desde a infância, exige dos educadores uma abordagem totalmente nova e revista dos conhecimentos que eles próprios apreenderam por modelos diversos. Esse fenômeno torna ainda mais necessária e presente a interação entre mídia e educação, algo já exercido de maneira desafiadora e instigante desde o início do século XX. Registros históricos como os do pedagogo francês Célestin Freinet, do médico e educador polonês Janusz Korczak e do educador brasileiro Paulo Freire nos dão conta de abordagens inovadoras para se pensar e exercer a educação, por meio da revisão de discursos, instrumentos e, principalmente, da ampliação do papel do educando no processo de aprendizagem. Cada uma a seu modo, as diversas experiências ao longo do tempo têm ajudado a consolidar um uma nova interface de trabalho e estudo, que deu origem ao conceito de Educomunicação - ou, por sua forma abreviada, Educom. Conforme a definição de Soares:

O neologismo "Educomunicação" ainda não se encontra dicionarizado, apesar de seu uso na Europa já nos anos de 1980, para designar projetos apoiados pela UNESCO voltados à educação para a recepção 
crítica das mensagens midiáticas. No Brasil, o termo foi ressemantizado pelo Núcleo de Comunicação e Educação (NCE) da USP, que o adotou, no final dos anos 90, para designar uma área de prática social mais complexa, caracterizada, em termos operacionais, pela gestão compartilhada da comunicação em espaços educativos, estando sustentada, em termos teóricos, pelo reconhecimento do direito à expressão e ao acesso aos recursos da produção midiática. ${ }^{58}$

Mais do que mero instrumental, portanto, podemos considerar a Educomunicação como um novo paradigma no trabalho entre os dois campos. A ausência de unanimidade no uso do termo, dentro da academia ou das demais instituições, não impede a atenção crescente de teóricos e profissionais que se dedicam a estudar seus efeitos e aplicar suas potencialidades - ainda que sob nomes diversos, que traduzem sua totalidade ou alguma de suas especificidades, como Media Education ou Media Literacy. Se o campo da educação, ao se deter ao trabalho ligado à comunicação, normalmente foca sua atenção à análise crítica das mensagens - enquanto a comunicação busca conduzir a formação de hábitos e valores do público por meio, por exemplo, do entretenimento e da publicidade - podemos analisar esta relação de acordo com Soares:

A Educomunicação, ao reconhecer e codividir tais preocupações, situase a partir de seu lugar específico, que é a interface. Reconhece, em primeiro lugar, o direito universal à expressão, tanto da mídia quanto de seu público. (...) Em decorrência, fará todo o esforço necessário para ampliar o potencial comunicativo dos membros da comunidade educativa e - no contexto de seu espaço privilegiado, que é a escola de todos os membros desta comunidade, sejam docentes ou discentes, ou, ainda, a comunidade do entorno. ${ }^{59}$

\footnotetext{
${ }^{58}$ SOARES, Ismar de Oliveira. Educomunicação: o conceito, o profissional, a aplicação. São Paulo: Paulinas, 2011.

${ }^{59}$ Idem, p. 18.
} 


\section{Educomunicação e linguagem: revendo os processos educacionais}

De acordo com Paulo Freire, mais do que simplesmente absorver conhecimento, é necessário que o estudante descubra, de acordo com seus próprios referenciais, a melhor maneira de aprender o que lhe é transmitido. Nesse sentido, a educação, mais do que canal unilateral de transmissão de informações, é um elemento de construção e reconhecimento da própria identidade cultural e social.

A educação é comunicação, é diálogo, na medida em que não é transferência de saber, mas um encontro de sujeitos interlocutores que buscam a significação do significado. ${ }^{60}$

Assim como não é neutra a produção dos meios de comunicação, também os receptores de suas mensagens - incluindo-se aí os alunos - são igualmente complexos e multifacetados. Dessa forma, a discussão a respeito dos conteúdos tem papel fundamental no desenvolvimento da crítica aos meios de comunicação e na compreensão de sua influência na sociedade, assim como na capacidade de se utilizar os recursos comunicacionais de forma construtiva no processo educacional.

Citelli chama a atenção para o fato de que "o desafio proposto à educação formal para o trabalho envolvendo o fluxo das palavras pelos veículos de comunicação requisita mais do que a nomeação de fenômenos gramaticais ensejados nos discursos, visto solicitar, também, o desenvolvimento de estratégias compreensivas e de apreensão dos matizes, variáveis, instâncias de uso e, sobretudo, dos valores, que construirão os campos de sentidos dos signos verbais em circulação pelos media." 61

A transição entre a educação tradicional, baseada na transmissão unilateral e essencialmente verbal de conhecimentos, e a vivência inevitável de questões sociais e comunicacionais multifacetadas, traz em si outro desafio: a divisão entre a visão humanista e a visão que privilegia o instrumental no uso das novas tecnologias.

\footnotetext{
${ }^{60}$ FREIRE, Paulo. A importância do ato de ler. São Paulo: Cortez, 1982.

${ }^{61}$ CITELLI, Adilson. Palavras, meios de comunicação e educação. São Paulo: Cortez, 2006. p. 166.
} 
Ainda incipiente em muitas ações, por vezes a comunicação educativa limita suas atividades ao manuseio dos canais midiáticos, ligando seu próprio significado, quase que automaticamente, à operação dos meios e tecnologias de transmissão da comunicação. ${ }^{62}$ Torna-se necessário, dessa forma, que as atividades privilegiem não só as habilidades técnicas de operação das mídias, mas também seu potencial como verdadeiras geradoras de informação em novos formatos, capazes de se aproximar da linguagem já naturalmente utilizada pelos educandos - ampliando-a e instaurando novas formas de aprendizado e intercâmbio de conhecimentos.

Tedesco $^{63}$ reforça esta ideia quando considera, como verdadeiro salto nos processos educacionais, o uso das novas tecnologias ao lado da educação assistida, ou seja, da interação comunicativa entre alunos e professores - ao contrário do modelo hierarquizado de educação formal, dentro do qual é dificultada a intervenção do aluno. Ou, nas palavras de Baccega:

\begin{abstract}
É preciso produzir reflexão sobre o campo Comunicação e Educação. $O$ campo não se restringe às atividades comunicacionais nas escolas, ou seja, a fazer um jornal. É muito além disso. O jornal pode ser um resultado desse muito além, que é algo que está faltando. É preciso pensar o que é o campo, que tipo de proposta teórica temos para ele. Deve haver uma contextualização teórica do fazer, senão ficaremos reproduzindo aquilo que já está - e esse é o grande medo: endeusar ainda mais os meios do jeito que estão. Não temos que esquecer a televisão; pelo contrário, temos que ver televisão, discutir, pensar - mas temos que ter propostas para mudar. ${ }^{64}$
\end{abstract}

Para alcançar esse resultado, porém, a escola tem desafios de diversas ordens a enfrentar, incluindo o posicionamento do próprio corpo docente. A partir de uma pesquisa sobre a circulação de textos realizada em quatorze escolas do Estado de São

\footnotetext{
${ }^{62}$ KAPLÚN, Mario. Processos educativos e canais de comunicação. Comunicação \& Educação, ano 5, n. 14. São Paulo, ECA/USP, 1999.

${ }^{63}$ TEDESCO, Juan Carlos. Educação e Novas Tecnologias. Esperanças ou incertezas? São Paulo, Cortez, 2004.

${ }^{64}$ Entrevista concedida pela professora Maria Aparecida Baccega em 27.04.2012, em São Paulo/SP.
} 
Paulo, o livro Ensinar e aprender com textos não escolares ${ }^{65}$ discute o distanciamento da instituição escolar das linguagens dos veículos de massa. Entre os resultados do estudo, está a constatação do descompasso entre o discurso didático-pedagógico e as linguagens marcadas pelos media, repletas de símbolos não necessariamente verbais e que, não obstante constituam parte ativa do cotidiano dos alunos, estão, em sua maioria, ausentes da programação escolar formal.

A obra discute, ainda, as dificuldades operacionais no uso das linguagens digitais pelos professores, cuja familiaridade com estes meios não fez parte de sua formação profissional e de sua vivência pessoal de base. Da mesma forma, não se pode pressupor que dominem ou operem a totalidade das linguagens não-institucionais - mas sim que, ao longo do tempo, possam desenvolver a capacidade de analisá-las criticamente, decodificá-las e perceber seu potencial, utilizando-as tanto como auxiliares no processo educativo quanto como fonte para o desenvolvimento, nos alunos, dos mecanismos de leitura crítica das informações, a partir de seus próprios referenciais. Também nas palavras de Orozco:

Se o que nossos alunos aprendem fora da aula é relevante para sua aprendizagem dentro da escola, é obrigação nossa, como educadores, tomar em conta essa aprendizagem. (...) São os professores que enfrentam diariamente seus alunos de primário e secundário, aqueles que estão sendo testemunhas das condições e dos limites da situação cultural, econômica e política na qual se tem que cumprir a função de ensinar. ${ }^{66}$

Sendo instância que impregna o tecido social e é por ele impregnada, de acordo com Citelli, ${ }^{67}$ a educação resgata, ou deveria resgatar em sala de aula, os processos sociais já latentes. Desta forma, a reflexão acerca da aproximação entre a escola e as mensagens e vivências inspiradas pela mídia deve passar também pela atualização das relações entre os sujeitos e agentes - neste caso, professores e alunos que desenvolvam a consciência das muitas mediações que os circundam neste mundo contemporâneo. A

\footnotetext{
${ }^{65}$ CITELLI, Adilson. Ensinar e aprender com textos não escolares. São Paulo: Cortez, 2003.

66 GÓMEZ, Guilhermo Orozco. Professores e meios de comunicação: desafios e estereótipos. Comunicação \& Educação, ano 3, n. 10. São Paulo, ECA/USP, 1997. p. 63.

${ }^{67}$ CITELLI, Adilson. Outras linguagens na Escola. São Paulo: Cortez, 2000.
} 
escola exerceria, assim, o papel fundamental de se transformar em espaço mediativo que, mais do que utilizar os mecanismos comunicacionais como auxiliares tecnológicos, possibilitaria o diálogo crítico entre professores, estudantes e os próprios veículos de comunicação. ${ }^{68}$

\section{Educomunicação e "Ecossistema Comunicativo"}

Mário Kaplún, no texto Processos Educativos e Canais de Comunicação, vê, como uma das missões da comunicação educativa, a capacidade de prover meios para o desenvolvimento da competência comunicativa dos educandos por meio de vias horizontais de intercomunicação. ${ }^{69}$ Utilizando o conhecimento e cultura dos alunos como ponto de partida, a educação pode tanto trabalhar sobre os modelos massificados de transmissão de informações adotados pela mídia, discutindo de forma crítica a elaboração de mensagens por esses modelos, como utilizar o potencial informativo dos meios para instaurar novas formas de aprendizado e intercâmbio de conhecimentos.

Orozco, ${ }^{70}$ por sua vez, afirma que os educadores se apresentam atualmente diante de seis grandes ordens de desafios: informático, formal, técnico, preferencial, de efetividade pedagógica e de relevância educativa. Compete-lhes utilizar sua formação pedagógica para traçar novos âmbitos de trabalho, tendo os meios de comunicação como vias para a construção e reflexão do conhecimento em sala de aula, ao mesmo tempo em que utilizam esses meios como co-formadores de identidade social.

Dentro da área de interface da Educomunicação, Ismar de Oliveira Soares ${ }^{71}$ enumera algumas áreas específicas de atuação. Seriam elas:

a) A área da educação para a comunicação, configurada nos esforços de educadores em colaborar com os usuários dos meios massivos na formação de uma "consciência crítica" frente às mensagens veiculadas pelos sistemas de comunicação;

\footnotetext{
${ }^{68}$ CITELLI, Adilson. Ensinar e aprender com textos não escolares. São Paulo: Cortez, 2003.

${ }^{69}$ KAPLÚN, Mario. Processos educativos e canais de comunicação. Comunicação \& Educação, ano 5, n. 14. São Paulo, ECA/USP, 1999. p. 68-75.

${ }^{70}$ GÓMEZ, Guilhermo Orozco. Professores e meios de comunicação: desafios e estereótipos. Comunicação \& Educação, ano 3, n. 10. São Paulo, ECA/USP, 1997.

${ }^{71}$ SOARES, Ismar de Oliveira. EAD como prática educomunicativa. Revista USP, n. 55. São Paulo, USP, 2002. p. 56.
} 
b) A área de expressão comunicativa por meio das artes, representada pelos esforços de arte-educadores no sentido de garantir espaços de expressão e visibilidade para os diversos sujeitos sociais;

c) A área da mediação tecnológica nos espaços educativos, ou seja, os esforços de identificação de origens da interatividade propiciada pelos novos instrumentos da comunicação. Contempla ainda os esforços de democratização do acesso às tecnologias;

d) A área da gestão da comunicação nos espaços educativos, caracterizada pela abordagem sistêmica das relações entre os recursos da comunicação e as atividades humanas, garantindo a eficácia dos sistemas comunicativos.

As práticas citadas acima contribuem para o estabelecimento do chamado “ecossistema comunicativo", conceito utilizado em sentido próximo por autores como Mário Kaplún, Jesús Martin-Barbero, Pierre Lévy, Adilson Citelli e Ismar de Oliveira Soares. ${ }^{72}$ Nas palavras de Soares, mais do que educar usando o instrumento da comunicação, trata-se de converter a própria comunicação em fio condutor dos processos educativos, transformando a educação comunicativa em uma relação e não em um objeto, a partir de um projeto pedagógico ampliado. ${ }^{73}$

Como reafirma Citelli, a questão central "não é a de estreitar vínculos entre dinâmicas comunicativo-tecnológicas e as salas de aula, mas fazê-lo sob uma égide não instrumental - aquela que ao se encantar com as máquinas perde a dimensão dos significados sociais, culturais, históricos, nelas embutidos. (...) O lugar das tecnologias na escola - e mesmo para o chamado ensino a distância - deve ser aquele voltado aos interesses de uma educação anteriormente definida como emancipadora, capaz de facultar autonomia de pesquisa e, sobretudo, reconhecimento do sujeito no mundo." 74

\footnotetext{
${ }^{72}$ CITELLI, Adilson. Comunicação e educação: convergências educomunicativas. Comunicação, Mídia e Consumo, vol. 7, n. 19. São Paulo, ESPM, 2010.

${ }^{73}$ SOARES, Ismar de Oliveira. Educomunicação: um campo de mediações. Comunicação \& Educação, ano 7, n. 19. São Paulo, ECA/USP, 2002.

${ }^{74}$ CITELLI, Adilson. Comunicação e educação: convergências educomunicativas. Comunicação, Mídia

e Consumo, vol. 7, n. 19. São Paulo, ESPM, 2010. p. 80
} 


\section{Educom como política pública}

O fortalecimento das iniciativas envolvendo comunicação e mídias no Brasil, durante a última década, ajudou a abrir caminhos para um passo fundamental no reconhecimento de sua importância: o surgimento de políticas públicas que levam em conta sua presença como uma das bases do processo de aprendizado, além de instrumento de conscientização acerta dos chamados "temas transversais" (ética; saúde; meio ambiente; orientação sexual; pluralidade cultural; trabalho e consumo) - cuja proposta de introdução formal no currículo escolar brasileiro data de 1998 e que têm sido trabalhados, no campo da educação não formal, por inúmeras organizações nãogovernamentais.

Pode-se dizer que o próprio fortalecimento das iniciativas envolvendo a comunicação e educação, no Brasil, seguiu o princípio Freireano de pedagogia, que confronta e revê hierarquias estabelecidas: tendo florescido inicialmente fora do mundo escolar, esta interface se aproximou das organizações do Terceiro Setor, da mídia especialmente por meio das TVs e rádios educativas - e, finalmente, da escola. O mesmo princípio se aplica, de modo geral, às iniciativas neste campo em outros países latinos, como explica Soares:

Diferentemente do que ocorreu em outros continentes, o maior volume da prática deu-se, na América Latina, no contexto do movimento denominado "educação popular", comunicação alternativa", “comunicação popular e alternativa” com a adoção de uma perspectiva dialética. No caso, o que as ações e cursos das entidades envolvidas com o tema pretendiam discutir não era exatamente o impacto das mensagens sobre suas audiências, mas a relação que os receptores estabeleciam com os meios de comunicação, ou, em outras palavras, o modo como as audiências reagiam e se articulavam ao receber e ressignificar os conteúdos midiáticos. ${ }^{75}$

A primeira iniciativa de se incluir a Educomunicação em uma política pública

\footnotetext{
${ }^{75}$ SOARES, Ismar de Oliveira. Educomunicação: o conceito, o profissional, a aplicação. São Paulo: Paulinas, 2011. p. 34.
} 
deu-se por meio da Lei de Diretrizes e Bases da Educação (LDB), de 1996, que sugeriu a comunicação como aliada nos processos educacionais - introduzindo a ideia de que a educação não se limita à escola e a seus meios formais de ensino, mas constitui-se num campo amplo envolvendo família, relações sociais, trabalho, sociedade e cultura, além dos meios de comunicação inseridos nesse ambiente. ${ }^{76}$

Em 2005, também o Ministério do Meio Ambiente, por meio de sua área de Educação Ambiental, utilizou a Educom na implementação das Conferências InfantoJuvenis de Meio Ambiente, em parceria com o Ministério da Educação. A experiência trouxe subsídios para a formalização do uso de recursos educomunicativos no Programa Nacional de Educação Ambiental (ProNEA), que direcionou atividades de formação em comunicação e educação ambiental a profissionais que fazem a administração das áreas de preservação brasileiras.

Todo esse movimento de interesse pela comunicação aliada à educação foi acompanhado, também, pela revista Comunicação \& Educação - que "a entende [a Educomunicação], mais propriamente, como uma das possibilidades de interpretação do universo simbólico presente na interface entre a comunicação e a educação. "77 Nas palavras de Baccega:

Acho que, na medida em que o campo comunicação e educação foi se implantando, encontramos na revista repercussões desse campo e, portanto, da própria revista, o que é um diferencial. Acho, inclusive, que essa é uma das funções mais importantes da revista. As pessoas começaram a saber que a área existe. (...) Já existem condições de diálogo, livros sobre o assunto. Começamos a ter uma certa estrutura científica para discutir o tema. E a revista foi fundamental - a cada congresso, levávamos a publicação, fazíamos palestras, discutíamos com as pessoas. Fomos bastante pioneiros, e acho que fizemos bem. ${ }^{78}$

\footnotetext{
${ }^{76}$ LIMA, Solange Martins Couceiro. Comunicação \& Educação: um olhar para a diversidade. Comunicação \& Educação, ano 12, n. 1. São Paulo, ECA/USP, 2007.

${ }^{77}$ SOARES, Ismar de Oliveira. A contribuição da revista Comunicação \& Educação para a criação da Licenciatura em Educomunicação. Comunicação \& Educação, ano 14, n. 3. São Paulo, ECA/USP, 2009.

${ }^{78}$ Entrevista concedida pela professora Maria Aparecida Baccega em 27.04.2012, em São Paulo/SP.
} 


\section{METODOLOGIA DA PESQUISA}

A estruturação de um modelo metodológico mostra-se fundamental para a realização de uma pesquisa que possa, efetivamente, acrescentar conhecimentos e contribuir para o sucesso da realização de projetos. Mais do que operacionalizar ações, é importante que os profissionais envolvidos na elaboração das pesquisas privilegiem, também, a instância metodológica em seus trabalhos, de forma a enriquecer os referenciais teóricos dessa fase de planejamento - fundamental para a boa evolução das atividades práticas da comunicação, bem como de sua inter-relação com as bases teóricas que constituem seu referencial.

Guiados por esse pensamento, e unindo os conceitos de coleta de dados em campo, análise editorial e análise de enquadramento, pretendemos analisar a contribuição da revista Comunicação \& Educação dentro do campo da comunicação educativa, bem como a trajetória dos próprios conceitos envolvidos nesta interface de estudo e de trabalho.

A análise da história da publicação pretende contribuir com a reflexão acerca do desenvolvimento da própria discussão dos conceitos de comunicação e educação no ambiente acadêmico, bem como da aplicação prática desses conhecimentos em iniciativas escolares ou comunitárias. Da mesma forma, a maneira pela qual os temas são abordados e tratados pela revista, desde seu lançamento, pode fornecer precioso material de pesquisa tanto a respeito de seu posicionamento como veículo de divulgação científica como com relação à própria escolha e repercussão, ao longo das edições, dos temas por ela tratados.

\subsection{Técnicas de observação}

Mais do que possibilitar o aumento ou aprofundamento das informações que darão base à análise do objeto, as técnicas de coleta de dados devem também conferir significado epistemológico a essa atividade, assim como contribuir com a visão teórica sobre os problemas apresentados. Enquanto "teorias em ato" - procedimentos de 
construção dos dados e das relações entre eles ${ }^{79}$ - sua concepção e execução deve ser integrada à concepção do projeto.

Ao lado dos recursos de observação direta, pesquisa bibliográfica e entrevistas em profundidade, a técnica de observação central deste trabalho consiste na análise editorial de todas as edições - material que constitui a base para o estudo das hipóteses já especificadas. Como fatores levados em conta na análise da publicação, estão os temas constituintes de cada número e sua abordagem; os conceitos teóricos debatidos; as tecnologias citadas como parte do processo envolvendo comunicação e educação; os autores constantes e seus referenciais; e as principais questões abordadas pelas diferentes edições.

Pretende-se, dessa forma, traçar um panorama do desenvolvimento da publicação e, consequentemente, o acompanhamento da evolução da própria área de interface entre comunicação e educação, a partir dos pontos-chave de discussão dos profissionais e estudiosos envolvidos com esses campos - e dos dois pressupostos básicos discutidos pela revista: o pensar a Educomunicação, provocando a reflexão crítica; e o agir, buscando formas de atuação que levem à prática os conhecimentos e técnicas discutidos.

Para o levantamento e análise desde conteúdo, e especialmente da evolução editorial da revista Comunicação \& Educação, serão utilizadas as bases de uma metodologia denominada análise de enquadramento.

\section{A análise de enquadramento}

De acordo com Stephen Reese, o enquadramento refere-se ao modo como os eventos são organizados e fazem sentido. Ele permite-nos analisar a maneira pela qual os temas são construídos, os discursos estruturados e os significados desenvolvidos. ${ }^{80} \mathrm{O}$ conceito de enquadramento (no original framing) foi abordado de forma sistemática, pela primeira vez, na obra Frame Analysis: an Essay on the Organization of

\footnotetext{
${ }^{79}$ LOPES, Maria Immacolata Vassalo. Pesquisa em Comunicação. São Paulo: Loyola, 2003.

${ }^{80}$ MESQUITA, Flávio Agnelli. O dia " $D$ ": análise do enquadramento às coberturas de Veja e IstoÉ no domingo anterior às eleições presidenciais do $2^{\circ}$ turno. Anais de Comunicação da Universidade Estadual "Júlio de Mesquita Filho" (UNESP), 2007.
} 
Experience, do sociólogo norte-americano Erving Goffman - tendo recebido contribuições de outros pesquisadores que, nos anos seguintes, desenvolveram e aplicaram o modelo a seus estudos de jornalismo. Entre eles está o pesquisador americano Robert Entman, ${ }^{81}$ responsável pela mais conhecida definição do conceito:

\begin{abstract}
Enquadrar é selecionar alguns aspectos de uma realidade percebida e fazê-los mais salientes em um texto comunicativo, de forma a promover uma definição particular do problema, uma interpretação casual, uma avaliação moral elou uma recomendação de tratamento para o item descrito.
\end{abstract}

Transportando este conceito para a veiculação de informações pela mídia de forma geral, podemos dizer que a análise de enquadramento é o estudo da maneira "pela qual a influência sobre a consciência humana é exercida pela transferência (ou comunicação) de informação de um local - como um discurso, pronunciamento, notícias, ou um livro - àquela consciência". 82

Segundo Scheufele, ${ }^{83}$ os enquadramentos noticiosos podem ser divididos em duas categorias: os media frames (enquadramentos midiáticos) e os individual frames (enquadramentos individuais). A primeira envolve as informações produzidas pela mídia e inseridas nos textos noticiosos; a segunda, por sua vez, é construída a partir das "estruturas internas da mente" do receptor.

Enquadramentos dizem às pessoas que relevância devem dar a aspectos conflituosos do cotidiano das decisões políticas. Eles podem não acrescentar nenhuma nova informação, mesmo assim, a influência em nossas opiniões pode ser decisiva. ${ }^{84}$

\footnotetext{
${ }^{81}$ ENTMAN, Robert. Framing U.S. Coverage of international news: contrasts in narratives of the KAL and Iran Air incidents [Cobertura internacional de notícias: contrastes nas narrativas do KAL e dos incidentes da Iran Air]. Journal of Communication, vol. 41, n. 4. Washington, International Communication Association, 1991.

${ }^{82}$ ENTMAN, 1993, p. 51 in RESENDE, Letícia Passos (2011). Inovação, estudos CTS e comunicação científica: a divulgação das pesquisas de materiais cerâmicos e nanotecnologia. Dissertação de Mestrado - Centro de Educação e Ciências Humanas da Universidade Federal de São Carlos. p. 51.

${ }^{83}$ Framing as a Theory of Media Effects [Enquadramento como uma teoria de efeitos de mídia]. Journal of Communication, 49. Washington, International Communication Association, 1999. p. 107.

${ }^{84}$ NELSON, OXLEY e CLAWSON, 1997, apud RESENDE, Letícia Passos. Inovação, estudos CTS e comunicação científica: a divulgação das pesquisas de materiais cerâmicos e nanotecnologia.
} 
De acordo com Entman, algumas das ferramentas para a montagem de uma análise de enquadramento são: posicionamento da informação no texto; repetição; escolha de palavras; metáforas; exemplos; descrições; argumentos; imagens ou "associação com símbolos culturais familiares" à audiência. ${ }^{85}$ Esses elementos encontrarão ainda maior receptividade e efeito quanto menor for o conhecimento prévio do receptor sobre o assunto debatido - e, por conseguinte, a quantidade de experiências e conceitos que influenciarão o processo de construção de sentido a partir da mensagem (incluindo interesses, valores, crenças, vivências e aspirações, por exemplo). Igualmente, as próprias rotinas e propósitos da produção de informações irão influenciar o enquadramento escolhido para retratar determinado conteúdo. Dessa forma, a construção de enquadramentos envolve a interação entre o nível textual (frames aplicados pela mídia); cognitivo (hábitos de pensamento do público e dos profissionais da mídia); externo à mídia (o discurso de construtores de enquadramento) e, finalmente, o repertório de conceitos (“quadros”) disponíveis numa certa cultura. ${ }^{86}$

O conceito de enquadramento, portanto, nos oferece a possibilidade de investigar, por meio da apresentação textual, aspectos amplos e altamente influenciadores da audiência, como a ideologia presente na veiculação de cada conteúdo. O enquadramento noticioso, realizado de forma consciente ou inconsciente pelo gerador da mensagem, nos diz sobre a visão do emissor a respeito do fato noticiado - começando pela própria escolha deste ou daquele tema a ser divulgado. Ele influenciará de maneira decisiva, também, a maneira pela qual a mensagem será recebida e retransmitida. A partir desse pressuposto, pode-se analisar um conteúdo específico para além dos conceitos tradicionais de "objetividade/subjetividade", de acordo com McLeod e Detenber. ${ }^{87}$

A mídia de massa, e outras instituições políticas ou de comunicação, podem influenciar profundamente a opinião pública sem mesmo tentar

Dissertação de Mestrado - Centro de Educação e Ciências Humanas da Universidade Federal de São Carlos, 2011.

${ }^{85}$ ENTMAN, 1993, p. 53 apud RESENDE, Letícia Passos. Inovação, estudos CTS e comunicação científica: a divulgação das pesquisas de materiais cerâmicos e nanotecnologia. Dissertação de Mestrado - Centro de Educação e Ciências Humanas da Universidade Federal de São Carlos, 2011.

${ }^{86}$ VAN GORP, 2007, p. 64 apud RESENDE, Letícia Passos. Inovação, estudos CTS e comunicação científica: a divulgação das pesquisas de materiais cerâmicos e nanotecnologia. Dissertação de Mestrado - Centro de Educação e Ciências Humanas da Universidade Federal de São Carlos, 2011.

${ }^{87}$ Apud LEAL, Plínio Marcos Volponi. Jornalismo Político Brasileiro e a Análise do Enquadramento Noticioso. Apresentado no II Compolítica - Congresso da Associação Brasileira dos Pesquisadores de Comunicação e Política. Belo Horizonte, 2007. 
persuadi-la ou a manipular. A mídia pode, sinceramente, seguir normas institucionais de imparcialidade e neutralidade; mesmo assim, ela não pode escapar ao fato de sua aproximação a uma história, implicitamente, ensinar o público como entender os assuntos centrais. Estes efeitos podem ser não intencionais, mas eles são, todavia, reais. ${ }^{88}$

Pelo descrito até o momento, percebemos que a análise de enquadramento pode contribuir grandemente na pesquisa sobre a trajetória da revista Comunicação \& Educação, bem como sobre a formação de sua linha editorial, as linhas que atualmente a conduzem e de sua receptividade junto ao público. Por meio da observação de como os temas são reunidos e apresentados na revista, é possível traçar as diretrizes teóricas, pedagógicas e comunicacionais com as quais a publicação se alinha, além de observar, por meio da abordagem dos temas, o posicionamento da própria revista diante dos assuntos tratados e de sua evolução - relacionando-o, inclusive, às referências teóricas já discutidas anteriormente neste trabalho. Portanto, no caso da observação do objeto de estudo desta pesquisa, a análise de enquadramento se centra sobre as diretrizes já especificadas, mais do que no viés político ou jornalístico característicos de seu emprego em outras pesquisas.

\section{2 Descrição dos dados}

De acordo com Lopes, ${ }^{89}$ a análise descritiva em uma pesquisa é feita, primeiramente, por meio de procedimentos técnicos de organização, crítica e classificação dos dados coletados. Em seguida, procede-se à construção do objeto empírico. Esta fase é composta das seguintes etapas:

\section{Organização, crítica e classificação dos dados}

A organização dos dados foi realizada por meio da análise do material reunido de forma qualitativa, levando em conta os pressupostos já enumerados (história da revista, perfil editorial, relação com discussões de profissionais e estudiosos das áreas

\footnotetext{
${ }^{88}$ NELSON, OXLEY e CLAWSON, 1997, apud RESENDE, Letícia Passos. Inovação, estudos CTS e comunicação científica: a divulgação das pesquisas de materiais cerâmicos e nanotecnologia.

Dissertação de Mestrado - Centro de Educação e Ciências Humanas da Universidade Federal de São Carlos, 2011. p. 236

${ }^{89}$ LOPES, Maria Immacolata Vassalo. Pesquisa em Comunicação. São Paulo: Loyola, 2003.
} 
envolvidas). O objetivo desta etapa foi traçar um perfil aprofundado da publicação, de seu público e da evolução de sua linha editorial, todos bastante específicos.

\section{Análise descritiva}

O método descritivo de estudo de caso complementa, qualitativamente, o perfil detalhado da revista, de sua história e dos autores participantes das edições.

\subsection{Interpretação dos dados}

A fase seguinte consiste na interpretação dos dados coletados. Envolve a teorização dos dados empíricos dentro da perspectiva teórica adotada pela pesquisa, retomando dialeticamente o ponto de partida e integrando os dados numa totalidade que é, igualmente, objeto empírico e objeto teórico. No caso da presente pesquisa, mostrouse especialmente adequada a análise de dados de acordo com a perspectiva dialética, realizada com base nos paradigmas de comparação entre o fenômeno comunicacional e os processos sociais. 


\subsection{Coleta de dados}

\subsubsection{Observação Direta}

A vivência como leitora, colaboradora da revista e, posteriormente, editora executiva da mesma, forneceu dados preciosos para a compreensão do perfil editorial da publicação e de sua repercussão junto ao público a que se destina - informações utilizadas, também, para a construção do objeto de estudo deste trabalho. A descrição dos dados, bem como sua análise, está presente na construção de toda a pesquisa e terá alguns de seus aspectos mais importantes detalhados a seguir.

\subsubsection{Pesquisa Bibliográfica}

Também o processo de legitimação do campo foi tema de pesquisa bibliográfica junto a documentos da Escola de Comunicações e Artes, que comprovassem a busca pelo desenvolvimento de ações e projetos sistematizados em comunicação e educação. Informações sobre o fortalecimento desta área dentro da ECA também serão descritos nas próximas páginas.

\subsubsection{Entrevistas em profundidade}

Foram realizadas entrevistas a respeito da história da revista com quatro dos professores que participaram ativamente de sua criação e desenvolvimento: Maria Aparecida Baccega, Adilson Citelli, Maria Cristina Castilho Costa e Ruth Ribas Itacarambi. As entrevistas realizadas especificamente para esta pesquisa, nas dependências da Escola de Comunicações e Artes da USP ou na residência da entrevistada - no caso da professora Baccega - entre os meses de janeiro e abril deste ano, forneceram informações fundamentais para a reconstituição histórica e de identidade da revista. 


\subsubsection{Análise de Enquadramento}

Por fim, o trabalho de coleta de dados se aprofundou por meio da leitura e análise de enquadramento das seções Apresentação de todos os números da revista. Esta seção foi escolhida por trazer a síntese dos artigos constantes de cada edição, além de discutir os temas mais relevantes para o período do número em questão. Dessa forma, foi possível traçar um panorama editorial da publicação através dos anos, assim como do contexto social e histórico em que foi produzido cada número.

Realizou-se, ainda, um levantamento dos temas tratados em todos os textos da revista desde seu início, tendo como base as palavras-chave e o perfil dos autores que contribuíram com cada seção.

\subsection{Descrição dos dados}

\subsubsection{Observação Direta}

Desde o ano de 2004, data do primeiro contato com a revista Comunicação \& Educação, observei a preocupação da publicação em unir a atualidade dos temas à sua aplicabilidade nos espaços educativos - expressa dentro das características de cada seção, fosse composta por artigos acadêmicos ou de caráter e conteúdo jornalísticos. A escolha das pautas para as seções Entrevista e Depoimento, de cuja elaboração participei como repórter e redatora - incluindo, como fontes, artistas das áreas de dança, dramaturgia e música; coordenadores de políticas públicas; escritores, líderes comunitários e professores, entre outros - refletiu a preocupação com a diversificação dos temas e a busca pelo olhar amplo sobre o tema da comunicação e educação. Também a seção Endereços úteis na internet, pela qual fui responsável entre os anos de 2006 e 2010, mostrou-se importante num momento de consolidação do uso da internet como fonte de pesquisa e instrumento comunicacional utilizado também por educadores.

Ao lado dessas tendências, como foi detalhado no histórico da revista - a partir de dados recolhidos inclusive por meio da observação direta - verificou-se a busca da 
publicação, também, pela legitimidade acadêmica - conquistada por meio das positivas avaliações dentro do critério QUALIS e do credenciamento nos Portais de Periódicos da USP e da CAPES, entre outras ações. Dessa forma, a publicação, ao longo de sua trajetória, passou a aliar seus propósitos educacionais ao oferecimento de conteúdo com forte embasamento teórico, de interesse nos ambientes de pesquisa. A forma como isso foi realizado será analisada mais à frente.

\subsubsection{Pesquisa bibliográfica}

Dentro da ECA/USP, a formalização do estudo da interface entre comunicação e educação se deu em 1996, por meio da criação de um Núcleo de Pesquisa reunindo as ações e atividades voltadas ao tema, com a participação de professores de diversas universidades do Brasil: o Núcleo de Comunicação e Educação - NCE. Inaugurando as atividades do Núcleo, foi realizada, entre 1997 e 1999, uma extensa pesquisa ${ }^{90}$ que teve como objeto o conceito de Educomunicação e o perfil dos profissionais envolvidos com o tema em 12 países da América Latina e da Península Ibérica. Os resultados deste trabalho permitiram ao NCE definir bases teóricas e traçar estratégias para suas ações futuras.

$$
\begin{aligned}
& \text { No caso do Núcleo de Comunicação e Educação - NCE, o que o } \\
& \text { caracteriza é a dinâmica da pesquisa-ação, o que significa produzir } \\
& \text { pesquisa para devolvê-la imediatamente à sociedade através de } \\
& \text { assessorias e projetos de intervenção social. }{ }^{91}
\end{aligned}
$$

Um exemplo de iniciativa implantada na rede formal de ensino por meio de políticas públicas é o projeto Educom.rádio (Educomunicação pelas Ondas do Rádio), organizado pelo NCE em parceria com a Secretaria Municipal de Educação de São Paulo. Desenvolvido durante a última década em escolas públicas da cidade, o projeto teve como objetivo a utilização da linguagem radiofônica na construção de ambientes favoráveis à cultura de paz nas escolas, especialmente em comunidades situadas em bairros de elevado índice de violência. Entre os resultados obtidos, esteve a redução em

\footnotetext{
${ }^{90}$ Informações disponíveis em http://www.usp.br/nce/. Acesso em 27.06.2012.

${ }^{91}$ SOARES, Ismar. NCE - A trajetória de um núcleo de Pesquisa da USP. Comunicação \& Educação, ano 10, n. 1. São Paulo, ECA/USP, 2005. p. 111.
} 
$50 \%$ da violência nas escolas constatada em registros policiais, de acordo com declaração da Secretaria de Educação do Município. ${ }^{92}$

Trabalhando a linguagem audiovisual, foi desenvolvido também o Projeto Bemte-vi, viabilizado pela Secretaria de Cultura do Estado de São Paulo, com supervisão pedagógica do Núcleo. Entre os anos de 2006 e 2007, a iniciativa implantou núcleos de produção audiovisual em espaços públicos como escolas, centros comunitários e pontos de cultura. Os vídeos produzidos pelas mais de 500 crianças e adolescentes que passaram pelo projeto foram exibidos em diversos festivais de cinema nacionais e internacionais, ganhando inclusive prêmios em concursos de documentários.

O Núcleo também oferece referências teóricas aos interessados em pesquisar e discutir a interface entre comunicação e educação. As obras sugeridas pelo Núcleo abordam, entre outros temas, o jornalismo científico, informática, formação de professores, arte, movimentos cívicos e de garantia de direitos, infância e mídia, ficção, ciberespaço, televisão e educação a distância. ${ }^{93}$

\subsubsection{Entrevistas em Profundidade}

As entrevistas em profundidade, realizadas junto aos professores Adilson Citelli, Maria Aparecida Baccega, Maria Cristina Castilho Costa e Ruth Ribas Itacarambi, forneceram informações históricas e análises fundamentais para a construção do objeto de pesquisa. Os dados obtidos nesta etapa foram selecionados e distribuídos ao longo deste trabalho, em forma de citações ou como base para a construção do perfil da publicação. A íntegra do conteúdo das entrevistas pode ser consultado na seção Anexos.

\subsubsection{Análise de Enquadramento}

A análise de enquadramento foi utilizada, principalmente, como ferramenta de identificação das linhas gerais tratadas pelas seções Apresentação e, consequentemente, por cada número da revista de forma mais ampla. A seguir, os temas abordados em cada número e, em negrito, os assuntos que deram tom à edição - e que contribuíram,

92 SOARES in BIZONI, Alessandra Moura. Educomunicação, uma revolução na sala de aula. Folha Dirigida. Disponível em http://www.usp.br/nce/wcp/exe/public.php?wcp=/novidades/informe, 7,502. Acesso em 30.05.2011.

${ }^{93}$ Disponível em http://www.usp.br/nce/aeducomunicacao/saibamais/refbibliog/.

Acesso em 27.06.2012. 
também, para a análise da trajetória da própria revista.

\section{Apresentações}

Do mundo editado à construção do mundo

Número 1 - 1994 (Maria Aparecida Baccega)

A apresentação do primeiro número de Comunicação \& Educação, escrita por Baccega, explica os objetivos e o perfil da nova publicação - envolvendo especialmente a capacidade de edição do mundo - e discorre sobre as peculiaridades do espaço comum entre comunicação e educação. A televisão e o vídeo, como tecnologia discutida em diversas instâncias, merecem destaque nas reflexões dessa edição.

Os assuntos abordados pelo número de estréia são:

Artigo internacional-televisão

Crítica-filme brasileiro

Depoimentos - publicidade; influências do rádio sobre o grande público e sobre a televisão

Experiência - interpretação da mídia em sala de aula (jornais); comunicação (análise de diálogos)

Entrevista - Como se faz uma Campanha Política (com José Eduardo Mendonça)

Serviços - Vídeo e televisão

Boletim bibliográfico - vídeo e telenovela

Comunicação e tecnologia: educação e mercado de trabalho

Número $2-1995$

(Maria Aparecida Baccega)

A apresentação do segundo número da revista aprofunda a reflexão a respeito da mediação realizada pelos meios em relação aos fatos, centrando as discussões da edição nas interrelações tecnologia-sociedade-ideologia. Pela primeira vez, as tecnologias digitais são abordadas em um artigo que discute os rumos da imprensa escrita e sua credibilidade com a evolução da informática, por meio de um paralelo entre o jornal impresso e a televisão. Nas palavras de Baccega sobre o jornal eletrônico, "se não partirmos rapidamente para a discussão dessa nova modalidade, ela será apenas mais uma utilização da tecnologia para editar o mundo, de modo cada vez mais monossêmico, sem a garantia de pluralidade de pontos de vista, imprescindível ao próprio avanço dessa sociedade na construção de novas variáveis históricas". ${ }^{94}$

Continua também a série de artigos sobre cinema iniciada no primeiro número.

Entre os assuntos discutidos pela edição, estão:

Artigos nacionais- comunicações sobre o impacto da informática; a nova LDB e a formação de profissionais para a inter-relação comunicação/educação; vídeo e interpretação das mensagens na sala de aula; uso da televisão na educação e a recepção no programa de TV; história do cinema; narrativa nos quadrinhos; arte-educação.

Artigo internacional-televisão

Entrevista - TV educativa (com Roberto Muylaert)

Crítica-publicidade

Depoimentos - quadrinhos em sala de aula; processo criativo em literatura

Experiência - realização de jornal infantil; interpretação e transmissão de informações em sala

Serviços - jornal em sala de aula

Boletim bibliográfico - vídeo e telenovela ${ }^{94}$ BACCEGA, Maria Aparecida. Comunicação e Tecnologia: Educação e $\quad$ Mercado de
Trabalho.Comunicação \& Educação, ano 1, n. 2. São Paulo, ECA/USP, 1995. 
Comunicação, direitos humanos e cidadania

(Maria Aparecida Baccega)

A terceira edição dá ênfase especial à questão da cidadania e dos direitos humanos. O tema está presente em todos os aspectos da vida cotidiana, mesmo naqueles não aparentes, como é ressaltado no texto - e dentro dos quais "os meios de comunicação constituem a mediação cultural privilegiada, sintese entre tecnologia e cultura". ${ }^{95}$

Entre os assuntos discutidos nesta edição, estão:

Artigos nacionais-educação para a cidadania; teatro na educação (arte-educação); literatura juvenil (interpretação e formação); TV como política pública; jornal como instituição de educação.

Artigo internacional - rádio e educação

Entrevista - TV (com Nilton Travesso)

Crítica - cinema; telenovela; arte-educação

Depoimentos - cinema

Experiência - meios de comunicação em sala de aula (história)

Serviços - museu

Boletim bibliográfico - vídeo e telenovela

Comunicação e mediações

Número 4-1995

(Maria Aparecida Baccega)

"Este número da revista preocupou-se em mostrar um pouco até que ponto a identidade de cada um de nós - ponto de apoio para ajudar a construir a significação do que dizem os meios - é marcada pelas mediações, em ambos os níveis. "96

A apresentação faz uma retrospectiva dos temas relativos ao cinema, tratados nos números anteriores, destacando também alguns assuntos pela primeira vez - como o ensino a distância e a televisão a cabo. Pede ainda a participação do leitor por meio do envio de experiências de organizações que trabalhem com TV a cabo.

Os temas tratados na edição foram:

Artigos nacionais-cinema educativo; uma abordagem histórica; televisão; leitura em sala de aula; desafios da produção cultural e do ensino; videogravação em sala de aula; análise sobre teorias de classificação da informação; e "Tecnologias da informação e novos atores sociais", que aborda o gestor de processos comunicacionais como um profissional capaz de interagir nos campos da comunicação e da educação, ou seja, de Educomunicação.

Artigo internacional - ensino a distância e a televisão a cabo

Entrevista-cinema (com Carla Camurati)

Crítica - a linguagem no "fazer jornalístico"; comparação entre a televisão e a revista semanal

Depoimentos - bastidores da telenovela; teatro de bonecos

Experiência - "hora da curiosidade", dando voz ao aluno; Projeto de Leitura em sala de aula Serviços - museu e centros de artes; Ação Educativa

Boletim bibliográfico - videografia com referência literária; bibliografia sobre telenovela.

\footnotetext{
${ }^{95}$ BACCEGA, Maria Aparecida. Comunicação, Direitos Humanos e Cidadania. Comunicação \& Educação, ano 1, n.3. São Paulo, ECA/USP, 1995. p. 9.

${ }^{96}$ BACCEGA, Maria Aparecida. Comunicação e mediações. Comunicação \& Educação, ano 2, n. 4. São Paulo, ECA/USP, 1995. p. 8.
} 
Comunicação e cultura

(Maria Aparecida Baccega)

Essa edição da revista aborda a nova realidade da comunicação a partir das seguintes perguntas:

- Há distinção entre comunicação e mídia?

- Como (e quem) desenha o mundo que chega ao nosso conhecimento, contando-nos o que ocorre?

- Quem pauta os assuntos da agenda que discutimos no nosso cotidiano? ${ }^{97}$

A partir destas questões, apresenta os artigos que formam o número. Os assuntos educação a distância e educação ambiental aparecem pela primeira vez. Os temas da edição foram:

Artigos nacionais-indústria da mídia e seus efeitos; terceirização de equipes em agência de notícias; agenda setting e educação; educação a distância; educação ambiental; discussão sobre o ensino universitário.

Artigo internacional - educação para o desenvolvimento

Entrevista - cinema e teatro (com Gianfrancesco Guarnieri)

Crítica - comunicação pública e rádio

Depoimentos - livro; rádio na esfera dos profissionais de comunicação

Experiência-trabalho interdisciplinar envolvendo arte, português e história

Serviços - museu e televisão

Boletim bibliográfico - telenovela; comunicação e educação

Meios de comunicação: dos homens para os homens

Número 6 - 1996

(Maria Aparecida Baccega)

A edição traz questões fundamentais para entender a comunicação em época de eleições: qual o papel do estado na chamada modernidade? Quais os direitos dos cidadãos? O que é ser cidadão e quem consegue ser cidadão no Brasil? Como os meios de comunicação aparecem nesse projeto de Estado? Qual deve ser seu papel na formação de homens que sabem que têm direitos e que consigam reivindicá-los? E propõe a dessacralização dos meios par que se possa compreendê-los como instrumentos a serviço de políticas benéficas ou não para a sociedade.

À época da publicação deste número, começava-se a discutir os efeitos da chamada globalização enquanto fenômeno contemporâneo, que se aventava como um risco potencial de perda de identidades ou, alternadamente, do acirramento de conflitos num novo contexto. Interessante observar como essas questões evoluíram ao longo dos 15 anos seguintes.

O tema "educação pela internet" é abordado pela primeira vez "como um espaço novo (e potencialmente poderoso) para ativismos políticos de todos os tipos e colorações" 98 apontando para a importância da seleção de informações entre um mar de dados. Também a seção Experiência discute o computador na sala de aula.

Os assuntos discutidos na revista foram:

Artigos nacionais - rádio na educação; televisão relacionada a prioridades e evasão educacional; qualidade de ensino no jornalismo; educação pela internet; pesquisa de recepção e educação para os meios.

Artigo internacional - viés dos estudos da telenovela no Brasil e América Latina

Entrevista - Projeto TV Escola (com Isa Grinspum Ferraz)

Crítica-publicidade; literatura

Depoimentos - fazer teatral; imprensa sindical

Experiência-informática em sala de aula: o que, como e por que fazer

Serviços-Cinema e TV; Educação

Boletim bibliográfico - telenovela; comunicação e educação.

\footnotetext{
${ }^{97}$ BACCEGA, Maria Aparecida. Comunicação e cultura. Comunicação \& Educação, ano 2, n. 5. São Paulo, ECA/USP, 1996. p. 9.

${ }^{98}$ BACCEGA, Maria Aparecida. Meios de Comunicação: dos homens para os homens. Comunicação \&
}

Educação, ano 2, n. 6. São Paulo, ECA/USP, 1996. p. 10. 
Número $7-1996$

Tecnologia, escola, professor

(Maria Aparecida Baccega)

Nesta apresentação, Baccega comenta o fato de que, nos tempos atuais, o escrivão português Pero Vaz de Caminha enviaria um fax para a Coroa Portuguesa, encurtando o senso de "imediatamente" que, até então, significaria um periodo de meses - e questiona o temor de substituição do professor por recursos tecnológicos como o computador, o vídeo ou a televisão. Fala, ainda, da importância de se saber "ler" e inter-relacionar esses produtos, garantindo o espaço de reflexão que é e continuará sendo a escola, sob a coordenação do professor. Defende a importância da tecnologia como formadora de cidadãos, assim como a retomada do papel do educador, de ensinar com criticidade - uma necessidade reafirmada de maneira definitiva, responsável por tornar o aluno em sujeito na História com a ajuda de novas ferramentas.

O tema do meio ambiente é abordado também pela primeira vez.

Entre os assuntos da edição, estão:

Artigos nacionais- necessidade de valorização do professor; multimídia na educação, destacando a importância do uso das tecnologias, sobretudo do CD-Rom; dimensão social do meio ambiente; quadrinhos; relação entre mídia e violência.

Artigo internacional - impacto moral e social dos meios de comunicação

Entrevista - Jânio de Freitas, sobre a evolução do jornalismo

Crítica - diferenças entre telenovela e minissérie; cinema nacional

Depoimentos - Rosicler Martins, autora de livros paradidáticos, explica seu processo de criação

Experiência - trabalho com poesia em sala de aula

Serviços - rádio USP; Museu de Anatomia Veterinária

Boletim bibliográfico - telenovela; comunicação e educação.

Número $8-1997$

Televisão: desafio permanente

(Maria Aparecida Baccega)

Este número é dedicado principalmente à televisão, que, com seus produtos noticiosos ou dramatúrgicos, modificou a maneira de a audiência lidar com a informação. A questão é abordada também pelo viés da identidade cultural brasileira, especialmente à luz da chegada das TVs a cabo. Estariam os programas estrangeiros colaborando para a perda da identidade nacional? A questão fica aberta, inclusive, em relação à capacidade "antropofágica" de observarmos o mundo. Mais uma vez, manifesta-se a importância da formação de cidadãos críticos, que possam mobilizar conhecimentos e manifestar os critérios culturais de identificação de seus valores.

A edição traz também um importante anúncio: a criação da homepage da revista, "rompendo barreiras, levantando fronteiras e colocando-se ao acesso dos que quiserem". ${ }^{99}$

Os temas abordados neste número são:

Artigos nacionais- relações entre $\mathbf{T V}$ e política; inter-relação comunicação/educação no sistema de ensino à luz da nova LDB; escola e discursos não-didáticos (com envolvimento dos alunos na produção destes); comparação entre heróis do videogame e heróis tradicionais e a importância desta tecnologia na vida dos alunos.

Artigo internacional - violência nos meios de comunicação

Entrevista - educação para a elite X educação para a maioria (com referências ao PCN), com Dermeval Saviani

Crítica - estética na telenovela

Depoimentos - trajetória de um dramaturgo

Experiência-MPB na sala de aula como elemento de aproximação professor-aluno

Poesia - Pablo Neruda (relação com o filme lançado à época, O Carteiro e o Poeta)

\footnotetext{
${ }^{99}$ BACCEGA, Maria Aparecida. Televisão: desafio permanente. Comunicação \& Educação, ano 3, n. 8. São Paulo, ECA/USP, 1997. p. 13.
} 
Serviços - IEA; Instituto Astronômico e Geofísico da USP; Ensino e Educação com Igualdade de Gênero (Nemge).

Boletim bibliográfico - telenovela; comunicação e educação.

Número 9 - 1997

Comunicação na educação formal: processo de mudança

(Maria Aparecida Baccega)

Este número trata dos processos de mudança verificados na educação formal, especialmente ligados à introdução da televisão no meio escolar. Destaca a necessidade de políticas públicas que possibilitem o acesso dos diferentes segmentos sociais à comunicação e que, nesse âmbito, estimulem o trabalho para uma política de comunicação dirigida à educação formal.

Os temas abordados na edição foram:

Artigos nacionais-políticas sociais e direitos sociais no Brasil; formação de professores em tempos de informática (tema tratado pela primeira vez); projeto governamental para formação e capacitação de professores; linguagens audiovisuais e cidadania; utilização de filmes nas aulas de história.

Artigo internacional - Comunicação Plural: alteridade e sociabilidade

Entrevista - José Wilker, sobre cinema

Crítica-telenovela; poesia sobre cultura amazônica

Depoimentos - Paulo Caruso (charges)

Experiência - aulas de matemática e geometria envolvendo informática; oficina de contos clássicos

Poesia - Jorge Andrade

Serviços - Núcleo de Estudos da Violência da USP

Boletim bibliográfico - telenovela; comunicação e educação.

Número $10-1997$

\section{A história no campo da comunicação/educação}

(Maria Aparecida Baccega)

A apresentação deste número reflete sobre a forma como a história é interpretada através dos tempos, definindo a linguagem, citando Adam Schaff, como "prática social solidificada". Para formar cidadãos críticos, é importante a relação estabelecida com os meios de comunicação, buscando compreender seus mecanismos - já que a educação é um processo social no qual imergimos ao nascer, principalmente através da palavra. A história não pode ser vista como um encadeamento de conhecimentos estáticos, mas como um processo que influencia de forma determinante o presente, $e$ onde o futuro também está contido idealmente. Pela primeira vez, trata também da assessoria de imprensa dentro deste processo, na seção Depoimento. A partir deste número, a discussão conceitual e teórica passa a ser mais extensa também entre os textos da seção Apresentação - que passa a obedecer a estrutura de artigo, contendo resumo e palavras-chave.

Os temas abordados na edição foram:

Artigos nacionais- história pensada a partir da contemporaneidade, com ênfase na construção da imagem; comunidade e escola, memória e produção cultural (escola como centro de cultura para professores, alunos e comunidade); educação e tradição marxista no Brasil; identidade afro-brasileira - abordagens do ensino e da arte; desafios da relação museu-escola. Artigo internacional - Professor e meios de comunicação: desafios, estereótipos e pesquisas. Entrevista - Mário Fanucchi, inventor do "indio" da TV Tupi, fala sobre a televisão de 1945 até os dias atuais.

Crítica - relação entre ficção e realidade, bem como sobre autonomia da arte à luz do filme $\mathrm{O}$ que é Isso, Companheiro?

Depoimentos - assessoria de imprensa e processo informativo.

Experiência - produção de revista por alunos de sexta série, aliada ao conteúdo programático

Poesia - Patativa do Assaré

Serviços - Instituto de Estudos Brasileiros da USP

Boletim bibliográfico - revolução industrial; telenovela; comunicação e educação. 
Conhecimento, informação e tecnologia

Número 11 - 1998

(Maria Aparecida Baccega)

Neste texto de apresentação, Baccega traça um panorama da comunicação como sustentáculo da realidade, analisando sua relação com o desenvolvimento econômico e social da história do próprio homem. Fala ainda da necessidade e das formas possíveis de transformar a informação em conhecimento, processo que implica em crítica e está baseado na inter-relação e não na fragmentação. De acordo com a autora, a informação não pode, ela própria, ocupar o lugar do conhecimento, tornando-se uma mercadoria a mais - e, nos tempos atuais, a base para a reprodução do sistema, sujeita inclusive à espetacularização. "Comunicação é produção social de sentido. E esse sentido se constrói nas relações sócio-históricas dessa sociedade pósindustrial. $" 100$ Como sempre, nesse processo a escola tem papel fundamental.

Destaque para o artigo internacional de Martín-Barbero, abordando os novos ambientes da comunicação - que, segundo a autora, "serve de cenário para a leitura deste número e de chave para o conhecimento da contemporaneidade". ${ }^{101}$ Também para a abordagem, pela primeira vez, de uma iniciativa de responsabilidade social privada, na seção Serviços. Outro tema importante da edição é o Congresso Internacional realizado pelo Núcleo de Comunicação e Educação da ECA/USP.

Os temas abordados na edição foram:

Artigos nacionais-o jornal e o jornalista de amanhã; jornalismo didático e agenda do leitor; gestão da comunicação no desenvolvimento regional; adolescente diante da telenovela; terceira idade e tecnologia.

Artigo internacional - Cidade virtual: novos cenários de comunicação.

Entrevista - Beth Carmona, diretora de Programação da TV Cultura, sobre TV Educativa no Brasil.

Crítica - A crítica de Adilson Citelli sobre o filme Guerra de Canudos, de Sérgio Rezende, aborda também as mudanças pelas quais passou a comunidade durante a elaboração do filme.

Depoimentos - Paulo Augusto de Silva, ex-editor de Encartes, suplemento cultural do Jornal de Natal, sobre a importância da prática do jornalismo regional.

Experiência - trabalho em produção de textos referenciado pela obra de Graciliano Ramos, voltado a alunos da terceira série do Ensino Fundamental.

Poesia - Santa Clara, padroeira da Televisão (Caetano Veloso)

Serviços - Programa Moto Perpétuo da Fiat; Congresso Internacional realizado pelo Núcleo de Comunicação e Educação da ECA/USP.

Boletim bibliográfico - telenovela; comunicação e educação.

\section{Recepção: nova perspectiva nos estudos de comunicação (Maria Aparecida Baccega)}

Nesta apresentação, Baccega fala da importância do diálogo na comunicação, destacando que, para avaliá-lo, não é necessário apenas focar o olhar na recepção das mensagens, mas também em sua emissão - considerando o receptor não como simples decodificador de mensagens, mas também como produtor de significações. Sob este aspecto, o papel da escola se redefine, não bastando falar da educação para os meios como se estes fossem trazidos de fora, mas sim trabalhar a construção de sentidos sociais a partir do encontro entre produtos midiáticos $e$ receptores.

Os temas abordados na edição foram:

Artigos nacionais - jornal na escola: da informação à opinião esclarecida; leitura da obra de Frida Kahlo; leitura da recepção de audiovisual (cinema e vídeo); estética da violência, real e fictícia, nos meios e recepção a ela (com ênfase na ditadura militar).

Artigo internacional - recepção: a abordagem dos estudos culturais.

\footnotetext{
${ }^{100}$ BACCEGA, Maria Aparecida. Conhecimento, informação e tecnologia.Comunicação \& Educação, ano 5, n. 11. São Paulo, ECA/USP, 1998. p. 9.

${ }^{101}$ Idem, p. 14.
} 
Entrevista - com Guillermo Orozco

Crítica - livro de memórias - Tiradentes: um presídio da ditadura.

Depoimentos - José Carlos Ruy - Arquivo como base do trabalho jornalístico

Experiência - língua e informática; ensino e pesquisa no segundo grau.

Poesia-Cecília Meireles

Serviços - TV USP

Boletim bibliográfico - telenovela; comunicação e educação.

Número 13 - 1998

\section{O estereótipo e as diversidades}

(Maria Aparecida Baccega)

Nesta apresentação, Baccega discute o conceito de estereótipo, destacando seu sentido ligado ao preconceito e ao senso comum - disfarçado, nesse caso, simplesmente de "conceito", aspecto bastante explorado pelos meios de comunicação - e passado de geração a geração. Ressalta também, no entanto, a capacidade de se utilizar a elaboração de estereótipos a nosso favor, lembrando que eles também podem ajudar a agilizar nossa percepção do mundo. A diferenciação na forma pela qual se empregam os conceitos pré-elaborados acontece quando são oferecidas, ao indivíduo, possibilidades reais de inserção na sociedade e quando ele se torna efetivamente sujeito, tendo sua voz respeitada - mais uma vez, tendo a escola como pilar fundamental desse processo.

Os temas abordados na edição foram:

Artigos nacionais - multiculturalismo; desafios comunicacionais no Mercosul; dilemas éticos no campo da violência; comunicação dirigida nas escolas.

Artigo internacional - tendências nos estudos da recepção.

Entrevista - Maria Thereza Fraga Rocco - Escola, meios de comunicação e a relação professor-aluno.

Crítica-Telenovela: arte do cotidiano.

Depoimentos - Sérgio de Souza, editor da revista Caros Amigos

Experiência - aulas de culinária para crianças

Poesia - Frederico García Lorca

Serviços - Instituto Moreira Salles

Boletim bibliográfico - história, poesia e cinema como elementos de transformação social; telenovela; comunicação e educação.

\section{A construção do campo comunicação/educação}

Número 14 - 1999

\section{(Maria Aparecida Baccega)}

A transversalidade vem discutida com destaque neste número, apresentado pela prof. Baccega. Entre as questões destacadas pelo artigo, estão a dificuldade de elaboração de pesquisas sobre os meios, negando-lhes prestígio - e, em conseqüência, financiamento - e o mercado dos bens simbólicos como lugar de reconhecimento do campo cultural. Vê, ainda, o campo da comunicação como espaço de construção da cidadania, por meio da inserção e do desenvolvimento da criticidade do mundo editado. Nesse sentido, discute também o objetivo da própria revista, que contribui para a construção do campo comunicação/educação num movimento que percorre, permanentemente, o todo e as partes em intercâmbio constante, com os olhos da congregação da escola e dos meios.

O artigo faz ainda uma reflexão a respeito do uso da internet como parte dos novos paradigmas educacionais, alertando para que este recurso não venha a se tornar um paliativo ou "jogada de marketing" dentro de um sistema ineficaz - e analisa, ainda, alguns dos problemas de infraestrutura nacional ligados às dificuldades de popularização da internet, como a falta de linhas telefônicas, por exemplo. Aborda também a questão da educação ambiental e do risco da simplificação do tema nas escolas, deixando de relacioná-la com as áreas de economia, sociedade, política e ecologia - como quer a UNESCO e os demais órgãos nacionais de educação.

Os temas abordados na edição foram: 
Artigos nacionais - internet no ensino; transdisciplinaridade: o desafio de inovar; comunicação, ensino e temática ambiental; ensino e arte nos EUA e no Brasil; arte-educação, ética e estética.

Artigos internacionais - ensino, multimídia e globalização; processos educativos e canais de comunicação.

Entrevista - Eva Wilma; importância da dramaturgia.

Crítica - novo cinema brasileiro.

Depoimentos - Ricardo Kotscho, sobre jornalismo e grande imprensa

Experiência - aborto nas aulas de sociologia

Poesia-Bertold Brecht

Serviços - Centro de Cibernética Pedagógica

Boletim bibliográfico - meio ambiente e ensino fundamental (videografia); telenovela; comunicação e educação.

Número 15 - 1999

Comunicação/educação e transdisciplinaridade: os caminhos da linguagem

(Maria Aparecida Baccega)

Nesta apresentação, Baccega discute novamente a questão da transdisciplinaridade e a forma como a comunicação se constitui a partir dela. O intercâmbio de saberes é a chave para transitar entre as diversas fronteiras dos campos do conhecimento, indo contra a ideia da realidade compartimentada. A autora cita a conjunção entre os discursos da história e da literatura como principais formadores do discurso da comunicação, constituído, basicamente, da linguagem verbal. A democratização desse discurso, que seleciona, edita e interpreta os fatos do cotidiano, passa pela escola que, ressignificada, torna-se espaço de transformação da informação fragmentada em conhecimento.

Os temas abordados na edição são:

Artigos nacionais - Sociedade Informacional; Tratamento de imagens na formação do Pedagogo; Programas educativos na TV; Educação, cultura e cidadania: comunicações na periferia; trabalho teatral realizado no Marrocos.

Artigos internacionais - Comunicação/educação na formação profissional.

Entrevista - Jesús Martín-Barbero; Sujeito, comunicação e cultura.

Crítica - ciência na programação da TV comercial, com foco no programa Globo Ciência.

Depoimentos -Chico Pinheiro. Telejornalismo, ética e cidadania

Experiência - ojornal e a notícia nas aulas de português

Poesia-Manuel Bandeira

Serviços - Museu do Ipiranga

Videografia - ética e meios de comunicação, por meio da análise de filmes nacionais

Boletim bibliográfico - telenovela; comunicação e educação.

Ressignificação da escola: a circulação da ideologia

(Maria Aparecida Baccega)

Nesta apresentação, Baccega aborda a ideologia como práxis social, ou conjunto de representações e normas que encontram lugar privilegiado em todo o mundo, sobretudo por meio dos veículos de comunicação. Entre os muitos aspectos discutidos em relação à ressignificação da escola, o texto aponta a ideologia como tema importante do ponto de vista da construção de sentido, cotidiano e circulação de formas simbólicas - abordagens que podem servir, também, como roteiro de discussão da temática. "A função da ideologia é a de apagar as diferenças como as de classes e de fornecer aos membros da sociedade o sentimento da identidade social, encontrando certos referenciais identificadores de todos e para todos, como, por exemplo, a Humanidade, a Liberdade, a Igualdade, a Nação ou o Estado". 102

Os temas abordados na edição foram:

${ }^{102}$ BACCEGA, Maria Aparecida. Ressignificação da Escola: a circulação da ideologia. Comunicação \& Educação, ano 6, n. 16. São Paulo, ECA/USP, 1999, p. 8. 
Artigos nacionais - Jacques Marcovitch, então reitor da USP, sobre os valores que permeiam a ação acadêmica; computador para interação comunicativa; virtualização da realidade; espaço para a produção de conhecimento na escola; encenação da educação nas cartas de leitores (influência da imprensa no que é discutido pela sociedade).

Artigos internacionais - rádio: história e abrangência na era digital.

Entrevista - comunicação e interesse público - Armand Mattelart.

Crítica-TV, um poder sem controle.

Depoimentos - jornalismo científico nas ondas do rádio

Experiência-exercícios com jornais; matemática a partir de folheto de publicidade

Poesia-Fernando Pessoa

Serviços - Estação Ciência

Videografia - Brasil 500 anos?

Boletim bibliográfico - telenovela; comunicação e educação.

Número 17 - 2000

Mediação organizativa: o campo da produção

(Maria Aparecida Baccega)

Aqui, a autora aproveita o tema dos 500 anos de descoberta ou chegada ao Brasil para discutir a questão do ponto de vista presente de um relato, seja ele histórico ou midiático. Analisa a seleção dos temas abordados pelos meios já desde a elaboração da pauta, passando pelo enquadramento que se dá a cada informação - discutindo as principais características da mediação organizativa no âmbito da produção midiática, envolvendo interesses empresariais, comerciais e políticos. Por meio dessa discussão, propõe a relativização da independência do sujeito/receptor.

A partir desta análise, a edição vem focada no desenvolvimento dos temas pela mídia e suas nuances:

Artigos nacionais - Discurso da propaganda e diretrizes curriculares; meios de comunicação e práticas escolares; estudo de recepção para a crítica da comunicação; imagens da guerra: do horror à sedução; ética e meios de comunicação; telenovela e educação: um processo interativo.

Artigos internacionais - Audiência: uma abordagem sociológica da comunicação; Educação para os meios na Itália; Recepção infantil da obra teatral.

Entrevista - comunicação e interesse público - Lauro César Muniz

Crítica - Eugênio Bucci: análise do programa Linha Direta como uma das faces de um Estado policial e totalitário

Depoimentos - João Antônio Batista, sobre trajetória no rádio

Experiência - poesia e meio ambiente; jornal na escola como ferramenta de autoestima (feito pelos alunos)

Poesia - João Cabral de Melo Neto

Serviços - Manifesto 2000, por uma cultura de não-violência; Centro de Estudos das Relações de Trabalho e Desigualdades

Videografia-Brasil: 500 anos de que história?

Novas tecnologias, novas sensibilidades

Número $18-2000$

(Maria Aparecida Baccega)

Baccega discute, aqui, as mudanças culturais advindas do processo de globalização, assim como a discussão a respeito das crises de identidade ligadas ao pertencimento territorial. Contemporaneamente, as novas tecnologias, a facilidade do fluxo de informações e a comunicação criam novas formas de relacionamento com o outro, especialmente entre os jovens - o que aprofunda os desafios enfrentados pela a escola e pelo professor. Dessa forma, o texto ressalta a importância de se compreender as novas tecnologias e meios de comunicação a partir da recepção, já que seus significados se constroem no cotidiano.

Os temas abordados na edição foram: 
Artigos nacionais - Novas tecnologias no contexto escolar; Rádio a serviço da comunidade; TV Comunitária nos EUA; Influências socioculturais na escolaridade de conscritos. Artigos internacionais - Desafios culturais da comunicação à educação; Teleaudiências: premissas para uma pedagogia.

Entrevista - Identidades culturais no contexto da globalização

Crítica - Cinema nacional: táticas para um tempo sem estratégias

Depoimentos - Fascínio de trabalhar com livros

Experiência - Exercício da dúvida no trabalho interdisciplinar (meio ambiente)

Poesia-Cora Coralina

Serviços - Newsware: proposta pedagógica de educação para a mídia

Videografia - telenovela; comunicação e educação.

Número 19 - 2000

Televisão: 50 anos

(Maria Aparecida Baccega e Marluce E. Carvalho Zacariotti)

$O$ artigo destaca o $50^{\circ}$ aniversário da televisão no Brasil, ressaltando a importância desse veículo ao dar visibilidade aos fatos sociais, constituindo-se em mediadora privilegiada da realidade e, inclusive, do espaço público. As autoras Maria Aparecida Baccega e Marluce E. Carvalho Zacariotti salientam os desafios que a TV nos coloca permanentemente - e como o campo comunicação/educação pode ajudar a enfrentá-los, oferecendo instrumentais para que se tenha uma visão menos fragmentada dos fatos sociais. As autoras relacionam, ainda, toda a bibliografia publicada sobre o tema televisão nos seis anos de existência da revista Comunicação \& Educação.

Os temas abordados na edição foram:

Artigos Nacionais - Educomunicação: um campo de relações; Ação política e propaganda eleitoral: instrumentos da democracia; Apontamentos sobre a crítica de TV; Apreciação e interatividade.

Artigos internacionais - Globalização da comunicação.

Entrevista - Propaganda política, jornalismo e construção da agenda pública (com Luís Gonzalez).

Crítica - Produção de sentido: elo entre comunicação e educação

Depoimento - Desafios da comunicação institucional na administração pública

Experiência - Meio ambiente como tema transversal; Jornal como proposta de educação para a cidadania

Poesia - Thiago de Mello

Serviços - LAPIC: Espaço lúdico de produção de conhecimento sobre TV/criança; Vídeo no Museu de Anatomia e Veterinária da USP

Videografia - telenovela; comunicação e educação.

Comunicação/Educação: conhecimento e mediações

Número 20 - 2001

(Maria Aparecida Baccega)

Baccega discute, aqui, a importância do conceito das mediações para a compreensão do processo de conhecimento da realidade. Afirma a necessidade de transdisciplinaridade como possibilidade de apreensão do real, reforçando o fato de que a realidade é mais do que apenas uma área ou um grupo de áreas da ciência. Destaca, ainda, o campo comunicaçãoleducação como espaço de convergência de saberes sensiveis às mediações presentes nas relações sociais - que são também históricas e culturais.

Os temas abordados na edição foram:

Artigos nacionais - Comunicação e educação: a perspectiva do receptor; mundo do trabalho e educação a distância; jornal escolar: inter-relação criativa; marketing católico: resposta à concorrência pentecostal.

Artigos internacionais - desafios da comunicação global; Sociedade da informação: políticas da União Européia

Entrevista-Educação: os valores e as pessoas 
Crítica - Impasses na música popular brasileira

Depoimentos - Jornalismo versus pensamento único

Experiência - Autoestima para apropriação do saber (com teatro, televisão e cinema)

Poesia - Sérgio Caparelli

Serviços - Site da Estação Ciência (internet na escola)

Videografia-História de Personagens da História

Boletim bibliográfico - telenovela; comunicação e educação.

Número $21-2001$

Da comunicação à comunicação/educação

(Maria Aparecida Baccega)

Nesta apresentação, a autora aborda a constituição da interface comunicação/educação, destacando sua origem no campo da comunicação, caracterizada pelo embate entre os diferentes discursos sociais - e cenário para a configuração dos processos de edição da realidade mediada pelos meios. Baccega define a comunicaçãoleducação como metassignificação de um novo espaço teórico, marcado pela transdisciplinaridade $e$ fundamental para a formação de cidadãos - objetivo primeiro da escola.

Neste número, a revista passa a publicar também a seção Endereços úteis na internet, trazendo links de interesse para o trabalho em sala de aula.

Os temas abordados na edição foram:

Artigos nacionais - Escola e televisão: para além dos antagonismos; Da imagem pedagógica à pedagogia da imagem; Multiculturalismo e identidade: o papel dos meios de comunicação; Compositor musical e professor: uma visão comparativa; Ciberespaço e violência simbólica.

Artigos internacionais - Avaliação de metodologias na educação para os meios

Entrevista - Por uma TV de vanguarda (com Fernando Faro)

Crítica - Venturas e desventuras do teatro brasileiro

Depoimentos - Maísa Zakzuk, que dirige o X-Tudo e outros programas da TV Cultura

Experiência-Diversidade de linguagem no trabalho didático (como foco em meio ambiente)

Poesia - Carlos Drummond de Andrade

Serviços - Fundação Seade

Videografia - trabalho em sala de aula através da pesquisa

Boletim bibliográfico - telenovela; comunicação e educação; endereços úteis na internet.

Número $22-2002$

Da informação ao conhecimento: ressignificação da escola (Maria Aparecida Baccega)

Baccega trata da importância da seleção crítica das informações que circulam na sociedade dentro do processo de aquisição do conhecimento. Destaca, também, o contexto da sociedade globalizada pela lógica do capitalismo tardio e multinacional, que aprofunda ainda mais as desigualdades socioeconômicas dos povos dos diferentes países - tendo, em sua ideologia própria, uma aliada na transformação de pontos de vista particulares em regra geral. Nesse sentido, a autora ressalta o papel dos meios de comunicação como mediadores entre o homem e a realidade - já que o espetáculo e a padronização são lógicas mercantis importantes para a circulação dos bens culturais na sociedade capitalista. Dentro deste cenário, a escola apresenta-se como a instituição que, ressignificada, desempenha função fundamental na formação de cidadãos capazes de desvelar as ideologias que circulam nos meios de comunicação.

Os temas abordados neste número são:

Artigos nacionais - Futuros e utopias da modernidade; Indústria Cultural: Bourdieu e a teoria clássica; Ética e estética na programação infanto-juvenil; Aplicações da História em Quadrinhos; Um professor de matemática na ECA.

Artigos internacionais - Comunicação: identidade e identidades em Portugal

Entrevista - Mário Lago

Crítica-Cabrião: humor e paródia política

Depoimento - Neide Duarte, diretora do programa Caminhos e Parcerias 
Experiência - proposta de leitura e escrita de melodias

Poesia-Raquel Naveira

Serviços - Milú Vilella fala sobre o MAM

Videografia-escrita como tema de pesquisa

Boletim bibliográfico - telenovela; comunicação e educação; endereços úteis na internet.

Número 23 - 2002

\section{Comunicação: interação recepção/emissão}

(Maria Aparecida Baccega)

Nesta apresentação, a autora discute a importância da comunicação, evidenciando-a como processo mediado pela cultura e pela realidade de cada receptor - e mostrando o receptor não como um mero reprodutor das informações, mas como agente de um processo de interação no qual a circulação das formas simbólicas pressupõe um campo comum de significados. Dessa forma, cresce também a importância e a responsabilidade dos produtores das mensagens incluindo a escola enquanto responsável pelo amadurecimento intelectual e crítico das novas gerações.

Fazem parte desta edição:

Artigos nacionais - Gestão Comunicativa e Educação: caminhos da Educomunicação; política cultural na contemporaneidade; Funk: grito por espaços de convivência; apontamentos para o estudo da narrativa.

Artigos internacionais - Comunicação, Educação e novas tecnologias: tríade do século XXI

Entrevista - Mino Carta

Crítica - Bicho de Sete Cabeças - um grito de alerta (filme); Havana por lentes sujas (livro)

Depoimento - Heliodoro Bastos (charges)

Experiência-Jornal,jogos e brincadeiras

Poesia - Mário de Andrade

Serviços-Educom.rádio

Videografia - filmes sobre educação e infância

Boletim bibliográfico - telenovela; comunicação e educação; endereços úteis na internet.

Televisão e educação: a escola e o livro

Número $24-2002$

\section{(Maria Aparecida Baccega)}

Neste artigo, Baccega trata das linguagens audiovisuais, principalmente da televisão, no espaço da escola. Após uma rápida introdução sobre a chegada da TV no Brasil e sua presença no dia-a-dia da população, alerta os educadores a respeito do desafio do conhecimento e do ensino através da incorporação da linguagem audiovisual - já que o livro e a linguagem escrita, embora continuem sendo a chave da primeira alfabetização e de entendimento posterior do mundo não-verbal, não são capazes de abarcar, sozinhos, a dinâmica de todas as formas de conhecimento que circulam na sociedade. A autora defende também a inclusão da televisão como fonte de educação, sendo vista pela escola não apenas como "ilustradora" das aulas baseadas na linguagem escrita, mas como veículo que amplia as linguagens do aprendizado já anteriores à sala de aula.

Nesse número, a revista passa a trazer uma nova e importante seção: a de aplicações de atividades em sala de aula, baseadas no conteúdo de cada edição, feita por Ruth Ribas Itacarambi.

Fazem parte desta edição:

Artigos nacionais - Citações epistemológicas no campo da Educomunicação; TV como instância de letramento; Criatividade e tecnologia no mundo da representação.

Artigos internacionais - Status da pesquisa sobre crianças e televisão; citações epistemológicas no campo da Educomunicação

Depoimento - Renato Tapajós - Ofício de documentarista ou olho da câmera não mente

Entrevista - Ruy Guerra

Crítica - reality shows; Campanha Amigos da Escola (publicidade que induz a pensar em biblioteca à disposição dos estudantes) 
Experiência - Leitura e compreensão da bula de remédio

Poesia - Oswald de Andrade

Serviços - Bairro da Luz: passeio pela arte brasileira

Videografia - filmes sobre papel da escola e do professor, intolerância e marginalização

Boletim bibliográfico - telenovela; comunicação e educação; endereços úteis na internet.

Número 25 - 2003

Meios de comunicação na escola

(Maria Aparecida Baccega)

Neste artigo, Baccega discute a presença dos meios de comunicação e das novas tecnologias na escola, partindo da polêmica entre aqueles que se posicionam favoravelmente e os que são contrários a ela - para reafirmar que o fenômeno, na verdade, independe de opinião ou vontade, sendo já uma realidade no cotidiano e na cultura de alunos e professores. $O$ verdadeiro desafio, na verdade, reside em saber utilizá-las para uma educação adequada aos tempos atuais de cultura midiática, em que a escola deve assumir papel de mediação e formação de cidadãos críticos, que saibam pensar e escolher por si próprios.

Na seção de artigos internacionais, a edição discute a preocupante divisão entre pobres e ricos também no mundo informático, comparando, por exemplo, os investimentos feitos na área pelos EUA e pelo Chade.

Fazem parte desta edição:

Artigos nacionais - Informática na educação especial; Telenovela e vida cotidiana; Emoções e sentimentos: polêmicas sobre o ensino de arte.

Artigos internacionais - Sistemas educativos entre máquinas e redes

Entrevista - Ruth de Souza, atriz

Crítica - crítica ao filme Exodus, sobre a questão judaico-palestina

Depoimento - Rita Amorim, assessora de imprensa do Hospital do Coração do Hospital das Clínicas e especialista em gestão de processos comunicacionais

Experiência-Educação para os meios: um projeto com vídeo

Poesia - Vinicius de Moraes

Serviços - Memorial do imigrante

Videografia - exercícios sobre a arte do cinema

Boletim bibliográfico - telenovela; comunicação e educação; endereços úteis na internet.

Narrativa ficcional de televisão: encontro com os temas sociais

Número $26-2003$ (Maria Aparecida Baccega)

Neste artigo, Baccega discute o potencial narrativo da telenovela - gênero que, há muito, influencia e é influenciado pela cotidianidade brasileira $-e$ de outros produtos da ficção televisiva. De acordo com a autora, a linguagem da televisão, em termos amplos, também pode ser considerada educativa, estando por vezes mais sintonizada com a realidade do que o próprio discurso jornalístico - recuperando, por exemplo, os mitos presentes nas histórias contadas nas praças, feiras e livros como parte de diferentes culturas.

Fazem parte desta edição:

Artigos nacionais - Telenovela brasileira: uma narrativa sobre a nação; Novas práticas curriculares na educação a distância.

Artigos internacionais - Tecnologia digital: perspectivas mundiais

Entrevista - Heloisa Dupas Penteado

Crítica - O que a ficção pode fazer pela realidade?; Cidade de Deus - online; Os Sertões: uma epopéia educadora de 100 anos.

Depoimento - Pedro Vaz (rádio)

Experiência - Na escola com as histórias em quadrinhos

Poesia-Carlos Drummond de Andrade

Serviços - curso Linguagem audiovisual na escola - uma ação educomunicativa

Videografia - processos de ensino-aprendizagem baseados em cinco diferentes filmes

Boletim bibliográfico - telenovela; comunicação e educação; endereços úteis na internet. 
Tecnologia e construção da cidadania

(Maria Aparecida Baccega)

Baccega discute, nesta apresentação, a função das novas tecnologias na construção da cidadania, salientando que elas, por si só, não caracterizam um ensino de qualidade, mas sim quando são utilizadas dentro de projetos adequados à formação do aluno como cidadão crítico. Elas seriam, nesse sentido, recursos para favorecer e ampliar o ensino de qualidade contribuindo para o crescimento em rede, o intercâmbio e o compartilhamento de ideias $e$ informações.

Fazem parte desta edição:

Artigos nacionais - Filosofia de Paulo Freire e práticas cognitivas no jornalismo; Ética e cinema: notas sobre uma experiência didática; A inter-relação entre criança e $\mathbf{T V}$

Artigos internacionais - Material Educativo: a experiência de aprendizado; Receptores mais críticos

Entrevista - Gabriel Priolli, sobre televisão educativa

Crítica - Educação a distância

Depoimento - Especialista em Gestão de Processos Comunicacionais Ana Luísa Zaniboni Gomes, do Núcleo de rádio da Oboré

Experiência-jornal no ensino fundamental

Poesia - Renata Pallottini

Serviços - Vila Brasileira: um programa para protagonistas juvenis

Videografia - O desenho animado em sala de aula

Boletim bibliográfico - telenovela; comunicação e educação; endereços úteis na internet.

Comunicação, educação e tecnologia: interação

Número $1-2005$

(Maria Aparecida Baccega)

Após pausa nas publicações, a revista volta reafirmando seu compromisso com as premissas do primeiro número e reforçando o papel do educador e da escola na formação de cidadãos em um mundo editado pelos meios. A apresentação escrita por Baccega reapresenta os compromissos da revista e sua proposta editorial, que se funda nos avanços do campo comunicaçãoleducação. Destaca o objetivo de colaborar com a formação do leitor crítico, proporcionando-lhe condições para a compreensão dos mecanismos utilizados pelos meios de comunicação para a edição ou enquadramento do mundo. Reflete ainda sobre as interações entre comunicação, educação e tecnologia, destacando a necessidade de reconfiguração $e$ redimensionamento da escola dentro desta nova realidade.

Entre os temas tratados pela edição, estão:

Artigos nacionais - Jogos na web e ensino da história da arte (relações da arte com a internet); Interação e práticas sociais (co-produção); As múltiplas imagens do

cientista no cinema; Internet: um novo paradigma de informação e comunicação.

Artigos internacionais - A comunicação como conhecimento

Entrevista - A infoera transformando as relações sociais, com João Antonio Zuffo

Crítica - livro Mídia Radical (Estratégias de resistência à mídia hegemônica)

Depoimento - Cristina Coghi - reportagens feitas para a Rádio CBN sobre a Casa de Detenção de São Paulo

Experiência-Câmera e vídeo na escola: quem conta o que sobre quem?

Poesia - Carlos Drummond de Andrade

Serviços - NCE - A trajetória de um núcleo de pesquisa da USP

Videografia-História e literatura através do cinema

Boletim bibliográfico - telenovela; comunicação e educação; endereços úteis na internet. 
Comunicação e cultura: a construção de significados

Número $2-2005$

(Maria Aparecida Baccega)

Neste artigo, Baccega destaca que os meios de comunicação são feitos pelos homens e para os homens - devendo, portanto, serem dimensionados criticamente e sem submissão, sem que sejam considerados causas dos males da sociedade moderna. Para tanto, mostra a comunicação como diálogo, processo de inter-relação, troca e persuasão - sendo as informações, relatos e conhecimentos adquiridos sempre a partir de fatos narrados e descritos, tendo como base fundamental a linguagem verbal.

Fazem parte da edição:

Artigos nacionais - O cinema e a formação docente: um diálogo sobre as questões de gênero; Audioaula: o som como suporte pedagógico em sala de aula; Literatura na televisão: história, memória e biografia.

Artigos internacionais - Memória cotidiana e comunicação

Entrevista - Heródoto Barbeiro

Crítica - Da virtude à estratégia: os conflitos morais em A Grande Família

Depoimento - Tatiana Belinky

Experiência-Temas transversais para professores de Ciências

Poesia - Paulo Leminski

Serviços - O jornalismo de espírito público não pode ser "chapa-branca"

Videografia - Interdisciplinaridade nas possibilidades de leitura do filme Abril Despedaçado

Boletim bibliográfico - telenovela; comunicação e educação; endereços úteis na internet.

Número 3 - 2005

\section{Dez anos a serviço da construção do campo comunicação/educação}

(Maria Aparecida Baccega)

A edição, comemorativa de uma década de existência da revista, recupera sua proposta editorial e os pressupostos firmados sobre o campo comunicação/educação, de 1994. O resgate histórico da revista fica por conta da mesa-redonda promovida com os professores que contribuíram para sua criação, falando sobre a resistência e amadurecimento da experiência editorial do curso Gestão da Comunicação. Outros temas tratados na edição são as possibilidades de aprendizagem através do uso do cinema em atividades didáticas; e as tensões e soluções na incorporação das tecnologias da informação pela sociedade. Fernando Scavone dá depoimento sobre fotografia e descobre-se a importância de contar histórias e parábolas. $O$ encontro entre a formalidade da escola e a informalidade dos meios de comunicação proporciona uma educação mais inclusiva.

A partir desse número, a Apresentação passa a ser escrita alternadamente pelos professores especialistas do curso.

Fazem parte dos temas tratados na edição:

Artigos Nacionais - Pedagogia de Humberto Mauro: a natureza em Azulão $e$ O João de Barro; Tecnologia e sociedade: entre os paradoxos e os sentidos possíveis; Para começar um projeto de pesquisa; reflexão sobre meios e sobre fins.

Artigos Internacionais - uma revisão dos efeitos do storytelling nas tradições religiosas.

Entrevista - Dez anos de Comunicação \& Educação (Mesa-redonda especial)

Crítica - As Invasões Bárbaras e Adeus, Lênin! A (des)construção do sonho no cinema atual

Depoimento - Fernando Scavone

Experiência - divulgação científica sob a ótica das crianças de Peirópolis

Poesia - Vladmir Maiakovski

Serviços - principais serviços de Comunicação \& Educação

Videografia - Tempos e linguagens. Representações e inter-relações

Boletim bibliográfico - telenovela; comunicação e educação; endereços úteis na internet. 


\section{A linguagem entre a comunicação e educação}

(Adilson Citelli)

Neste texto, Citelli discute o desafio, posto à escola, de se trabalhar num universo marcado pelas linguagens complexas dos meios de comunicação e pelos novos modos de ver, sentir e compreender trazidos pelos estudantes que nasceram e cresceram tendo os meios ao seu redor. De acordo com o autor, este contexto tem motivado a promoção de pesquisas, reflexões e novas práticas por parte de comunicadores e educadores - que deram origem ao conceito de ecossistema comunicativo. Mais do que desenhar novos modelos educativos, é preciso, igualmente, ligar este cenário, também, às novas características dos instrumentos de produção $e$ das forças produtivas, assim como às estratégias organizadoras do capital no mundo contemporâneo.

A partir deste número, a revista passa a contar também com uma seção de artigos escritos por alunos do curso de Gestão a partir de suas pesquisas.

Fazem parte da edição:

Artigos nacionais - O cinema e a formação docente: um diálogo sobre as questões de gênero; Audioaula: o som como suporte pedagógico em sala de aula; Literatura na televisão: história, memória e biografia.

Artigos internacionais - configurações discursivas e reiteração dos sentidos; jornal na sala de aula, com atenção para a construção e análise de manchetes e seus elementos publicitários/persuasivos; televisão e a prática do zapping: interatividade com a audiência; conceito de infância registrado em textos da literatura infantil.

Artigos internacionais - constituição de certos mitos no contexto cultural asiático a partir do filme Nenhum a menos (1999), tendo por ambiente uma escola

Gestão - mito fundador da cidade de Guarulhos como tema para o projeto de intervenção no arquivo histórico da cidade

Entrevista - Palavra Cantada (grupo de música infanto-juvenil)

Crítica - como a dinâmica midiática, de um ponto de vista formal e no modo como agencia seus conteúdos, interage e interfere na produção imaginária do jovem e do juvenil

Depoimento - Mirella Martinelli, montadora de filmes brasileiros

Experiência-projeto educomunicativo em escola pública do ensino fundamental

Poesia-Cecília Meireles

Serviços - Casa das Rosas - Espaço Haroldo de Campos de Poesia e Literatura

Videografia - filme 11 de setembro. Onze minutos, nove segundos e uma imagem

Boletim Bibliográfico -telenovela brasileira; comunicação e educação

Endereços úteis na internet

\section{Educação, telenovela e crítica}

Número $2-2006$

(Maria de Lourdes Motter)

Neste texto, Motter questiona os fatores capazes de justificar a omissão da escola com relação ao gênero telenovela - parte do dia-a-dia não apenas de expressiva parcela da população brasileira, mas que atinge, indiretamente, todos os outros segmentos da sociedade, por meio de seus mecanismos de repercussão. A autora observa que, no trabalho ligado a comunicação e cultura, ignorar o gênero equivale a fugir não de uma ficção sem nobreza para entrar no espaço da educação formal, mas desprezar um elemento significativo na constituição da própria realidade. A descoberta da telenovela como espaço educativo é um desafio a ser enfrentado pelos educadores através da análise e da crítica deste produto midiático.

Fazem parte da edição:

Artigos nacionais - A teoria do valor de Marx e a educação do gosto; Perfis: modos de inserção de jornais televisivos; Uma proposta para a leitura crítica dos videogames; Apropriações melodramáticas: o caso Pedrinho no Jornal Nacional e em Senhora do Destino. Artigo internacionais - $O$ estudo das formas comunicativas como disciplinas do corpo: o caso da fotografia huichol.

Gestão - A luta contra o desemprego: os portões de fogo da atualidade 
Entrevista - Elifas Andreato

Crítica - Uma propaganda exemplar do governo Lula

Depoimento - Marília Franco

Experiência - Educação a distância no curso de especialização lato sensu Gestão da Comunicação

Poesia - Manuel Bandeira

Serviços - Projeto Clicar, em funcionamento na Estação Ciência

Videografia - Narradores de Javé, de Eliane Caffé, e Um filme falado, de Manoel de Oliveira

Boletim Bibliográfico - telenovela brasileira; comunicação e educação

Endereços úteis na internet

Sociabilidade mediatizada

Número 3 - 2006

(Maria Cristina Castilho Costa)

A apresentação lembra o impacto dos meios de comunicação na vida das pessoas e a sociabilidade mediatizada como parte integrante - e sustentadora - de uma nova ordem social. Neste sentido, segundo a autora, a presente edição teria por objetivo propor práticas pedagógicas e educativas que aproximem as ciências e os meios de comunicação de massa dos agentes e situações que envolvam a educação, contribuindo, dessa forma, para que o leitor se torne também um militante do campo da comunicação e educação. Embora de contornos ainda imprecisos, este novo campo atravessa fronteiras e divisões, colocando em diálogo saberes, mídias e diferentes áreas do conhecimento.

Fazem parte da edição:

Artigos nacionais - Olhar hipertextual: uma perspectiva bakhtiniana da

inclusão de imagens na sala de aula; Televisão digital interativa: expectativas de uso cultural e educativo

Artigo internacionais - princípios de educação entre os Parintintim e sobre a comunicação nesse processo; revolução informática e a necessidade de a escola incluir em sua proposta os novos modelos epistemológicos engendrados pelos meios de comunicação - o computador, $e$ também os celulares e as câmeras digitais

Entrevista - Eugênio Bucci, presidente da Radiobrás - Empresa Brasileira de Radiodifusão, atualmente denominada Empresa Brasileira de Comunicação

Depoimento - Ivaldo Bertazzo

Gestão - Leituras ambientais na paisagem transformada; relato do projeto de levar poesia às estações de Metrô de São Paulo

Crítica - Comunicação e recepção

Experiência - jogos eletrônicos e internet reunindo cinco escolas de oitava série do Paraná e de Santa Catarina

Poesia - No caminho, com Maiakovski

Serviços - Museu da Língua Portuguesa

Boletim Bibliográfico - telenovela brasileira; comunicação e educação

Endereços úteis na internet

Comunicação e educação: um olhar para a diversidade

Número 1 - 2007

(Solange Martins Couceiro de Lima)

Nesta apresentação, Lima lembra a importância de se levar em conta a diversidade étnica e cultural da sociedade brasileira, dentro do conceito de Pluralidade Cultural - tema, ainda muitas vezes, alvo de preconceito e discriminação. Discorre sobre como a LDO de 1996, os PCNs e as Diretrizes Curriculares Nacionais abriram caminho para o atendimento específico dos afro-descendentes com a aprovação da Lei 10.639, que institui as Diretrizes Curriculares Nacionais para Educação das Relações Étnico-Raciais e para o Ensino de História e Cultura Afro-Brasileira e Africana. Alerta, porém, para a necessidade do preparo de professores, educadores e dirigentes de escola para o cumprimento dessa tarefa, citando, nesse sentido, 
ações que vinculam a comunicação e a educação protagonizadas pelo NCE e seus pesquisadores.

Fazem parte da edição:

Artigos nacionais - As histórias em quadrinhos para a formação de leitores ecléticos: algumas reflexões com base em depoimentos universitários; A utopia brasileira da mídia cidadã ; A mediação tecnológica nos espaços educativos: uma perspectiva educomunicativa; Os espaços de leitura; Telenovela e realidade social: algumas possibilidades dialógicas.

Artigo internacionais - Comunicação e memória em tempos de repressão: uma análise interdisciplinar de Memórias do cárcere $e$ Primavera con una esquina rota.

Gestão - Contribuição dos cursos de especialização lato sensu para o desenvolvimento do campo da comunicação

Entrevista - Maria Luiza Marcílio, professora do Departamento de História da USP

Crítica - $O$ discurso hegemônico de Veja e a construção da imagem do pobre

Depoimento - cenógrafo Cyro Del Nero

Experiência - A televisão e o vídeo em sala de aula: uma experiência realizada com professores e alunos de história

Poesia-Martin Niemöller

Serviços - REDARTE-SP

Videografia - Camelos também choram $e$ Crianças invisíveis

Boletim Bibliográfico - telenovela brasileira; comunicação e educação

Endereços úteis na internet

Número $2-2007$

A ECA/USP e a Educomunicação: a consolidação de um conceito, em dezoito anos de trabalho

(Ismar de Oliveira Soares)

Soares lembra, aqui, a trajetória de dezoito anos de pesquisas, publicações, ensino e extensão cultural na interface entre comunicação e educação do Departamento de Comunicações e Artes da ECA/USP. A partir desta recapitulação, anuncia o encaminhamento para análise das autoridades da USP, por parte do CCA, do projeto inédito de Licenciatura em Educomunicação. $O$ autor ressalta a presença da revista Comunicação \& Educação nesta trajetória ao longo dos últimos doze anos, abrindo espaço de reflexão para pesquisadores e atores sociais da comunicação, ao lado de professores, em seu esforço de compreender a comunicação e levar suas tecnologias, linguagens e formas de gestão para o interior dos espaços e processos educativos.

Fazem parte do conteúdo da edição:

Artigos nacionais - teorias e práticas da recepção, o ensino da comunicação; uso pedagógico dos processos comunicativos; linguagens da comunicação.

Artigos internacionais - imigrantes e as minorias étnicas em Portugal

Gestão - comunicação como mediação nos museus de arte

Entrevista - Carlos Império Hamburger (Cao Hamburguer)

Crítica-publicidade nos livros didáticos do Ensino Médio

Depoimento - Renata Pallottini

Experiência - experiência pedagógica representada pela ferramenta wiki

Poesia-Bertold Brecht

Serviços - Instituto Arte na Escola

Videografia - Zuzu Angel (2006) e Lamarca (1994)

Boletim Bibliográfico - telenovela brasileira; comunicação e educação

Endereços úteis na internet 
Escola, linguagem e diversidade cultural nos contextos midiáticos

(Adilson Citelli)

Citelli analisa o tema da diversidade cultural, objeto de discussão em diversos âmbitos da vida social - e, particularmente, dentro dos meios de comunicação e da escola, tanto para posicioná-lo e estimulá-lo como para, simplesmente, esquecê-lo ou discriminá-lo por meio de arranjos discursivos (livros didáticos, programas de televisão, emissões de rádio e outros). $O$ artigo discute, principalmente, como as tensões culturais podem ser interpretadas nas linguagens que circundam as mídias e a escola.

Compõem o conteúdo da edição:

Artigos nacionais - produção literária para o público infantil, enfatizando o papel dos editores no período da República Velha; dissolução dos limites entre ficção e realidade nos discursos midiáticos; como a educação popular se faz à luz da globalização; intertextualidade, examinando singularidades da linguagem televisiva.

Artigo internacionais - mudanças pelas quais a comunicação vem passando, sintetizadas em três grandes eixos: as novas tecnologias da informação e da comunicação; o modelo políticoeconômico sustentado pelo neoliberalismo; e o paradigma da sociedade da informação e do conhecimento.

Gestão - as experiências culturais, artísticas e sociais do público que acessa o site Arte na Escola On-line e como melhorar o diálogo com essa ferramenta on-line.

Entrevista-Geneviève Jacquinot-Delaunay

Crítica-telenovela mexicana Rebelde

Depoimento - Amilton Godoy

Experiência - revista Viração

Poesia - João Cabral de Melo Neto

Serviços - Educação e pesquisa, da Faculdade de Educação da USP, e Leitura: Teoria \& prática, da Associação de Leitura do Brasil (ABL)

Boletim Bibliográfico - telenovela brasileira; comunicação e educação

Endereços úteis na internet

Sincretismos e os desafios da atualidade

(Maria Cristina Castilho Costa)

Nesta apresentação, Costa discorre sobre como o desenvolvimento dos meios de comunicação $e$, conseqüentemente, das ciências da comunicação, levaram os estudiosos a optar por um conceito mais imaterial e abstrato de cultura. Ao mesmo tempo, o desenvolvimento da indústria cultural em nível global, submetendo as diferentes culturas a um processo intenso de integração e homogeneização, intensificou o estabelecimento de uma cultura tecnológica. Desta forma, a educação, principal mecanismo social de elaboração e transmissão da cultura, teve que se dirigir por novos parâmetros pedagógicos, fazendo uso de novas linguagens para difundir a cultura do nosso tempo.

Compõem o conteúdo da edição:

Artigos nacionais - diálogo entre educação e cultura contemporânea relacionada ao videoclipe do grupo de rock Pearl Jam, Do the Evolution; importância das metáforas no aprendizado das ciências contábeis; a sinergia existente entre os diferentes meios de comunicação na promoção da telenovela, com foco nas sinopses publicadas nos jornais.

Artigo internacionais - Dominique Morizot, que aborda a capacidade da linguagem verbal em revelar competências e performances dos falantes.

Gestão - melhor aproveitamento da comunicação no aperfeiçoamento da relação entre gestores, usuários e comunidade nos Centros Educacionais Unificados (CEUs).

Entrevista - Jorge Huergo, diretor do Centro de Comunicação e Educação da Universidade Nacional de La Plata

Crítica - Show de Truman à luz de Mikhail Bakhtin e Michel de Certeau

Depoimento - Amilton Godoy

Experiência - Intencionalidade educativa em freqüência modulada: um desafio radiofônico 
Poesia - Solano Trindade, Ascenso Ferreira e Manuel Bandeira

Serviços - Memorial da América Latina

Videografia - Muito Além do Jardim

Boletim Bibliográfico - telenovela brasileira; comunicação e educação

Endereços úteis na internet

Número $2-2008$

\section{A importância da poesia e da imaginação}

(Maria Cristina Castilho Costa)

Costa relembra o passado de jovem leitora interessada em obras menosprezadas pela escola e o constrangimento que marcou sua adolescência por conta de ...E o vento levou, livro homônimo do filme consagrado pelo cinema. Dessa forma, analisa com bons olhos a mudança na forma como a educação vê o interesse dos alunos pelos meios de comunicação e pela literatura de variadas fontes. Enfatiza, também, a aproximação promovida por essa mudança entre alunos de professores.

Compõem o conteúdo da edição:

Artigos nacionais - relação realidade-notícia-imprensa; como os jornais britânicos The Guardian, The Independent $e$ The Times noticiaram os dois turnos do processo de reeleição de Lula para a Presidência da República; função social e educativa d'O Tico-tico; uso do audiovisual em sala de aula; teorias da recepção para estudar as relações entre o rural e o urbano mediado pela comunicação televisiva, a partir da recepção de estudantes de ensino médio quanto ao seriado Malhação.

Artigo internacionais - telenovela como narrativa cotidiana e coletiva construída dos dois lados da tela.

Gestão - Projeto de Comunicação constituidor da memória da universidade.

Entrevista - Yves Schwartz

Crítica - Arquivo Miroel Silveira

Depoimento - Paula Saldanha

Experiência - planejamento de professores de diversas disciplinas para o uso do game SimCity 4 em suas atividades didáticas

Poesia - centenário da morte de Machado de Assis

Serviços - Museu Goeldi

Videografia

Boletim Bibliográfico - telenovela brasileira; comunicação e educação

Endereços úteis na internet

Número $3-2008$

Comemorações em 2008: literatura, história, política, teatro, cinema e televisão. Tudo na escola!

(Roseli Fígaro)

Neste artigo, Fígaro assinada as diversas datas comemorativas importantes para as áreas de comunicação e educação no ano de 2008: os duzentos anos da imprensa no Brasil; os centenários da morte de Machado de Assis e do nascimento de Guimarães Rosa; os cinqüenta anos de Cinema Novo e o relançamento do álbum Chega de saudade, sobre a história da Bossa Nova. Porém, é também aniversário de maio de 1968, ou seja, momento de lembrar as lutas dos movimentos sociais, dos artistas e dos jovens brasileiros contra a Ditadura Militar e do AI-5. Temas que precisam, necessariamente, ser tratados com criatividade na escola.

Fazem parte da edição:

Artigos Nacionais - Comunicação e arte: o experimento sociológico de Brecht; Uma percepção do olhar: os três paradigmas da imagem à luz da semiótica peirceana; Jornalismo cidadão e independent Media Center; Quando o Educador do Ano é um educomunicador: o papel da USP na legitimação do conceito; Bicentenário da imprensa desafia sociedade a promover inclusão cognitiva.

Artigos Internacionais - Liberdade, identidade e criatividade na Música Popular Uruguaia;

Gestão da Comunicação - Propaganda, a arte de gerar descrédito 
Entrevista - A obrigatoriedade do ensino em Portugal: um desafio para a inclusão social

Crítica - Comunicação, recepção e consumo: suas inter-relações em Rebelde-RBD

Depoimento - Procedimentos para uma cena quase pronta: a vida de um mimo

Experiência - A literatura como patrimônio

Poesia - O silêncio em quatro interpretações

Serviços - O Museu Histórico da Imigração Japonesa no Brasil

Videografia - Mazzaropi e Lobato: Jeca Tatu ainda dá umas boas horas de conversa e pesquisa

Boletim Bibliográfico - telenovela brasileira; comunicação e educação

Endereços úteis na internet

Comunicação e educação: passagens e deslocamentos

Número $1-2009$ (Adilson Citelli)

Em sua parte inicial, Citelli procura refletir acerca dos mecanismos que inter-relacionam comunicação, educação e cotidiano. Para tanto, evoca os conceitos de não-lugar, deslocamento e resíduo, mostrando-os como instâncias que contribuem para melhor entender determinados processos de complementaridade, oposição e tensão colocados entre as salas de aula, os media e o saber comum.

Fazem parte da edição:

Artigos Nacionais - Reflexões sobre a dimensão social da música entre os jovens; Arte de Joseph Beuys: pedagogia e hipermídia; Universo feminino e trabalho; Construindo um novo espaço imaginário da publicidade na virada do século; Imagens constituintes: um exercício de análise de (contra)discurso.

Artigos Internacionais - O Grupo e a revista científica Comunicar: 15 anos pela e para a Educomunicação na Espanha

Gestão da Comunicação - A comunicação como via de inclusão social nos museus

Entrevista - Maria Cristina Castilho Costa

Crítica - $O$ inovador lançamento de In rainbows: contribuição para o debate sobre direitos autorais na cena digital

Depoimento - 62 anos de inclusão do deficiente visual (Dorina Nowill)

Experiência - Memórias de infância: possibilidades e vivências no processo criativo docente (Vanessa Freitag)

Poesia - O cotidiano revelado na poesia de Adélia Prado

Serviços - Projeto Escola no Cinema $e$ Clube do Professor

Videografia - Fahrenheit 451 e Escritores da Liberdade: uma discussão sobre leitura, escrita, imaginação, resistência e liberdade

Boletim Bibliográfico - telenovela brasileira; comunicação e educação

Endereços úteis na internet

Intramuros e extramuros: a aventura do conhecimento!

Número $2-2009$

(Roseli Fígaro)

Neste artigo, Figaro reflete sobre a pouca importância dada pelas escolas tanto ao poder da língua como a sua forma de conteúdo e de expressão das relações sociais - tendo como exemplo o filme francês Entre os muros da escola. De acordo com a autora, não compreender o papel da língua leva a definir a comunicação como transmissão de informação, desqualificando o processo de interação entre sujeitos na construção de sentidos. A mesma análise se aplica ao filme Quem quer ser um milionário?, também ótimo exemplo para o estudo da recepção da comunicação e fonte de conhecimento para professores e alunos.

Fazem parte da edição:

Artigos Nacionais - Organizadores da cultura: delimitação e formação; Novas tecnologias da comunicação: tempos e materialidade da escola pública; Comunicação e educação: atualização da inteligência coletiva em salas de aula; Traduções poéticas: o Romance d'A 
Pedra do Reino e o Príncipe do Sangue do Vai-e-Volta e a microssérie televisiva; Direitos humanos, cidadania e liberdade de expressão

Artigos Internacionais - Kapuscinski: guia para uma análise crítica das notícias sobre conflitos internacionais

Gestão da Comunicação - Encartes especiais: a gestão do conflito entre publicidade e

produção gráfica

Entrevista-SESC-SP: educação permanente, diversão garantida

Crítica - A tecnologia em favor da ficcionalização da violência, ou como tornar a violência

atraente

Depoimento - Um professor de Matemática na ECA

Experiência - Site wiki em sala de aula: uma experiência com hipertextualidade

Poesia-Mario Quintana

Serviços - Museu do Homem do Nordeste

Videografia - Lavoura Arcaica: palavras e imagens bordadas no tecido invisível do tempo

Boletim Bibliográfico - telenovela brasileira; comunicação e educação

Endereços úteis na internet

Número 3 - 2009

A contribuição da revista Comunicação \& Educação para a criação da Licenciatura em Educomunicação

(Ismar de Oliveira Soares)

A apresentação escrita por Soares classifica os artigos da presente edição da revista de acordo com as áreas de intervenção do campo da Educomunicação, buscando demonstrar a coerência do trabalho desenvolvido ao longo dos últimos quinze anos pelos editores e, de outro lado, pelo Departamento de Comunicações e Artes da USP. O artigo traz também a notícia da aprovação, em novembro de 2009, do Curso de Licenciatura em Educomunicação - reforçando o papel da revista como uma das mais utilizadas como referencial acadêmico no campo da comunicação, oferecendo contribuição decisiva para a proposta de formação de um profissional que será, simultaneamente, professor de comunicação e gestor de processos comunicacionais em espaços educativos.

Fazem parte da edição:

Artigos Nacionais - Comunicação/educação e a construção de nova variável histórica; A contribuição do cinema para a memória da ditadura brasileira; A função social da minissérie Grande Sertão: Veredas na construção de um sentido identitário de nação; Piolin e Arrelia: entre o popular, o erudito e o massivo; Futebol, poesia e drama: o espetáculo

Artigos Internacionais - O seminário, escola dos pobres, em Manhã submersa (1953)

Entrevista - Brincante: o encontro do popular e do erudito a serviço da cultura e da educação

Crítica - Espacialidades, consumo e trabalho pelos olhos de Mr. Hulot: uma análise de Playtime, de Jacques Tati

Depoimento - Fanny Abramovich

Experiência - A comunicação a serviço da cidadania e identidade de adolescentes

Poesia - A poesia de Manuel de Barros: entre o regional e o universal

Serviços - Museu do Futebol: o Brasil com emoção, história e diversão

Videografia - Para além do exótico ou bélico: cinemas e histórias do país de Tagore e Jamal Malik

Boletim Bibliográfico - telenovela brasileira; comunicação e educação

Endereços úteis na internet

Dificuldades e prazeres de uma publicação

(Maria Cristina Castilho Costa)

Nesta apresentação, Costa comenta a produção da revista Comunicação \& Educação a partir de sua estrutura editorial complexa, evidenciando as especificidades de seção nessa área de inter-relação entre a comunicação e a educação. $O$ objetivo final da publicação é, sempre, chamar a atenção do leitor para o esforço de discussão e diálogo a respeito da mídia, cultura, 
educação, política e ação social. $O$ artigo anuncia, ainda, conquistas recentes, como classificação do periódico, pelo Portal de Revistas Univerciencia.org, como o mais acessado entre 21 revistas brasileiras de comunicação, numa expressiva liderança em visitas, acessos $e$ downloads.

Fazem parte da edição:

Artigos Nacionais - Pesquisa em andamento: professores e cultura digital; imagem e ciência; Uso revolucionário dos meios de comunicação ao longo da história; recepção midiática e processos de leitura em diferentes mídias; Brinquedos e identidade infantil.

Artigos Internacionais - mídia e educação na construção da identidade infantil (Portugal)

Gestão - Do trato cotidiano com os trabalhadores do Porto de Santos: análise do impacto das transformações ocorridas nestes últimos anos de neoliberalismo e privatização numa das mais importantes instituições de luta trabalhista.

Entrevista - Isabella Bruni, sobre diferenças na relação entre comunicação e educação entre Brasil e Itália

Crítica - O filme Traffic e a mitologia do automóvel

Depoimento - Sarau do Binho

Experiência - introdução à linguagem poética, feita a partir da teoria de Chklovski, importante nome do formalismo russo, em duas turmas de $8^{a}$ série do Ensino Fundamental

Poesia - Mário Faustino

Serviços-Museu Afrobrasil

Videografia-Cinema e Sertão

Boletim Bibliográfico - telenovela brasileira; comunicação e educação

Endereços úteis na internet

Número $2-2010$

\section{Ambiências comunicativas}

(Adilson Citelli)

Neste texto, Citelli evidencia como o termo comunicação parece cada vez mais dependente da existência de outra dimensão, onde informações, notícias e acontecimentos, aparentemente, teriam abandonado os fluxos interpessoais para viverem no e do universo impessoal $e$ informatizado. Esse processo, segundo o autor, pode gerar uma falsa impressão de verdade. $O$ excesso de visualidade e audição gerado pelos media ofereceria, assim, uma espécie de máscara, que terminaria por recobrir a própria idéia do fazer comunicativo. A apresentação, por fim, indica as várias dimensões em que se pode operar com o conceito de comunicação.

Fazem parte da edição:

Artigos Nacionais - Pesquisa em andamento: professores e cultura digital (parte 2); O espaço da mídia na escola; a noção de "duplo" discutida a partir do filme A bela Junie; leitura relacionada ao papel da escola; A comunicação nos empreendimentos econômicos solidários.

Artigos Internacionais - Comunicação ambiental para o século XXI

Gestão - Biblioteca Mário de Andrade

Entrevista - Francisco Whitaker

Crítica - estratégias de narrativa ficcional e do gênero melodramático no jornalismo

Depoimento - Flávio Pimenta, da Associação Meninos do Morumbi

Experiência - projetos experimentais desenvolvidos como práticas pedagógicas com alunos de graduação nos cursos de comunicação

Poesia - O operário em construção, de Vinicius de Moraes, e Construção, de Chico Buarque de Hollanda

Serviços - Centro de Pesquisa de História Natural e Arqueologia do Maranhão

Videografia - Diários de motocicleta, de Walter Salles; $e$ Che: Part One $e$ Che: Part Two (A guerrilha), de Steven Soderbergh, todos enfocando aspectos da trajetória vivencial e política de Che Guevara.

Boletim Bibliográfico - telenovela brasileira; comunicação e educação

Endereços úteis na internet

Número 3 - 2010 
Comunicação/educação: campo de ressignificação das tecnologias de comunicação (Roseli Fígaro)

Neste artigo, Figaro trata da importância da compreensão do uso das tecnologias de informação e comunicação no espaço educacional, partindo do princípio de que tais tecnologias são produtos de uma lógica voltada para o mercado cultural, com linguagem e uso bem direcionados - e que, ao serem introduzidas na escola, passam necessariamente por um processo de ressignificação. Dependendo do projeto educacional da instituição, os educadores terão a tarefa de compreender a complexidade de tais técnicas e linguagens para, utilizando-se delas e reorientá-las para a formação de novos cidadãos.

Fazem parte da edição:

Artigos Nacionais - Estudos de recepção para entender os usos da mídia na escola; Cinema de poesia: os germens poéticos que fecundam Lavoura arcaica; Corpo e tecnologia na sala de aula: estudos contemporâneos; Fotografia e fotoescultura: significação, arte e educação; Educomunicação e terceiro entorno: diálogos com Galimberti, Echeverría e Martín-Barbero.

Artigos Internacionais - Fotografia criativa para as crianças: a alfabetização audiovisual através da fotografia.

Gestão - Observatório da imprensa na internet: uma leitura crítica da mídia brasileira.

Entrevista - André Barbosa Filho

Crítica-Consumo, identidade e publicidade: uma relação a ser (re)pensada

Depoimento - Jovem escritor de gerações (Pedro Bandeira)

Experiência - A interatividade na educação a distância: o papel central da interatividade nos processos de ensino-aprendizagem na EAD

Poesia - Comunicação poética: São Paulo sob quatro olhares

Serviços - Museu Histórico Nacional

Videografia - Uma novela de Rosa: um auto de Suassuna e um encontro entre o erudito, o popular e o massivo

Boletim Bibliográfico - telenovela brasileira; comunicação e educação

Número 1 - 2011

A Licenciatura em Educomunicação e as novas diretrizes para o Ensino Fundamental (Ismar de Oliveira Soares)

Neste artigo, Soares fala sobre o início das atividades de dois cursos de graduação voltados à Educomunicação - a Universidade de São Paulo, com sua licenciatura, e a Universidade Federal de Campina Grande-PB, com o curso de bacharelado. O lançamento dos programas, simultaneamente à publicação, pelo Conselho Nacional de Educação, das Diretrizes Curriculares Nacionais para o Ensino Fundamental de Nove Anos, abre um novo campo de atuação ao autorizar a escola a compartilhar, com especialistas de outras áreas, o trabalho ligado às relações entre a mídia e a educação.

Fazem parte da edição:

Artigos Nacionais - Um dispositivo analítico para a investigação da leitura de textos de divulgação científica; Ensino de ética jornalística: pedagogias e metodologias de professores; $O$ "fundo do poço" e as motivações da censura; A comunicação, a recepção e o consumo enquanto práticas culturais: um novo olhar; Música e disco no Brasil: a trajetória do Grupo Eldorado.

Artigos Internacionais - Cultura jovem e identidade.

Gestão - CETVN - Centro de Estudos de Telenovela: "Fale Conosco!". A Gestão da Comunicação on-line.

Entrevista - Lúcia Araújo

Crítica - O discurso da ironia e o consumo do grotesco na publicidade

Depoimento - Raquel Trindade, ativista cultural do movimento negro

Experiência - O cinema a serviço da educação: a experiência das escolas de ensino básico e secundário no Algarve

Poesia-Orides Fontela

Videografia - Bicho de Sete Cabeças

Boletim Bibliográfico - telenovela brasileira; comunicação e educação 
Número $2-2011$

Educar: ver cores, cinzas e sombras e diferentes maneiras de viver essas diferenças

(Maria Cristina Castilho Costa)

O texto de Costa trata da educação - a partir do capítulo $\mathrm{O}$ caso do pintor daltônico, publicado no livro Um antropólogo em Marte, do neurologista Oliver Sacks - como um fenômeno amplo e complexo, ao mesmo tempo institucional e não institucional, formal e não formal, que se processa durante toda a vida e que nos faz cada vez mais flexiveis e humanos, capazes de desenvolvermos formas peculiares de enxergarmos o mundo, nele nos colocarmos e com ele nos relacionarmos. A comunicação nos oferece recursos para atuarmos nesse processo. A partir desta reflexão, traça os temas presentes na edição:

Artigos Nacionais - desenvolvimento de estudos interdisciplinares (economia política da comunicação); linguagem da oralidade no circo; Os discursos da Rádio Rural de Natal nos anos 1960: um capítulo da relação comunicação/educação no Brasil; Street papers: instrumento de interação social; Relacionamentos amorosos nas telenovelas: consumo e retrato da sociedade do século XXI.

Artigos Internacionais - Os estudantes: dentro e fora da escola; A contribuição dos meios públicos e alternativos para a democracia participativa.

Entrevista - Fernando Rosseti

Crítica - Clô: um personagem da sociedade de consumo (telenovela)

Depoimento - Francisco Brennand, escultor e artista plástico

Experiência - Quando a intenção de comunicar supera 140 caracteres

Poesia-Cacaso

Videografia-Eu e meu guarda-chuva

Boletim Bibliográfico - telenovela brasileira; comunicação e educação.

\subsection{Interpretação dos dados}

\subsubsection{Observação Direta}

Por meio da observação direta realizada ao longo do trabalho profissional com a revista, e também da pesquisa acadêmica, algumas questões relevantes a respeito de sua trajetória puderam ser levantadas. A observação do material proporcionou, especialmente, a reflexão a respeito dos temas e desafios no campo de interface entre comunicação e educação, previstos para os anos seguintes por especialistas e estudiosos - bem como a oportunidade de verificar a concretização ou não das expectativas desses autores a respeito de questões como as novas tecnologias, a globalização versus a afirmação de identidades e o reconhecimento do campo da comunicação e educação junto à sociedade. Tais impressões foram comprovadas e aprofundadas pela análise de conteúdo feita pelos instrumentos descritos a seguir. 


\subsubsection{Pesquisa bibliográfica}

A pesquisa realizada dentro da Escola de Comunicações e Artes, e também junto a obras relacionadas à interface entre comunicação e educação, foi importante para traçar um panorama da evolução e do reconhecimento deste campo dentro do meio acadêmico - demonstrando, ainda seu avanço em direção tanto à construção de políticas públicas quanto de iniciativas criadas e geridas por organizações da sociedade civil. O perfil dos autores participantes da revista (detalhado mais à frente) é um indicador importante das tendências discutidas a cada edição, e que marcaram também a discussão geral no campo.

A pesquisa bibliográfica ofereceu bases, também, para a construção das referências teóricas deste trabalho, já detalhadas em capítulo específico.

\subsubsection{Entrevistas em profundidade}

Por meio das entrevistas em profundidade, foi possível observar a visão particular de cada professor a respeito da criação e evolução da revista - visão esta que se confunde, por vezes (e com resultados positivos para esta pesquisa) com o próprio momento histórico pelo qual passavam o Brasil e a Universidade. As impressões particulares a respeito da publicação, seus propósitos e seu papel no cenário acadêmico também foram importantes para fazer compreender características específicas de sua elaboração - como a escolha das seções, a importância de sua criação para a discussão sobre comunicação e educação e, também, a relação da mesma com setores não acadêmicos, mas igualmente fornecedores de parâmetros importantes para a construção do campo. As reflexões a respeito dos principais pontos discutidos nas entrevistas são expressas ao longo do próprio trabalho.

\subsubsection{Análise de Enquadramento}

A análise de enquadramento, realizada tanto por meio do conteúdo das seções Apresentação como das palavras-chave dos artigos de todas as edições da revista, demonstrou as principais preocupações expressas pelos autores e colaboradores em relação à discussão da interface entre comunicação e educação. De modo geral, o fio 
condutor das reflexões de cada edição manteve sua convergência com os temas propostos nesta seção inicial, expressos por meio dos assuntos abordados nos artigos.

Entre esses temas, por exemplo, esteve o uso dos novos recursos tecnológicos não como atividade-fim da aprendizagem, mas como instrumentos de auxílio à relação educador versus aluno - ajudando-os a ampliar sua visão a respeito do conhecimento construído conjuntamente. Essa preocupação pode ser comprovada por meio dos termos e conceitos discutidos pelos autores, e destacados (em negrito) tanto durante a descrição dos dados da análise de enquadramento como pela análise do perfil dos mesmos.

A evolução da abordagem da relação entre comunicação e educação, por sua vez, pode ser verificada não só diretamente por meio da discussão desenvolvida, mas também pelas próprias questões abordadas nos artigos - que foram, gradativamente, ampliando o campo de discussão a respeito desta interface para além do espaço da educação formal e abrangendo ambientes educativos de toda a comunidade, assim como buscando mostrar o processo de sua legitimação por meio de projetos, ações e da consolidação de políticas públicas. Nota-se ainda que, ao longo das edições, a revista buscou sempre reforçar a ligação dos assuntos tratados academicamente com o cotidiano.

Para proporcionar uma análise mais detalhada do processo de escolha dos temas ao longo da existência da publicação, o material analisado foi dividido em duas fases: a inicial é representada pelos anos de 1994 a 2003, que caracterizam a primeira década da revista, sob coordenação da professora Maria Aparecida Baccega - que estabelecia e consolidava a linha de um novo produto editorial, bem como os principais temas que permeavam o debate dos profissionais e estudiosos das duas áreas.

A segunda fase, de 2004 a 2011, retrata a década mais recente de existência da publicação, quando podemos notar, por exemplo, a incidência de temas ligados à maior difusão das novas mídias entre estudantes e professores - além de mudanças internas na própria equipe da revista, que influiriam em sua organização editorial. Conduzida por dois Editores com formações e trajetórias diversas, essa pluralidade é trazida também para o perfil da publicação, especialmente no que se refere à pluralidade de ambientes educativos relatados e analisados em seus textos. 
O comparativo a seguir mostra os assuntos que surgem com maior frequência em cada grupo de edições analisadas. Para facilitar a observação das ocorrências, os temas descritos nas palavras-chave foram reunidos em grandes grupos, levando-se em conta critérios de afinidade e de incidência - significativa, também, para o entendimento do perfil da publicação (o tema Cinema, por exemplo, foi colocado em categoria separada de comunicação/mídia devido ao alto grau de ocorrência ao longo das edições, um indicativo do destaque dado à discussão da dramaturgia ligada a esse meio de comunicação).

As categorias utilizadas para a análise, portanto, são as seguintes:

Artes/Expressão: Acervo; Arte; Ator; Atriz; Autoestima; Charge; Criatividade; Cultura Brasileira; Dança; Encontro; Humor; Jogos; Literatura; Literatura infantojuvenil; Museu de Arte Contemporânea; Música; Poesia; Teatro; Voz.

Ciências sociais: Anos 60; Brasil; Carlos Lamarca; Cidadania; Cotidiano; Crianças; Cultura; Democracia; Ditadura Militar; Diversidade; Espacialidade; Ética; Futebol; Globalização; Hegemonia; História; Identidade; Igualdade; Juventude; Memória; Negro; Preconceito; São Paulo; Trabalho; Violência.

Cinema: Cinema; Cinema Nacional; Filme; O que é isso, companheiro?.

Comunicação e Educação: Comunicação e Educação; Educomunicação.

Comunicação/mídia: Audiência; Comunicação; Comunicação Comunitária; Comunicação e consumo; Crítica; Fotografia; Gestão da comunicação; Informação; Mediações; Meios de comunicação; Mídia; Produção; Programação; Recepção; Serviço; Tecnologia.

Educação: Aluno; Arte-educação; Autoestima; Biblioteca; Ciência; Conhecimento; Educação; Educação a distância; Educação para os meios; Ensino; Ensino de Português; Ensino Fundamental; Escola; Estação Ciência; Formação de professores; Interdisciplinar; Leitura; Livro; Matemática; Museu; Pesquisa; Português; Produção de textos; Professor; Projeto pedagógico; Sala de aula.

Jornalismo: Assessoria de imprensa; Imprensa; Jornal; Jornalismo; Reportagem .

Novas tecnologias: Ferramenta Wiki; Hipertexto; Informática; Interatividade; Internet; Novas tecnologias.

Políticas públicas: Lei de Diretrizes e Bases; TV Educativa; TV Escola. 
Publicidade: Benetton; Consumo; Outdoor; Publicidade.

Rádio: Participação e rádio; Radialista; Rádio; Radiodifusão.

Televisão: Rede Globo; Telenovela; Televisão; TV Cultura.

\section{Artigos Nacionais}

Por questões de organização do volume de artigos analisados e para facilitar a visualização das ocorrências mais frequentes, foram incluídos nos gráficos sobre esta seção os artigos com índice de ocorrência maior a duas vezes. Durante a primeira década de existência da revista, nota-se o forte destaque dados aos temas relacionados a educação - presente em mais da metade dos cerca de 100 artigos analisados. Outros temas que remetem a discussões conceituais, como cidadania, história, cultura ou jornalismo aparecem entre os mais citados e, aqui, agregados sob o título ciências sociais. Jornal, meios de comunicação, televisão e internet também aparecem, já se referindo ao tema das tecnologias na educação.

Nos primeiros tempos de existência da revista, ainda era preciso definir, junto aos leitores, a relação existente entre os campos da comunicação e da educação - e, talvez, especialmente junto aos profissionais da área de educação, mais distante da natureza própria da Escola de Comunicações e Artes - para, como segundo passo, discutir diretamente a interface entre eles. A comunicação, campo pretensamente mais familiar aos autores e leitores da revista, aparece abordada de forma mais discreta, ou por meio de seus desdobramentos temáticos (como no caso das palavras-chave Televisão e Jornalismo).

A revista se chama Comunicação e Educação porque trata de campos que devem formular teorias a respeito da produção de sentido. A produção de sentido tem um pé em cada um desses lugares - e continuo defendendo que o mais importante é ver a comunicação a partir da educação, e não o contrário. Compete a nós fazer com que as questões de comunicação e educação entrem na escola, ao invés de serem 
discutidas no recreio ou em outros lugares, porque elas são discutidas. $^{103}$

Embora apareça com menor ênfase nesta fase, o tema Televisão já demonstra, por sua vez, a importância dada à discussão dos efeitos desse meio de comunicação, assim como de seu potencial de influência junto aos processos educativos e de construção social. A recorrência deste assunto marca todas as edições da primeira década de existência da revista.

Já a presença de temas como cidadania, violência, ética e democracia (dentro de ciências sociais) mostram, já desde o início da história da publicação, a preocupação em se discutir as formas de reafirmação cidadã por meio dos espaços já assegurados para isso pelos sistemas político e social - assim como as formas de ampliação desses espaços por meio da própria ação de alunos, educadores e profissionais das áreas de comunicação e educação.

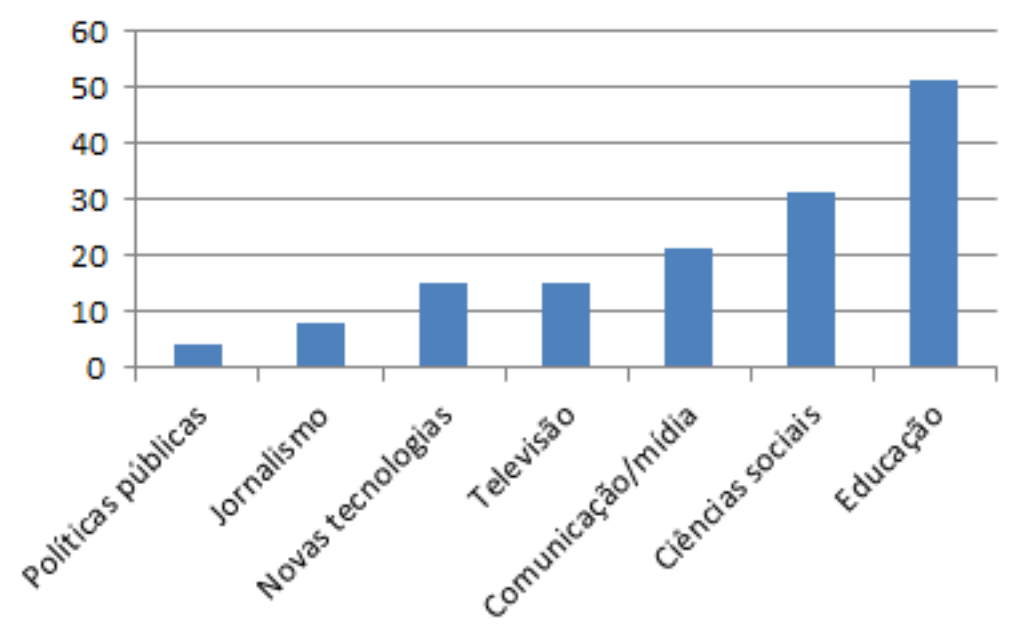

Ilustração 9. Áreas dos temas mais citados na seção Artigos Nacionais de Comunicação \& Educação entre os anos de 1994 e 2003.

${ }^{103}$ Entrevista concedida pela professora Maria Aparecida Baccega em 27.04.2012, em São Paulo/SP. 


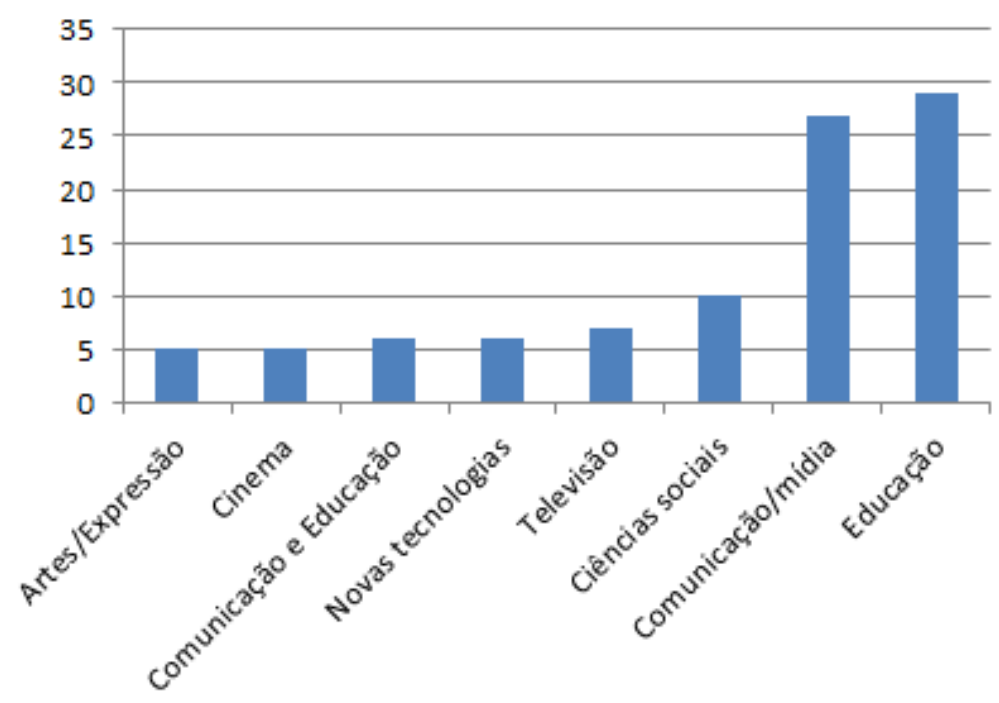

Ilustração 10. Principais temas abordados na seção Artigos Nacionais de Comunicação \& Educação entre os anos de 2004 e 2011.

Já na segunda década de atuação, a seção Artigos Nacionais registrou visível concentração do volume de textos sobre comunicação e educação. De forma geral, os artigos partiram de um desses dois temas para discutir assuntos específicos relacionados aos demais também registrados no gráfico, como cinema, teatro e televisão. Nota-se interesse especial em discutir os meios de expressão pelos quais se pode trabalhar com a comunicação na escola, enquanto o tema comunicação e educação, propriamente, ocupa lugar de interesse equivalente ao dos artigos de interesse mais específico - abrangendo também o termo Educomunicação, que entra na lista dos mais citados nesta segunda década. Citelli analisa os diversos momentos históricos retratados pela revista:

Nos anos 1960 e 1970, houve toda uma discussão com relação às tecnologias que estavam entrando na escola, por influências e também conceitos de educadores mais comportamentalistas que definiam isso tudo como Tecnologias da Educação. Dizia-se que era preciso levar as tecnologias para a educação. Esse vetor tecnicista, que é uma leitura muito comportamental e responsiva a demandas tecnológicas, cria uma ambiência que não se pergunta muito sobre o sentido, o lugar social, a natureza das coisas. Eu diria que essa é uma tendência que continua existindo - e que a revista é uma publicação que tenta, na medida do seu alcance, colocar sob cheque essa perspectiva. Se fizermos um 
levantamento desses anos da revista, veremos que mesmo os artigos voltados diretamente às tecnologias da educação são mais polêmicos, questionam mais esse tipo de coisa, transcendem a circunscrição meramente cooperativa e operacional. Esse é um debate permanente não só da educação, mas da sociedade - sobre os lugares sociais que os equipamentos ocupam e sobre a visão que se tem em relação aos dispositivos. ${ }^{104}$

A análise editorial deste conjunto de artigos nos faz perceber de forma mais detalhada, também, os principais pontos da agenda setting dos anos em que a revista foi editada - a menção a programas de televisão, personagens de telenovela ou do noticiário nos mostra a busca da revista em se conectar de forma permanente com a atualidade (ver assuntos abordados nas duas décadas na seção Anexos).

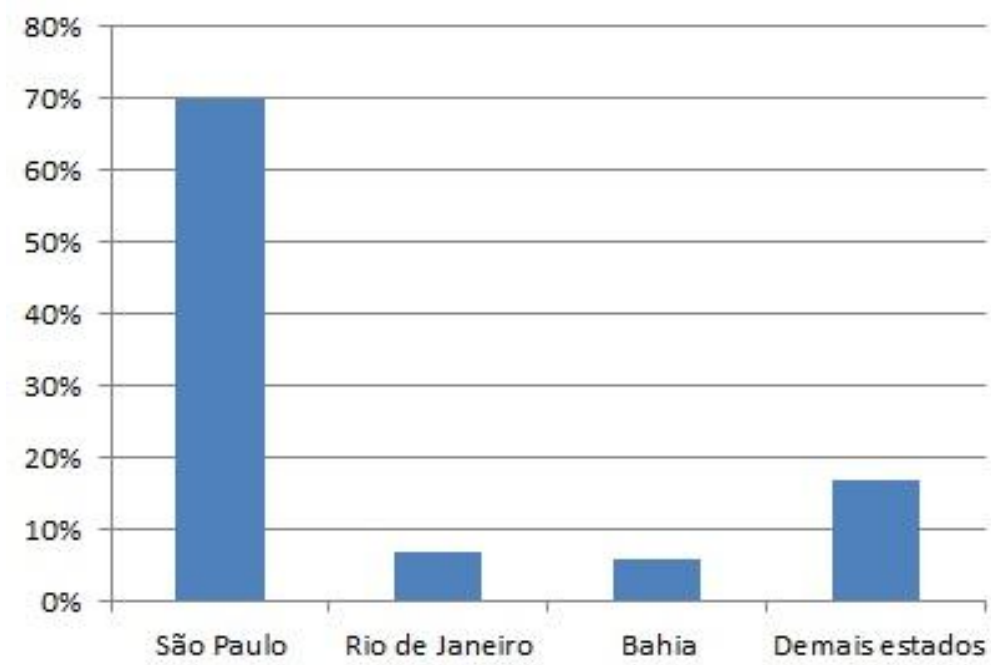

Ilustração 11. Procedência geográfica dos artigos publicados na seção Artigos Nacionais de Comunicação \& Educação

Tomando-se por base a procedência geográfica dos autores, a revista recebeu $70 \%$ de colaborações vindas do estado de São Paulo. O segundo estado a enviar mais colaborações é o Rio de Janeiro, com aproximadamente $7 \%$ dos textos, seguido do estado da Bahia, com uma média de 6\%. Os estados de Santa Catarina, Distrito Federal, Minas Gerais, Rio Grande do Sul, Paraná, Mato Grosso do Sul, Sergipe, Roraima, Pará, Pernambuco e Goiás também foram responsáveis por enviar contribuições.

${ }^{104}$ Entrevista concedida pelo prof. Adilson Citelli em 12.01.2012, em São Paulo/SP. 
A seguir, temos uma relação das ocorrências de autores que tiveram artigos publicados mais de uma vez durante os primeiros dez anos da revista, assim como um breve perfil de cada um deles à época da publicação de seus textos ${ }^{105}$ :

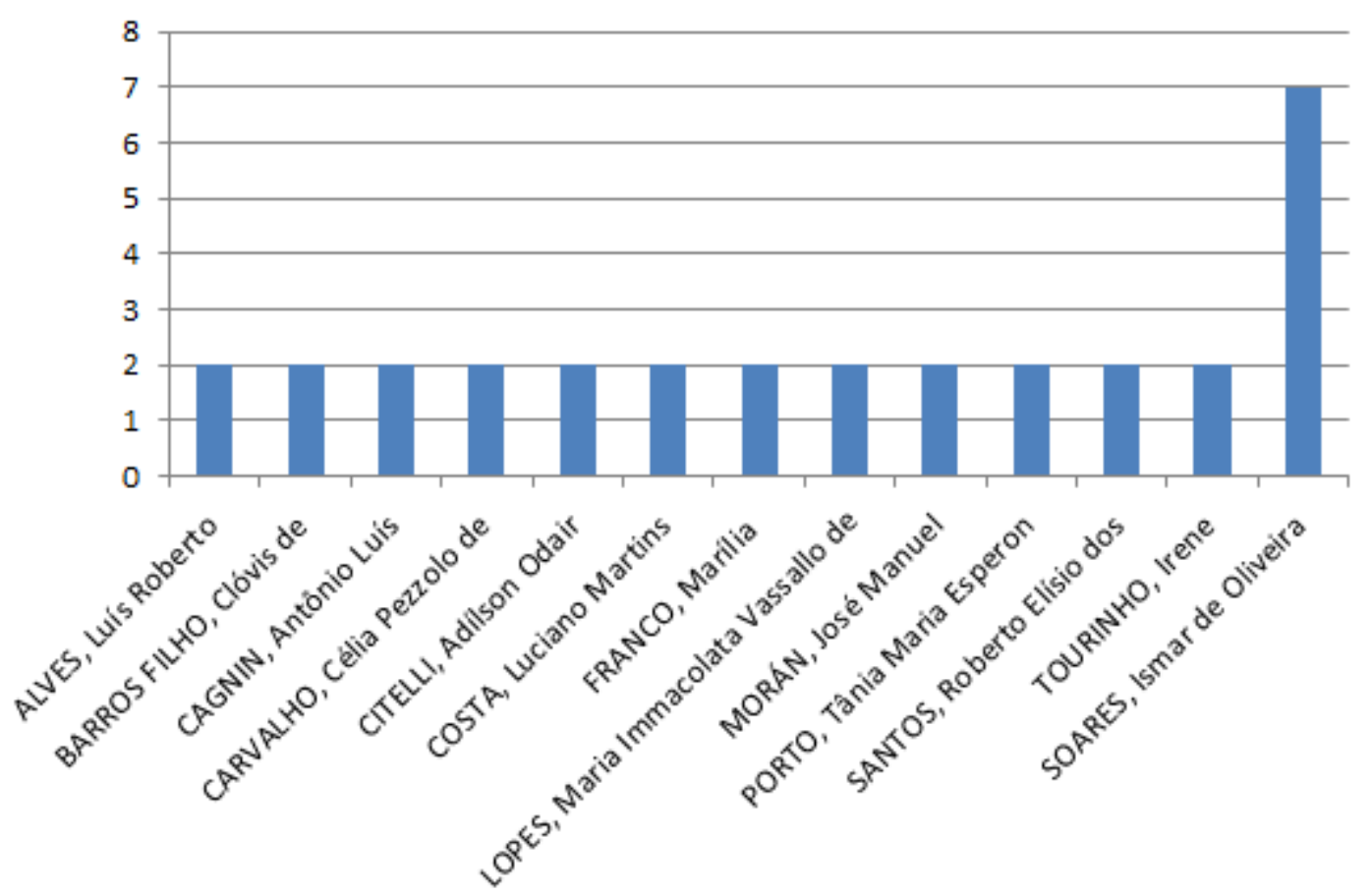

Ilustração 12. Principais autores que colaboraram com a seção Artigos Nacionais de Comunicação \& Educação entre os anos de 1994 e 2003.

ALVES, Luís Roberto - Professor e pesquisador da USP. Livre-Docente em Comunicação e Artes. Assessor de movimentos sociais. Ex-Secretário de Educação, Cultura e Esportes de São Bernardo do Campo/SP (1989-1992).

BARROS FILHO, Clóvis de - Professor de Metodologia e Ética do Curso de Jornalismo da Faculdade Cásper Líbero, São Paulo.

CAGNIN, Antônio Luís - Professor Doutor da do Departamento de Cinema, Rádio e Televisão da ECA/USP. Autor de Os Quadrinhos, editado pela Ática.

CARVALHo, Célia P. de - Professora Doutora do Departamento de Psicologia e Educação e do Laboratório de Ensino de Ciências da Faculdade de Filosofia, Ciências e Letras de Ribeirão Preto da USP.

CITELLI, Adílson Odair - Professor Doutor do Departamento de Comunicações e Artes da ECA/USP. Especialista em Comunicação e Educação.

\footnotetext{
${ }^{105}$ Mini-currículo dos autores disponível em http://www.eca.usp.br/comueduc/antigos/infogera/autor1.htm. Acesso em 01.07.2012.
} 
COSTA, Luciano Martins - Jornalista e escritor. Editor executivo do jornal O Estado de S. Paulo, responsável pela NetEstado.

FRANCO, Marília - Professora Doutora do Departamento de Cinema, Rádio e Televisão da Escola de Comunicações e Artes e Coordenadora Acadêmica da TV USP.

LOPES, Maria Immacolata Vassallo de Lopes - Professora Doutora do Departamento de Comunicações e Artes da ECA/USP e Presidente da Intercom Sociedade Brasileira de Estudos Interdisciplinares da Comunicação.

MORÁN, José Manuel - Doutor em Comunicação pela Universidade de São Paulo. Professor de Novas Tecnologias no Curso de Televisão da USP.

PORTO, Tânia Maria Esperon - Professora Doutora do curso de Mestrado em Educação da Faculdade de Educação da Universidade Federal de Pelotas - RS.

SANTOS, Roberto Elísio dos - Doutorando em Comunicação pela ECA/USP; professor da Faculdade de Comunicação Social do Instituto Metodista de Ensino Superior - São Bernardo do Campo; jornalista; autor do livro Introdução à Teoria da Comunicação.

SOARES, Ismar de Oliveira - Coordenador do Núcleo Comunicação e Educação do Departamento de Comunicações e Artes da ECA/USP. Vice-presidente para a América Latina do World Council for Media Education.

TOURINHO, Irene - Professora Titular da Faculdade de Artes Visuais da Universidade Federal de Goiás. Doutora em Educação Musical pela Universidade de Wisconsin - Madison, EUA.

Percebemos que, entre os autores participantes desta primeira fase, estão profissionais ligados às áreas de mídia - cinema, rádio, televisão e jornalismo -, artes e teorias da comunicação, com forte interesse na discussão da interface entre comunicação e educação. A observação revela que a discussão conceitual desta interface, nesse momento, é relacionada também a outros temas ligados a mídias $e$ expressão. 
Durante a segunda década de existência da revista, temos as seguintes participações mais frequentes:

BACCEGA, Maria Aparecida - Professora aposentada do Departamento de Comunicações e Artes da ECA/USP. Ex-coordenadora do curso de Pós-Graduação lato sensu Gestão de Processos Comunicacionais.

BRAGA, José Luiz - Professor titular em Ciências da Comunicação na Universidade do Vale do Rio dos Sinos (Unisinos).

CITELLI, Adílson Odair - Professor Doutor do Departamento de Comunicações e Artes da ECA/USP. Especialista em Comunicação e Educação.

COSTA, Maria Cristina Castilho - Professora Livre-Docente do Departamento de Comunicações e Artes da ECA/USP.

FREDERICO, Celso - Professor da Escola de Comunicações e Artes da Universidade de São Paulo. Bolsista do CNPq.

MELO, José Marques de - Titular da Cátedra UNESCO de Comunicação para o Desenvolvimento Regional - Universidade Metodista de São Paulo.

PIATTI, Deise Ellen - Mestranda em Letras - área de concentração em Linguagem e Sociedade da Unioeste -, linha de pesquisa em Linguagem Literária e Interfaces Sociais: Estudos Comparados pela Capes.

SILVA, Acir Dias da - Professor do Centro de Educação, Comunicação e Artes (CECA) da Universidade Estadual do Oeste do Paraná (Unioeste). Professor do Programa de Pós-graduação Stricto Sensu - Mestrado em Letras -, área de concentração em Linguagem e Sociedade da Unioeste. Pesquisador Associado do Laboratório de Estudos Audiovisuais (Olho), da Universidade Estadual de Campinas.

SOARES, Ismar de Oliveira - Coordenador do Núcleo Comunicação e Educação do Departamento de Comunicações e Artes da ECA/USP. Vice-presidente para a América Latina do World Council for Media Education.

VERGUEIRO, Waldomiro - Professor titular da Escola de Comunicações e Artes da Universidade de São Paulo - ECA/USP, onde é coordenador do Observatório de Histórias em Quadrinhos.

Nesta segunda fase, a presença de pesquisadores ligados diretamente à área de comunicação e educação ganha destaque, evidenciando a discussão teórica e acadêmica 
- e também a expansão do conceito para fora do Estado de São Paulo, como se pode notar pelo aumento da presença de pesquisadores de outros estados, tendência notada durante a primeira década e consolidada nesta segunda.
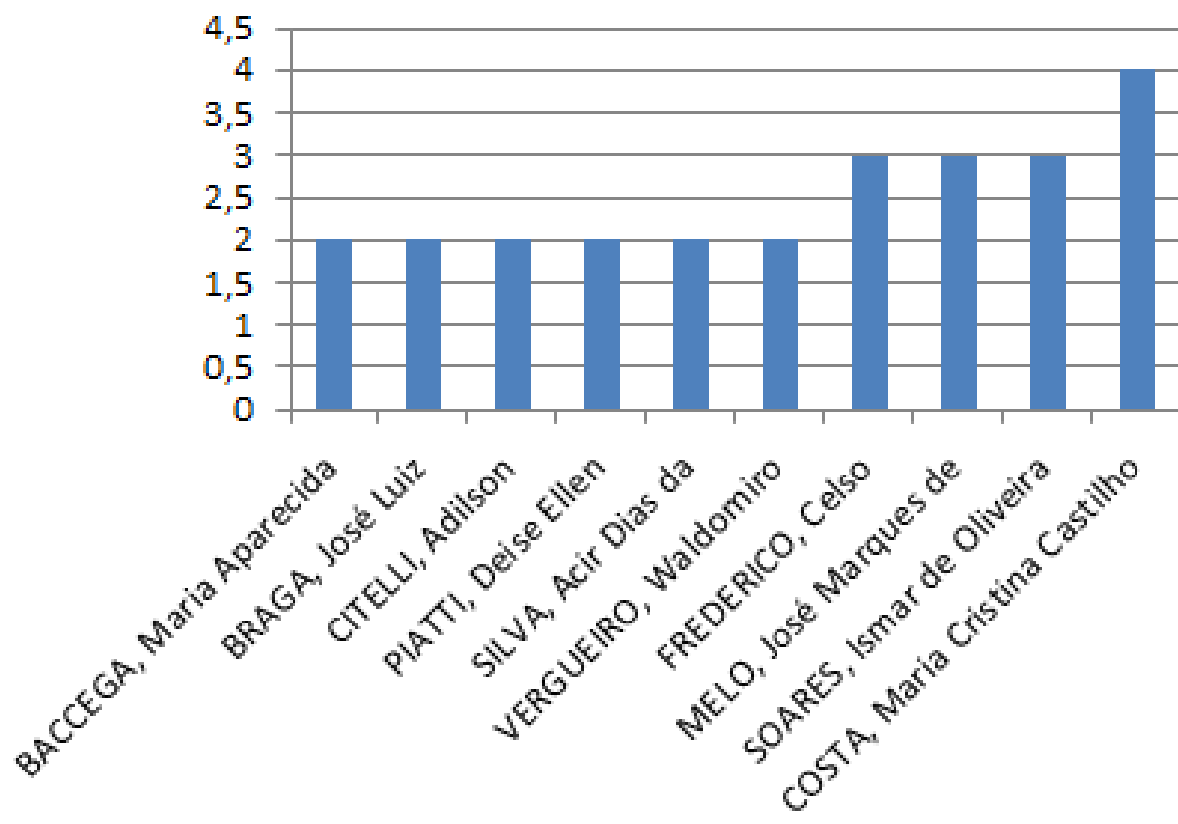

Ilustração 13. Principais autores que colaboraram com a seção Artigos Nacionais de Comunicação \& Educação entre os anos de 2004 e 2011.

\section{Artigos internacionais}

Durante a primeira década de existência da revista, o tema televisão segue ocupando lugar de destaque também na discussão internacional. Percebe-se, dessa forma, a preocupação global em lidar com esta mídia e seus efeitos, considerados determinantes na discussão sobre a formação pessoal do aluno.

Os temas tecnologia e globalização (dentro do campo maior aqui chamado de ciências sociais) também aparecem entre os mais abordados, mostrando o interesse da comunidade internacional em acompanhar as mudanças que já se anunciavam nos modelos comunicacionais para as próximas décadas. Assuntos como educação a distância, internet e educação para os meios (dentro de novas tecnologias) reforçam essa preocupação - embora ainda apareçam de forma mais discreta em relação a outros temas abordados no período. 


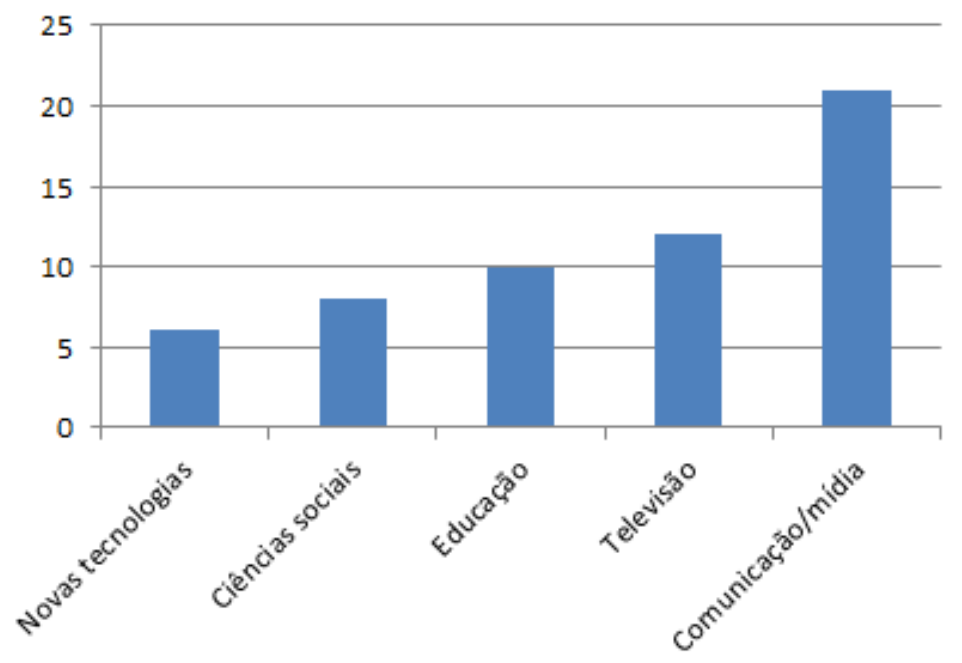

Ilustração 14. Principais temas abordados na seção Artigos Internacionais de Comunicação \& Educação entre os anos de 1994 e 2003.

$\mathrm{Na}$ segunda década de existência da revista, os temas comunicação e educação assumem o posto de mais abordados entre os artigos internacionais, dando base à discussão, nos mesmos textos, de outros assuntos especialmente voltados aos meios pelos quais são experienciados (televisão, radiodifusão, fotografia, jornalismo e outros). Nota-se uma pulverização conceitual nos assuntos abordados, ao contrário do ocorrido da primeira década, em que o tema televisão era uma preocupação destacada.

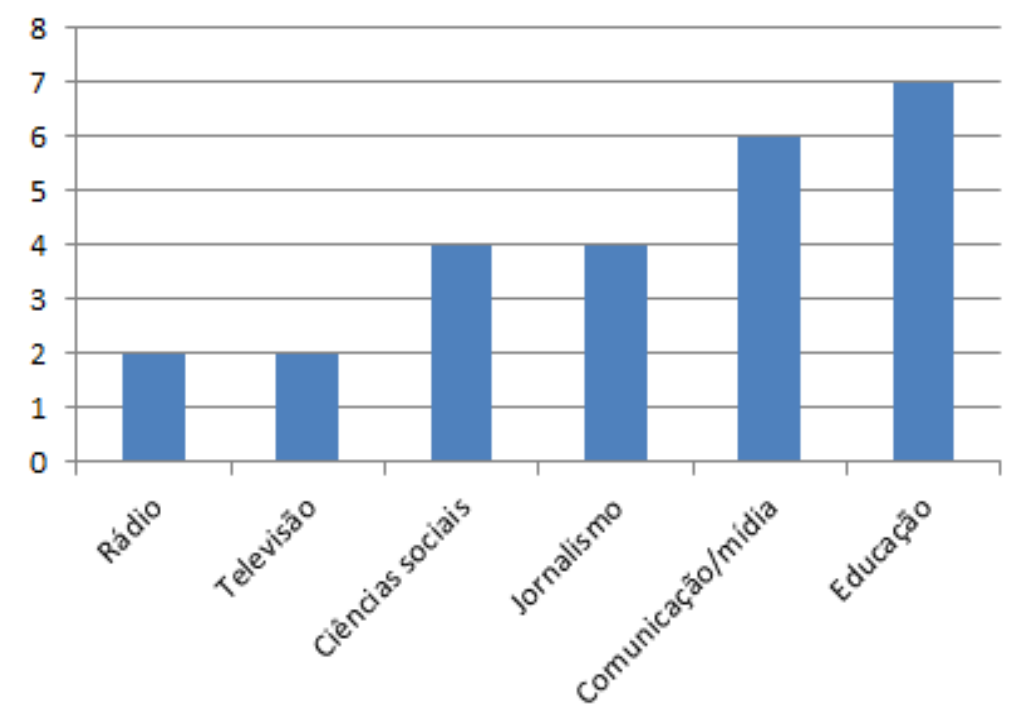

Ilustração 15. Principais temas abordados na seção Artigos Internacionais de Comunicação \& Educação entre os anos de 2004 e 2011. 
Entre os autores que já colaboraram com essa seção, estão os teóricos e pesquisadores Giovanni Bechelloni, da Universidade de Florença (Itália); Mário Kaplún (Uruguai); Jesús Martin-Barbero (Universidade Nacional da Colômbia); Guillermo Orozco Gómez (Universidade de Guadalajara, México) e Robert White (Universidade Gregoriana, Itália). A seguir, as principais ocorrências e perfis dos autores à época da publicação:

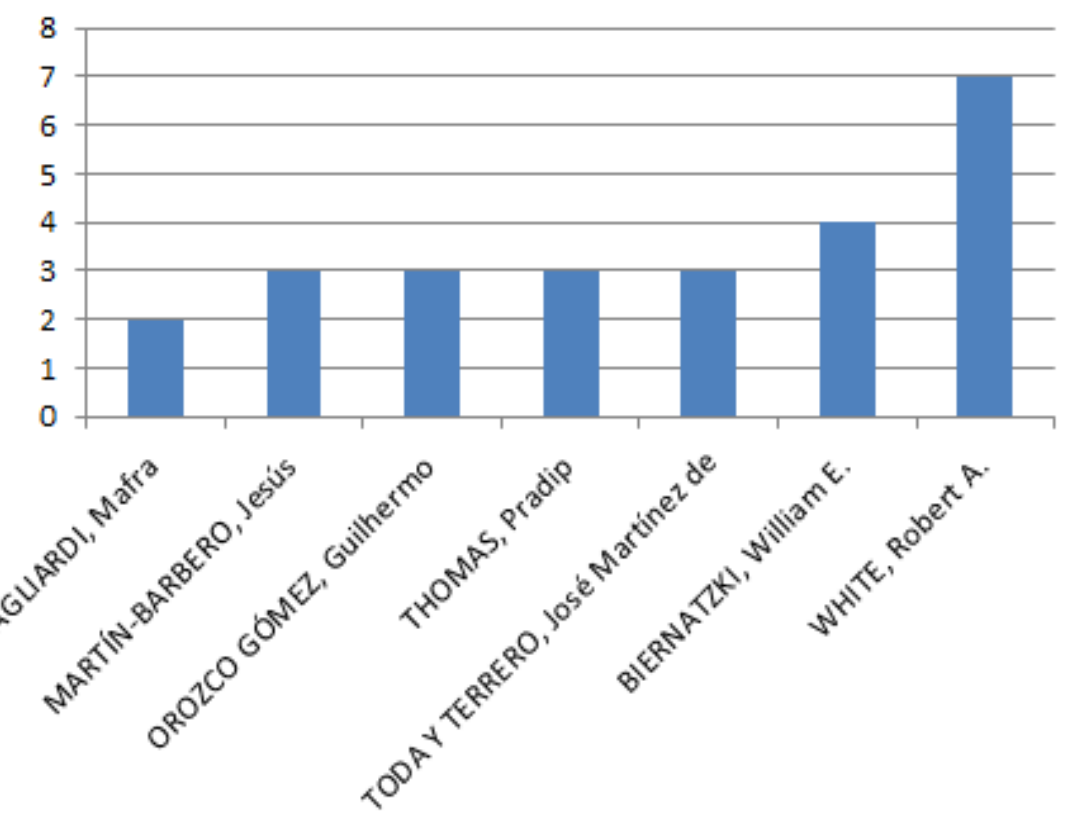

Ilustração 16. Principais autores que colaboraram com a seção Artigos Internacionais.

BIERNATZKI, William E. - PhD, editor da revista Communication Research Trends, do Centro de Estudos de Comunicação e Cultura da Universidade de Saint Louis, EUA. GAGLIARDI, Mafra - Professora do Departamento de Ciência da Educação da Universidade de Padova, Itália.

MARTÍN-BARBERO, Jesús - Filósofo. Assessor do Instituto de Estudos sobre Culturas e Comunicação da Universidade Nacional, Colômbia.

OROZCO GÓMEZ, Guillermo - Professor Investigador do Departamento de Estudos da Comunicação Social Universidade de Guadalajara, México.

THOMAS, Pradip - Professor Associado na área de comunicação e mudança social, direito à comunicação e Economia Política da Comunicação na Índia.

TODA Y TERRERO, José Martinez de - Professor Doutor, Pesquisador do Centro Interdisciplinar de Comunicação Social da Pontifícia Universidade Gregoriana, Itália. 
WHITE, Robert A. - Professor do Centro de Estudos Interdisciplinares da Universidade Gregoriana, Roma, Itália.

\section{Experiência}

A seção Experiência, em que educadores relatam a aplicabilidade dos conceitos teóricos, discutindo métodos, resultados e desafios das atividades, foi voltada, durante a primeira década, essencialmente aos temas ligados à educação formal. A partir disso, abordou-se os meios utilizados para a aplicação dos conceitos (jornal, leitura, produção de textos, poesia) junto às disciplinas constantes, especialmente, do Ensino Fundamental (ele, em si, também um tema recorrente de abordagem dos textos). Uma das formas mais utilizadas para aplicar conhecimentos estaria ligada a atividades de cunho jornalístico, utilizando, especialmente, a palavra escrita. Temas como autoestima, criatividade e cotidiano (dentro de ciências sociais) também mostram a preocupação dos educadores em aproximar os conteúdos do cotidiano dos alunos, assim como em se aproximar da construção dos valores pessoais dos mesmos.

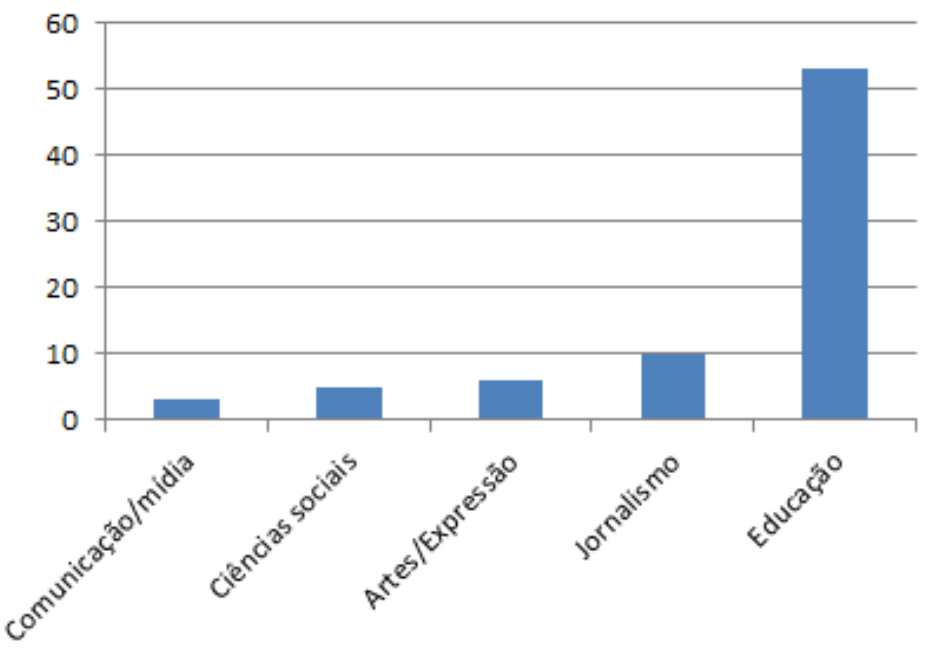

Ilustração 17. Principais temas abordados na seção Experiência de Comunicação \& Educação entre os anos de 1994 e 2003.

Já a segunda década traz uma maior diversificação dos assuntos abordados, especialmente no que diz respeito aos veículos de comunicação e expressão utilizados durante as atividades. $\mathrm{O}$ uso das novas tecnologias aparece de forma recorrente entre as 
experiências relatadas, como se pode comprovar por meio do aparecimento de temas como interatividade, hipertexto e ferramenta wiki (aqui incluídos dentro do tema novas tecnologias). A preocupação com a formação e capacitação de professores para lidar com os meios de comunicação persiste também nessa fase da revista.

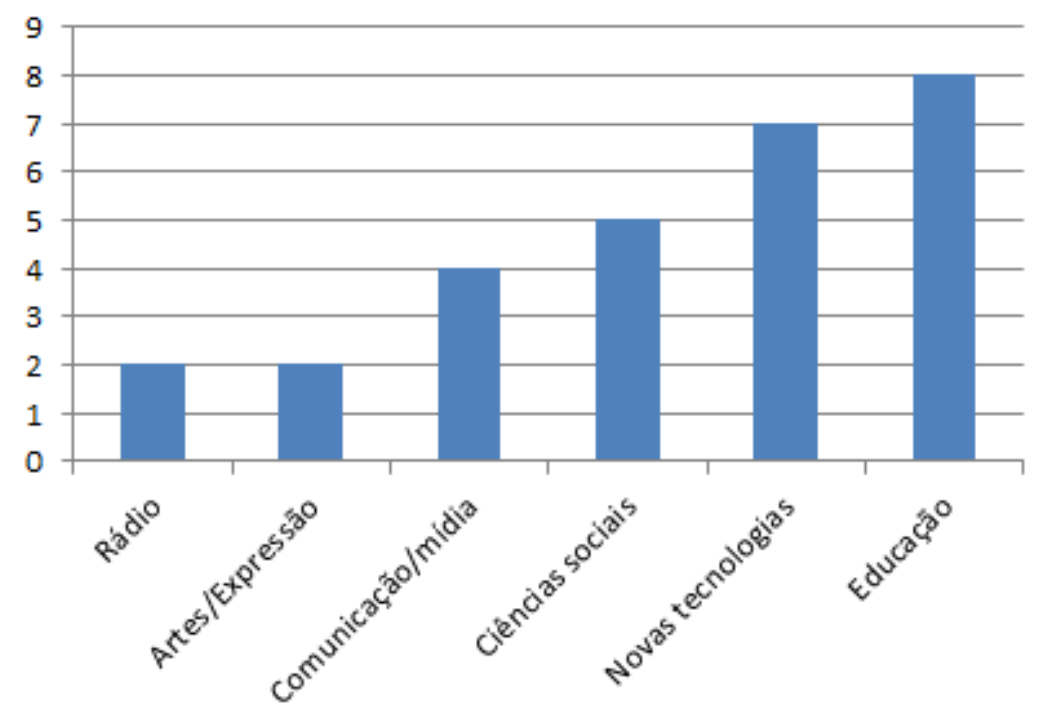

Ilustração 18. Principais temas abordados na seção Experiência de Comunicação \& Educação entre os anos de 2004 e 2011.

\section{Entrevista}

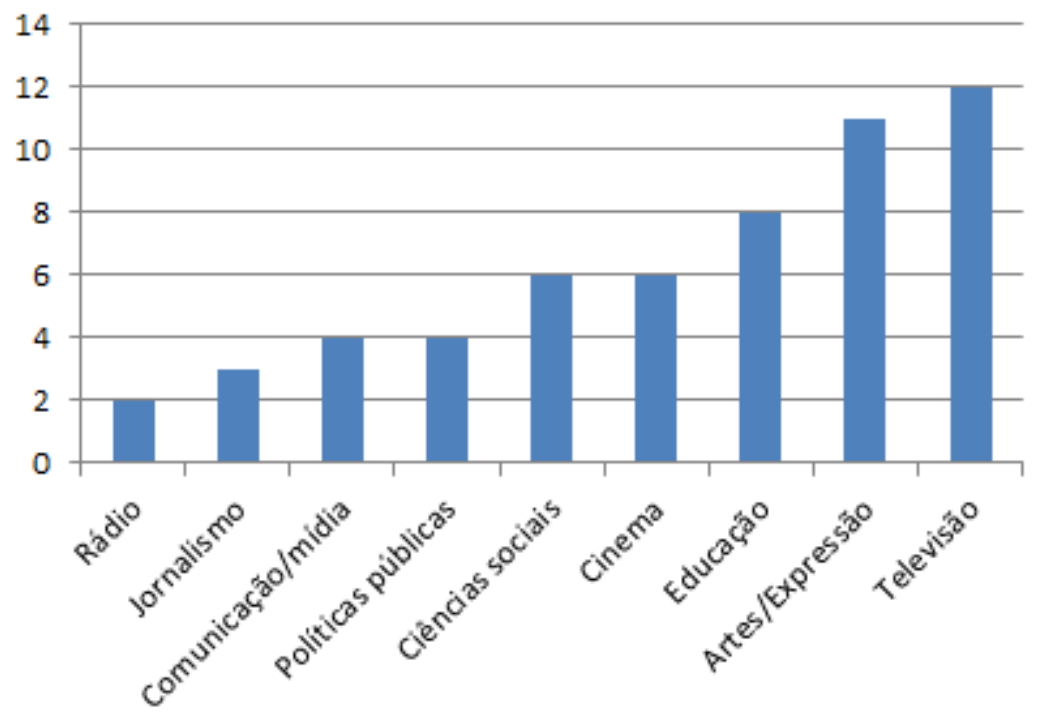

Ilustração 19. Principais temas abordados na seção Entrevista de Comunicação \& Educação entre os anos de 1994 e 2003. 
Mais uma vez, o tema Televisão ocupa destaque entre os assuntos abordados na seção, que durante a primeira fase da revista contou com a participação de convidados diversificados como os pesquisadores e teóricos da comunicação Armand Mattelart, Guillermo Orozco Gómez e Jesús Martín-Barbero; os cineastas brasileiros Carla Camurati e Nilton Travesso; o publicitário Duda Mendonça; os atores Eva Wilma, Gianfrancesco Guarnieri e José Wilker; o jornalista Jânio de Freitas; o dramaturgo Lauro César Muniz; o escritor, compositor e ator Mário Lago; o jornalista Mino Carta e o sociólogo Renato Ortiz. O resultado foram temas grandemente ligados à cultura e as artes, além da preocupação com a educação e com a cidadania - sendo a maioria das palavras-chave ligada, de alguma forma, ao universo televisivo ou audiovisual.

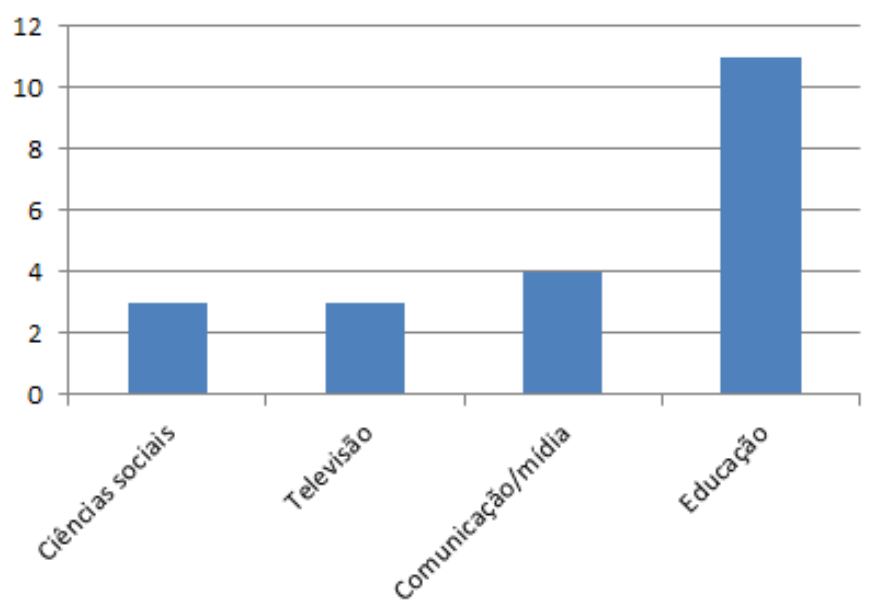

Ilustração 20. Principais temas abordados na seção Entrevista de Comunicação \& Educação entre os anos de 2004 e 2011.

Já a partir da segunda década da publicação, o tema televisão cede o primeiro lugar para o tema educação, seguido de comunicação. Entre os entrevistados, estiveram o ator e apresentador Antonio Nóbrega, o cineasta Cao Hamburguer, o artista gráfico Elifas Andreato, o jornalista Heródoto Barbeiro e os músicos Paulo Tatit e Sandra Peres - além do professor francês Yves Schwartz, do teórico argentino Jorge Huergo e da professora em Ciências da Educação Geneviève Jacquinot-Delaunay. Participaram ainda outros nomes importantes para a história da comunicação e das ciências sociais no Brasil, como Francisco Whitaker, co-fundador do Fórum Social Mundial, e André Barbosa Filho, especialista em comunicação e assessor especial, durante o Governo Lula, do Gabinete Civil da Presidência da República para assuntos relacionados a políticas públicas de comunicação. 
O perfil dos entrevistados, assim como a condução da linha editorial da própria revista, fazem notar a concentração da discussão em torno de grandes assuntos centrais, abrangendo áreas diversas da cultura e da comunicação - que se desdobram em temas menores citados uma única vez ao longo das edições (ver a relação completa na seção Anexos). Pode-se notar, dessa forma, uma disposição da revista - uma vez que o direcionamento desta seção é sempre dado diretamente pela equipe editorial - em privilegiar a discussão conceitual, talvez mais do os procedimentos ou meios de comunicação em si. Costa explica essa tendência:

Houve uma tentativa de valorizar essas outras iniciativas, pensando a educação de uma forma mais abrangente e flexível. Eu chamaria de uma "microeducação" - você pode fazer um projeto bom para atender a poucos, para determinados objetivos e em curto espaço de tempo, com resultados melhores, assim como acontece com a micropolítica, com a microsociologia, com a microciência, que são a especialização, o recorte e o dado. Por outro lado, acho que houve mudanças na escola de comunicações - de professores, de grupo, além de uma tendência da própria comunicação, voltada para o entendimento das mídias. E a revista, de certa forma, refletiu e acompanhou essas mudanças. ${ }^{106}$

\section{Depoimento}

A seção Depoimento foi criada com o intuito de retratar experiências de vida, trabalho ou episódios específicos de profissionas cujo perfil tivesse, de alguma forma, relação com as áreas de comunicação, educação ou cultura. Ou, de acordo com as palavras de Baccega no texto de apresentação do primero número da revista:

Depoimentos é uma seção escrita por profissionais que "fazem" os meios. Nela se conta, por exemplo, como foi realizada uma determinada propaganda, como é elaborada uma novela, como se dá a produção de um programa de televisão ou de rádio, como se faz um jornal diário ou uma revista (de notícias ou em quadrinhos, ou outras), como se produz e

\footnotetext{
${ }^{106}$ Entrevista concedida pela professora Maria Cristina Castilho Costa à pesquisadora em 10.01.2012.
} 
divulga um livro, etc. ${ }^{107}$

Durante a primeira década da revista, esta seção contou com a presença de nomes diversificados dessas áreas - como a atriz Rosi Campos, o desenhista Paulo Caruso, os jornalistas Neide Duarte, Ricardo Kotscho e Chico Pinheiro, o dramaturgo Lauro César Muniz e a escritora Renata Pallotini. Mantendo sua característica de resgate de vivências e experiências marcantes, teve como temas abordados as áreas de atuação dos participantes - rádio, reportagem, teatro e jornalismo, este último em primeir lugar em ocorrências - assim como episódios importantes da história do país, entre eles a ditadura militar.

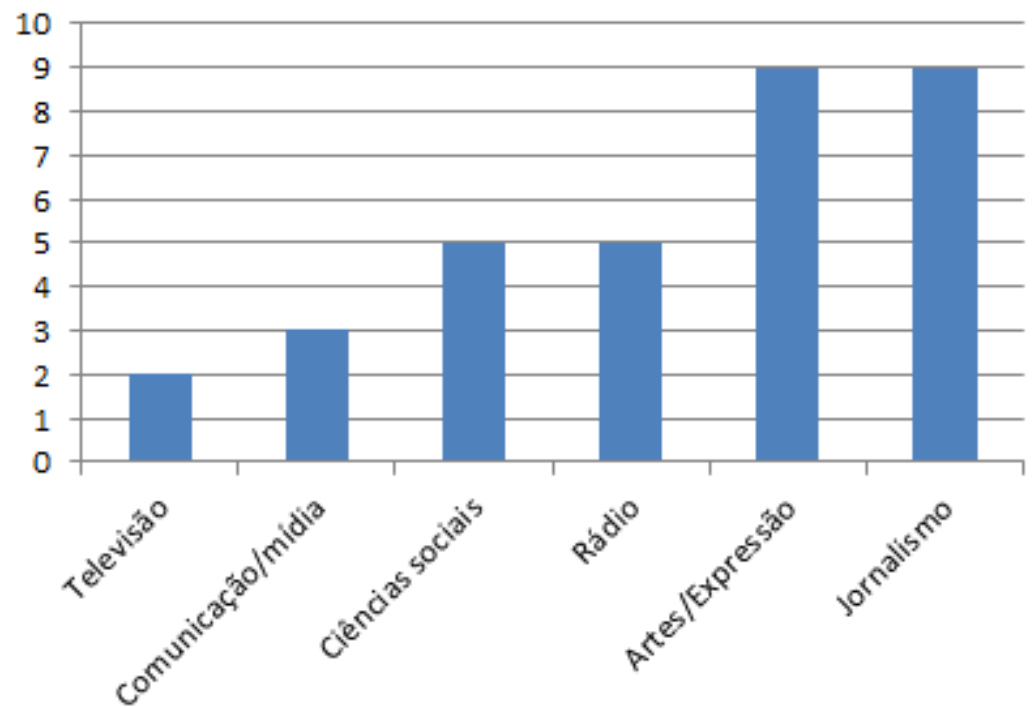

Ilustração 21. Principais temas abordados na seção Depoimento de Comunicação \& Educação entre os anos de 1994 e 2003.

Já a partir da segunda década da história da revista, os temas aparecem ampliados, abrangendo desdobramentos das áreas de artes, cultura e comunicação. Assuntos mais relativos às demandas da contemporaneidade e menos ligados diretamente ao resgate histórico - como Gestão da Comunicação, Literatura infantojuvenil e arte-educação - aparecem também nesta segunda fase. Entre os participantes da seção neste período, estiveram os escritores Fanny Abramovich, Pedro Bandeira e Tatiana Belinki; o coreógrafo Ivaldo Bertazzo; o artista plástico Fernando Brennand; o cenógrafo brasileiro Cyro del Nero e a pedagoga Dorina Nowill.

${ }^{107}$ BACCEGA, Maria Aparecida. Do mundo editado à construção do mundo. Comunicação \& Educação, ano 1, n.1. São Paulo, ECA/USP, 1994. p. 10 


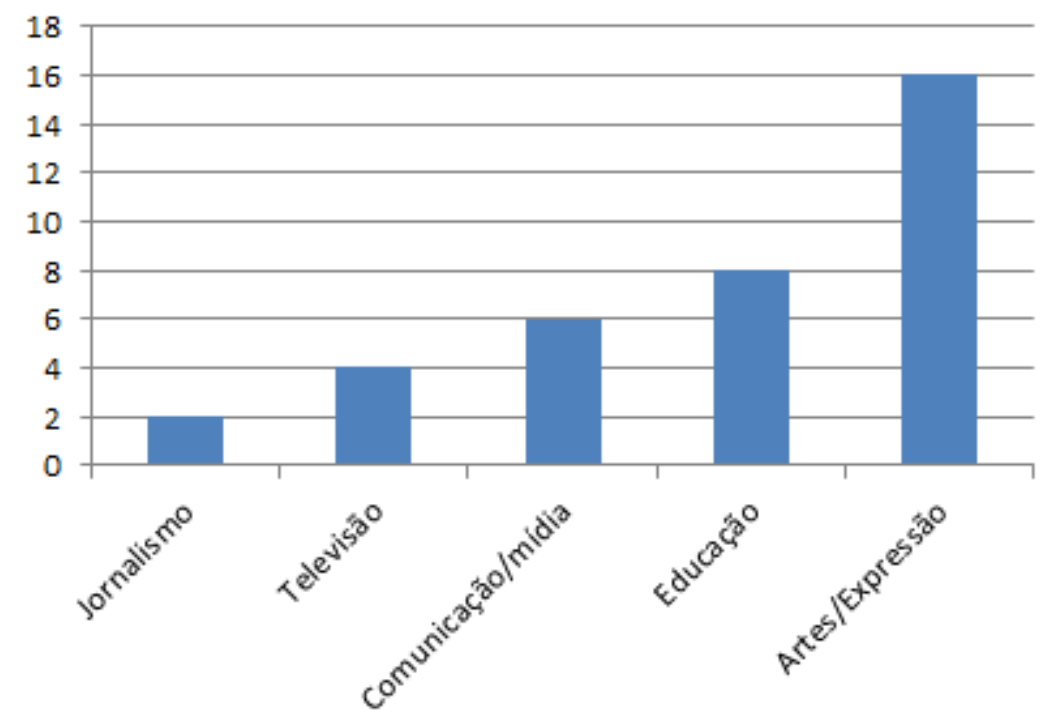

Ilustração 22. Principais temas abordados na seção Depoimento de Comunicação \& Educação entre os anos de 2004 e 2011.

\section{Crítica}

Esta seção, como explica Baccega, traz "críticas sobre a produção dos meios massivos, sobre as 'mensagens' construídas, constituindo, portanto, mais um subsídio para a 'leitura crítica dos meios de comunicação', conforme propõe o texto da nova $\mathrm{LDB}^{108 \%}{ }^{109}$ Contando com a colaboração de acadêmicos e pesquisadores de áreas específicas, a seção dedica-se a analisar peças de comunicação, fatos ou aspectos marcantes relacionados às áreas de interesse da revista, como mostram os temas abordados ao longo de sua trajetória.

Durante a primeira década, os textos abordaram peças comunicacionais ou artísticas como o filme $O$ que é isso, companheiro?, lançado em 1997; a publicidade conhecidamente polêmica da marca italiana Benneton; e outras obras relacionadas à televisão, jornalismo, publicidade ou teledramaturgia.

\footnotetext{
${ }^{108}$ Lei de Diretrizes e Bases da Educação.

${ }^{109}$ BACCEGA, Maria Aparecida. Do mundo editado à construção do mundo. Comunicação \&

Educação, ano 1, n.1. São Paulo, ECA/USP, 1994. p. 10
} 


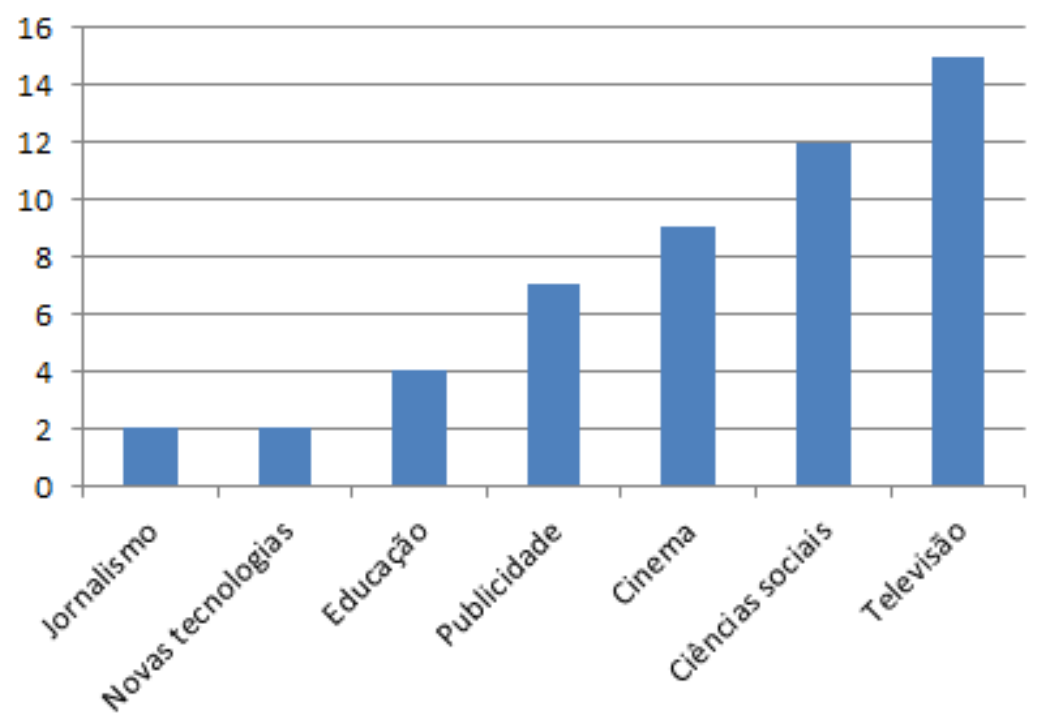

Ilustração 23. Principais temas abordados na seção Crítica de Comunicação \& Educação entre os anos de 1994 e 2003.

Já na segunda fase da revista, além do ambiente escolar, os temas abordados passam a se relacionar mais diretamente, também, com questões ligadas à cidadania e ao meio social - como em comunicação e consumo, hegemonia, espacialidade e identidade. Os assuntos ligados à mediação e à recepção também se mostram com evidência, estando, por sua vez, diretamente relacionados às questões sociais reforçadas nos textos desse período.

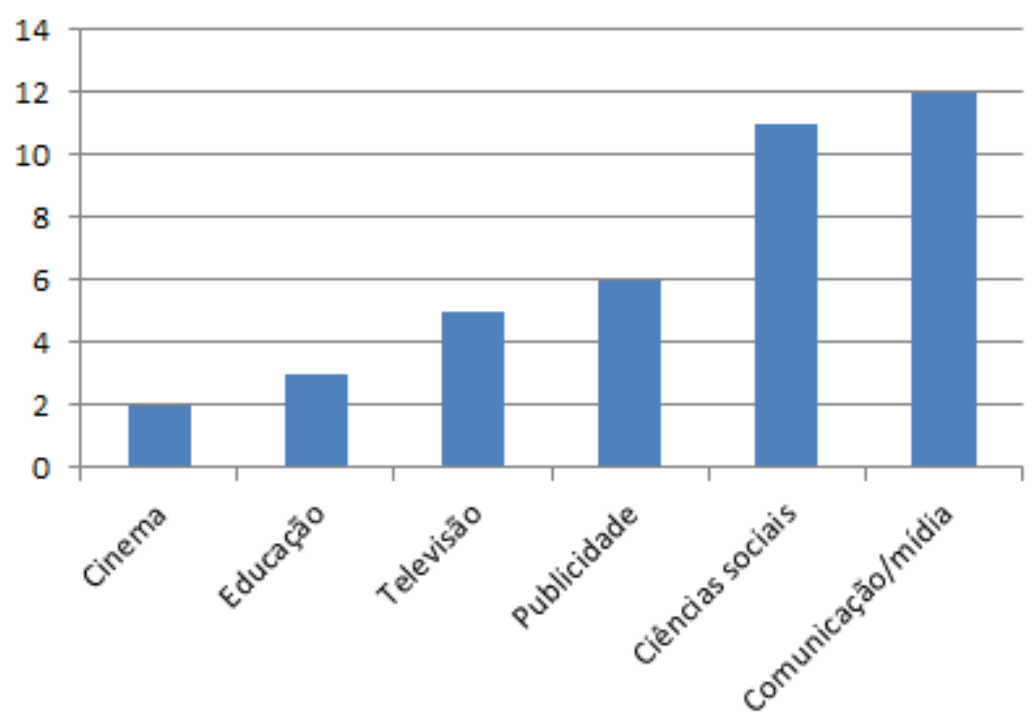

Ilustração 24. Principais temas abordados na seção Crítica de Comunicação \& Educação entre os anos de 2004 e 2011. 


\section{Serviços}

A seção Serviços foi criada com o objetivo de apresentar ao leitor referências úteis para informação ou abordagem, em sala de aula, de obras, eventos, espaços ou materiais ligados à comunicação e educação. Locais como o Memorial do Imigrante ou o Museu do Futebol, em São Paulo, figuraram entre as sugestões para atividades ou ampliação de conhecimentos dentro das duas áreas.

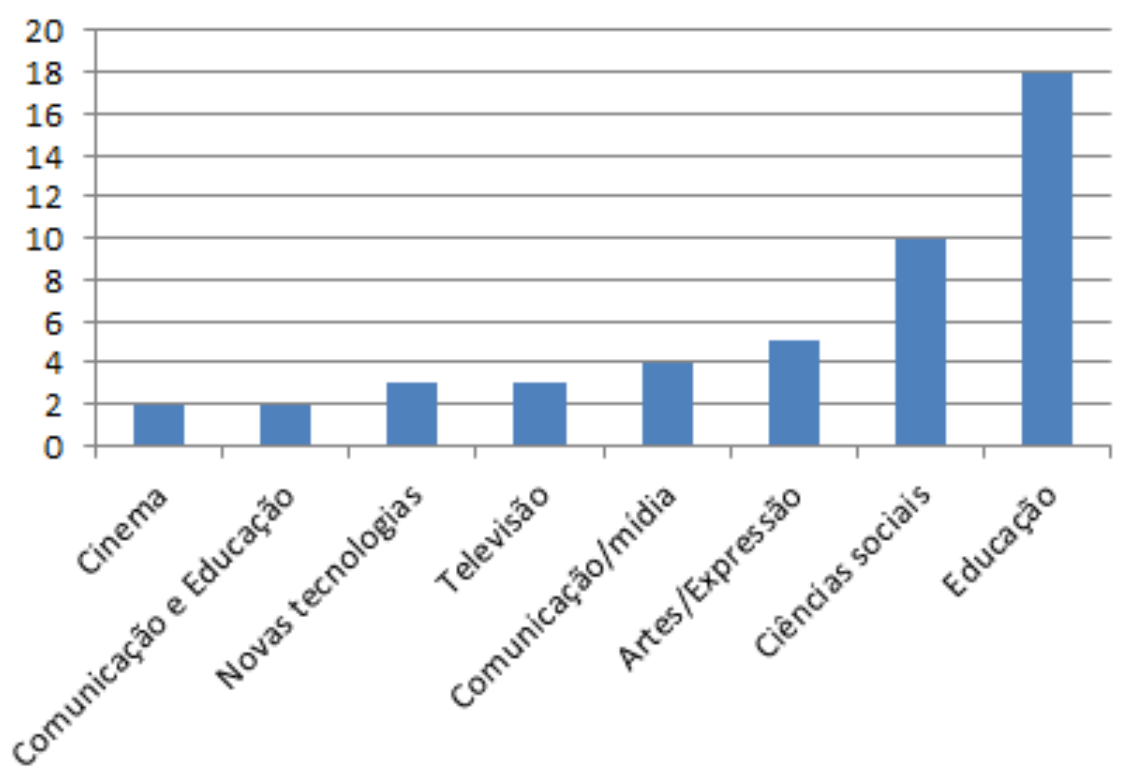

Ilustração 25. Principais temas abordados na seção Serviços de Comunicação \& Educação entre os anos de 1994 e 2003.

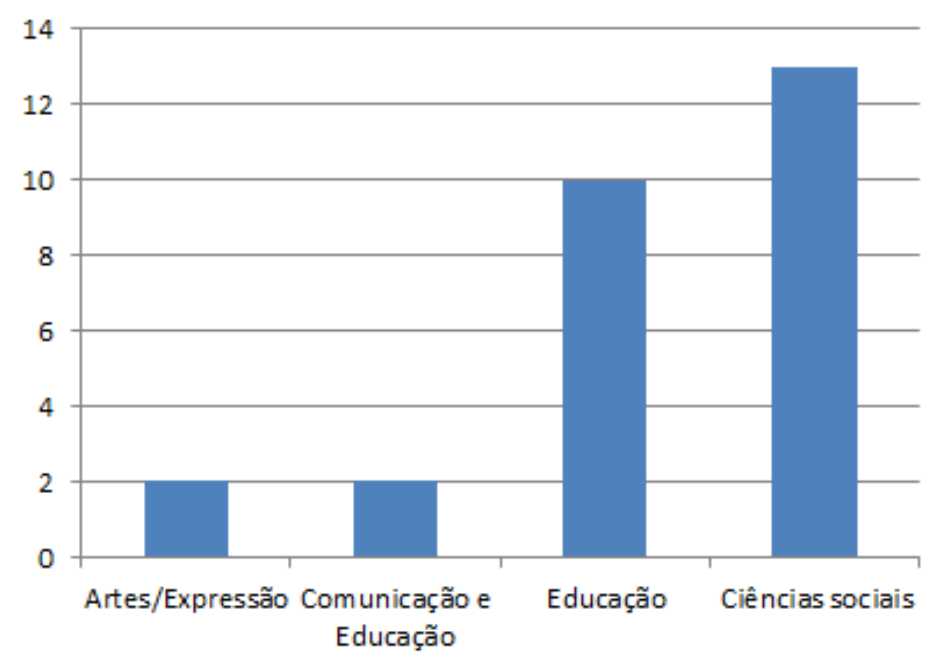

Ilustração 26. Principais temas abordados na seção Serviço de Comunicação \& Educação entre os anos de 2004 e 2011. 
Entre as duas fases da revista, a os temas ligados a ciências sociais ganham gradual destaque, se comparados ao número de ocorrências dos demais assuntos de cada período - mostrando, também aqui, a diversificação de referências ligadas a questões como cidadania e mobilização social. O tema educação, que aparece em primeiro lugar em número de citações no primeiro período, continua em destaque no segundo, mostrando ainda a forte ênfase dada, também, ao trabalho dentro do ambiente escolar enquanto o tema comunicação e educação, como assunto único, ainda registra número menor de ocorrências.

\section{Gestão}

A seção Gestão foi criada em 2006 como espaço para publicação dos projetos de intervenção elaborados pelos alunos do Curso de Gestão da Comunicação, ambiente de origem da revista. Entre os anos de 2006 e 2011, foram publicados trabalhos relacionados às grandes áreas conceituais abordadas pelo curso, traduzindo, também, o perfil de interesse dos alunos participantes. Em primeiro lugar em ocorrências na seção está o tema comunicação/mídia, fortemente relacionado à área de interesse do curso. Assuntos como cidadania e memória também tiveram destaque, dentro de ciências sociais, mostrando o interesse predominante expresso nos projetos desenvolvidos pelos alunos.

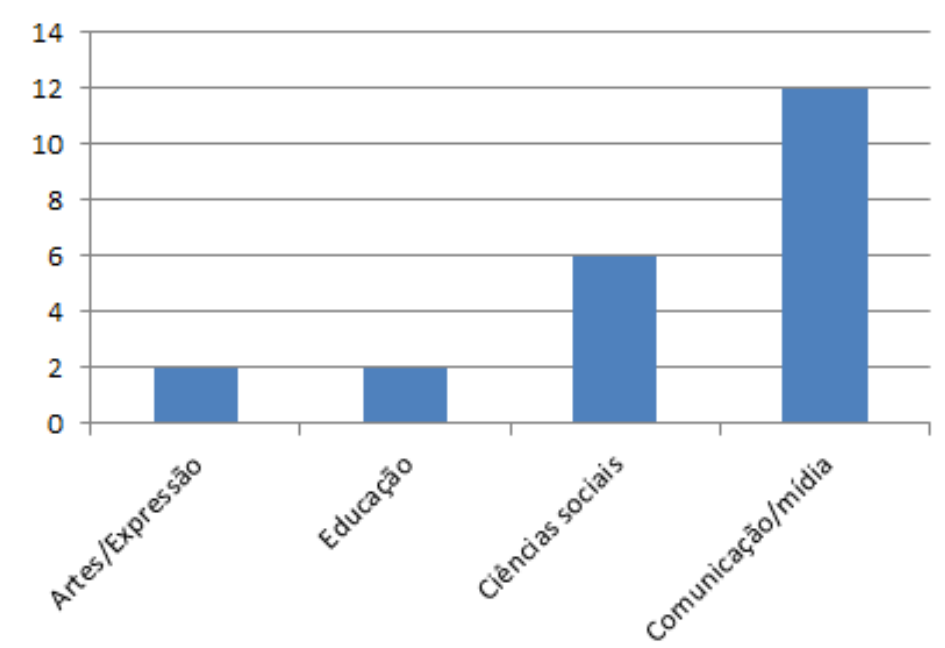

Ilustração 27. Principais temas abordados na seção Gestão de Comunicação \& Educação entre os anos de 2006 e 2011. 


\section{CONSIDERAÇÕES FINAIS}

Mais do que traçar o panorama de uma publicação, relacionando-o com o momento histórico e social vivido por quem contribuiu para sua existência - tanto colaboradores como leitores - o presente trabalho possibilitou, também, uma importante reflexão sobre o papel das revistas científicas na atualidade. Ao oferecer espaço para o diálogo de pesquisadores e profissionais diversos em torno de um objeto comum, constituindo-se em um fórum ágil e coletivo de discussão, Comunicação \& Educação se une a outros importantes veículos divulgadores de inovação científica, como uma publicação dinâmica e suscetível às transformações de sua área, de seu tempo e de suas instituições.

O levantamento estatístico dos artigos da revista, bem como a observação quanto ao conteúdo, abordagem e evolução editorial da mesma, tornaram possível analisar os principais propósitos e acontecimentos responsáveis pela consolidação de Comunicação \& Educação como uma das principais publicações relacionadas aos campos de que trata. Ao longo de sua história, a revista recebeu, discutiu e repercutiu influências que ajudaram a construir seu perfil editorial nos mais diferentes níveis:

- Com a sociedade: a trajetória da revista constitui-se em reflexo do próprio desenvolvimento da sociedade ao longo dos anos - especialmente no que diz respeito às prioridades de abordagem, urgências e necessidades do setor educacional, aliadas às diversas formas - e também contradições - pelas quais a comunicação é vista dentro dos espaços educativos. Temas como a ascensão das mídias digitais, a importância e aplicação da linguagem televisiva em sala de aula, a educação a distância e o advento de um perfil profissional específico para tratar da interface entre comunicação e educação se encontram retratados e discutidos ao longo das edições.

- Com a Escola de Comunicações e Artes da USP: as mudanças históricas discutidas pela revista encontram lugar e são acompanhadas de perto, também, dentro da própria Escola de Comunicações de Artes. Do ponto de vista acadêmico, a publicação ajudou a fortalecer o campo por meio de discussões teóricas, textos e artigos que encontram lugar privilegiado em seu projeto editorial - enquanto constituiu-se, também, em importante canal de divulgação e afirmação de suas práticas, contribuindo com iniciativas educomunicativas dentro e fora da escola. 
- Com o Departamento de Comunicações e Artes: em todas as suas etapas, a revista foi também um meio de expressão das mudanças e do desenvolvimento do Departamento de Comunicações e Artes - primeiramente como veículo do Curso de Gestão de Processos Comunicacionais, reafirmando a importância, para o profissional, do forte embasamento teórico e não apenas tecnicista - e, posteriormente, como espaço de discussão disponibilizado pelo próprio Departamento, na intenção de dar continuidade ao debate estabelecido ao longo dos anos precedentes. A contribuição da revista foi fundamental, também, para que houvesse campo propício à criação do curso de Licenciatura em Educomunicação, em atividade desde o ano de 2011.

- Com o perfil das diferentes editorias: Tal direcionamento foi possível, substancialmente, também em decorrência dos perfis dos próprios Editores que estiveram à frente da publicação - ligados a áreas do saber como dramaturgia, estética, artes e educação, igualmente importantes e complementares aos temas pertinentes às edições - e que, ao lado de especialistas de diferentes áreas, validaram o projeto científico da revista.

A partir dessas reflexões, procuramos elucidar as questões-chave dessa pesquisa:

- Como a publicação, com base em seu modelo editorial, efetiva sua contribuição para a consolidação desta área de interface, com base nos temas propostos e suas abordagens?

Concluímos que a contribuição da revista se dá, primordialmente, a partir da diversidade de temas, da profundidade com que são tratados e da coerência de linhas de pensamento centrais ao longo de sua história - como o tratamento dado às tecnologias, a busca do equilíbrio entre identidade e diversidade cultural, a consolidação acadêmica da interface entre comunicação e educação e a preocupação em aliar a discussão teórica à prática em sala de aula e demais espaços educativos. Como declarado pelos responsáveis pela linha editorial da revista e constatado por meio da análise de seu conteúdo, estas características constituem-se em preocupações constantes da publicação - expressas através, por exemplo, da escolha dos profissionais convidados para seções como Depoimento, Entrevista e Resenhas, que, advindos das mais diversas áreas do saber, acrescentaram sua visão particular de arte, cultura, comunicação e educação às discussões. 
A variedade de temas, aliada à evolução de sua ocorrência - aumento ou diminuição das citações de cada um deles nas diferentes fases estudadas - também é termômetro importante a respeito dos debates públicos realizados no momento de elaboração de cada edição, já que notamos, por meio dos temas abordados, a discussão de notícias, personalidades, programas de televisão, espetáculos ou assuntos de relevância momentânea, porém que tinham algo a acrescentar, de forma perene, ao debate dos temas citados.

Da mesma forma, a interface entre teoria e prática se faz sentir por meio de seções fixas como Atividades em Sala de Aula, Indicações Bibliográficas, Endereços úteis na internet e Gestão.

Citelli detalha o direcionamento da revista nesse sentido:

A permanência da atualidade da revista vem através do traço problematizador de ambos os substantivos “comunicação" $e$ "educação". Ela problematiza isso permanentemente. Nessa perspectiva, o material que a revista fornece é absolutamente atual, já que, na medida em que recebemos e encaminhamos os artigos, ou solicitamos coisas de colegas, esse debate se reatualiza. (...) A revista poderia entender que a educação tenha a ver com algo regulativo, mas acreditamos mais no conceito de transformação, de mudança. Da mesma forma, a publicação não pode dizer respeito somente à mídia ou a interesses da indústria da comunicação. Ela é um processo verdadeiramente humano, cujo objetivo último deve ser justamente aprofundar os mecanismos interlocutivos e fazer as pessoas avançarem no sentido de viver na sociedade um pouco melhor. Nesse sentido, a comunicação não é apenas um instrumento para alcançar um fim: é parte dos processos humanos, é parte de um jogo amplo - tanto positivo quanto negativo. Portanto, a comunicação tem a ver, nessa perspectiva, com processos formativos. ${ }^{110}$

\footnotetext{
${ }^{110}$ Entrevista concedida pelo prof. Adilson Citelli à pesquisadora em 12.01.2012.
} 
Como reflexo direto da contribuição da revista para a consolidação do campo, destacamos seu papel fundamental, a partir dessa análise, para o surgimento e concretização do curso de Licenciatura em Educomunicação, nascido a partir da conscientização e aumento do interesse da comunidade acadêmica tanto brasileira como internacional por essa área de interface. Da mesma forma, o próprio curso vem para legitimar a área e garantir a longevidade dessa mesma discussão.

- Como se dá a evolução editorial da revista, relacionada à conseqüente contribuição aos campos de estudo que aborda?

Ao longo das edições, os temas abordados pela publicação privilegiaram as urgências educacionais e comunicativas presentes na discussão de profissionais de ambas as áreas. Temas como televisão, leitura e jornal, por exemplo, que apresentavam grande ocorrência em seus primeiros números, gradualmente foram dividindo espaço em prioridade de citações - por assuntos relacionados a novas mídias, como internet e tecnologia da informação, ou à característica, ligada à contemporaneidade, do emissorreceptor de informação, como no caso do tema gestão da comunicação.

Temas ligados à participação cidadã e à mobilização social também ganharam espaço ao longo das edições, em contraponto a assuntos mais gerais ou ligados à educação formal, registrados em seus primeiros números - o que mostra, de um lado, a preocupação em discutir os alicerces da ação comunicativa e educacional em suas várias vertentes, presente nos primeiros anos; e, de outro, o aumento de uma consciência e mobilização que gerasse iniciativas em comunicação e educação também fora da escola, num segundo momento de existência da revista. Esse segundo momento reflete, também, uma nova reorganização da sociedade, em que as iniciativas autônomas expressas por ONGs e movimentos sociais encontram mais espaço para existir e se desenvolver.

Costa comenta a postura da revista dentro desse processo histórico, que envolve também a maneira como se pensa o próprio conceito de educação:

A educação como foi concebida, no século XVIII ou século XIX, não pode ser pensada como educação de massa. E nós vivemos numa 
sociedade de massas que tentou massificar a educação. Então, a educação fica se contradizendo, brigando consigo própria. Ou seja: isso que nós fazemos ainda é educação? A idéia da formação, do caráter, da cidadania, são princípios de uma educação não massificante, muito individualizada e muito ligada a uma tomada de consciência, a uma participação social. (...) Na educação massificadora, toda a parte de autonomia do educando, de atitude crítica e intervenção, tende a ser esquecida em favor dos conteúdos. Então, ao longo da história da revista, procuramos também pensar a educação de uma forma mais abrangente e flexível. ${ }^{111}$

Dessa forma, acreditamos que o acompanhamento da linha editorial da revista, seus autores participantes e temas abordados, nos dá bases para traçar um retrato parcial, porém fidedigno, de um momento importante dentro do desenvolvimento da interface entre educação e comunicação no Brasil. A procura por edições de anos passados da revista, tanto presencialmente como via internet, nos demonstra a contemporaneidade de sua produção e o importante papel de registro e memória dos últimos 17 anos de pesquisa e prática em comunicação e educação no país, na América Latina e no mundo - em uma trajetória que se demonstra, ao mesmo tempo, em processo de consolidação, mas também com potencial cada vez mais abrangente de mobilização social e de contribuição para tornar a educação e a liberdade de expressão em valores, verdadeiramente, universais.

Tal consciência revela que a ação do campo comunicaçãoleducação pode ser um dos caminhos para a organização dos excluídos, dos marginalizados, dos invisíveis, de cuja inserção pode resultar a efetiva comunicação para a cidadania. Nesse campo reside um novo modo de contar a história, revivificar o passado, construir uma nova história, que inclua a todos, dando-lhes vez e voz para o grito e para a canção. ${ }^{112}$

\footnotetext{
${ }^{111}$ Entrevista concedida pela professora Maria Cristina Castilho Costa à pesquisadora em 10.01.2012.

112 BACCEGA, Maria Aparecida. Comunicação/Educação e a construção de uma nova variável histórica. Comunicação \& Educação, ano 14, n. 3. São Paulo, ECA/USP, 2009. p. 27.
} 


\section{REFERÊNCIAS BIBLIOGRÁFICAS}

BACCEGA, Maria Aparecida. Do mundo editado à construção do mundo.

Comunicação \& Educação, ano 1, n.1. São Paulo, ECA/USP, 1994. . Comunicação e Tecnologia: Educação e Mercado de

Trabalho. Comunicação \& Educação, ano 1, n. 2. São Paulo, ECA/USP, 1995.

. Comunicação, Direitos Humanos e Cidadania.

Comunicação \& Educação, ano 1, n.3. São Paulo, ECA/USP, 1995.

- Comunicação e mediações. Comunicação \&

Educação, ano 2, n. 4. São Paulo, ECA/USP, 1995.

. Comunicação e cultura. Comunicação \& Educação,

ano 2, n. 5. São Paulo, ECA/USP, 1996.

. Meios de Comunicação: dos homens para os homens.

Comunicação \& Educação, ano 2, n. 6. São Paulo, ECA/USP, 1996.

. Televisão: desafio permanente. Comunicação \&

Educação, ano 3, n. 8. São Paulo, ECA/USP, 1997.

Conhecimento, informação e tecnologia.

Comunicação \& Educação, ano 5, n. 11. São Paulo, ECA/USP, 1998.

Ressignificação da Escola: a circulação da ideologia.

Comunicação \& Educação, ano 6, n. 16. São Paulo, ECA/USP, 1999.

Da comunicação à comunicação e educação.

Comunicação \& Educação, ano 7, n. 21. São Paulo, ECA/USP, 2001.

. Comunicação/Educação e a construção de uma nova

variável histórica. Comunicação \& Educação, ano 14, n. 3. São Paulo, ECA/USP, 2009.

CASTELLS, Manuel. A sociedade em rede. São Paulo: Paz e Terra, 1999.

CERTEAU, Michel de. A Escrita da História. São Paulo: Forense, 2006.

CITELLI, Adilson. Outras linguagens na Escola. São Paulo: Cortez, 2000. (org.). Comunicação e Educação: a linguagem em movimento.

São Paulo: SENAC, 2000.

Ensinar e aprender com textos não escolares. São Paulo: Cortez, 2003. 
Palavras, meios de comunicação e educação. São Paulo: Cortez,

2006.

Comunicação e educação: convergências educomunicativas.

Comunicação, Mídia e Consumo, vol. 7, n. 19. São Paulo, ESPM, 2010.

e COSTA, Maria Cristina Castilho (orgs.). Educomunicação,

construindo uma nova área de conhecimento. São Paulo: Paulinas, 2011.

COSTA, Maria Cristina Castilho. Ficção, Comunicação e Mídias. São Paulo: SENAC, 2002.

Dificuldades e prazeres de uma publicação.

Comunicação \& Educação, ano 15, n. 1, 2010.

COVRE, Maria de Lourdes Manzini. O que é Cidadania. São Paulo: Editora Brasiliense, 2006.

ENTMAN, Robert. Framing U.S. Coverage of international news: contrasts in narratives of the KAL and Iran Air incidents [Cobertura internacional de notícias: contrastes nas narrativas do KAL e dos incidentes da Iran Air]. Journal of Communication, vol. 41, n. 4. Washington, International Communication Association, 1991.

FALCÃO, Maria do Carmo. Cotidiano: conhecimento e crítica. São Paulo: Cortez, 1989.

FERREIRA, Sueli Mara Soares Pinto; TARGINO, Maria das Graças. Métricas alternativas de avaliação do impacto e do uso de revistas eletrônicas: estudo em ciências da comunicação. In: FERREIRA, Sueli Mara Soares Pinto; TARGINO, Maria das Graças (orgs.). Acessibilidade e visibilidade de revistas científicas eletrônicas. São Paulo: Senac/CENGAGE, 2010.

FIGARO, Roseli. Dez anos de Comunicação \& Educação. Comunicação \& Educação, ano 10, n. 3. São Paulo, ECA/USP, 2005.

FREIRE, Paulo. A importância do ato de ler. São Paulo: Cortez, 1982.

GÓMEZ, Guilhermo Orozco. Professores e meios de comunicação: desafios e estereótipos. Comunicação \& Educação, ano 3, n. 10. São Paulo, ECA/USP, 1997.

HALL, Stuart. A identidade cultural na pós-modernidade. Rio de Janeiro: DP\&A, 2001.

HELLER, Agnes. O cotidiano e a história. São Paulo: Paz e Terra, 2000.

KAPLÚN, Mario. Processos educativos e canais de comunicação. Comunicação \& 
Educação, ano 5, n. 14. São Paulo, ECA/USP, 1999.

LEAL, Plínio Marcos Volponi. Jornalismo Político Brasileiro e a Análise do Enquadramento Noticioso. In: II Compolítica - Congresso da Associação Brasileira dos Pesquisadores de Comunicação e Política. Belo Horizonte, 2007.

LIMA, Solange Martins Couceiro. Comunicação \& Educação: um olhar para a diversidade. Comunicação \& Educação, ano 12, n. 1. São Paulo, ECA/USP, 2007.

LOPES, Maria Immacolata Vassalo de. Pesquisa em Comunicação. São Paulo: Loyola, 2003.

MARTIN-BARBERO, Jesús. Dos Meios às Mediações. Rio de Janeiro: UFRJ, 1997.

MESQUITA, Flávio Agnelli. O dia "D": análise do enquadramento às coberturas de Veja e IstoÉ no domingo anterior às eleições presidenciais do $2^{\circ}$ turno. Anais de Comunicação da Universidade Estadual "Júlio de Mesquita Filho" (UNESP), 2007.

MORETZOHN, Sylvia. Pensando contra os fatos. Jornalismo e cotidiano: do senso comum ao senso crítico. Rio de Janeiro: Revan, 2007.

MORIN, Edgar. A cabeça bem-feita. Rio de Janeiro: Bertrand Brasil, 2000.

NELSON, OXLEY e CLAWSON apud RESENDE, Letícia Passos. Inovação, estudos CTS e comunicação científica: a divulgação das pesquisas de materiais cerâmicos e nanotecnologia. 2004. Dissertação (Mestrado) - Centro de Educação e Ciências Humanas da Universidade Federal de São Carlos.

PIRES, Suzana Simões Ribeiro. Comunicação \& Educação - novas propostas de gestão da comunicação. 2005. Dissertação (Pós-graduação em Gestão de Processos Comunicacionais) - Departamento de Comunicações e Artes da Escola de Comunicações e Artes da Universidade de São Paulo.

REESE, Stephen D.; GANDY, Oscar H.; GRANT, August E. Framing Public Life. Perspectives on media and our understanding of the social world. [Enquadrando a vida pública. Perspectivas de mídia e de entendimento da vida social] Mahwah: Lawrence Erlbaum Associates, 2011.

RESENDE, Letícia Passos. Inovação, estudos CTS e comunicação científica: a divulgação das pesquisas de materiais cerâmicos e nanotecnologia. 2011. Dissertação (Mestrado) - Centro de Educação e Ciências Humanas da Universidade Federal de São Carlos.

SCHEUFELE, Dietram A. Framing as a Theory of Media Effects [Enquadramento 
como uma teoria de efeitos de mídia]. Journal of Communication, 49. Washington, International Communication Association, 1999.

SFEZ, Lucien. A comunicação. São Paulo: Martins Fontes, 2007.

SOARES, Ismar de Oliveira. Educomunicação: o conceito, o profissional, a aplicação. São Paulo: Paulinas, 2011.

EAD como prática educomunicativa. Revista USP, n.

55. São Paulo, USP, 2002.

Educomunicação: um campo de mediações.

Comunicação \& Educação, ano 7, n. 19. São Paulo, ECA/USP, 2002. NCE - A trajetória de um núcleo de Pesquisa da USP.

Comunicação \& Educação, ano 10, n. 1. São Paulo, ECA/USP, 2005.

A contribuição da revista Comunicação \& Educação para a criação da Licenciatura em Educomunicação. Comunicação \& Educação, ano 14, n. 3. São Paulo, ECA/USP, 2009.

SOARES, Murilo César. Análise de enquadramento. In: DUARTE, Jorge e BARROS, Antonio (orgs.) Métodos e Técnicas de Pesquisa em Comunicação. São Paulo: Atlas, 2006.

TEDESCO, Juan Carlos. Educação e Novas Tecnologias. Esperanças ou incertezas? São Paulo, Cortez, 2004. 


\section{Referências Eletrônicas}

Apresentação do curso de Especialização em Educomunicação.

http://www.cca.eca.usp.br/especializacao/1222. Acesso em 30.04.2012.

BIZONI, Alessandra Moura. Educomunicação, uma revolução na sala de aula.

Folha Dirigida. Disponível em

http://www.usp.br/nce/wcp/exe/public.php?wcp=/novidades/informe, 7,502.

Acesso em 30.05.2011.

Capes - informações sobre o sistema QUALIS. http://www.capes.gov.br/servicos/salade-imprensa/36-noticias/2550-capes-aprova-a-nova-classificacao-do-qualis. Acesso em 05.05.2012.

Curso de pós-graduação lato sensu Gestão de Processos Comunicacionais.

http://www.eca.usp.br/departam/cca/cca/pos/lato/pos_gestao.htm. Acesso em 03.06.2011.

Lei Nacional de Diretrizes e Bases (LDB). Disponível em

http://portal.mec.gov.br/arquivos/pdf/ldb.pdf. Acesso em 05.05.2012.

Programa do Curso de pós-graduação lato sensu Gestão de Processos

Comunicacionais. http://www.eca.usp.br/gestcom/pdf/programadocurso.pdf. Acesso em 30.04.2012. 


\section{Anexo 1 - Ficha técnica de Comunicação \& Educação}

\section{CONSELHO EDITORIAL}

Adílson Jose Ruiz (Universidade Estadual de Campinas, Unicamp);

Adilson Odair Citelli (Universidade de São Paulo, USP);

Alberto Efendy Maldonado de la Torre (Universidade do Vale do Rio dos Sinos, Unisinos);

Albino Canelas Rubim (Universidade Federal da Bahia, UFBA);

Alice Vieira (Universidade de São Paulo, USP);

Antonio Fausto Neto (Universidade do Vale do Rio dos Sinos, Unisinos/Universidade de Santa Cruz do Sul, Unisc);

Benjamin Abdala Junior (Universidade de São Paulo, USP);

Christa Berger (Universidade do Vale do Rio dos Sinos, Unisinos);

Clovis de Barros Filho (Universidade de São Paulo, USP/Escola Superior de Propaganda e Marketing, ESPM);

Cremilda Medina (Universidade de São Paulo, USP);

Elza Dias Pacheco (†) (Universidade de São Paulo, USP);

Eva Cristini Arruda Câmara Barros (Universidade Federal do Rio Grande do Norte, UFRN);

Irene Tourinho (Universidade Federal de Goiás, UFG);

Ismail Xavier (Universidade de São Paulo, USP);

Ismar de Oliveira Soares (Universidade de São Paulo, USP);

Jose Luiz Braga (Universidade do Vale do Rio dos Sinos, Unisinos);

José Manuel Morán (Universidade de São Paulo, USP/Universidade Norte do Paraná, Unopar);

José Marques de Melo (Universidade de São Paulo, USP/Universidade Metodista de São Paulo, Umesp);

Lindinalva Silva Oliveira Rubim (Universidade Federal da Bahia, UFBA);

Marcius Freire (Universidade Estadual de Campinas, Unicamp);

Margarida Maria Krohling Kunsch (Universidade de São Paulo, USP);

Maria Aparecida Baccega (Universidade de São Paulo, USP/Escola Superior de Propaganda e Marketing, ESPM); 
Maria Cristina Castilho Costa (Universidade de São Paulo, USP);

Maria Immacolata Vassalo de Lopes (Universidade de São Paulo, USP);

Maria Lourdes Motter ( $\dagger$ ) (Universidade de São Paulo, USP);

Maria Thereza Fraga Rocco (Universidade de São Paulo, USP);

Marília Franco (Universidade de São Paulo, USP);

Mayra Rodrigues Gomes (Universidade de São Paulo, USP);

Muniz Sodré Cabral (Universidade Federal do Rio de Janeiro, UFRJ);

Nilda Jacks (Universidade Federal do Rio Grande do Sul, UFRGS);

Raquel Paiva Araujo Soares (Universidade Federal do Rio de Janeiro, UFRJ);

Renata Pallottini (Universidade de São Paulo, USP);

Rosa Maria Dalla Costa (Universidade Federal do Paraná, UFPR);

Rosana de Lima Soares (Universidade de São Paulo, USP);

Roseli Fígaro (Universidade de São Paulo, USP);

Ruth Ribas Itacarambi (Universidade de São Paulo, USP/Faculdades Oswaldo Cruz, FOC);

Solange Martins Couceiro de Lima (Universidade de São Paulo, USP);

Suely Fragoso (Universidade do Vale do Rio dos Sinos, Unisinos);

Virgílio B. Noya Pinto (†) (Universidade de São Paulo, USP)

\section{CONSELHO DE COLABORADORES INTERNACIONAIS}

Cristina Baccin (Decana da Faculdade de Ciências Sociais da Universidade Nacional do Centro da Prov. de Buenos Aires, Argentina);

Geneviève Jacquinot-Daleunay (Université de Paris-VIII e Laboratoire Communication et Politique - CNRS, Paris);

Giovanni Bechelloni (Università di Firenze);

Guillermo Orozco Gómez (Universidade de Guadalajara, Jalisco, México);

Isabel Ferin da Cunha (Universidade de Coimbra);

Jesús Martín-Barbero (Universidade de Guadalajara, Jalisco, México);

Jorge A. González (LabCOMplex - Universidade Nacional Autónoma de México);

José Ignácio Aguaded Gómez (Universidad de Huelva - España);

José Martínez de Toda y Terrero (Centro Interdisciplinar de Comunicação Social Pontifícia Universidade Gregoriana, Itália);

Lúcia Villela Kracke (Chicago State University);

Luís Busato (Diretor de Comunicação - Universidade de Grenoble, França); 
Marcial Murciano Martínez (Decano da Faculdade de Ciências da Comunicação da Universidade Autônoma de Barcelona, Espanha);

Maria Teresa Quiroz Velasco (Universidad de Lima);

Mario Kaplún (†) (Especialista em Comunicação e consultor independente no Uruguai);

Milly Buonanno (Università di Firenze);

Raul Fuentes (Iteso - Universidade Católica de Guadalajara);

Valerio Fuenzalida Fernandez (Pontifícia Universidad Católica de Chile)

Comunicação \& Educação é uma publicação do curso Gestão da Comunicação, do Departamento de Comunicações e Artes da ECA/USP. Integrante da Rede Ibero-Americana de Revistas de Comunicação e Cultura. Indexada no PortCOM/ Portdata (Brasil), Portal Infoamerica (Espanha) e Rebeca (ECA/USP).

\section{CREDENCIAMENTO E APOIO FINANCEIRO DO PROGRAMA DE APOIO} ÀS PUBLICAÇÕES CIENTÍFICAS PERIÓDICAS DA USP

\section{COMISSÃO DE CREDENCIAMENTO}

Editores: Adilson Odair Citelli e Maria Cristina Castilho Costa

Comissão de publicação: Adilson Odair Citelli; Ismar de Oliveira Soares; Maria Aparecida Baccega; Maria Cristina Castilho Costa; Maria Immacolata Vassalo de Lopes; Maria Lourdes Motter (†); Roseli Fígaro; Solange M. Couceiro de Lima; Virgílio B. Noya Pinto $(\dagger)$

Editora executiva: Juliana Winkel - MTB 31.205

Jornalista responsável: Ismar de Oliveira Soares - MTB 10.104

Assessora editorial: Cristine Vargas Pereira

Projeto gráfico - Capa: Telma Custódio

Miolo: Midiamix Soluções Editoriais

Produção de arte: Telma Custódio

Tradutores: Mariane Harumi Murakami e Maria Laet (Inglês) e Wilson Alves Bezerra (Espanhol)

Coordenação de revisão: Marina Mendonça

Revisão: Ana Cecilia Mari

Produção e distribuição

Paulinas Editora 


\title{
Anexo 2 - Conteúdo integral das entrevistas em profundidade
}

\author{
Professora Maria Cristina Castilho Costa
}

Escola de Comunicações e Artes, 10.01.2012

\section{Quais as principais transformações pelas quais a revista passou desde seu início até hoje?}

Temos 3 níveis de transformação envolvendo a revista. $\mathrm{O}$ primeiro interno à própria revista, que é o fato de que ela teve uma editoria da prof. Bacegga, até 2004. É claro que a mudança foi influenciada pela formação dos editores, porque a professora Bacegga vem da área de letras e da educação formal. Eu venho da sociologia, de uma área de cultura e de educação não-formal, envolvendo também a questão das artes, da intervenção social e do terceiro setor. Então, nitidamente, houve uma mudança no enfoque do que é a educação. Como a ECA é da área de comunicação, nessa área isso é menos mítico. Mas na área de educação, seguramente, eu e a professora Bacegga temos experiências muito diferentes.

E eu, particularmente, como editora, sempre me bati por um conceito mais amplo e irrestrito de educação. Por várias razões: primeiro porque sempre trabalhei relacionada à área de terceiro setor - na Secretaria da Cultura eu era assessora dos museus do interior, com a tarefa de ajudar o secretário a pensar nos museus do interior, quais eram de interesse local, quais eram de interesse estadual. Desenvolvi um projeto de museu da cidade para a cidade de Tupã, que queria uma parceria com a secretaria da cultura. Antes disso, tinha passado pelo instituto cultural Itaú e trabalho, há 25 anos, na Editora Moderna com projetos didáticos e paradidáticos. Então, tenho uma longa experiência com a educação não-formal - e, desde que assumi a revista, tentei passar isso.

Para além dessa experiência, eu acho que a educação formal está em crise, porque a educação como foi concebida, no século XVIII ou século XIX, não pode ser pensada como educação de massa. E nós vivemos numa sociedade de massas que tentou massificar a educação. Então a educação fica se contradizendo, brigando consigo própria. Ou seja: isso que nós fazemos ainda é educação? A idéia da formação, do caráter, da cidadania, são princípios de uma educação não massificante, muito individualizada e muito ligada a uma tomada de consciência, a uma participação social. E você não pode fazer isso com as massas. Sendo assim você acaba, na educação massificadora, na minha opinião, caindo no conteudismo. Não é o comportamento, não é a atitude. É muito difícil, porque você pode dizer o que o indivíduo pode fazer, pensar, ser como cidadão. Você não consegue pensar numa massa, no que ela pode ser. Isso sempre foi um impasse da sociologia, da urbanização. Uma massa em movimento é uma rebelião. Mas um indivíduo em movimento não é, necessariamente, um revolucionário. Então, toda essa parte de autonomia do educando, de atitude crítica e intervenção, tende a ser esquecida em favor dos conteúdos.

Eu acho que a educação formal está num beco sem saída - e isso está dando espaço para a educação não-formal, que não tem passado e que é mais flexível e adaptável, de escolher determinados focos e objetivos e atuar de uma maneira consistente, seja para fazer museus no interior, seja para criar uma base de dados sobre a arte brasileira. 
Então, são iniciativas mais focadas, mais diretivas, de curto e médio prazo, que são mais fáceis de serem bem-sucedidas do que a educação formal, que se pretende de longo prazo, com uma abrangência muito maior. Acho isso positivo.

Então, houve uma tentativa de valorizar essas outras iniciativas, pensando a educação de uma forma mais abrangente e flexível. Eu chamaria de uma "microeducação" - você pode fazer um projeto bom para atender a poucos, para determinados objetivos e em curto espaço de tempo, com resultados muito melhores. Assim como acontece com a micropolítica, com a microsociologia, com a microciência, que são a especialização, o recorte e o dado. Acho que essa mudança a revista teve.

Por outro lado, acho que houve mudanças na escola de comunicações. Mudanças de professores, de grupo, além de uma tendência mais tecnicista a própria comunicação, voltada para o entendimento das mídias. Talvez o Departamento tenha acompanhado a tendência da escola para uma formação mais técnica e mais profissionalizante. Daí a licenciatura em Educomunicação e tudo mais. E, finalmente, com as novas tecnologias. Acho que a educação não-formal está começando a se profissionalizar, a ser menos assistencialista. Então, ela absorve mais o que a academia está fazendo. Até algum tempo atrás, essas iniciativas eram mais voltadas para a militância, para a filantropia, para o engajamento político-partidário. Era mais importante ter um profissional adepto do que bem-formado. Por exemplo, na área de alfabetização de adultos, não tinha tanta importância a formação profissional daquele professor, mas o grau de envolvimento com a causa. E acho que a instabilidade dessas iniciativas acabou exigido uma formação profissional mais apurada. Observo isso iniciativas como a Escola Aprendiz, ou o próprio Itaú Cultural. Quando entrei no Instituto, eu era a primeira pessoa da academia a trabalhar lá. O restante era todo do banco. O banco tinha atividades filantrópicas e artísticas e eles usaram alguns funcionários do banco que tinham interesse por essas áreas para trabalhar com aquilo. Eu fui a primeira pessoa de fora, que nunca tinha trabalhado no banco, a entrar no Instituto. E por isso era vista com muita desconfiança. Hoje eu já sei que os processos seletivos buscam pessoas de fora. Praticamente já não existe mais nenhum bancário. Acho que isso aconteceu com muitas iniciativas. Não é mais a causa ou a militância que vai importar tanto. Você precisa conhecer bem aquilo, ser um bom profissional, ter formação, recursos. Acho que já existem cursos que vão muito para essa área de terceiro setor.

Acho importante também lembrar que, no Departamento, os professores envolvidos com a revista estiveram envolvidos também em projetos de aplicação: o Educom.radio, Educom.TV. O Ismar, a Roseli, o Adilson, a prof. Baccega, eu, trabalhamos nesses projetos. Então, inevitavelmente, também a história do departamento acaba influenciando o enfoque. Houve uma resposta da sociedade civil no sentido de saber para que servia aquilo que a gente dizia que sabia. Acho interessante que não foi a área das organizações não-governamentais que mais se aproximou da academia; ao contrário, foi o setor público. Ou seja, quase todos os nossos projetos são com o setor público. Eu diria até que a academia se aproximou mais das políticas públicas do que do terceiro setor - embora o terceiro setor tenha empregado pessoas mais qualificadas, não chegou a formar propriamente uma parceria. A idéia de você atuar independente das pressões de mercado ainda é algo importante para a educação, e isso se deve muito a essa questão do mercado. Educação é investimento e não se pode pensar em termos de lucros imediatos. E a educação, em última instância, é uma atribuição do setor público e 
ele está meio sem saber o que fazer. Então essas parcerias foram muito bem-vindas. Nós somos uma instituição pública, o que traz sintonia, convergência.

Nosso projeto editorial sempre foi o de dar voz a quem não tinha voz. Ou seja, falar das iniciativas pioneiras da América Latina, de professores e autores que vinham para cá ou que viajavam, desvendar o campo da comunicação para o leitor.

\section{Como se define, nesse contexto, o hibridismo da revista, ao mesclar seções acadêmicas com outras de cunho jornalístico?}

O hibridismo da revista é um calcanhar de Aquiles. Muitas vezes fomos cobrados por não fazermos uma revista científica, ou seja, sem preocupação conceitual. Mas existem várias maneiras de construir um conceito, e não necessariamente é só através de teoria mas também do movimento da prática. É uma opção que temos nos recusado a modificar, porque a pressão é para que a revista fique cada vez mais acadêmica - ou seja, todas as pressões que começam a surgir são no sentido de ser mais formal, rigorosa, dar voz àquelas pessoas que sempre tiveram voz. Mas, dentro do possível, temos procurado ser fiéis a nosso propósito. Os credenciamentos da USP, a avaliação da Capes, todos têm exigências de rigor. Então, essa é uma negociação difícil. Sem dúvida, é muito mais fácil fazermos uma revista como todas as outras. Mas acredito, por exemplo, que o sucesso de leitura na internet é devido a essa linguagem mais acessível. As pessoas gostam de ler depoimentos de pessoas conhecidas, por exemplo; isso traz interesse. Existe um lado jornalístico que vende conteúdo.

\section{Professor Adilson Citelli}

\section{Escola de Comunicações e Artes, 12.01.2012}

\section{Quais foram as principais motivações para a criação da revista?}

A revista começou em 1994 e surgiu porque havia um grupo de professores do Departamento interessados em, de alguma maneira, participar dos debates que começavam a ser levantados em torno do tema das relações da comunicação e da educação e não havia, praticamente, material nessa área. Então, esse grupo de professores, fortemente estimulados pela professora Maria Aparecida Baccega, que era então chefe do Departamento, e em função da necessidade, digamos assim, de pesquisa e intelectual do Departamento, colocou-se a ideia de criar uma revista.

Há uma questão também que dizia respeito ao próprio Departamento. Naquele momento, muitos professores já estavam preocupados com o fato de iniciar-se uma espécie de movimento, dentro da ECA, no sentido de reforçar os chamados Departamentos Terminativos - aqueles Departamentos que tinham as suas terminalidades, como Jornalismo, Relações Públicas e assim por diante. E o nosso Departamento, o Departamento de Comunicações e Artes, tinha uma característica, que continua tendo em certa medida, de ministrar as disciplinas para os outros Departamentos. Isso vinha de uma história anterior que estava ligada ao conceito de Ciclo Básico, e o CCA, Departamento de Comunicações e Artes, estaria dentro desse conceito. Então, na medida em que havia na Escola um movimento muito forte para autonomizar cada vez mais os Departamentos profissionalizantes, digamos assim, o CCA também foi perdendo espaço e foi sendo enfraquecido nesse processo. De modo que nós estávamos numa discussão muito forte já naquele ano, no início dos anos 1990, no sentido de criar uma alternativa própria para o Departamento, de sorte que ele também pudesse ter uma graduação. 
A revista vem nesse contexto. 1) Havia, sim, o desejo de criar o que seria uma licenciatura ou um bacharelado com o tempo. 2) Havia um grupo grande de professores que já estava trabalhando com a relação entre comunicação e educação e detectava a necessidade de uma publicação que desse continuidade a esses debates. 3) O fato de que muitos desses professores também queriam ter uma inserção pública maior, um debate maior com a sociedade. Dar a conhecer o que se fazia aqui, ampliar a participação e a discussão. Porque nós vivíamos também um momento forte de redemocratização do país e achávamos que uma publicação poderia ajudar também, digamos, na reconstituição desse país que vinha surgindo a partir da Constituição de 1988, ou seja, a partir daquilo que, teoricamente ou tecnicamente, era dado como o fim da Ditadura Militar. Penso que esses pontos justificam, contextualmente, a ideia da criação da revista.

Quase vinte anos depois, isso acabou realmente resultando nessa licenciatura em Educomunicação. É que lá atrás, em primeiro lugar, não havia clareza se seria uma Licenciatura ou um Bacharelado. Chegamos a encaminhar projetos entre a data de criação da revista e a aprovação do curso de Educomunicação. Pelo menos dois projetos foram encaminhados para que a Escola debatesse e o incorporasse à sua estrutura como um curso novo. Eles tinham o título, naquele momento, de Comunicação e Educação absolutamente conectado com o título da revista. A palavra Educomunicação veio $a$ posteriori. Ou seja, essa preocupação remonta a um daqueles pontos que eu citei anteriormente: o desejo do Departamento de, tendo em vista uma diáspora que estava acontecendo dentro da Escola e o que veio a acontecer progressivamente, de um reforço cada vez maior dentro dos Departamentos, nós também queríamos criar essa alternativa. Então, a criação de um curso para o Departamento e da revista têm essa conexão, inclusive através do nome.

O curso de Gestão, quando surgiu, também estava um pouco dentro do universo de se criar alternativas para o Departamento. Como nós não tínhamos uma terminalidade, criamos um curso de pós-graduação lato sensu. Era um nome oficial para esse tipo de curso, que depois foi retirado pela USP. Atualmente, ele é simplesmente Curso de Especialização. O curso surgiu com duas ou três vertentes também: 1) dar uma alternativa ao Departamento, já que os professores se sentiam um pouco mal em não ter os seus próprios alunos, já que eram alunos de outros Departamentos que passavam por aqui. 2) No fundo, seria uma preparação para criar, futuramente, uma graduação ou uma licenciatura para o Departamento. Portanto, o curso de gestão cumpria, de um lado, uma finalidade de agregação dos professores em torno de um projeto que tinha tudo a ver com o Departamento, já que o curso de Gestão tinha essa preocupação formativa do aluno, claro que numa modalidade mais condensada em um ano e meio, mas ele surgiu exatamente com características muito distintas mesmo dos cursos de lato sensu ou especialização que existiam, que eram cursos mais tópicos, localizados, de 360 horas, com informação mais dirigida, enquanto nós estávamos preocupados com uma formação mais global desse aluno, ou seja, dar a ele uma fundamentação maior na área da comunicação, da cultura, das artes - e foi essa exatamente a ideia de um curso diferenciado, que foi o gestão.

Agora, a partir disso, se articula imediatamente o curso com a revista, que passa a ser o lugar em que se pode ampliar esse debate que não era possível ao Departamento estritamente falando, por uma questão até mesmo institucional. O curso surgia com uma certa marca do Departamento, caracterizando o Departamento. E a revista podia ser, 
agora, porta-voz desse debate, indicando esse interesse do Departamento em debater temas como o da Gestão da Comunicação, da Comunicação e Educação e assim por diante. Tanto é que a revista nasce dentro do Curso de Gestão. Ela não nasceu no Departamento. Nasceu sob o estímulo da prof. Baccega, que logo tratou de construir e viabilizar esse projeto - o que significava, naquele momento, procurar editoras que trouxessem suporte econômico e financeiro para tornar possível a existência da revista. A alternativa que encontramos, inclusive, foi também bastante pioneira nesse sentido, porque talvez pela primeira vez - e dentro da ECA, certamente pela primeira vez - se criou uma revista que se tornou viável materialmente. O que permitiu sua viabilidade foi o fato de termos, de uma maneira tranquila, sem preconceitos, sem óbices, ido a uma grande editora, no caso a Editora Moderna, e feito a proposta a eles no sentido de publicarem a revista - o que acabou acontecendo graças a uma figura muito importante chamada Sérgio Couto, que era editor da Moderna e teve sensibilidade para o que estava acontecendo. Ele, como editor, e depois o Feldre, como dono da Moderna naquele tempo, antes de a editora ser vendida aos espanhóis, perceberam que era um produto editorial novo, que teria possibilidade de ampliar a própria presença da editora num meio mais acadêmico. Do nosso ponto de vista era muito bom, porque tínhamos uma editora que não nos exigia absolutamente nada, o que era muito importante. Não nos fizeram nunca qualquer tipo de ingerência editorial, pelo contrário. Nosso trato é que nós entregaríamos para a Editora um disquete e pronto. Eles então tratariam de traduzir e organizar editorialmente esse material - e inclusive nos pagavam uma jornalista para nos ajudar com esse trabalho, que foi a Roseli Figaro. Era uma troca civilizada entre a universidade, que fornecia a massa crítica da revista, sustentabilidade e imagem positiva para a editora, e a editora, que por seu turno podia ampliar seu catálogo e, sobretudo, colocar à disposição de um público não muito grande, mas importante do ponto de vista da formação de opinião, que eram os professores, pesquisadores e assim por diante. Digo que foi algo sem preconceitos porque muitos achavam estranho que fôssemos a uma editora comercial, mas nós sempre colocamos isso: desde que não haja ingerência e de que possamos fazer o nosso trabalho segundo o que entendemos academicamente correto, não há nenhum problema com esse tipo de envolvimento.

Então, acho que também a revista teve um caráter pioneiro, dentro da ECA com segurança. Eu diria que mesmo dentro da universidade, no que tange ao período e à duração da revista. Pode ser que até mesmo outras revistas tenham adotado esse formato. Eu desconheço alguma que tenha feito esse movimento com tanta disposição no tempo. Daqui a pouco, em 2014, vamos fazer 20 anos da revista. Claro que as editoras mudaram, depois da Moderna vieram outras editoras e hoje nós estamos com as Paulinas - porque as editoras em certo momento perdem o interesse, visto que a revista tem uma tiragem relativamente baixa para os padrões industriais das editoras, incompatíveis com revistas que tiram 2000 exemplares. Então é claro que muitas mantiveram essa relação porque estavam mais interessadas numa questão de marca, de vínculo com a Universidade de São Paulo. São trocas que não comprometem a qualidade do trabalho de ninguém, e que por fim permitiram que a revista tivesse a presença que tem hoje no cenário das áreas de comunicação e educação, e mesmo nas áreas conexas, já que a Comunicação \& Educação faz parte do Qualis de várias outras áreas - como letras e até ciências da saúde, que aparentemente não teria nada a ver com comunicação e educação, porém está lá por ser uma revista que circula no universo da área de saúde. Isto revela que a revista têm uma abrangência além das áreas mais estritas da comunicação e de educação. 
Como podemos definir a linha editorial da revista, de acordo com o perfil de suas seções? Qual a repercussão, no meio acadêmico, de uma revista que não possui conteúdo apenas e estritamente teórico?

Quando foi criada, nós tínhamos consciência de que não queríamos uma revista acadêmica strito sensu, uma apostila reunindo um monte de texto. Queríamos uma revista para fazer uma interlocução social mais ampla, que pudesse ter até um poder ampliado de negociação política no momento histórico de então. Não queríamos, dessa forma, uma revista estritamente acadêmica, mas um diálogo mais próximo com os professores das redes públicas ou privadas, de nível fundamental, de nível médio. Não seria possível, com esse target e essa preocupação editorial, fazer uma revista estritamente acadêmica no sentido de reunião de textos. Queríamos combinar uma estrutura que, ao mesmo tempo, atendesse um certo segmento mais acadêmico, com artigos nacionais e internacionais mais provocativos, mais decorrentes de pesquisa faço um parênteses porque existem algumas revistas acadêmicas que, embora tenham esses moldes, não necessariamente trazem novidades em termos de pesquisa, mas sim comentários, crítica da crítica. Então, é necessário saber também o que seria, hoje, uma revista acadêmica. Mas queríamos cumprir parcialmente uma função acadêmica, por meio da publicação de textos nacionais e internacionais com originalidade acadêmica, ligada às áreas de pesquisa da universidade, ao lado de textos que ampliassem o diálogo com esses setores sociais formados por professores, educadores no sentido amplo do termo, permitindo a esse circuito social entender um pouco melhor a presença da comunicação no mundo que surgia naquele momento - e sobretudo que a escola e a educação formal, por exemplo, pudessem entender o que se passava.

Em 1994, por exemplo, ainda não existia internet na escola. Fazíamos pesquisa com professores naqueles anos em um mundo muito diferente. Quase ninguém tinha computador. A telefonia móvel praticamente inexistia. Então estamos falando de uma situação em que verificava-se que essa "terceira onda" informático-midiática, para usar a expressão do Pierre Levy, que estava surgindo, iria desembocar na escola necessariamente. E isso não poderia ocorrer, enfim, numa perspectiva tecnicista, simplesmente de trocar o projetor de slides pelo datashow. Queríamos mobilizar o debate junto aos educadores e comunicadores para darmos conta dessa nova singularidade que as mídias estavam trazendo, e que as novas tecnologias estavam propondo - mas queríamos dialogar com quem estava na ponta do processo, não apenas com quem estava na universidade.

Dessa forma, essa é uma característica da revista que sempre preservamos, malgrado o fato de que muitas vezes até pudéssemos receber estratos Qualis maiores do que temos. A revista é B2, poderia ser B1 ou qualquer coisa superior, se alterássemos um pouco a rota editorial dela. E teríamos plenas condições de fazer isso, pois a revista tem estrutura para isso. Mas seguimos um projeto político-editorial que contempla o diálogo com um universo profissional, social e cultural maior do que aquele estrito ao mundo da universidade, da pós-graduação, etc. Até porque já há muitas revistas, mesmo na área de comunicação, que se pretendem ou são acadêmicas.

Quanto à repercussão, considero excelente, já que a revista circula muito. Há sites como o Universia, por exemplo, que indicam a revista como a mais acessada da área. Então ela tem um excelente conceito com essa característica. Se de repente pagamos um pequeno preço por isso, já que a revista poderia ter um extrato Qualis maior e não tem 
por um problema de política editorial, vamos manter isso dessa maneira enquanto for possível manter.

\section{Como vê o aparecimento das novas mídias nesse processo histórico, e qual o papel do Departamento nesse contexto?}

Nos anos 1960 e 1970, houve toda uma discussão com relação às tecnologias que estavam entrando na escola, por influências e também conceitos de educadores mais comportamentalistas que definiam isso tudo como Tecnologias da Educação. Dizia-se que era preciso levar as tecnologias para a educação. Bem, esse vetor tecnicista, que é uma leitura muito comportamental e muito responsiva a demandas tecnológicas, cria uma ambiência tecnicista que não se pergunta muito sobre o sentido, o lugar social, a natureza dessas coisas. Eu diria que essa é uma tendência que continua existindo. Diria inclusive que a revista é uma publicação que tenta, na medida do seu alcance, colocar sob cheque essa perspectiva. Se fizermos um levantamento de todos esses anos da revista, veremos que os artigos, mesmo aqueles voltados diretamente para as tecnologias da educação, são mais polêmicos, que questionam mais esse tipo de coisa, transcendem um pouco a circunscrição meramente cooperativa e operacional das coisas. Eu diria que é um debate permanente, e não só da educação, mas da sociedade. É um debate sobre os lugares sociais que os equipamentos ocupam, e sobre a visão que se tem em relação aos dispositivos. Essa é uma discussão permanente. Se você olhar, por exemplo, na medicina, os médicos hoje estão totalmente dependentes das máquinas para fazer diagnósticos. Muitos praticamente se entregam aos diagnósticos que vêm dessas máquinas. Enfim, esse é um problema que se coloca socialmente. É um debate mais amplo, que não diz respeito apenas à educação. Às vezes ficamos com essa ideia, mas o tecnicismo é um fenômeno que transcende a educação e se coloca socialmente. Eu diria que está, logicamente, presente ao debate da educação e da escola.

O curso de licenciatura certamente vem como uma resposta também a esses questionamentos. As pessoas que criaram o curso de Educomunicação são pessoas que vêm, nesses 20 anos, trabalhando nesse sentido de colocar o debate sobre as relações de comunicação e educação num patamar que, obviamente, transcende as questões afeitas às tecnologias, de mediações tecnológicas. Essa perspectiva acompanhou desde a criação da revista: a linha de traduzir as relações entre comunicação e educação num terreno mais ligado à cultura, às relações sociais, aos novos sensórios. É uma tendência que se manteve dentro do Departamento, com os professores que aqui permaneceram, por uma razão ou outra - e que eu creio que continuam olhando a questão por essa perspectiva. É isso que anima a criação do curso de Educomunicação nos termos em que ele está criado. Se olharmos o currículo do curso, veremos que está fortemente ancorado em algo que poderíamos, genericamente, chamar de áreas de formação geral sociabilidade, sociologia, antropologia, não necessariamente com esses títulos, mas espalhadas nesse modo pelo currículo. Então, nós imaginamos que essa nova licenciatura se coloque numa perspectiva maior, mais humanista, mais indagativa sobre a natureza das técnicas, sobre o sentido da inclusão dessas técnicas e desses temas de representação social, como no caso da educação. Acho que isso está, sim, colocado dentro do projeto pedagógico e formativo do curso.

Acho que a revista tem o viés de dialogar com a comunicação, com a educação, de problematizar esses dois termos inclusive - pois a problematização não vem só do lado da comunicação, vinculando o conceito de comunicação imediatamente ao conceito de 
mídia. Mas é também uma problematização que vem do âmbito da educação, já que muitas vezes ela é vista como algo propedêutico, acumulativo, mais dado ao plano do disciplinamento do cidadão. Então, a permanência da atualidade da revista vem através desse traço, que é o traço problematizador de ambos os substantivos "comunicação" e "educação". Ela problematiza isso permanentemente. Nessa perspectiva, o material que a revista fornece é absolutamente atual, já que na medida em que recebemos e encaminhamos os artigos, e damos prosseguimento a esse material, ou solicitamos coisas de colegas, esse debate se reatualiza. É a linha do tempo se reatualizando. Nessa perspectiva, a revista poderia ter ganho um viés de entender que a educação tenha mais a ver com algo regulativo, mas não achamos isso. Mas sim ao conceito de transformação, de mudança. Da mesma forma, a publicação não pode ser algo que diga respeito somente à mídia, a interesses da indústria da comunicação. Ela é um processo verdadeiramente humano, cujo objetivo último deve ser justamente aprofundar os mecanismos interlocutivos e fazer as pessoas avançarem no sentido de viver na sociedade um pouco melhor. Nesse sentido, a comunicação não é apenas um instrumento para alcançar um fim, como muitas vezes a gente vê por aí. A comunicação pode ser um instrumento, mas é parte dos processos humanos, é parte de um jogo amplo - tanto positivo quanto negativo. Portanto, a comunicação tem a ver, nessa perspectiva, com processos formativos.

Acho que esses parâmetros estiveram e estão dentro da revista. Nesse sentido, a revista tem uma historicidade, em que o presente dialoga e atualiza o passado, se transforma, indica novas direções. Eu creio que a revista, enquanto estiver nessa seara, com fôlego para manter a estrutura que tem, terá muito que fazer pela frente.

\section{Professora Ruth Ribas Itacarambi}

\section{Escola de Comunicações e Artes, 26.01.2012}

\section{Como aconteceu o início de sua participação na revista?}

Quem me chamou a participar da revista foi a professora Bacegga. Eu estava fazendo meu doutorado numa interface que era ligada a comunicação, educação e matemática. E eu tinha um site que ainda existe, dentro da Escola do Futuro, que se chama MatemaRede. Nesse processo de comunicação, criamos esse site com os professores da Rede Pública. Em 1999, ainda a internet era muito restrita, a escola pública não tinha muito acesso. E aí, em cima desse trabalho todo, chamei a Bacegga para ler e criticar o meu trabalho. E depois ela compôs também a minha mesa. E a partir desse trabalho, publiquei um artigo na revista e a Bacegga me chamou para montar uma seção de atividades envolvendo os temas transversais. Para fazer isso, ela me mandava já todos os artigos da revista, para que eu pudesse trabalhá-los em cima de uma proposta de transversalidade.

O começo dessa seção na revista coincide com a chegada das orientações curriculares às escolas, ainda no ensino fundamental. E nessas orientações curriculares, um dos grandes temas apontados era a necessidade de fazer a transversalidade. Como um tema como a cidadania pode ser trabalhado? Em geografia, em história, na língua portuguesa... então, a ideia era desenvolver esse tipo de trabalho. Outro objetivo, por exemplo, era trabalhar o meio ambiente, tema muito discutido em sala de aula na época. Então, existe essa coisa de meio ambiente aparecendo nos textos, inclusive na mídia. Começamos a ter muitos artigos discutindo essa questão. Então, direcionamos o trabalho assim. Mas é 
claro que esse trabalho é guiado por uma proposta pedagógica, que é a proposta de Paulo Freire. Poderíamos ter várias propostas pedagógicas - uma mais tecnicista, outra mais construtivista, mas nesse caso preferimos uma proposta dialógica. A idéia das atividades era fazer um paralelo com um diálogo e, além disso, que não fosse algo impositivo. Temos, por exemplo, um cuidado com os verbos: "propomos, orientamos, sugerimos". Deixamos que o professor escolha o momento mais adequado de aplicar as ações em sala de aula.

A revista surge muito tímida do ponto de vista da relação entre comunicação e educação. Num primeiro momento, estava mais centrada em mídias e em seus diferentes suportes. Depois, com o Ismar, trazendo as idéias de Educomunicação, a Baccega e o Citelli, ela começa a tomar esse caminho. Era uma revista do Departamento de Comunicação e passa a ser uma revista da Gestão. Então, ela muda de enfoque. Isso é uma coisa muito própria da ECA, eu acredito - a ênfase em Educomunicação. Na América Latina, se fala muito em comunicação e educação, mas não com essa ênfase, nesse conceito propriamente. É um pouco parecido com o que acontece com a Matemática: temos um movimento chamado Etnomatemática, que é a Matemática sob a perspectiva cultural. E você só tem como centro disso o Brasil. Não existe muito esse movimento fora - embora todo mundo goste de falar sobre educação de alguma forma, traga sugestões. Mas encará-la como um meio de educação, e de conhecimento, ainda é pouco falado e pouco escrito. Quando se vai pesquisar sobre o assunto, os artigos que vêm são da revista. Existem alguns outros referenciais, como a Federal de Pernambuco, que têm algumas pesquisas voltadas a isso. Mas ainda são coisas bastante pontuais.

O que caracteriza a revista é quando se fala da experiência em sala de aula, mas também da rádio, das leituras, das mulheres, dos centros culturais. Tudo isso é educação e comunicação. E essas coisas, lá fora, são pouco faladas. Ou se fala sobre educação, ou sobre comunicação. E é algo de que sentimos falta, precisamos incitar a discussão sobre isso. Por exemplo, como se discute o tema nas diferentes escolas de comunicação? Não existe um tema centralizador, nem na comunicação, nem na educação - o mesmo nas revistas. Por exemplo, se fala sobre "como o jornalista trata a educação", "como escrever sobre educação" - e não sobre o que é efetivamente a Educomunicação, como isso surge nas comunidades. Mas, sim, como eu uso isso como um instrumental. Quando vou cobrir um evento sobre educação, o que tenho que priorizar e observar?

\section{Como levar essa reflexão para dentro da seção que é responsável pela ponte entre a teoria e a prática, a cada edição?}

Para construir a seção, primeiro faço uma leitura dos artigos e, a partir dessa leitura, verifico quais são os artigos que trazem idéias que considero pertinentes para serem discutidas no âmbito da educação. A partir desses artigos, quais tratam da questão do conhecimento como um direito de todos, da importância da democracia, da construção do cidadão e da cidadania, da inclusão social e digital. Existe uma proposta ética ligada à educação, sobre a qual eu faço a escolha. Essa escolha já me dá uma direção. Eu abro para discussão, ou então falo sobre a importância de as pessoas terem idéias diferentes e levanto as questões que acredito pertinentes. Essas questões, em geral, estão mapeadas nos temas transversais - meio ambiente, cidadania, trabalho. Essas coisas que parecem tão antigas, mas cuja discussão parece sempre nova. Sempre, como disse, de acordo com a linha pedagógica proposta por Paulo Freire - enfatizando o diálogo, o professor como orientador, que tem que respeitar a opinião do seu co-ouvinte. Esses conceitos sempre permeiam o artigo. 
Algumas mudanças na educação acontecem de forma um pouco obrigatória. Por exemplo, no início do ano os professores têm que definir o que chamam de projetos, envolvendo diferentes áreas do conhecimento. Ao definir esses projetos, as escolas têm definidos os seus estudos mensais - bacia hidrográficas, fazendas cafeeiras, semana do estudo da ciência, etc. Coisas que toda escola se organiza para preparar - incluindo também a questão dos esportes, etc. Então esses temas acabam sendo cobrados dos professores pela Secretaria de Educação. A preparação é feita com mais ou com menos entusiasmo, dependendo da escola, é claro. Tem a questão cultural, a primavera, festa junina, festa das nações. Quando a Erundina era prefeita e Paulo Freire estava na Secretaria de Educação, as escolas municipais faziam um levantamento das necessidades e dificuldades da região para organizar esse plano de trabalho. Questões como moradia, higiene, etc. Mas houve também leituras incorretas, por exemplo, colocar o tema do saneamento básico em todos os anos de forma igual. Mas na escola sempre há aqueles que encampam a idéia seriamente como os que nem tanto. De qualquer forma, o importante é se conseguir levantar a discussão, e isso esteve presente na escola. Se você tem uma diretoria comprometida, por exemplo, ela própria incentiva e organiza os horários comuns das aulas para que se possa fazer isso - entre geografia e história, por exemplo. O envolvimento do corpo docente também é importante. Conheço grupos que trabalham em lugares distantes, por exemplo, e que poderiam pedir transferência para outras escolas, mas não fazem isso porque o grupo funciona bem e eles não querem quebrar isso. Preferem estar num lugar mais distante, mas desenvolvendo um trabalho onde se sentem bem.

\section{Na sua opinião, qual será a contribuição de uma área consolidada de interface entre a Educação e a Comunicação nesse processo? Acha que o curso de Licenciatura em Educomunicação poderá ser um avanço?}

O curso de licenciatura em Educomunicação é um jeito de levar a preocupação fora dos dois centros da comunicação ou da educação. A própria reflexão do material e das leituras farão com que as pessoas que saírem desse curso, e que forem trabalhar nos meios de comunicação, percebam isso como uma perspectiva. Por exemplo, na área de matemática, temos diversas vertentes de ensino e pesquisa, mas não temos matemática aplicada à educação. E quando os alunos vão lidar com isso, se sentem despreparados, pois falta fundamentação e não sabem onde podem buscá-la. Mas no momento em que você já conhece algumas pessoas, já tem acesso prévio a isso, muda muito, você fica mais tranqüilo. A troca de conhecimentos funciona assim, entre pessoas e organizações. O próprio curso de Gestão já abriu muito para isso.

A minha formação é matemática. E na formação em matemática, somos praticamente excluídos da escrita. A revista trouxe para mim essa atividade do escrever de forma clara, objetiva, de que gosto muito. Eu fui aprendendo a escrever coisas de uma forma mais clara, a partir das exigências da revista. Eu vejo os meus colegas de matemática e eles não escrevem, ou quando escrevem, não se entende nada do que estão falando. Na verdade, todos deveriam se centrar um pouco nessa questão do escrever. A matemática tem a questão de resolução de problemas e a gente acaba se esquecendo do contexto, que é a forma como as coisas acontecem. Ter diferentes referenciais, tanto na área da lingüística como na área da comunicação, é uma coisa muito boa do ponto de vista cultural $-\mathrm{e}$ isso guia inclusive as minhas aulas. Alguns alunos me perguntam se sou professora de matemática ou de história. Mas é importante saber o contexto das coisas, porque uma coisa que é verdade hoje pode não ser verdade amanhã. 
Nos cursos de formação, sempre levo a seguinte questão: quem é a interface mais próxima da área de conhecimento matemática? É a língua natural, no nosso caso, a portuguesa. Porque ela tem a mesma estrutura: você tem que argumentar, levantar hipóteses. É a mesma estrutura. Mesmo quando se trabalha interdisciplinaridade, se diz ao professor de matemática: "você faz os gráficos". Não deve ser assim. Quais são os argumentos, como está organizado o texto? Aí você tem a temática.

\section{Professora Maria Aparecida Baccega \\ Residência da entrevistada - 27.04.2012}

Quais foram os primeiros passos para a criação da revista, e qual sua relação, nesse início, com o curso Gestão da Comunicação?

A relação da revista com o Curso de Gestão fica evidente desde o primeiro momento, uma vez que no Curso há disciplinas, núcleos que tratam de comunicação e educação. Naquele momento do Departamento, o prof. Ismar tinha uma história de trabalho com a educação na comunidade, ligado a ONGs, e eu sempre trabalhei com a educação formal - fui professora desde fazenda até da USP. Fui diretora de escola de 1 grau. Enfim, sempre achei importante o processo educacional formal nas escolas. Sempre estive dentro do formal. E, mesmo em priscas eras, realizava muitos trabalhos envolvendo equipamentos que existiam fora da escola.

A mídia não tinha ainda a força que tem hoje, apenas começava a ter força - porque fui diretora em 1966 e, durante esse tempo, pude fazer as coisas de forma a que beneficiassem, pelo menos do meu ponto de vista, um conjunto grande de alunos. Nós trabalhávamos não só com a questão da educação, da comunicação e da mídia, que começava a ter força, mas também com todos os equipamentos que havia fora da escola e na comunidade - sindicatos, igrejas independente de crença. Sempre achei absolutamente indispensável que não houvesse barreira entre a escola e o que acontecia no mundo. Sempre achei que o professor tinha que estar preparado pra isso. Enfim, nesse caminho, acabamos por criar o curso de Gestão e, nesse curso, já colocamos as disciplinas Comunicação e Educação, dadas pelo Ismar.

Eu pretendia fazer duas revistas: uma de Comunicação e Educação e outra de pósgraduação stricto sensu. Fizemos um concurso para a capa da revista, dirigido aos alunos da universidade, mas na verdade quem mais apareceu foram alunos da FAU e da ECA. E o primeiro lugar era para capa da revista de pós-graduação stricto sensu. Eu me lembro que o pagamento do prêmio era em URV, que era como dólar, convertida de acordo com o dia. E o segundo lugar era para a revista Comunicação e Educação. Eu, que era chefe do departamento nessa época, me pus a campo para conseguir uma das duas revistas. Tinha vários amigos que estavam na editora Moderna e também na editora Ática. Na Moderna, conseguimos interessar os donos e, como ela sempre trabalhou muito com educação e material para professores, ela gostou da idéia e fez a revista. Inclusive, eles disseram que iriam fazer porque confiavam que eu iria conseguir fazer uma revista de texto acessível aos professores, que era o interesse deles. Fizemos uma experiência de número zero, eles gostaram e fomos em frente. Ficamos com eles até o número 16. Batalhei muito, fazia a revista praticamente sozinha. Não tínhamos secretária, editora, nada disso. Nem tínhamos dinheiro para isso. Claro, o material passava por pareceristas, mas só isso. O resto era a gente mesmo que fazia revisão e 
tudo mais. Depois foi melhorando - conseguimos colocar uma secretária, depois uma orientada minha que hoje é professora de vocês, a Roseli Figaro, veio ajudar. E ajudou muito, fez a revista praticamente sozinha durante algum tempo em que eu estava envolvida em outras pesquisas. Enfim, a revista foi muito sofrida, muito sem condições, mas de muito êxito.

O que quero deixar registrado é que nesse momento ninguém falava em Comunicação e Educação. Que, aliás, é o nome que eu prefiro. O objetivo de Comunicação e Educação é exatamente que você veja a Educação a partir do campo da Comunicação, que é um campo mais aberto, e Educomunicação não dá essa idéia. Nós ficamos então na editora Moderna até o número 16. Uma revista que dá prestígio, mas não dá dinheiro - e a nossa não dá, nunca daria - é a primeira coisa que se corta em qualquer crise. E havia uma pequena crise na Moderna, quando decidiram cortar a revista. Mas eles mesmos se movimentaram e conseguiram transferir a revista para a Segmento. Ela ficou quatro ou cinco números na Segmento e então ficamos novamente pagãos. Fomos depois para outra editora. Ficamos lá alguns números até que houve também um problema econômico e eles cancelaram a revista. Era um momento muito difícil de dinheiro no Brasil, entre as editoras. Aí a Cristina Costa conseguiu o contato das Paulinas, fomos até lá e explicamos, apresentamos a proposta da revista. Passamos então para a Paulinas. Fiquei na revista ainda até 2004, como editora. Me aposentei em 2003, e passei o cargo à Cristina. Agora estão ela e o Adilson Citelli, o que acho ótimo.

\section{Quais as principais mudanças que puderam ser notadas na forma como se vê a área de comunicação e educação ao longo dos anos?}

Ao longo dos anos, vi mudança no sentido de que alguns pontos do Brasil, agora, começam a falar sobre comunicação e educação. Nesse instante, por exemplo, está aparecendo um estudo sobre o assunto na Federal de Santa Maria. Já há uns 5 anos existe algo também em Santa Catarina, que é onde está a Ademilde Sartori, uma gente muito boa. Foram pessoas que vieram fazer pós-graduação aqui e fizeram essa opção. A mudança que eu vi, realmente, é que as pessoas começaram a saber, primeiro, que a área existe. Porque até então, a coisa funcionava assim: "Eu sou contra a comunicação na sala de aula e ponto." Não havia discussão. Agora não, a pessoa pode ser contra - e acredito até que, conscientemente ou não, eles são - mas são capazes pelo menos de abrir um pouco o ouvido e existem condições de diálogo. As pessoas aparecem, já existem livros sobre o assunto. Ou seja, começamos a ter uma certa estrutura científica para discutir o tema, que não existia antes. Acho que conseguimos abrir alguma coisa nesse país. E a revista foi fundamental, foi ela que levou isso. A cada congresso, levávamos a revista, apresentávamos, fazíamos palestras, discutíamos com as pessoas. Fomos bastante pioneiros, missionários mesmo, e acho que fizemos bem.

A receita editorial da revista, hoje, não é exatamente aquela receita original. Não sei se estou ultrapassada, mas ainda prefiro a original. Se você observar, entre os primeiros números da revista, está publicado o artigo de um amigo meu, publicitário, que tinha feito a publicidade da Carlton. E foi publicado, interessava contar como era feito, como era o outro lado. E hoje, se isso fosse feito numa revista de educação, nossa. Mas enfim, a reação à receita editorial não foi simples. No começo, inclusive, quando começa a qualificação da revista, o Qualis, há uma certa reticência com relação à nossa revista até porque a gente não coloca apenas artigos acadêmicos e pesquisas em andamento, mas colocamos experiências de professores, por exemplo. Mas agora acho que já não 
acontece isso - ela se implantou, é assim e ponto final. Não sinto mais esse problema. Eu não estou na revista, mas estou no campo, e não tenho ouvido mais.

Nosso interesse sempre foi atingir a Rede. Tentamos de todo modo falar como Secretário de Educação, com o Ministro da Educação, demos coleções da revista até aquele momento para essas autoridades. E não conseguimos sucesso, é impressionante. A gente não sabia, e eu não sei até hoje, conversar com as autoridades. Não sei trocar. Eu tenho um produto bom, excelente para a Rede, e é isso. Você está ocupando um posto importante e, se conhecer educação, sabe que isso é importante. Então... não tenho muito que dizer. E talvez essa negociação não tenha sido adequadamente feita, nos moldes em que costuma ser feita no Brasil. Nós nunca conseguimos, o que é bem lamentável.

Então, a revista começou a ser conhecida e o pessoal, por exemplo, da área de educação, avaliou a revista e nos deram uma avaliação maravilhosa, e inclusive publicamos um editorial sobre isso. Enfim, as coisas começam a acontecer de uma forma mais adequada para nós, do ponto de vista acadêmico. Passamos a ser conhecidos, respeitamos, com muito esforço, embora a qualidade da revista sempre tenha sido ótima desde o primeiro número. Mas do ponto de vista de que os professores de todo o Estado de São Paulo recebessem a revista, isso nós não conseguimos.

Existem várias opções profissionais que se ligam à revista. Aliás, a revista é até mesmo uma maneira das pessoas procurarem o Departamento. O pessoal de educação está presente e o de comunicação também. Eu tenho visto em muitas dissertações e teses, de cuja banca eu participo, na Bibliografia a revista. Isso me deixa muito contente. E no campo acadêmico também, existe muita aquisição, muita leitura. Não sei se vende, se o pessoal compra, ou se tem acesso na biblioteca, enfim. De qualquer modo, o importante é que é lido. Acho que estar na internet não significa vender menos, por exemplo. Pelo contrário, tenho a impressão de que estar na internet é uma publicidade para a revista. As pessoas ficam conhecendo e, se realmente se interessarem, começam a aguardar a revista.

As pessoas que lêem Comunicação \& Educação ainda são pessoas que estão na fase de ler papel. Ninguém foi alfabetizado na internet. Por exemplo, eu sou capaz de entrar no site da revista, mas não leio um artigo inteiro com a atenção necessária na internet. A gente, a minha geração, não foi alfabetizada desse modo. Não temos esse contato com a tela que os mais jovens têm. Por isso, acho que sempre haverá lugar para a revista impressa. Nesse sentido, pode ser que o site funcione como uma peça publicitária. Mas não tenho dados.

Acho que, na medida em que o campo Comunicação e Educação foi se implantando, você vai encontrar na revista repercussões nesse campo, portanto, da própria revista, o que é um diferencial desse campo. Acho que essa é uma das funções mais importantes da revista, entre outras. Nós sempre recebemos muitos artigos, sempre tivemos a gaveta cheia. Nunca tivemos falta de artigos, só excesso. Então passaram a vir mais artigos acadêmicos, enquanto tínhamos que ir atrás de outras seções, como por exemplo, a seção Experiência. A experiência existia, mas quando se pedia para o professor escrever, ele não escrevia. Mudou ao longo do tempo, no sentido de ter mais artigos e mais acadêmicos, etc. 
Eu acho que a revista merece todos os elogios do mundo, todas as palmas, coroas. Porque ela realmente foi a mais forte responsável pela implantação dos estudos de comunicação e educação no Brasil. Nós avançamos muito nesse campo. Ainda falta muito, o Brasil sempre tem e sempre falta. Mas acho que a revista dá esse enorme orgulho para nós, para o curso de gestão. Inclusive, essa nova graduação do Departamento advém dos resultados dessa revista. A gente plantou e ficou, com qualidade, com originalidade. E saiu esse curso, que eu gostaria muito que vingasse por bastante tempo, e as pessoas começassem a entender do que se trata.

A revista se chama "Comunicação e Educação" porque esse é um campo que tem que formular teorias a respeito de produção de sentido. A produção de sentido tem um pé em cada um desses dois lugares e continuo defendendo, porque o mais importante é ver a comunicação a partir da educação, e não o contrário. Há um certo ranço no pessoal da educação, que não perdem. Compete a nós, apesar desse ranço, fazer com que essas questões de comunicação e educação entrem na escola, ao invés de serem discutidas no recreio ou em outros lugares, porque elas são discutidas.

É preciso ter reflexão, produzir reflexão sobre o campo Comunicação e Educação. O campo não se restringe a ter atividades comunicacionais nas escolas, ou seja, fazer um jornal. É muito além disso. Isso pode ser um resultado desse muito além, que também é algo que está faltando bastante. Pensar o que é o campo, que tipo de proposta teórica temos para ele. Deve haver uma contextualização teórica do fazer. Não é o fazer pelo fazer, senão você fica reproduzindo aquilo que já está. Esse é o grande medo - endeusar ainda mais os meios do jeito que estão aí. Não temos que esquecer a televisão, pelo contrário, temos mais é que ver televisão, discutir, pensar - mas temos que ter propostas para mudar. Ninguém em sã consciência vai achar que estamos no melhor dos mundos. 


\section{Anexo 3 - Reproduções de capas de Comunicação \& Educação (1994 a 2011)}

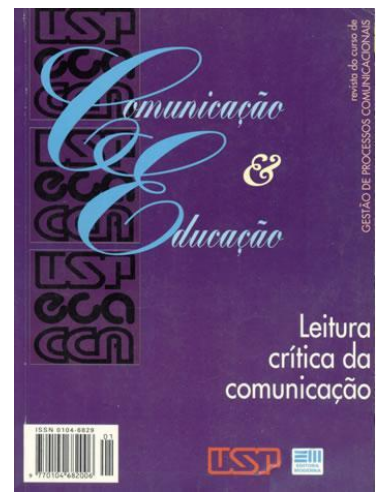

$n^{\circ} 1$, ano $I$,

setembro/dezembro 1994
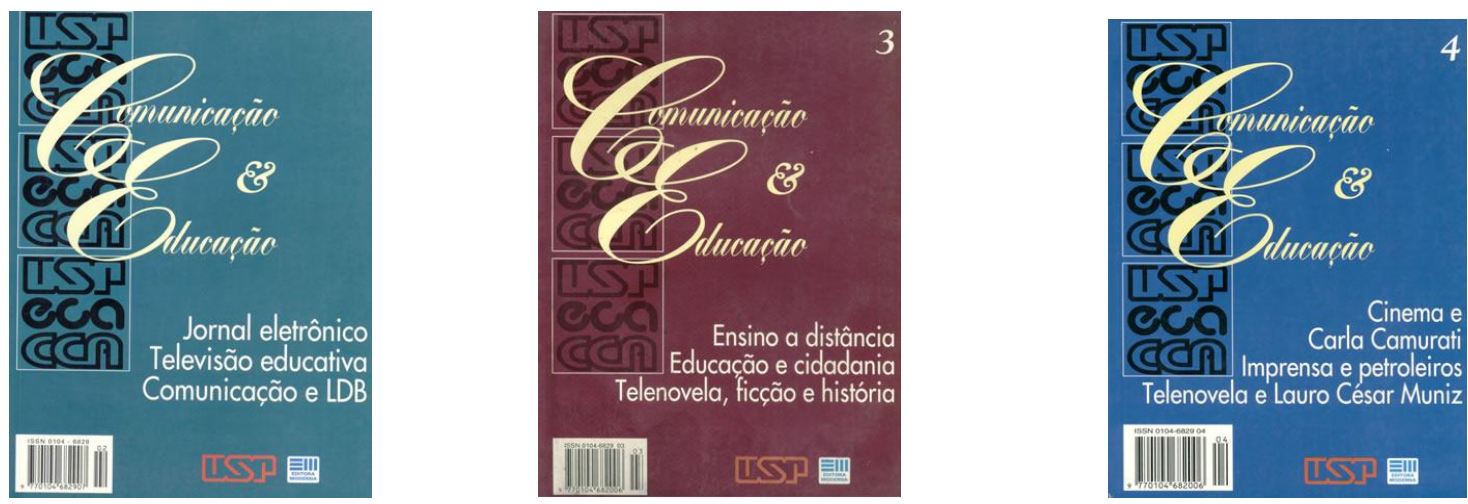

$n^{\circ} 2$, ano I, janeiro/abril 1995;

$n^{\circ} 3$, ano I, maio/agosto 1995;

$n^{\circ}$ 4, ano II, setembro/dezembro 1995
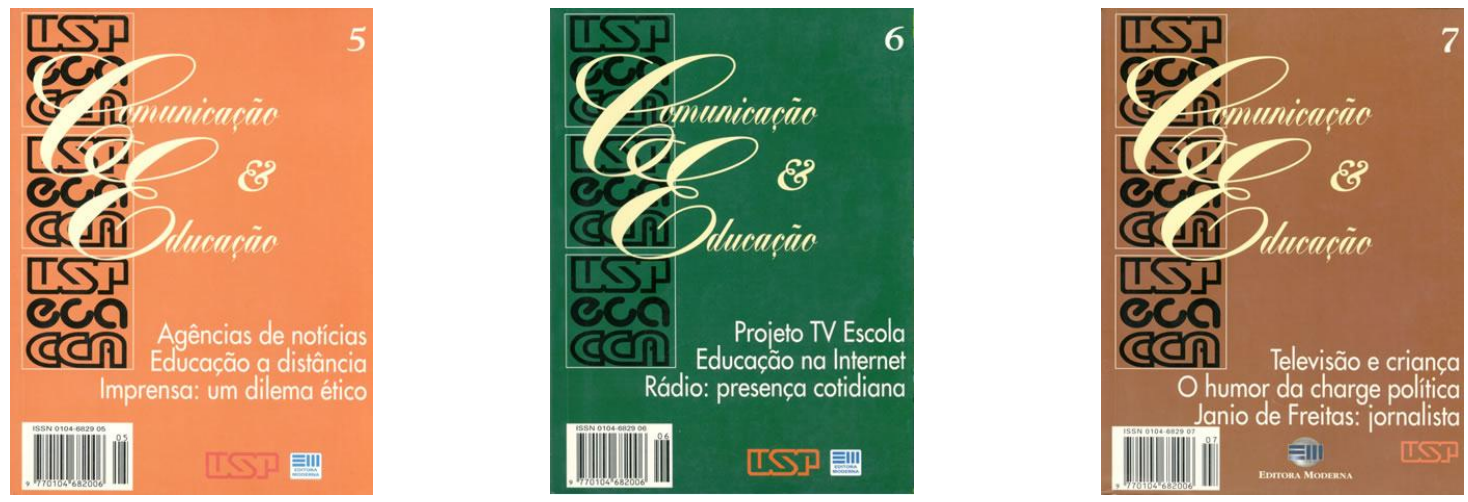

$n^{\circ} 5$, ano II, janeiro/abril 1996; $\quad n^{\circ}$ 6, ano II, maio/agosto 1996; $\quad n^{\circ}$ 7, ano III, setembro/dezembro 1996 

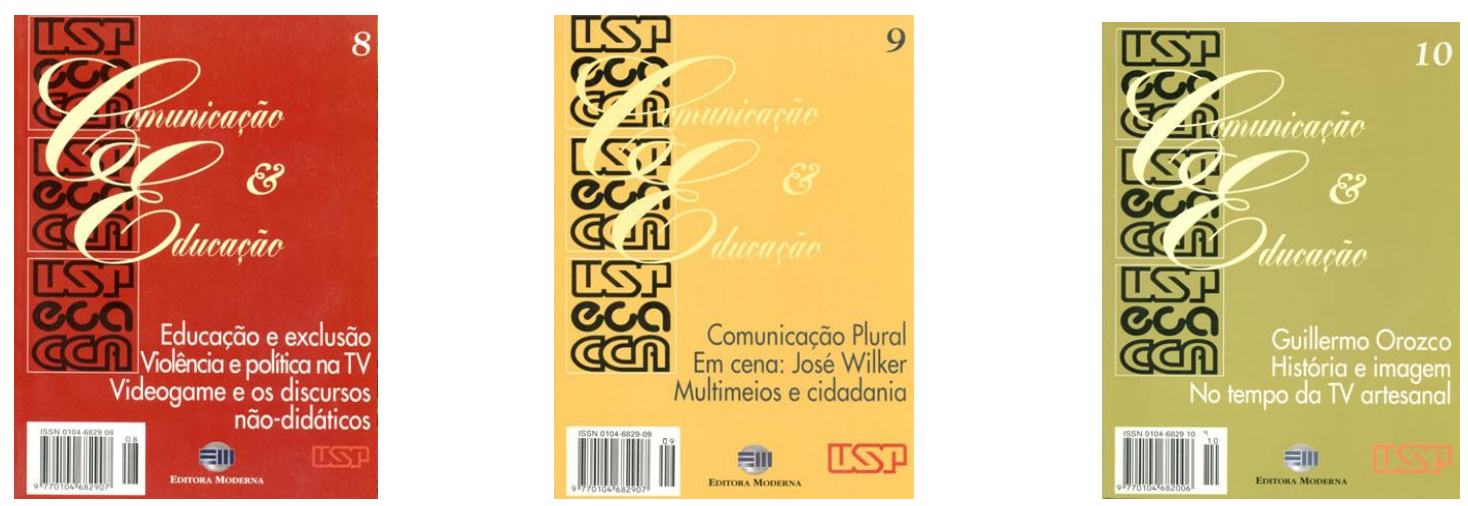

$n^{\circ} 8$, ano III, janeiro/abril 1997; $n^{\circ} 9$, ano III, maio/agosto 1997; $n^{\circ} 10$, ano IV, setembro/dezembro 1997
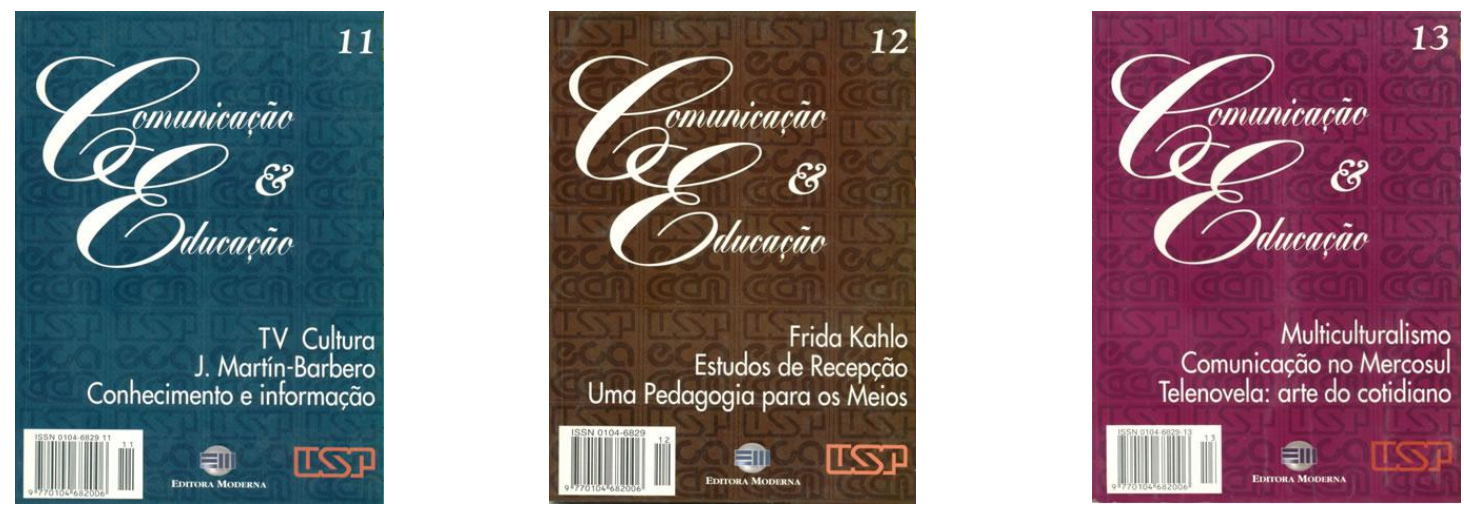

$n^{\circ} 11$, ano IV, janeiro/abril 1998; $n^{\circ} 12$, ano IV, maio/agosto 1998; $n^{\circ} 13$, ano V, setembro/dezembro 1998
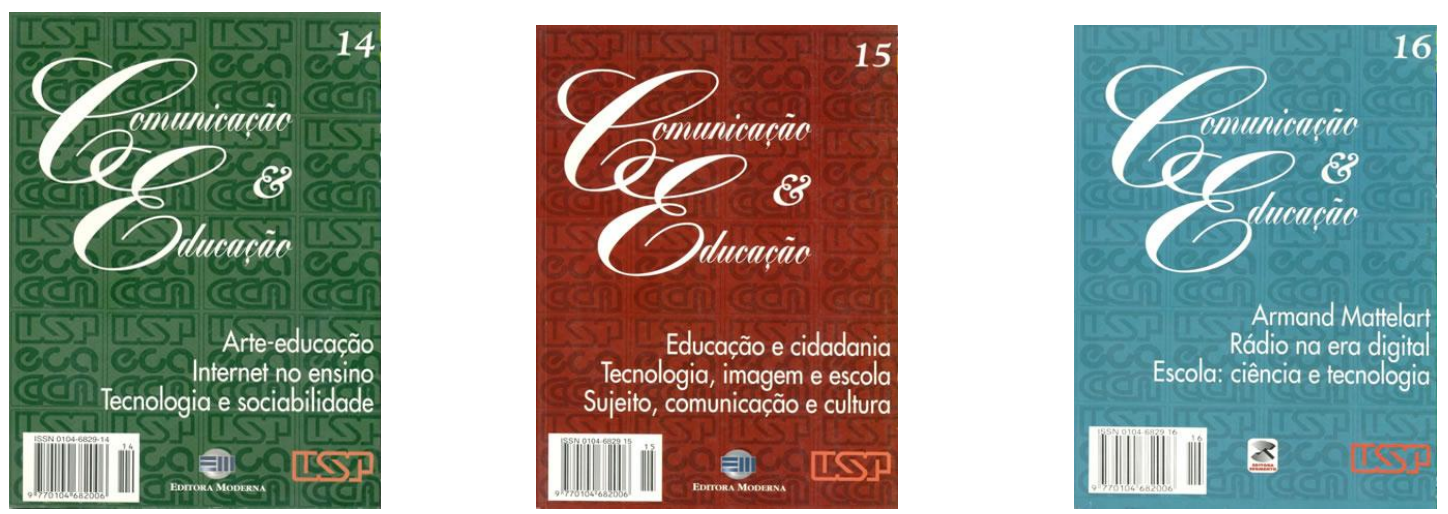

$n^{\circ} 14$, ano V, janeiro/abril 1999; $n^{\circ} 15$, ano V, maio/agosto 1999; $n^{\circ} 16$, ano VI, setembro/dezembro 1999 

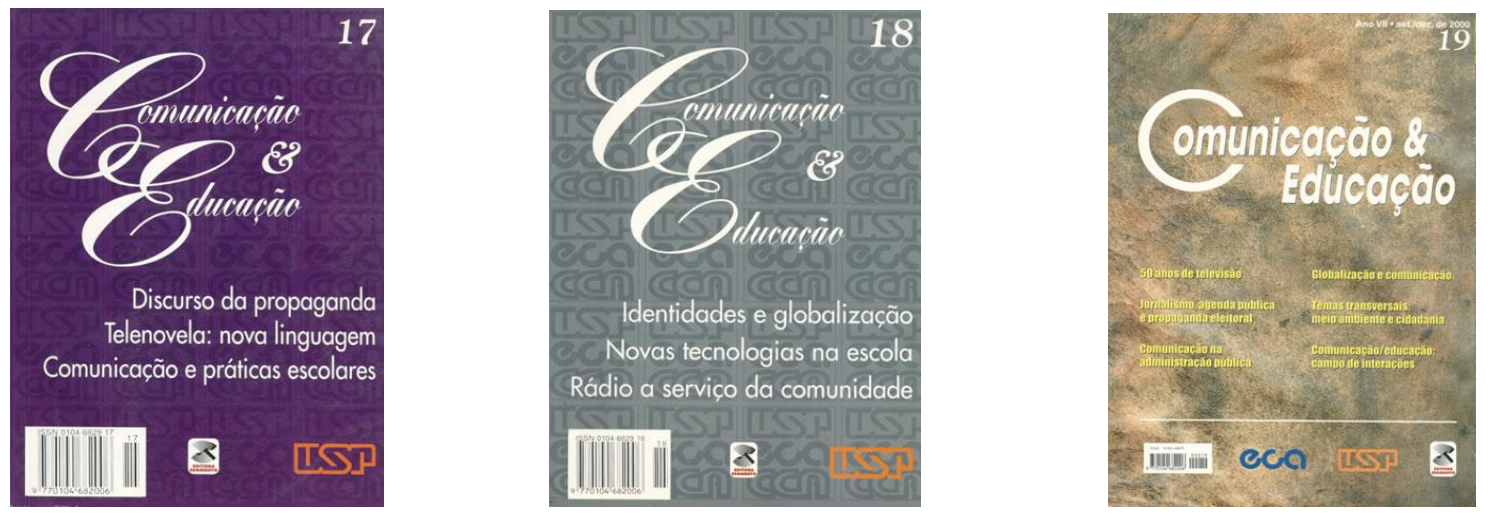

$n^{\circ} 17$, ano VI, janeiro/abril 2000; $n^{\circ} 18$, ano VI, maio/agosto 2000;

$n^{\circ} 19$, ano VII, setembro/dezembro 2000
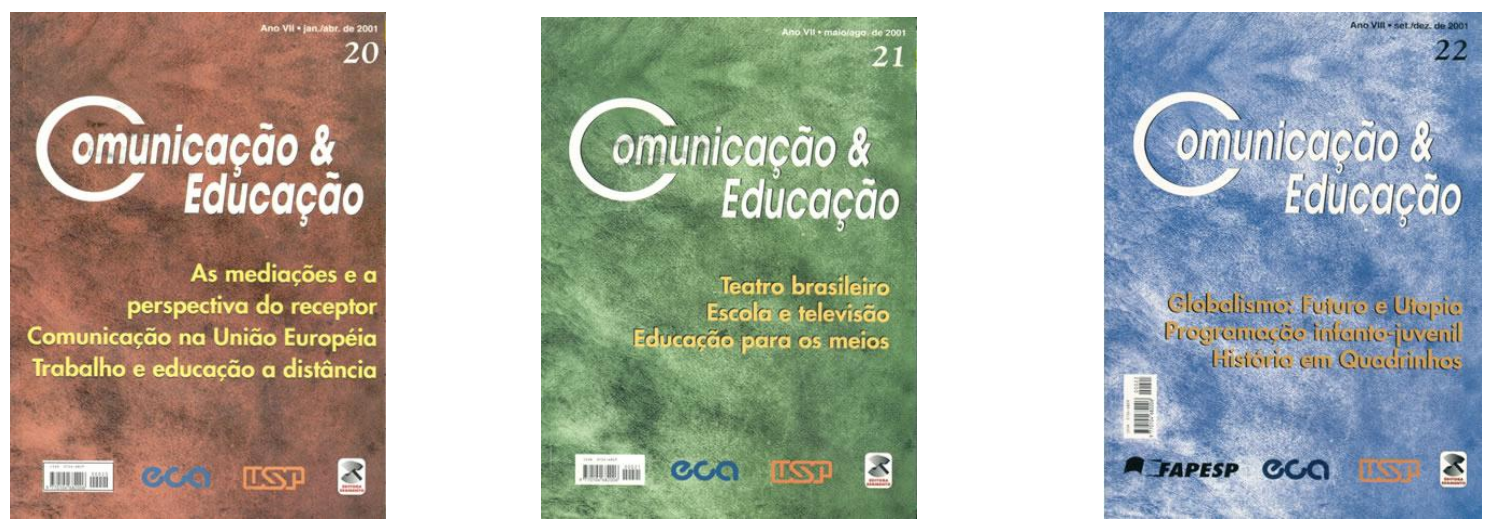

$n^{\circ} 20$, ano VII, janeiro/abril 2001; $\quad n^{\circ} 21$, ano VII, maio/agosto 2001; $n^{\circ} 22$, ano VIII, setembro/dezembro 2001
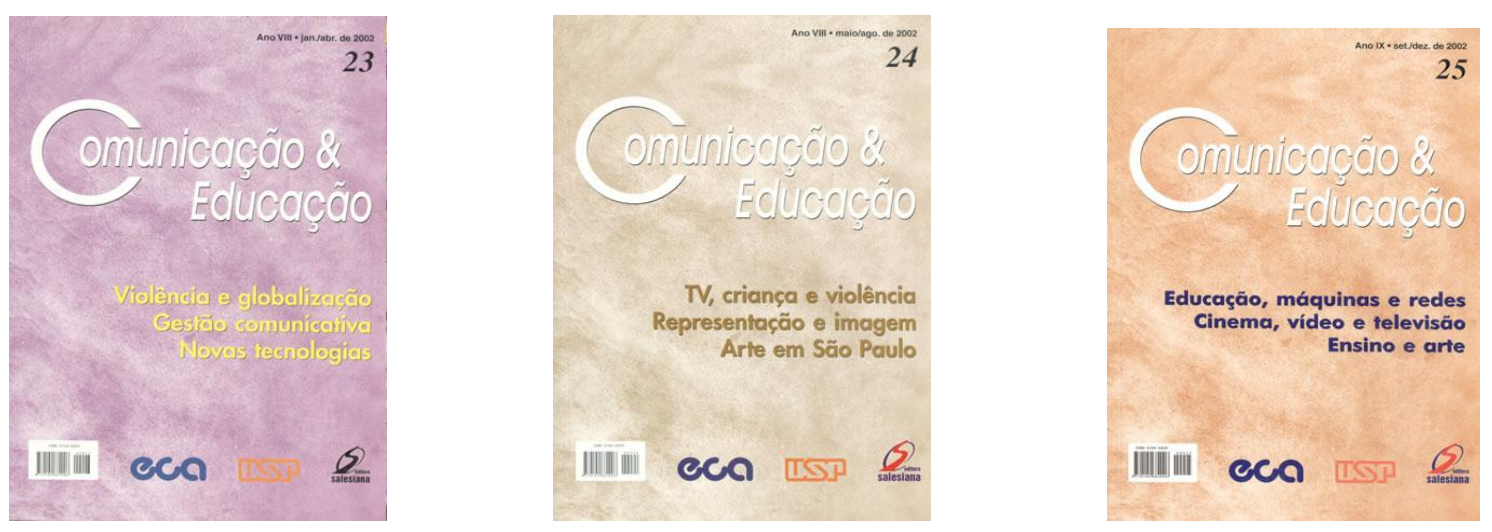

$n^{\circ} 23$, ano VIII, janeiro/abril 2002; $n^{\circ} 24$, ano VIII, maio/agosto 2002;

$n^{\circ} 25$, ano IX, setembro/dezembro 2002 

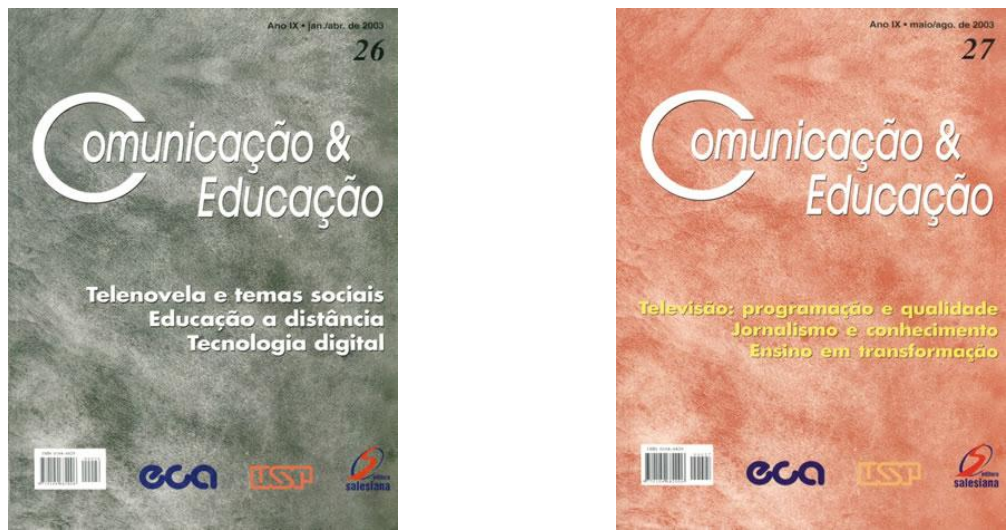

$n^{\circ} 26$, ano IX, janeiro/abril 2003; $n^{\circ} 27$, ano IX, maio/agosto 2003
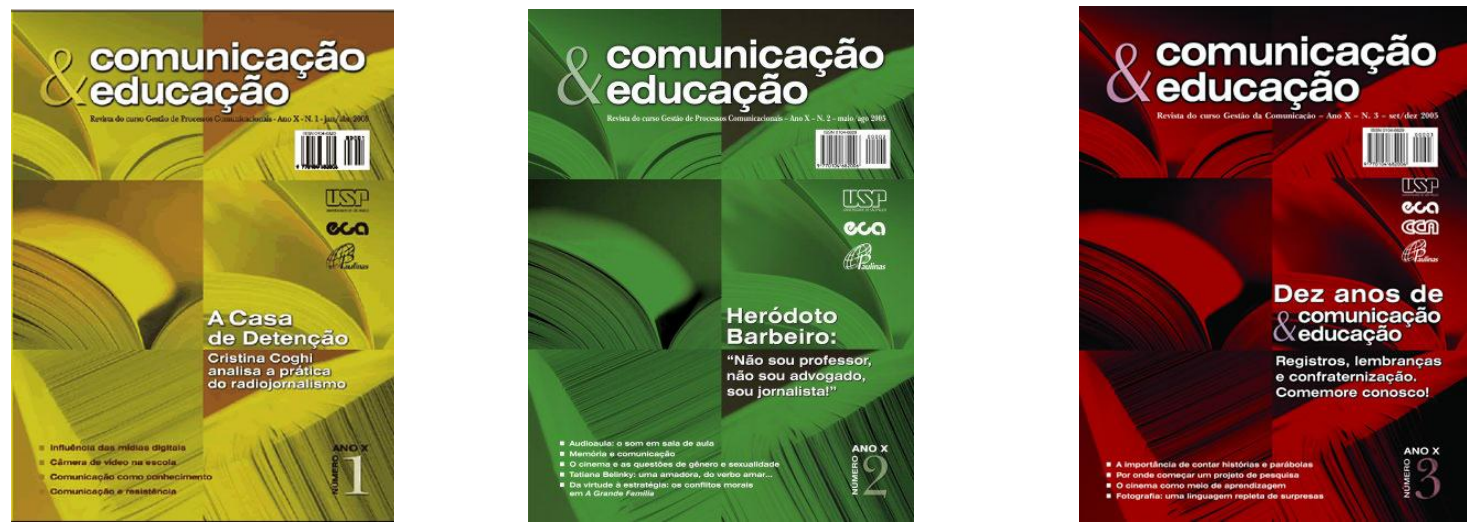

$n^{\circ} 1$, ano $X$, janeiro/abril 2005;

$n^{\circ} 2$, ano $X$, maio/agosto 2005; $\quad n^{\circ} 3$, ano X, setembro/dezembro 2005
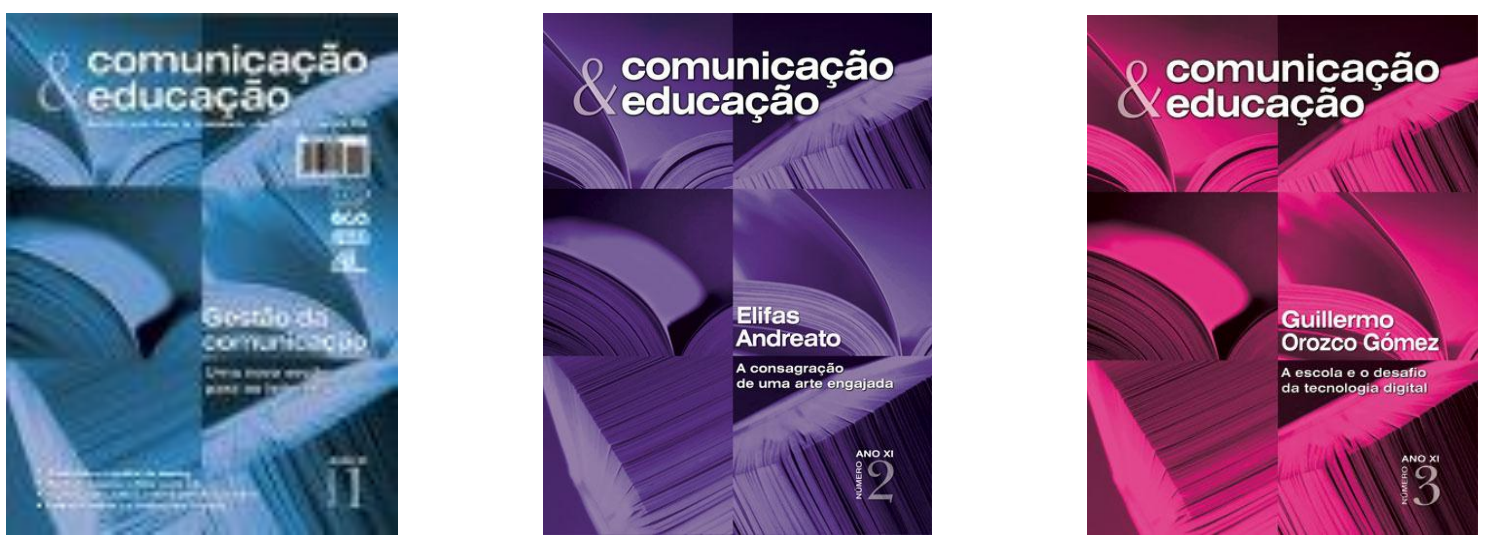

$n^{\circ} 1$, ano XI, janeiro/abril 2006; $n^{\circ} 2$, ano XI, maio/agosto 2006;

$n^{\circ} 3$, ano XI, setembro/dezembro 2006 

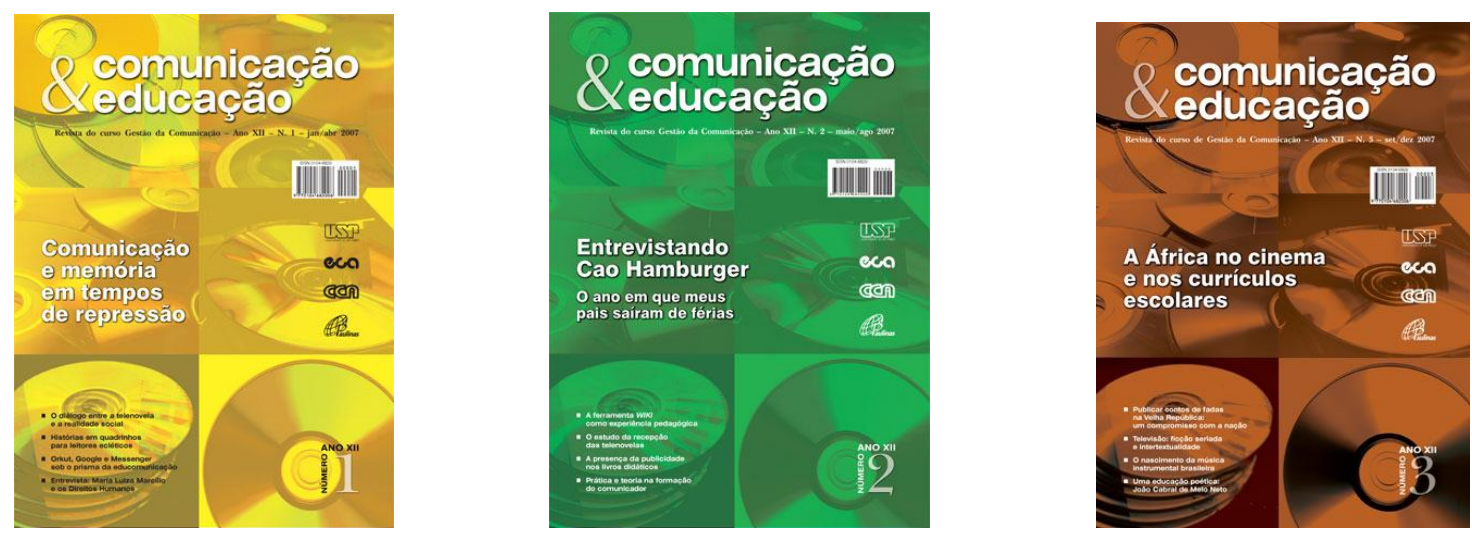

$n^{\circ} 1$, ano XII, janeiro/abril 2007; $n^{\circ} 2$, ano XII, maio/agosto 2007; $n^{\circ} 3$, ano XII, setembro/dezembro 2007
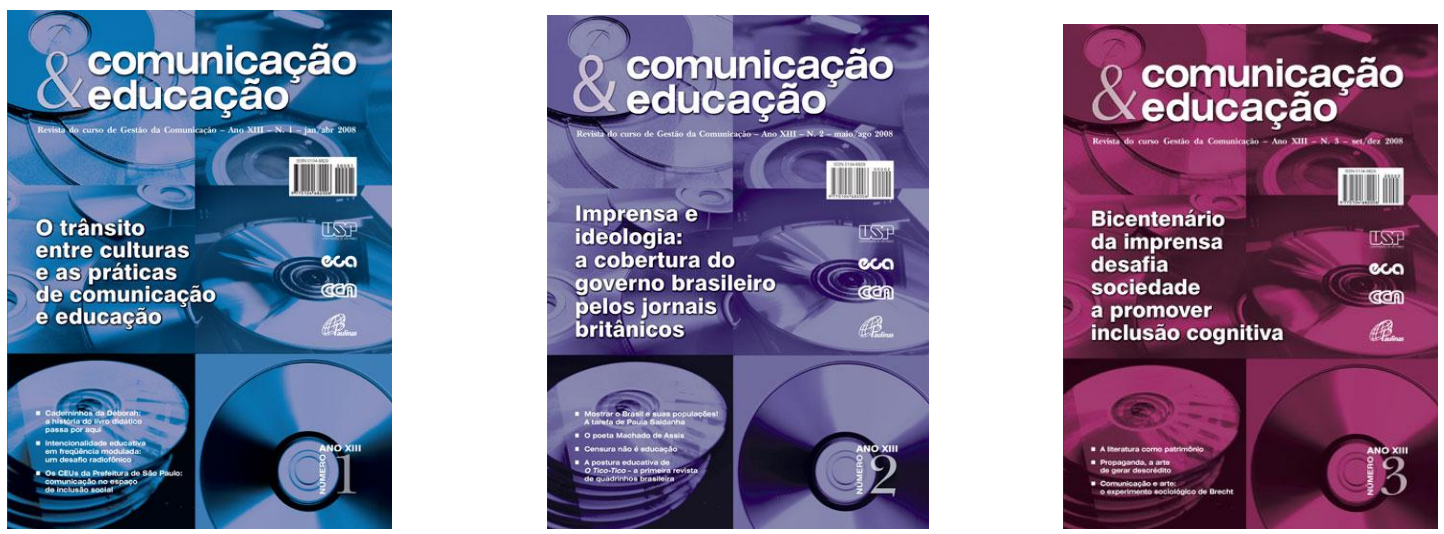

$n^{\circ} 1$, ano XIII, janeiro/abril 2008; $n^{\circ} 2$, ano XIII, maio/agosto 2008;

$n^{\circ} 3$, ano XIII, setembro/dezembro 2008
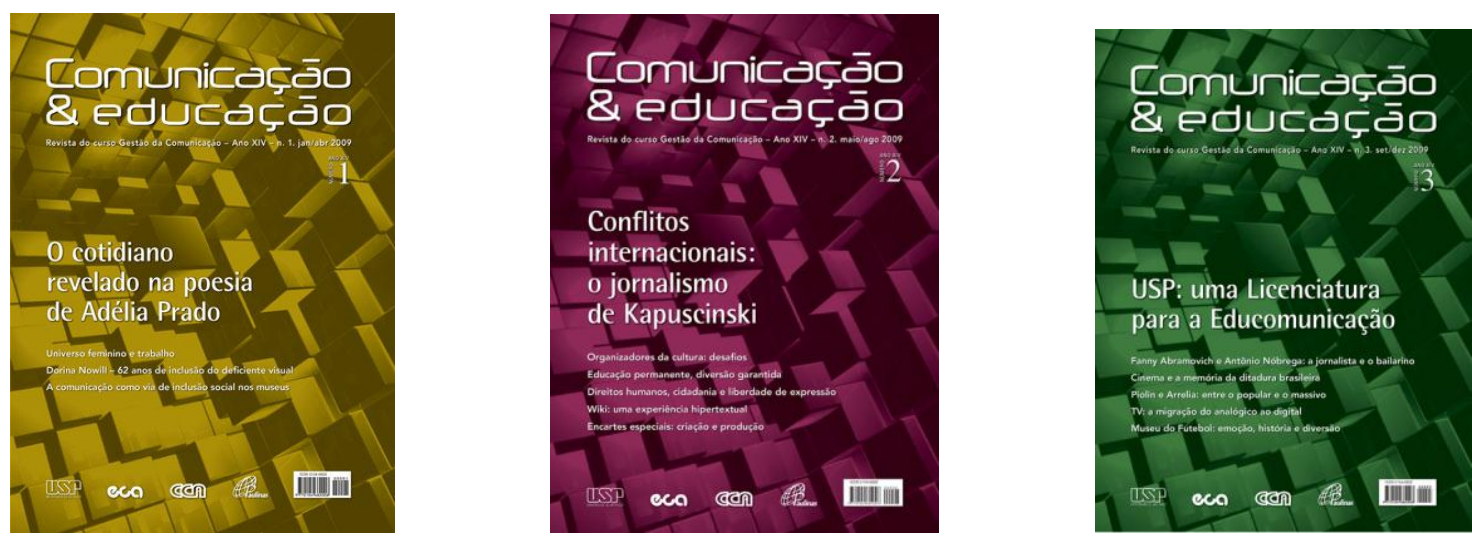

$n^{\circ} 1$, ano XIV, janeiro/abril 2009; $n^{\circ} 2$, ano XIV, maio/agosto 2009;

$n^{\circ}$, ano XIV, setembro/dezembro 2009 

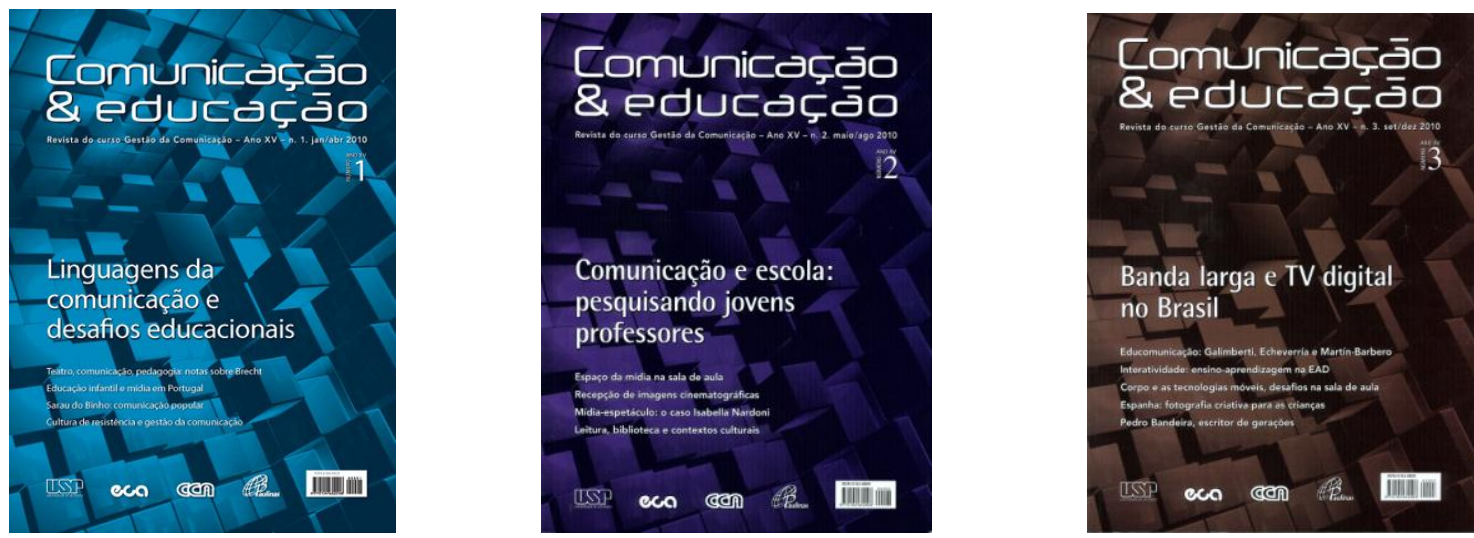

$n^{\circ} 1$, ano $X V$, janeiro/abril 2010; $n^{\circ} 2$, ano $X V$, maio/agosto $2010 ; n^{\circ} 3$, ano $X V$, setembro/dezembro 2010
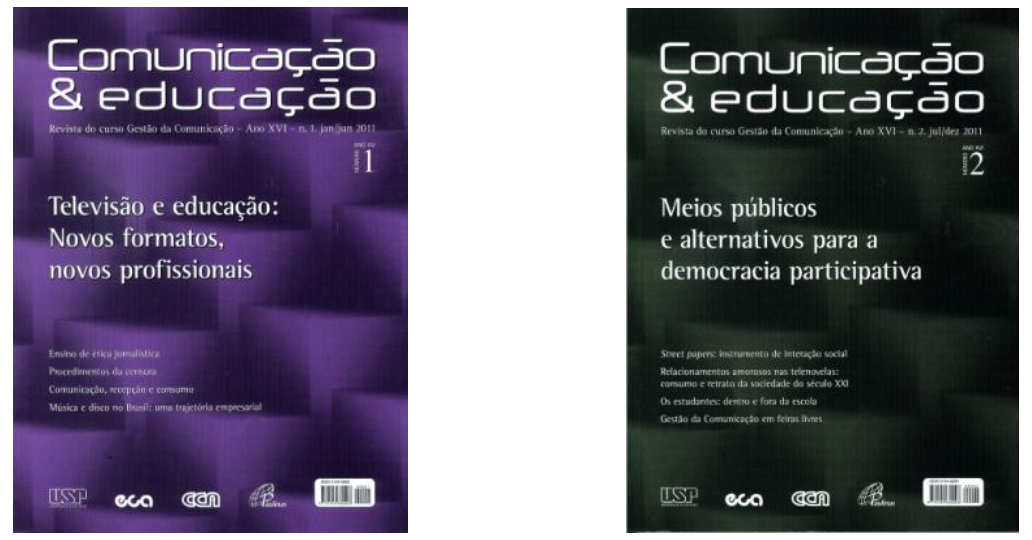

$n^{\circ} 1$, ano XVI, janeiro/junho 2011; $\quad n^{\circ} 2$, ano XVI, julho/dezembro 2011 


\section{Anexo 4 - Ocorrência de temas por seção da revista}

(de acordo com autores e palavras-chave)

$1994-2003$

\section{$\underline{\text { Artigos Nacionais }}$}

Autores (e número de ocorrências)

ALMEIDA, Adriana Mortara

FRANCO, Marília (2)

ALMEIDA, Amélia Leite de

ALVES, Luís Roberto (2)

ALVES, Lynn Rosalina Gama

ANDRADE, Roberta Manuela Barros de

ARAÚJO, Denise Lino de

BALOGH, Anna Maria

BARBIERI, Marisa Ramos

BARBOSA, Ana Mae

BARREIRO, Aguida C. M. e Daniel

Luís

BARROS FILHO, Clóvis de (2)

BARROS, Armando Martins de

BELLONI, Maria Luiza

BERLINK, Aldete Büchler Zorrón

BLOIS, Marlene M.

BORTOLOZZI, Arlêude

BOSI, Alfredo

CAGNIN, Antônio Luís (2)

CAÑIZAL, Eduardo Peñuela

CAPELLINI, Zeca

CARNEIRO, Vânia Lúcia Quintão

CARVALHO, Célia Pezzolo de (2)

CHAVES, Eduardo O. C.

CHRISTOFOLETTI, Rogério

CITELLI, Adílson Odair (2)

CORTELAZZO, Iolanda Bueno de

Camargo

COSTA, Luciano Martins (2)

COSTA, Maria Cristina Castilho

DAVINO, André

DAVINO, Gláucia

DEL BIANCO, Nélia R.

DUARTE, Fábio

ELIAS, Maria de Fátima Faila

FARIA, Maria Alice

FERNANDES, Nanci

FERREIRA, Waldir

FÍGARO, Roseli

FONSECA, Maria Tereza Azevedo da

GOSCIOLA, Vicente

GUIMARÃES, Iara Vieira

GUIMARÃES, Margaret

HAEFFNER, Leris S. B.

HOINEFF, Nelson

IANNI, Octávio

IJIUM, Jorge Kanehide

INCONTRI, Dora

KARAM, Francisco José Castilhos

KOBASHI, Nair Yumiko

KOSSOY, Boris

KRUGLI, Ilo

LARA, Marilda Lopes Ginez de

LEANDRO, Anita

LIMA, Maria de Fátima Monte

LIMA, Solange Martins Couceiro de

LOBATO, Elvira

LOPES, Maria Immacolata Vassallo de

(2)

LUKIANCHUKI, Cláudia

MACHADO, Arlindo

MAGALHÃES, Cláudio

MAGALHÃES, Márcio Tadeu

MAGNO, Maria Ignês Carlos

MARCOVITCH, Jacques

MARQUES, Luís Henrique

MARES GUIA NETO, Walfrido

Silvino dos

MARQUES, Isabel A.

MATTOS, Heloísa

MATTOS, José Augusto

MEDITSCH, Eduardo

MELO, José Marques de

MENDONÇA, Mary Enice Ramalho de

MIRANDA, Maria Inês

MORAES, A. P. Quartim

MORAIS, Gelcivânia Mota Silva

MORÁN, José Manuel (2)

MOREIRA, Sônia Virgínia

MORETTIN, Eduardo Victorio 
MOSTAFA, Solange Puntel

MOTTER, Maria Lourdes

MUNGIOLI, Maria Cristina Palma

NÊUMANE, José

NOGUEIRA, Luís Lindolfo

ORTIZ, Renato

PACHECO, Elza Dias

PAIVA, Claudio Cardoso de

PALACIOS, Marcos

PIERRO, Maria Clara Di

PINTO, Virgílio B. Noya

PORTO, Mauro Pereira

PORTO, Tânia Maria Esperon (2)

PRADO JÚNIOR, Antônio de Pádua

PRETTO, Nelson

PUPO, Maria Lúcia de Souza Barros

QUADROS, Paulo da Silva

REIS JÚNIOR, Antônio

RIFIOTIS, Theophilos

RONDELLI, Elisabeth

ROVAI, Marta Gouveia de Oliveira

RUBIM, Antônio Albino Canelas

RUBIM, Renato

Temáticas (e número de ocorrências)

ação educativa (2)

adolescentes

agências de notícias

agenda setting (2)

agente de mudança

alfabetização

aluno

alunos

ambiente escolar

Ângelo Agostini (2)

apreciação

aprendizado

arte (2)

arte-educação (3)

arte-Educação Baseada em Disciplinas

artes Plásticas

atividade lúdica

audiência

audiovisual (2)

automação

autores

banco de dados

Barroco brasileiro

Batman

Bernard Charlot
SANGIORGI, Osvaldo

SANTOS, Edméa Oliveira dos

SANTOS, Maria Salett Tauk

SANTOS, Roberto Elísio dos (2)

SETTON, Maria da Graça Jacintho

SILVA, Dilma de Melo

SILVA, Marisa Tsubouchi da

SILVA FILHO, Genésio Zeferino da

SOARES, Ismar de Oliveira (7)

SOUZA, Herbert de

TÁLAMO, Maria de Fátima Gonçalves

M. (2)

TONDATO, Márcia Perencin

TORIELLO, Luciano Biagio

TOURINHO, Irene (2)

TREVISANI, Maria de Lourdes

Longhini

VAZ, Élida

VIEIRA, Alice

VIEIRA, Evaldo Amaro

WAINER, Júlio

YAMAMOTO, Oswaldo $\mathrm{H}$.

bibliografia

bibliometria

biblioteca

Brasil

campo cientifico

canais

canal público

candidato (2)

capitalismo (2)

caricatura

carta dos leitores

cartum

Castelo Rá-Tim-Bum

CD-Rom

censura (2)

centros de ensino

chanchada

ciberespaço (3)

cibernética

cidadania (9)

ciência

cinema (3)

cinema e educação

cinema educativo (2)

cinema Novo 
cinemateca

classificação decimal universal

competências e habilidades

complexidade do conhecimento

composição musical

computador

comunicação dirigida

comunicação e educação

comunicação interativa

Comunicação intercultural

comunicação política

comunicação (4)

comunicação/educação

comunidade virtual

comunidade (2)

conhecimento, (4)

consciência cultural

conscritos (2)

constituição

contemporaneidade

conto

contos populares

controle de informação

corte

correspondente estrangeiro

cotidiano (2)

criança

criatividade,

crítica, (2)

cultura letrada

Cultura de massa

cultura mega-regional

cultura midiática

cultura narrativa

cultura negra

cultura popular

cultura (4)

currículo (3)

dança

DCNEM

democracia (4)

desenho animado

Diabo Coxo

diálogo

didática

didático

direito à informação (2)

direitos sociais

discurso didático

discurso não-didático discursos não-didáticos

diversidade cultural

documentação

documento

ecumenismo

educação (18)

educação a distância (5)

educação ambiental (2)

educação Artística

educação especial

educação não-formal

educação para a comunicação (2)

educação para os meios

educação Patrimonial

educação tecnológica

educador

Educomunicação (3)

eleições

eleitor

emissoras afiliadas

emissor-receptor

emoção (3)

ensino (3)

ensino de arte

ensino de Comunicação

ensino de jornalismo

ensino-aprendizagem

ensino-pesquisa

entretenimento

erotismo

escola (14)

Escola de Frankfurt

escola pública (2)

escolaridade

escolarização

espetáculo

Estado (2)

Estado-nação

Estados Unidos

estereótipo

estética da violência

estruturas cognitivas

estruturas opositivas

estudos de recepção

ética (4)

EUA

evasão escolar (2)

exclusão (2)

experiência lúdica

expressão 
fantasia (2)

ficção

ficção televisiva (2)

filme de ficção

filme

filmografia

formação de professores

formação humanística

formação

fotografia (2)

Frida Kahlo

funk

futuro

gênero

gerenciamento

gestão da comunicação

globalismo

globalização (3)

gramática textual

graphic novels

Grécia clássica

guerra

hemeroteca pedagógica

hipertexto

história (5)

história cultural

história da arte

história em quadrinhos (3)

história

humanismo

iconografias ameríndias

identidade

idosos

Igreja

ilustração

imagem e educação

imagem (2)

imaginário

imprensa

inclusão social

indivíduo

indústria cultural

infanto-juvenil

informação (3)

informática (5)

instituição escolar

intelectuais

intelectual

interação

interação cultural interatividade (2)

interdisciplinaridade

internacionalização midiática

Internet (5)

inter-relação

jogo da leitura

jogos teatrais

Jornal do Brasil

jornal eletrônico

jornal escolar

jornal impresso

Jornal Nacional

jornal (4)

jornalismo didático

jornalismo e ensino

jornalismo (4)

jovem

jovens

justiça cultural

justiça

LEC - Laboratório de Ensino de

Ciências

legislação

Lei de Diretrizes e Bases (4)

leitura (3)

leitura crítica (2)

Leonardo Pareja

linguagem teatral

linguagem

linguagem narrativa

linguagem-pensamento

linguagens documentárias

linguagens e códigos

linguagem e cognição

livro

lúdico

manipulação

marginalização

marketing católico

marketing político

marketing

marketing cultural

Marrocos

marxismo

matemática

Mato Grosso

mediação,

mediação tecnológica na educação

mediações (2)

mediador cultural, 
meio ambiente (2)

meios de comunicação (7)

memória

mercado

mercado fonográfico

método

mídia eletrônica

mídia (6)

mídias educativas

Ministério da Saúde

mito

mitologias

modernidade (3)

Monteiro Lobato

morfologia do conto

multiculturalismo (3)

multidisciplinar

multimídia (2)

mundo árabe

mundo do trabalho

museu

música

nação

nacionalismo

narrativa (2)

negro africano

neoliberalismo

Nordeste

norte-americanos

notícia

novas tecnologias (5)

O Dia

O Globo

O palácio da memória

obra de arte

oligopólios

operadores

organização popular

ouvinte

pacto social

pais

palavra-geradora

participação

partido

Paulo Freire

pedagogia da comunicação

Pedagogia da imagem (2)

pedagogia dialógica

pedagógica

pensamento narrativo pesquisa (2)

Pica-pau

Pierre Bourdieu

pintura

plano decenal

poder simbólico

política (2)

políticas de comunicação

política cultural (2)

política de educação

política social

pós-modernidade

prática docente

prazer

precatórios

preconceito

presentismo

produção de cultura

produção radiofônica educativa

produção teórica

professor (10)

programa educativo (2)

programa governamental

programação

programação de TV

programas de auditório

propaganda (3)

Proposta Triangular

provérbio

publicidade/propaganda

público-alvo

qualidade de ensino (2)

qualificação do jornalista

rádio comercial

rádio (2)

realidade

realidade virtual

recepção de telenovelas

recepção urbana e rural

recepção (4)

recursos didático-pedagógicos

Rede Globo (3)

redes mundiais

região do $\mathrm{ABC}$

relações interétnicas

renovação católico-carismática

repetência (2)

representação

Ribeirão Preto

Roquete Pinto 
saber

sala de aula

salários

saúde

Saúde no ar

saúde

SBT

sedução (2)

segurança

Semana de 22

sensibilidade

sentimento

serviço de alto-falante

sexualidade

sociabilidade

social-democracia

socialismo

sociedade civil

socioeconômica

sujeito

Teatro de Arena

teatro jesuítico

teatro-educação

tecnologia (3)

tecnologias (2)

tecnologia da informação

tecnologias digitais

telecomunicações (2)

teledramaturgia

\section{Artigos Internacionais}

Autores (e número de ocorrências)

AGUIRRE, Jesús Maria

APARICI, Roberto

BECHELLONI, Giovanni

BERGOMAS, Gabriela

BIERNATZKI, William E. (4)

CERVERA, Rafael Calduch

CORDELIAN, W.

CUNHA, Isabel Ferin

FREY-VOR, Gerlinde

GAGLIARDI, Mafra (2)

Gómez, Guillermo Orozco

KAPLÚN, Gabriel

KAPLÚN, Mário

Temáticas (e número de ocorrências)

agenda setting

aprendizado telejornais (3)

telejornalismo,

telenovela (4)

telenovela brasileira

televisão (11)

teoria

território digital

textos ficcionais

transdisciplinaridade

transmissão de informação

Triangular

TV a cabo (2)

TV comunitária

TV Escola

TV por assinatura

Um salto para o futuro

universidade

utopia

valores éticos

Vera Cruz

vídeo (2)

videogame

videogravação

Vila Sésamo

violência (5)

virtual

World Trade Center

Xochiquétzal

Yellow Kid
MAZZIOTTI, Nora

MARTÍN-BARBERO, Jesús (3)

MURCIANO, Marcial

Olivier, Bruno

OROZCO GÓMEZ, Guilhermo (3)

Pecora, Norma

REIS, Hiliana

SALVADORI, Chiara

THOMAS, Pradip (3)

TODA Y TERRERO, José Martínez de

(3)

VILCHES, Lorenzo

WHITE, Robert A. (7) aprendizagem

audiência (4) 
avaliação

\section{BBC}

cidadania (2)

cidade

ciências da comunicação

Colômbia

comunicação (2)

comunicação/educação

comunidade

conhecimento (2)

consenso cultural

consumo

criança

crianças (3)

cultura (2)

cultura popular

democracia (2)

destinatário

diversidade cultural

ecossistema comunicativo

educação

educação a distância (3)

educação não-formal

educação para os meios (3)

eixo comunicacional

eixo conceitual

eixo pedagógico

ensino

ensino presencial

entretenimento

entrevista

escola (4)

espaço público

espectador (2)

Estados Unidos

estudos culturais

estudos de audiência

estudo dos efeitos

exclusão

experiência estética

experiência teatral

fluxos de informação

formação de comunicadores

formação de professores

fruição teatral

globalização (5)

identidade cultural

identidade

Ideologia (2)

influência interacionismo simbólico

internet (3)

Itália (2)

material educativo

mediações

meios de comunicação (7)

melodrama

mensagem

mercado

mídia

mito (2)

multimídia

nova ordem mundial

novas tecnologias (3)

pedagogia (2)

pesquisa (2)

pluralismo

políticas de educação

política educacional

Portugal

programação infantil

professor

rádio (2)

rádio-escola

recepção (6)

recepção infantil

receptor/audiência

receptores (2)

Rede Globo

regulamentação (2)

rural

satélites na educação

serviço público

soap opera

socialidade

sociedade da informação

sociedade virtual

sujeito

teatro (2)

tecnologia (4)

tecnologia da informação

tecnologia digital

teleaudiência

telenovela

telespectadores

televisão (12)

teoria

teorias

terrorismo

transmissão educativa 
transnacionais (2)

UNESCO

União Europeia (2)

universidade virtual

\section{$\underline{\text { Entrevista }}$}

Participantes

Armand Mattelart

Beth Carmona

Carla Camurati

Dermeval Saviani

Duda Mendonça

Eva Wilma

Fernando Faro

Gabriel Priolli

Gianfrancesco Guarnieri

Guillermo Orozco Gómez

Heloísa Dupas Penteado

Isa Grinspun Ferraz

Jânio de Freitas

Jesús Martín-Barbero

Temáticas (e número de ocorrências)

agenda pública

América Latina

Armand Mattelart

ator (3)

atriz (2)

Beth Carmona

Brasil (2)

campanha política

canal universitário

Carla Camurati

Carta Capital

Castelo Rá-tim-bum

censura

cidadania (2)

cidade cenográfica

cinema (6)

Cinema Novo

comunicação (2)

conhecimento

consumo

controle social da mídia

crítica

cultura popular

cultura

democracia

Dermeval Saviani urbano

uso das tecnologias

violência (2)

violência na TV
José Wilker

Lauro César Muniz

Luís Gonzalez

Maria Thereza Fraga Rocco

Mário Fanucchi

Mário Lago

Mino Carta

Nílson José Machado

Nílton Travesso

Renato Ortiz

Roberto Muylaert

Ruth de Souza

Ruy Guerra didática

educação (4)

educação a distância (2)

emissora pública

ensaio

ensino básico

ensino fundamental

escola (2)

escritor

espaço público

estética

Eva Wilma

Fernando Faro

Folha de S. Paulo

formação de professores

Gabriel Priolli

Gianfrancesco Guarnieri

globalização (2)

Guillermo Orozco Gómez

Heloísa Dupas Penteado

história

identidade

imagem

informação

interprogramas

Jânio de Freitas 
Jesús Martín-Barbero

jornal

Jornal do Brasil

jornalista

jornalismo (3)

José Wilker

juventude

latino-americano

Lauro César Muniz

lead

leitura crítica dos meios

Maria Thereza Fraga Rocco

Mário Fanucchi

Mário Lago

marketing

marketing político

Mino Carta

música

negro

Nílton Travesso

novas sensibilidades

parâmetros curriculares

pedagogia

política

primeira página

professor

programação (2)

programas educativos

projeto

propaganda eleitoral

Rádio USP rádio (2)

Rede Globo

relação pedagógica

Renato Ortiz

revista

Roberto Muylaert

Ruth de Souza

Ruy Guerra

samba

São Paulo

SBT

sistema de avaliação

sociedade civil

sucesso

teatro de revista

teatro (6)

tecnologia

teledramaturgia

telenovela

teleteatro

televisão (8)

trabalho

TV Cultura (4)

TV educativa (2)

TV Escola (2)

TV pública

TV PUC

TV Record

TV Tupi

valores

Viagens de leitura

\section{Crítica}

Autores (e número de ocorrências)

ALMADA, Izaías (2)

BARCA, Lacy

BARBOSA, Ana Mae

BUCCI, Eugênio

CITELLI, Adílson Odair (3)

COELHO, Marcelo

COSTA, Maria Cristina Castilho (2)

D. ELBOUX, José R

FADUL, Anamaria

FRANCO, Marília

GUERRA, Gutemberg (2)

Hamburger, Esther

LEAL FILHO, Laurindo Lalo

LIMA, Solange M. Couceiro de

Machado, Arthur Versiani

MIRABAL, Julia

MENDONÇA, Mary Enice Ramalho de

(2)

MOTTER, Maria Lourdes (6)

NOVELINO, Elias

PAES, José Paulo

PALLOTTINI, Renata (2)

PELLEGRINI, Tânia

Prieto, Benita

SALES FILHO, Valter Vicente

SALIBA, Elias Thomé

SANT'ANNA, Catarina

TOMÁS, Lia

XAVIER, Ismail 
Temática (e número de ocorrências)

A Voz do Brasil

Amazônia

Amigos da escola

análise qualitativa

Andy Warhol

anos 60 (2)

Antônio Conselheiro

arte

audiência

audiovisual

autoritarismo

banalização

Benetton (2)

biblioteca

Bicho de sete cabeças

Big Brother Brasil

Brasil

Bruno Barreto

Cabrião

Canudos

Carlos Lamarca (2)

Casa dos Artistas

censura

Central do Brasil

Cidade de Deus

cinema brasileiro

cinema latino

cinema nacional (5)

cinema novo

computador

comunicação e educação

comunicação

controle social

cotidiano

cultura de massa

cultura

curta-metragem

delação

democracia

democratização do rádio

depoimento

dialogismo

discurso autoritário

ditadura militar

ditadura

diversidade (2)

divulgação científica

dramaturgia educação a distância

educação artístico-musical

ensino da arte

escola (2)

Estado autoritário

Estado de Israel

estética

estética da fome

Euclides da Cunha

Exodus

família

Festival de Cannes

Festival de Gramado

Festival

ficção-realidade

filme publicitário

filme (2)

filmes históricos

fotografia

gêneros

Globo Ciência

Globo Repórter

guerra de audiência

Guerra de Canudos

Havana

história (2)

humor

identidade

imaginário

interação verbal

Istó É

Ivani Ribeiro

Jorge Andrade

jornal

jornalismo (2)

Questão Palestina

Lais Bodanzky

Lei do Audiovisual

lendas

língua portuguesa

Linha Direta

livro (3)

longa-metragem

Luana

manipulação da informação

maniqueísmo

meios de comunicação

memória 
metalinguagem

minissérie

mitos

mulher

música popular

negro (2)

neo-realismo

novas tecnologias (2)

$O$ carteiro e o poeta

$O$ fim do mundo

O que é isso, companheiro? (2)

O Rei do Gado

oligopólio

Os ossos do Barão

Oscar

outdoor (2)

Pablo Neruda

palavra escrita

palavrão

paródia

pensamento verbal

pensamento visual

poesia

pornochanchada

preconceito (2)

Presídio Tiradentes

presos políticos

professor

programa policial

\section{Depoimento}

\section{Participantes}

ABREU, Luís Alberto de

ALMADA, Izaías

AMORIM, Rita

BASTOS, Heliodoro

BATISTA, João Antônio

BRAGA, Cristina

CAMPOS, Rosi

CARUSO, Paulo

CORREIA, Eduardo Luís

D. ELBOUX, José R.

DUARTE, Neide

FERREIRA, Ricardo Alexandrino

GOMES, Ana Luisa Zaniboni

KOTSCHO, Ricardo

LEONE, Eduardo publicidade (3)

publicidade enganosa

público

qualidade de programação

Radiobrás

realidade

realidade brasileira

reality show

Rede Globo (5)

remake

reportagem

semanário humorístico

Sérgio Rezende

sertanejo

sexo

short-list

Sistema manicomial

sistema público

teatro brasileiro

teleconferência

teledramaturgia

telejornal

telenovela (5)

televisão (5)

teorias da comunicação

Trilogia suja de Havana

videoconferência

violência

LOVETRO, José Alberto

MORAES, A. P.

MUNIZ, Lauro César

OLIVEIRA, Cláudia Barcellos de

OLIVEIRA, Dênnis

PALLOTTINI, Renata

PINHEIRO, Chico

RUY, José Carlos

SANCHEZ, Inaiê

SANTOS, Moisés

SILVA, Paulo Augusto

SOUZA, Sérgio

TAPAJÓS, Renato

VAZ FILHO, Pedro Serico

ZAKZUK, Maísa 
Temática (e número de ocorrências)

Abril

administração pública

arquétipo

arquivo jornalístico

assessoria de imprensa (2)

Avenida Brasil

Bar Brasil

Brasília

briefing

Caderno de Encartes

campanha publicitária

Caros Amigos

cartun

cartunista

charge (2)

censura

Chico Pinheiro

cidadania (3)

cidade

Ciência em Debate

cinema

cinema documental

cliente

comunidade

conterrâneos velhos de guerra

corrupção

crônica de viagem

Cuba

ditadura militar (2)

divulgação

documentação

documentário

dramaturgia

editor

Editora Senac

ensino

erudito

ética

ética profissional

Federação dos Químicos

Florão da América

função social

gestão da comunicação (3)

história em quadrinhos

humor (2)

Ilha Rá-tim-bum

imagem

imprensa sindical

Incor
Izaías Almada

Jornal de Natal

jornalismo científico

jornalismo cultural

jornalismo especializado

jornalismo (5)

Lauro César Muniz

leitor

linguagem radiofônica

livro

mambembe

Mário Covas

memória

mercado editorial

mercado livreiro

minissérie

mitos

movimento popular

município

música brasileira

noticiário

Oboré

O Pasquim

oligarquia

operários

ouvintes

palavra

pauta

perfil profissional

poder político

política

prática jornalística

processo criativo

produção da informação

produção

produção em rádio

propaganda

profissão

profissional da imprensa

publicidade

público infantil

quadrinho de autor

radialista (2)

rádio (3)

Rádio Cultura

Rádio Gazeta

rádio

rádio-jornalismo

rádios comunitárias 
Realidade

Rede Globo (2)

redes temáticas

release

Renata Pallottini

Renato Tapajós

Reportagem (2)

repórter

Ricardo Kotscho

romance

Rosi Campos

roteiro

\section{$\underline{\text { Experiência }}$}

Autores

ALMEIDA, Theodora M. Mendes de

ALVES, Januária Cristina

ANDRADE, Sílvia Letícia de

BARROS, Miriam da Rocha

BERTINI, Sumaia Barizon

BONATELLI, Ivanhoé Robson

Marques

CAMPANHÃO, Izilda Bueno Barrios

CARVALHO, Sibéria Regina de

CAVALCANTE, Cláudia

COSTA, Clara Rosa da

DE BONIS, Maria Júlia Rangel

DEL VECCHIO, Rosângela

DUTRA, Susi Maria de Oliveira

FIGUEIREDO, Tânia Regina

Gonçalves

GRIGOLETTO, Rosângela A. da Silva

INÁCIO, Cleoni Fanelli

ITACARAMBI, Ruth Ribas

JUSTTI, Antônia Aparecida

LEITE, Marli Siqueira

LIMA, Sílvia Ferreira

LINO, Jaine Rita Celentano

LUKIANCHUKI, Cláudia

\section{Temática (e número de ocorrências)}

aborto

ação cultural

adolescente

Alexandre e outros heróis

aluno (2)

alunos

alunos de terceira série

ambiente
Santo André

Sérgio de Souza

sonoplastia

teatro (3)

telejornalismo

telenovela

televisão

televisão educativa

TV Cultura

Unesp

voz (2)

$X$-Tudo
MAGNO, Maria Ignês Carlos

MARTINS, Jussara de Lara Sanches

MATTE, Ana Cristina Fricke

MEDINA, Cremilda

MERONI, Adriana Ignácio de Campos

OLIVEIRA, Regina Aparecida de

PENHALBER, Marisa de Jesus

PEREIRA, Cláudia Maria

PEREIRA, Marcos Aurélio

PINTO, Sílvia Lúcia Silva

RAMO, Regina Mara

RODRIGUES, Lúcia de Fátima Pereira

Santos

RODRIGUES, Maristela Ortolan

ROSA, Sandra Martins da

ROVAI, Marta Gouveia de Oliveira

SANTA LÚCIA, Maria Fernanda

Venturini

TAVARES, Cristiane Fernandes

TUZZO, Simone Antoniacci

VIDAL, Marly Camargo de Barros (2)

VIEIRA, Alice

VIOTTO, Márcia Regina

aprendizagem

Aqui Agora

artes

auto-aprendizagem

auto-estima (2)

boneco fantoches

bula de remédios

Cabri-Géomètre 
candidatos

\section{Ciência}

composição artística

comunicação e expressão

conhecimento

conto

cotidiano (3)

criança

criatividade (2)

culinária

cultura popular

curiosidade infantil

defasagem

diagramação

dicionário

direito da mulher

discurso

elaboração de textos

ensino (2)

ensino de Ciências

ensino de Português (3)

ensino de Sociologia

ensino fundamental (8)

ensino médio

ensino

ensino-aprendizagem

ensino-pesquisa

erro

escola (4)

escola pública

escrita

Estadinho

ética

experiência

experiência pedagógica

família

ferramenta pedagógica

ferramenta

ficção

Folhinha

fundamental

geometria

Graciliano Ramos

habilidades comunicativas

história (2)

histórias em quadrinhos

imaginário

informática educacional

informática interdisciplinar (2)

interdisciplinaridade

interpretação de textos

jornal escolar

jornal infantil

jornal na escola

jornal (8)

jornalismo (2)

leitura crítica

leitura (7)

língua portuguesa

linguagem dialógica

literatura

livro de receitas

$\log 0$

manchetes

matemática (2)

meio ambiente

meios de comunicação (3)

metodologia

multidisciplinaridade

música

música popular

notícia

oficina de contos clássicos

poesia (2)

português (5)

preservação ambiental

Presidente da República

Primeira Guerra

produção de textos (4)

produção textual

professor (5)

projeto informática educativa

projeto pedagógico (4)

projeto

prova

psicolingüística

racismo

reciclagem

reportagem

revista

sala de aula (5)

tema transversal

temas transversais

Turma da Mônica

vídeo-histórico

Vivência Pedagógica 


\section{$\underline{\text { Poesia }}$}

\section{Autores abordados}

Bertold Brecht

Caetano Veloso

Carlos Drummond de Andrade (3)

Cecília Meireles

Cora Coralina

Federico García Lorca

Fernando Pessoa

João Cabral de Melo Neto (2)

Jorge Andrade

\section{$\underline{\text { Servicos }}$}

\section{Autores}

AIDAR, Flávia

AJZENBERG, Elza

ALBUQUERQUE, Maria Elisa Vercesi de

ALVES, Tarcísio Luís D'Almeida

BARROS FILHO, Clóvis

BATISTA, Marta Rossette

BELLESA, Mauro

BENTO, Maria Aparecida Silva

CAMPOS, Maria Lúcia Rocha

CARMONA, Beth

CONTI, Vivaldo Luiz

COSTA, Maria Cristina Castilho

CERAVOLO, Suely Moraes

FRANCO, Marília

GONÇALVES, Lisbeth Rebollo (2)

GUERRA, Marco Antônio

HADDAD, Sérgio

MAKINO, Mioko

Temática (e número de ocorrências)

ação educativa

acervo (3)

anatomia

animais

antropologia

arquivo

arte brasileira

arte contemporânea

arte contemporânea brasileira

arte e ciência

arte-educação

artes plásticas

artes visuais
Manuel Bandeira

Oswald de Andrade

Pablo Neruda

Patativa do Assaré

Raquel Naveira

Renata Pallottini (2)

Sérgio Caparelli

Thiago de Mello

Vinicius de Moraes

MARIANA, Arani Nanci Bomfim (2)

MEDINA, Sandra

MESQUITA Neto, Paulo

MUNIZ, Sérgio

PACHECO, Elza Dias

PERALES, Sérgio

PERROTI, Edmir

PIOVESAN, Ângelo

QUEIROZ, Jandira

ROSSINI, Rosa Ester

SANGIORGI, Oswaldo

SILVA, André Chaves de Melo

SILVA, Dilma Melo

SOARES, Ismar de Oliveira (3)

SOARES, Vera

SOUZA, Márcia Furtado Ribeiro de

TRIGO, Lígia

VILLELA, Milú

XAVIER, Marco Antônio

astronomia

atendimento

bibliotecas (2)

Bienal

canal universitário

capacitadores

catálogo

CECAE

CEDI

CEERT

Centro Mário Schenberg

Cibernética Pedagógica

cidadania 


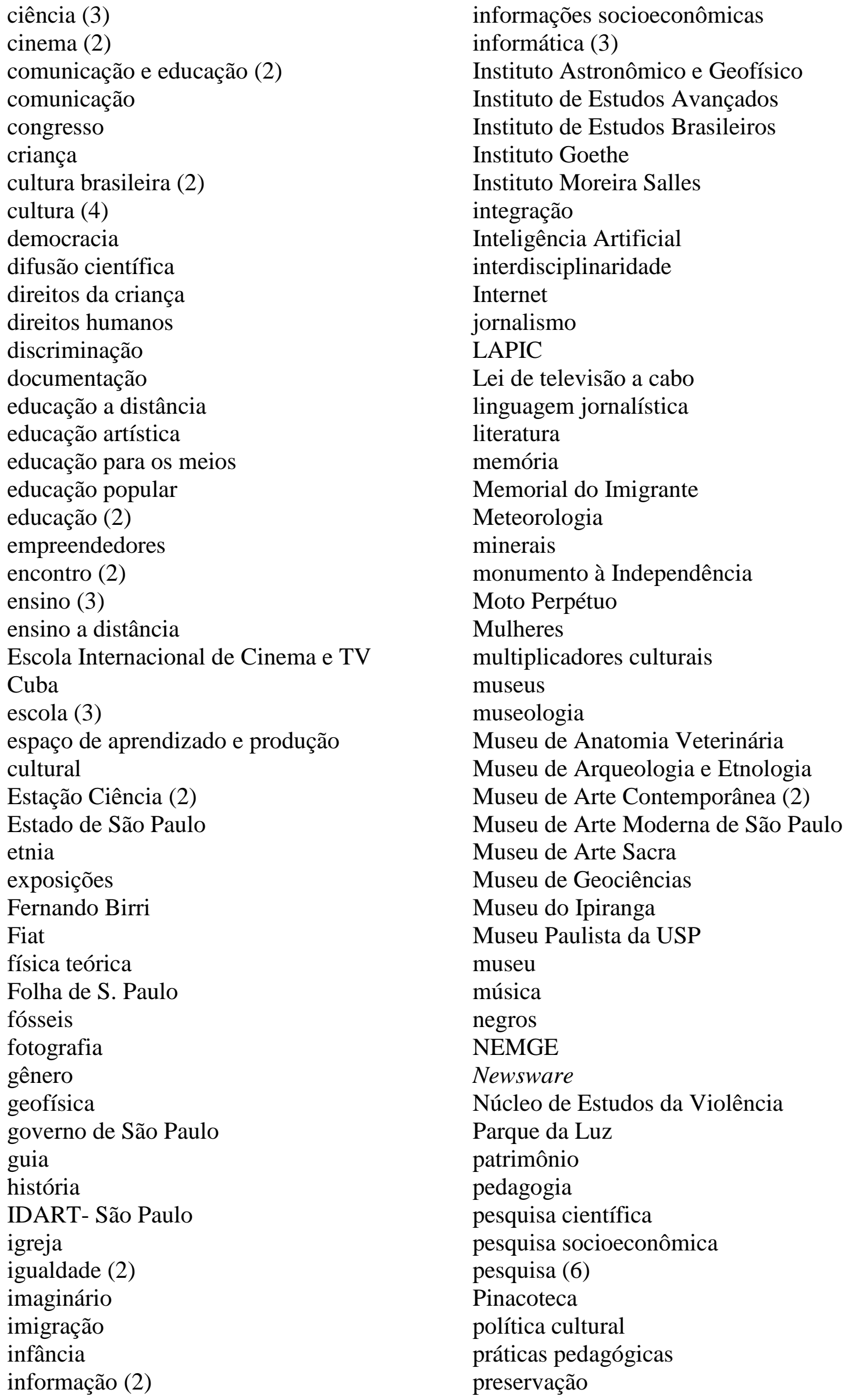

informações socioeconômicas

informática (3)

Instituto Astronômico e Geofísico

Instituto de Estudos Avançados

Instituto de Estudos Brasileiros

Instituto Goethe

Instituto Moreira Salles

integração

Inteligência Artificial

interdisciplinaridade

Internet

jornalismo

LAPIC

Lei de televisão a cabo

linguagem jornalística

literatura

memória

Memorial do Imigrante

Meteorologia

minerais

monumento à Independência

Moto Perpétuo

Mulheres

multiplicadores culturais

museus

museologia

Museu de Anatomia Veterinária

Museu de Arqueologia e Etnologia

Museu de Arte Contemporânea (2)

Museu de Arte Moderna de São Paulo

Museu de Arte Sacra

Museu de Geociências

Museu do Ipiranga

Museu Paulista da USP

museu

música

negros

NEMGE

Newsware

Núcleo de Estudos da Violência

Parque da Luz

patrimônio

pedagogia

pesquisa científica

pesquisa socioeconômica

pesquisa (6)

Pinacoteca

política cultural

práticas pedagógicas

preservação 
professor

projetos educativos

protagonistas juvenis

racismo

rádio educativa

Rádio USP

Rede Vida

redes neurais

roteiro artístico

Seade

seminário

serviço (2)

serviços comunitários site educativo

sociedade civil

tecnologia

televisão (3)

TV Cultura

TV USP

universidade

USP

veterinária

vídeo

vídeo-educação

violência

visitas

2004 - 2011

\section{$\underline{\text { Artigos Nacionais }}$}

Autores (e número de ocorrências)

ABRÃO, Maria Amélia Paiva

ALMEIDA, Maria José P. M. De

Almeida

ANDRELO, Roseane

BACCEGA, Maria Aparecida (2)

BALOGH, Anna Maria

BARBALHO, Alexandre Almeida

BARCA, Lacy

BARI, Valéria Aparecida

BARRETO NETO, Ranylson Sá

BARRETO, Angela Maria

BATISTA, Aline Maria de Melo

BATISTA, Sueli Soares dos Santos

BERGER, Christa

BRAGA, José Luiz (2)

BRAGA, Júlio O.

CALLEGARO, Tania

CANELAS, Antonio Albino Rubim

CASTRO, Maria Helena Steffens de

CHAVES, Juliana Campos

CITELLI, Adilson (2)

COELHO, Marcos A.,

COSTA, Maria Cristina Castilho (4)

CURI, Fabiano Andrade

DALPIAZ, Jamile

DELIBERADOR, Luzia M. Yamashita

DIAS, Ângela Álvares Correia

DIAS, Ricardo Henrique Almeida

DITTRICH, Ivo José

DRIGO, Maria Ogécia

FANINI, Ângela Maria Rubel

FIGARO, Roseli

FIGUEIREDO, Ana Maria C.

FILHO, André B.

FILHO, Genésio Zeferino da Silva

FONTANARI, Rodrigo

FONTINELES, Flávia de Souza

FREDERICO, Celso (3)

GARCIA, Wilton

GOMES, Adriano Lopes

GOMES, Mayra Rodrigues

GRUZMAN, Eduardo,

HOFF, Tânia Márcia Cezar

JACKS , Nilda

JESUS, Paulo de;

JOSGRILBERG B., Fabio

JUNIOR, Walter de Souza

LEANDRO, Anita

LEÃO, Andréa Borges

MARCELOS, Maria de F.

MARQUES, Jane A.

MARTINS, Marina Rodrigues

MELO, José Marques de (3)

MENEZES, Daiane Boelhouwer

MORAES, Carlos Vinicius Oliveira de

MOTTER, Maria Lourdes

JAKUBASZKO, Daniela

MOURA, Karina da Silva

MUNGIOLI, Maria Cristina Palma

OLIVEIRA, Cristiane M.

PALLOTTINI, Renata

PATRIOTA Nara Silvana Albuquerque 
PAULA, Luiz Antonio de PENTEADO, Heloísa Dupas PEREIRA FILHO, Edson Pereira da Silva

PIATTI, Deise Ellen (2)

PIRES, Eloiza Gurgel

RODELLA, Cibele A

RODRIGUES, Edivânia Duarte

ROMANCINI, Richard

ROZENDO, Adriano da Silva

ROZENDO, Suzana da Silva

RUBIM, Antônio Albino Canelas

RUBIM, Lindinalva

SACRINI, Marcelo

SANTOS, Roberto Elísio dos

SCHMIDT, Beatriz

SCHNEIDER, Marco

SENA, Ercio

SETTON, Maria da Graça Jacintho

SILVA, Acir Dias da (2)

\section{Temáticas (e número de ocorrências)}

\section{A bela Junie}

A princesa Raga-Si

alfabetização

Alfredo de Carvalho

alteridade

ambientes mediáticos

análise de discurso

aprendizagem significativa

apropriação

apropriações e representações

midiáticas

argumentação

arquitextualidade

arquivos

Arrelia

Arte contemporânea

As Meninas Superpoderosas

audiência

áudio

aulas radiofônicas

Bakhtin

best-seller

biblioteca

Brasil (2)

brinquedos

categorias de análise

censura (2)

chat,
SILVA, Rosane

SIQUEIRA, Vera H. F.,

SOARES, Ismar de Oliveira (3)

SOBREIRA, Roberto

SOUSA JUNIOR, Walter

SOUSA, Juliana Pereira de

SOUSA, Walter de

SPONHOLZ, Liriam

TARGINO, Maria das Graças

TAVARES, Marcus

TRINDADE, Eneus

VERGUEIRO, Waldomiro (2)

VERONESE, Marília Veríssimo

VICENTE, Eduardo

VICINI, Magda Salete

VIDAL, Marly C. B.

Vieira, Ana Carolina Rampazzo

VITORIO, Benalva da Silva

WENZEL, Maria Cristina Rosa

ZANI, Ricardo

cidadania (4)

ciências contábeis

cientistas

cinema de poesia

cinema e educação

cinema educativo

cinema (5)

$\operatorname{circo}(2)$

circo-teatro (2)

colaboração,

comunicação e autosugestão

comunicação e educação (3)

comunicação (21)

comunicador educacional

consumo (2)

controle remoto

co-produção

corpo

cotidiano

critérios de noticiabilidade

criticidade

cultura

cultura digital

cultura global

cultura jovem

cultura midiática

cultura popular

currículo de graduação (Comunicação) 


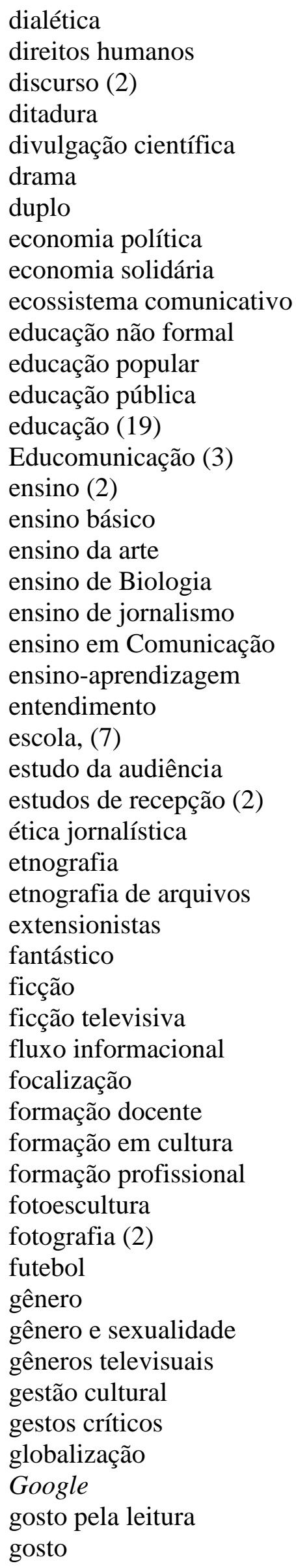

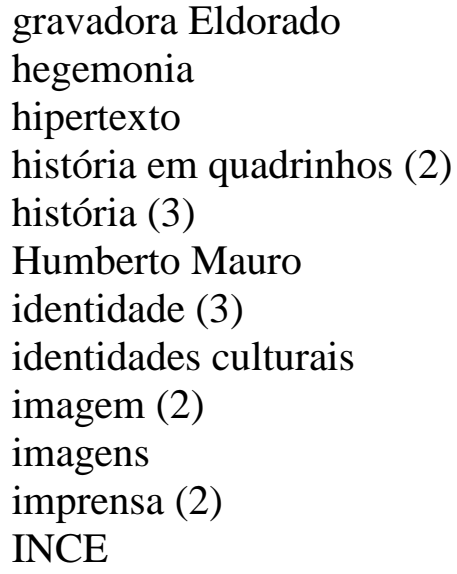


meios de comunicação de massa

memória (2)

memória estética (2)

memória midiática

memória subterrânea

mercado editorial

mercadoria (2)

messenger

metáforas

método

Michel de Certeau

microssérie

mídia

mídia de massas

midiologia (2)

minissérie Grande Sertão: Veredas

minissérie

modernidade (2)

movimento anarquista

movimento social

música (2)

música independente

música popular brasileira

nação e televisão

nacionalismo

new technologies

notícias

oralidade

organização da cultura

Orkut

palavra

paradigma educacional emergente

paradigmas da imagem

paratextualidade

pedagogia

pedagogia da imagem

Peirce

percepção

perfil

persuasão

pesquisa (2)

Piolin

Piscator

poder

poesia

poética da experimentação

políticas culturais

pós-modernidade (2)

práticas escolares

problema de pesquisa produção cultural

produção de sentido da comunicação

produção (2)

projeto de pesquisa

propriedade intelectual (2)

publicações brasileiras

racionalidade

Rádio Rural de Natal

rádio

recepção (5)

relações públicas

reportagem (2)

representação

representação da natureza

República de Weimar

retórica

retrato fotográfico

revistas educativas

rituais

Romance d'A Pedra do Reino e o

Príncipe do Sangue do Vai-e-Volta

São Paulo

semiótica (2)

sentido identitário

sexo

significação

silenciamento

sites de relacionamento

social

sociedade

street paper

subjetividade

sujeito crítico

suporte pedagógico

teatro político

teatro (5)

tecnologia da informação

tecnologia de informação e

comunicação

tecnologia (3)

tecnologias

teledramaturgia (2)

tele-ficção

telejornal

telenovela brasileira

telenovela Malhação

telenovela (4)

televisão (3)

temas sociais

tematização 
teoria crítica

teoria da ação

teoria da comunicação

teoria evolutiva

teorias da comunicação

terceiro entorno

texto publicitário

tópicos

\section{$\underline{\text { Artigos Internacionais }}$}

Autores

ALVARADO, María del Mar Ramírez

ÁLVAREZ, Inmaculada Gordillo

BACCIN, Cristina

BORDENAVE, Juan Díaz

BARONE, Antonio Fernando Corrêa

BARONE, Fernando

BERKIN, Sarah Corona

CABANNE, Josseline I.

CARRERO, Jacqueline Sánchez

CUNHA, Isabel Maria Ribeiro Ferin da

DALPIAZ, Jamile

DRUETTA, Delia Crovi

GALÁN, Virginia Guarinos

Temáticas (e número de ocorrências)

alfabetização audiovisual

América Latina

análise literária

análise

aprendizagem

britânica

canto popular

carência

censura

Ciespal

cinema

cobertura de conflitos

comunicação comercial

comunicação ecológica

comunicação política

comunicação pública

comunicação (4)

conhecimento

contador de histórias

contos orais

cotidiano

crises

cultura (2) tradução poética, literatura

TV a cabo

utopia

vídeo educativo

videogame

Walter George Durst

zapping

Zélia Gattai

GARCÍA, José Sixto

Gómez, Guillermo Orozco

GÓMEZ, J. Ignacio Aguaded

KRACKE, Lúcia Villela

KRACKE, Waud H.

MORIZOT, Dominique

JAKUBASZKO, Daniela

SAMPIO, Dolors Palau

SANTISO, María Salgueiro

SANTOS, Graça dos

SUNWOLF, J. D.

VELASCO, María Teresa Quiroz

cultura nacional

democracia participativa

educação infantil

educação (5)

escola (2)

escrita

estética

estudos quantitativos

fala

ficção

folclore

formação profissional

fotografia (2)

Françoise Sironi

funções estatais da sociedade civil

Georges-Devéreux

gestão

história

imagem e comunicação

imprensa (2)

indústria cultural

infância

informação 
Internet

jogo

jornalismo (2)

linguagem audiovisual

linguagem escrita

literatura

media

meio ambiente

meios de comunicação

memória (2)

mídia

migrações

minorias

mito

música

narrativa

narrativas

neoliberalismo

novas tecnologias

oralidade

organização

Parintintim

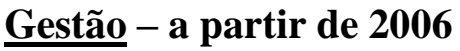

\section{Autores}

ALVES, Juliana Tourrucôo

ANDRADE, Katherine Realle Nóbrega

de

ANDRADE, Rogério Pelizzari de

ARASHIRO, Leda Márcia

BLUM, Andréa

COSTA, Maria Cristina Castilho

HYPPOLITO, Cristiane

IVO, Consuelo

JACOB, Eduardo Louis

Temáticas (e número de ocorrências)

abastecimento

alunos

arte (2)

artes

biblioteca

cartas de reclamação

Central de Trabalho e Renda

centro de São Paulo

CETVN

cidades

Ciências da Comunicação

comércio política

Portugal

povos indígenas

práticas educativas

Radiobrás

radiodifusão (2)

religião

repressão

responsabilidade social

salazarismo

SIC

sujeito

tecnologia

Tecnologias de Informação e

Comunicação (TICs)

televisão

tempo social

terceiro mundo

TIC

tradições espirituais

videocultura
KONDZIOLKOVÁ, Monica

LEMOS, Ligia Maria Prezia

MAMAN, Armando Levy

MOURA e SOUZA, Ana Paula Aleixo

de

PICCIARELLI JÚNIOR, Sergio

RIBEIRO, Ademir

SANTANA, Cristiane Batista

SOMENZARI, Luciano

VANTINE, Vanessa

comunicação gráfico-ambiental

comunicação não verbal

comunicação on-line

comunicação pública

comunicação (6)

cotidiano

crítica

cultura (2)

cultura de resistência

desemprego

Editora Abril

educação (2) 
Educomunicação

emprego

encartes especiais

escola

espaço público

especialização lato sensu

feira livre

formação profissional

gestão da comunicação (4)

Guarulhos

identidade (2)

imagem corporativa

imaginário

imprensa

Intercom 2006

internet (3)

jornalismo

Masp

\section{Entrevista}

\section{Participantes}

Ana Cabrera

André Barbosa Filho

Antonio Nóbrega

Cao Hamburguer

Danilo Santos de Miranda

Elifas Andreato

Fernando Rossetti

Francisco Whitaker

Geneviève Jacquinot-Delaunay

\section{Temáticas (e número de ocorrências)}

arte

artes gráficas

atividade

banda larga

biblioteca virtual

Cao Hamburger

capitalismo

cineasta

colaboradores

comércio

comunicação (4)

comunicação-educação

comunidade

cultura (3)

dança

Desenvolvimento social

desigualdade social mediação (2)

memória (3)

metrô

mídia impressa

mídias

movimento operário

museus

paisagem urbana

pertencimento

poesia

Porto

professor

propaganda de massa

renda

revistas

Santos

sindicato

telenovela

Heródoto Barbeiro

Isabella Bruni

João Antonio Zuffo

Jorge Huergo

Lúcia Araújo

Maria Luiza Marcílio

Paulo Tatit e Sandra Peres

Pedro Primo Bombonato

Yves Schwartz

direitos humanos

educação (9)

educação a distância

educação continuada

Educomunicação

Elifas Andreato

ergologia

escola (2)

Escola de Comunicações e Artes

escola e mídia

Fórum Social Mundial

governo

história,

imprensa alternativa

inclusão social

indústria

infoera 
Interatividade

investimento social privado

Itália

jornalismo

mídia

mídias

movimentos sociais

multidisciplinaridade

música infantil

música

negra

movas mídias

novas tecnologias

parceria editorial

perfil

pesquisa demográfica histórica

política

políticas públicas

\section{Crítica}

Autores (e número de ocorrências)

AZEVEDO, Aline Fernandes de

BACCEGA, Maria Aparecida (4)

BUDAG, Fernanda Elouise

CARRASCOZA, João Anzanello (3)

CASAQUI, Vander (3)

CASTRO Gisela G. S (2)

CITELLI, Adílson

FILHO Clóvis B.

FREIRE, Denise de Oliveira

FURTADO, Juliana de Assis

Temáticas (e número de ocorrências)

A Lei e o Crime, aculturação

análise do discurso

audiência

automóvel

capitalismo pós-industrial

cinema (5)

comunicação de massa

comunicação e consumo (3)

comunicação e práticas de consumo

comunicação

consumo (2)

contra-hegemonia

crítica (2)

diálogo social

discurso jornalístico produção artística

projeto editorial

qualidade

rádio

recepção

rede mundial

revista Comunicação \& Educação

Sesc

teatro

telecomunicações

televisão digital

televisão educativa

televisão (3)

terceiro setor

trabalho,

TV Digital
GODOY, Amilton

GUIMARÃES, Margaret de Oliveira

MACEDO, Diana Gualberto de

MARCELINO, Rosilene Moraes Alves

MEUCCI, Arthur

OROFINO, Maria Isabel (2)

PALLOTINI, Renata (2)

ROCHA, Rosamaria Luiza (Rose) de

Melo

TONDATO, Márcia Perencin

educação (3)

egoísmo

espacialidade (2)

estratégia de resistência

estratégia

estudos de recepção

ética

governo Lula

grotesco

habitus

hegemonia (2)

história

identidade (2)

identidade nacional

ideologia

intertextualidade 
ironia

jornalismo

jovens

livro didático

marketing

mediação

mediações (3)

melodrama

mídia

mídias

modernidade

obra em aberto

Os Sertões

princípio

propaganda estatal

\section{$\underline{\text { Depoimento }}$}

\section{Participantes}

ABRAMOVICH, Fanny

BANDEIRA, Pedro

BELINKY, Tatiana

BERTAZZO, Ivaldo

BRENNAND, Francisco

COGHI, Cristina

COUTINHO, Eduardo

DEL NERO, Cyro

FRANCO, Marília

GODOY, Amilton

MARTINELLI, Mirella

Temáticas (e número de ocorrências)

adolescência

aprendizado

arte (2)

arte-educação (3)

autodidatismo

bossa nova

casa de detenção

censura

cerâmica

cibernética

cidadão

cinema

comunicação (2)

comunidade

cotidiano

criação literária

criação teatral

cultura negra
ProUni

publicidade (4)

Rebelde

recepção (6)

retórica

revista Veja

rizoma

seriado

teleficção

telenovela (3)

televisão (2)

trabalho (3)

utilitarismo

violência

NEVES, Déborah Pádua Mello

NOWILL, Dorina

PADIAL, Robinson

PALLOTTINI, Renata

PIMENTA, Flávio

SALDANHA, Paula

SANGIORGI, Osvaldo

SCAVONE, Fernando

TRINDADE, Raquel

cultura popular

dança (2)

dançante

desenvolvimento corporal

direção

ditadura militar

educação, (5)

Escola de Arte Dramática - EAD

escultura

expressão corporal

formação humanística

fotografia

gestão

Globinho

imagens

Infância

jornalismo (2)

literatura (2) 
literatura infantojuvenil (2)

matemática

Meninos do Morumbi

mímica

minissérie

mito

montagem

música (2)

música instrumental

narrativa

novas tecnologias

Oficina Brennand

poesia

presos

\section{$\underline{\text { Experiência }}$}

\section{Autores}

ALMEIDA, Lígia Beatriz Carvalho de BEJARANO Nelson Rui Ribas

BORTOLIERO Simone,

COELHO, Fernanda

COSTA, Maria Cristina Castilho

COUTO, Maria Elizabete Souza

CRUZ, Dulce Márcia;

DAMASCENO, Carolina Duarte

FREITAG, Vanessa

GOMES, Mayra Rodrigues (2)

GOUVÊA, Ana Regina

GUEDES, Caroline Lengert

ROSENTHAL, Hugo

\section{Temáticas (e número de ocorrências)}

agências experimentais

alfabetização

alfabetização audiovisual

ambiente virtual de aprendizagem

análise crítica

atividades on-line

brincadeiras infantis

chat

cibercultura

cidadania (3)

cinema

colaboração

comunicação comunitária (2)

concepções espontâneas

cultura midiática

divulgação científica produção (2)

professor

qualidade

Raquel Trindade

samba-jazz

São Paulo

sarau

teatro (6)

televisão, (4)

TV universitária

TV USP

virtual

Zimbo Trio
HINKLE, Érika

ILHA Paulo César Abdalla

LAGO, Cláudia

LAHNI, Cláudia Regina

LEÃO, Izabel

MALDONADO, Alberto Efendy

MARTINS, Luzenice M.

PEREIRA, Ana Catarina

PEREIRA, Antonia Alves

REICHERT, Julie

SOUZA, Adriana M.

TAVARES, Cristiane Fernandes

TONDATO, Márcia Perencin educação a distância (2)

educação ambiental

educação para as Ciências/ensino de

Ciências

educação (2)

Educomunicação (2)

ensino a distância

ensino de História

ensino de literatura

ensino em comunicação

ensino fundamental

espectador

ferramenta wiki (2)

formação de professores (2)

formalismo russo

games de simulação 
gestão da comunicação (2)

hipertexto (2)

informática

interatividade (3)

internet na educação

internet

jogos (2)

juventude (2)

leitor

leitura (2)

leitura e criação

linguagem

literatura

Mediação pedagógica

meios de comunicação

metodologia do ensino

mídia-educação

mídias digitais

Moodle

\section{Poesia}

Autores citados (e número de ocorrências)

Adélia Prado

Berthold Brecht

Cacaso

Caetano Veloso

Carlos Drummond de Andrade (2)

Cecília Meireles

Chico Buarque

Eduardo Alves da Costa

João Cabral de Melo Neto (2)

Machado de Assis

Mário de Andrade

Manuel Bandeira (3)

Manuel Carneiro de Souza Bandeira

Filho

Manuel de Barros

\section{$\underline{\text { Servicos }}$}

\section{Autores}

narrativas audiovisuais na escola

pública

participação e rádio (2)

poesia

polifonia

prática educativa

produção de vídeo

produção midiática

programa JCE

projeto social impresso

projetos experimentais

projetos integrados

protagonismo

revista Viração

SimCity4

televisão

tema transversal

Twitter

vídeo
Mário Faustino

Mário de Andrade

Mario Quintana

Martin Niemöller

Murilo Mendes

Orides Fontella

Paulo Leminski

Paulo Vanzolini

Solano Trindade

Tom Zé

Vinicius de Moraes

Vladmir Maiakovski 
ALMEIDA, Maria Christina Barbosa de ARAUJO, Emanoel

AVANCINE, Laura

BARBOSA, Frederico

BRAYNER, Vânia

BUCCI, Eugênio

CORREIA, Donny

FILHO, Deusdédit Carneiro Leite

GUEDES, Angela Cardoso

IVO, Consuelo (4)

\section{Temáticas (e número de ocorrências)}

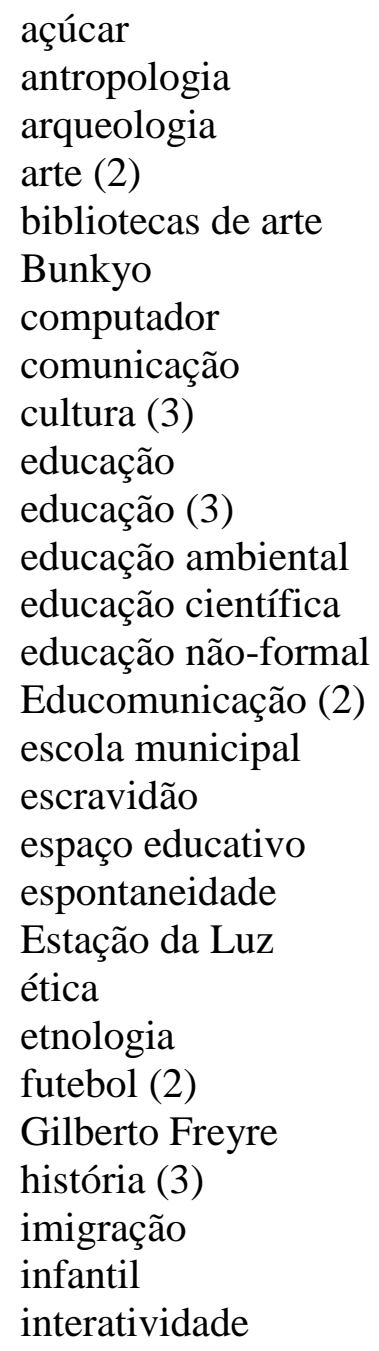

KONDZIOLKOVÁ, Monica LEÃO, Maria Izabel de Araújo LEÇA, Fernando MOTOYAMA, Shozo

PINA, Paulo Simões de Almeida PRANZETTI, Dirce Maria;

SANJAD, Nelson

SOARES, Ismar de Oliveira

TOLOZA, Maria Cecília

\author{
jornalismo \\ Kasato Maru \\ língua portuguesa \\ literatura \\ livros infantis \\ Maranhão \\ meios de comunicação \\ memória \\ memória (2) \\ mercado editorial \\ metodologia triangular \\ museologia \\ Museu do Homem do Nordeste \\ Museu Histórico Nacional \\ Museu Paraense Emílio Goeldi \\ museu (7) \\ nacionalismo \\ negro \\ Nordeste \\ paleontologia \\ produção de notícia \\ rádio \\ Radiobrás \\ rede de informação em arte \\ São Paulo (2) \\ serviços de informação em arte \\ software \\ terceiro setor
}

